UNIVERSIDADE DE SÃO PAULO

Faculdade de Filosofia, Letras e Ciências Humanas

Núcleo de Estudos das Diversidades, Intolerâncias e Conflitos (Diversitas)

Programa de Pós-graduação Humanidades, Direitos e Outras Legitimidades

Marcelo Fernandes Carnevale

Vizinhança

A palavra como território de coexistência

Tese apresentada ao Programa de PósGraduação interdisciplinar Humanidades, Direitos e Outras Legitimidades, Diversitas, Universidade de São Paulo para obtenção do título de Doutor em Ciências.

(VERSÃO CORRIGIDA)

Orientador Prof. Dr. Sérgio Bairon

São Paulo, 2021 


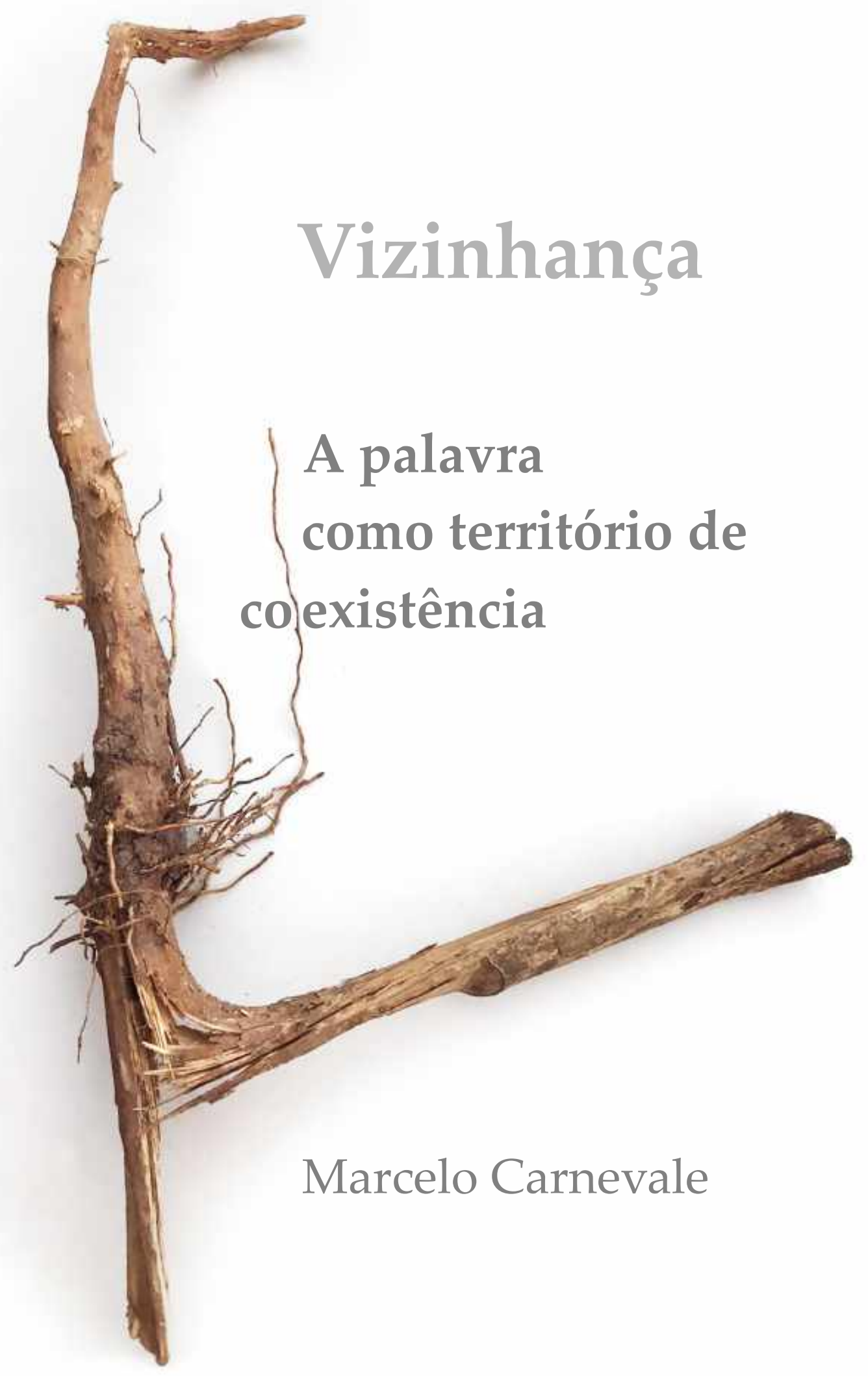


Autorizo a reprodução e divulgação total ou parcial deste trabalho, por qualquer meio convencional ou eletrônico, para fins de estudo e pesquisa, desde que citada a fonte.

Carnevale, Marcelo Fernandes Carnevale

$\mathrm{C} 289 \mathrm{v}$ Vizinhança. A palavra como território de coexistência / Marcelo Fernandes Carnevale Carnevale ; orientador Sérgio Bairon Blanco Sant'Anna Sant'Anna. - São Paulo, 2021. $208 \mathrm{f}$.

Tese (Doutorado)- Programa de Pós-Graduação Humanidades, Direitos e Outras Legitimidades da Universidade de São Paulo. Área de concentração: Humanidades, Direitos e Outras Legitimidades.

1. a palavra como território de coexistência. 2 . palavra. 3. território. 4. coexistência. I. Sant'Anna, Sérgio Bairon Blanco Sant'Anna, orient. II. Título. 


\section{ENTREGA DO EXEMPLAR CORRIGIDO DA DISSERTACÃO/TESE \\ Termo de Ciência e Concordância do (a) orientador (a)}

Nome do (a) aluno (a): Marcelo Fernandes Carnevale

Data da defesa: 03/03/2021

Nome do Prof. (a) orientador (a): Sérgio Bairon Blanco Sant'Anna

Nos termos da legislação vigente, declaro ESTAR CIENTE do conteúdo deste EXEMPLAR CORRIGIDO elaborado em atenção às sugestões dos membros da comissão Julgadora na sessão de defesa do trabalho, manifestando-me plenamente favorável ao seu encaminhamento e publicação no Portal Digital de Teses da USP.

São Paulo, 03/05/2021

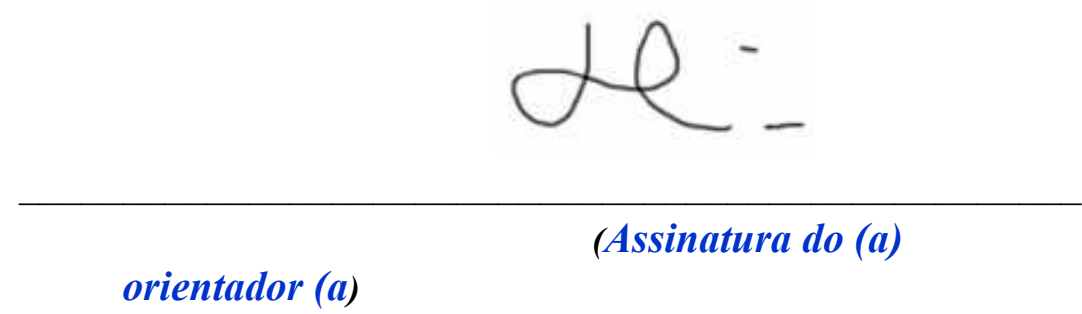


Para Rita Carnevale que muito antes da partida, em 2020, me deu um dicionário Houaiss de presente. 
Pensar

Líquidos brancos

Pensares negros Ácidos disfarçados Correm por vísceras frias

Quem vive fere

Pensando sopra

$\mathrm{O}$ vírus do vazio

Eu mordo

Logo posso

(Sebastião Uchoa Leite, à espreita) 


\section{RESUMO}

A hipótese deste trabalho é pensar vizinhança como escuta da cidade, através de práticas dialógicas que somente a rua, o que se dá no fora, nos permite viver. A partir de um ensaio autoetnográfico sobre a experiência de colocar o corpo nas ruas do bairro da Luz, também conhecido como Cracolândia, Zona Central da cidade de São Paulo, pretendeu-se escapar do sentido comum da palavra vizinhança. Proposta interdisciplinar que repensa a potência do avizinhar, do re-vizinhar e do (re)vizinhar, ao considerar que essas variantes são eixos de relações que fazem do lugar, conhecido como periferia do centro, espaço de múltiplos níveis de (des)semelhança, proximidade e amizade. Trabalho que se insere no conceito da produção partilhada do conhecimento, por criar uma narrativa composta de várias outras narrativas, em torno da visibilidade/invisibilidade que chancelam o tempo de permanência e as condições de vida das pessoas, dos coletivos, dos trabalhadores e de outros agentes, como a própria Universidade de São Paulo, na formação de redes locais. A conclusão é que escutar a cidade para acolher a diversidade é compreender a palavra como um território de coexistência.

Palavras chave: vizinhança, Cracolândia, diversidade, autoetnografia, produção partilhada do conhecimento. 


\begin{abstract}
This work's hypothesis is that the neighborhood is a veritable listening post to the city through dialogical practices that only street life - i.e., what happens out-of-doors - allows us to experience. An autoethnographic essay comprising instances of placing one's body in certain streets of the Luz neighborhood known as Cracolândia (Crackland), in downtown São Paulo, led us to eschew the ordinary meaning of the word neighborhood. This paper is an interdisciplinary proposal to rethink the power of neighboring (adjoining), re-neighboring (rejoining) and (re)neighboring by construing these variants as axes of relationships that make that region - known as downtown's periphery - a space of multiple levels of (dis)similarity, proximity, closeness and friendship. This paper embraces the concept of shared production of knowledge, and creates a narrative composed of numerous other narratives about the visibility/invisibility that attest the length of permanency and the living conditions of individuals, collectives, workers and others agents (such as the University of São Paulo itself) in establishing local networks. The conclusion is that listening to the city - and, thus, welcoming diversity - is to understand the spoken and listened word as a territory of coexistence.
\end{abstract}

Keywords: Neighborhood; Cracolândia (Crackland); Diversity; Autoethnography; Shared Production of knowledge 


\section{AGRADECIMENTOS}

Agradecer para celebrar o encontro, o diálogo, a presença. Gostaria de render graças primeiramente aos que me ensinaram na infância que a vizinhança pode partilhar um Portugal pequeno e uma roda de samba, na mesma ladeira do subúrbio carioca. Devo ao Rio de Janeiro o amor ao coletivo, à rua e à cultura popular.

À vizinhança paulistana, agradeço o acolhimento, a generosidade que me alargou o horizonte e me permitiu experimentar a potência de muitas mudanças. Movimentos que me fizeram desejar a cidade e vivê-la pelo viés que mais me atrai: a diversidade.

O presente trabalho foi realizado com apoio da Coordenação de Aperfeiçoamento de Pessoal de Nível Superior Brasil (CAPES), portanto gostaria de agradecer à CAPES pelo suporte que possibilitou a pesquisa e legitimou o direito à investigação teórica e prática desse trabalho e à Universidade de São Paulo pela minha reinserção na vida acadêmica como parte do meu projeto intelectual.

Das pessoas fundamentais na cidade de São Paulo, gostaria de celebrar a presença de Sérgio Bairon na minha vida. Um orientador amoroso é das sortes que desejo a qualquer pesquisador. Sérgio é um amigo generoso, parceiro que garantiu um passo fundamental na experiência deste doutorado que foi a presença do Diversitas na Cracolândia.

Vivemos como um grupo articulado que tem a atuação de Zilda Iokoi, a quem agradeço pelo exemplo de honestidade intelectual e inquietação existencial. Nossa diva, nossa decana querida, sempre disposta e cúmplice. No universo dos parceiros constantes, gostaria de agradecer ao Luís Galeão e à Marília Librandi que contribuíram com críticas fundamentais à qualificação desse trabalho. Ainda pelo Diversitas, meu agradecimento à Teresa Cristina Teles pela delicadeza com a qual sustenta um entendimento potente sobre a reparação social e pelo profissionalismo que garante a produção do nosso NAP e à Maria Ribeiro, minha parceira querida. E claro, aos integrantes do Diversitas, docentes e discentes, com os quais pude aprender muito nos últimos quatro anos, nas salas de aula, nas atividades, nas reuniões do Conselho de Pós-Graduação, o meu muito obrigado. 
Gostaria de lembrar a sorte de aceitar o convite de Maria Amélia Veras para conhecer o Teatro da Cia. Pessoal do Faroeste, na Luz, em 2014. A ela o meu mais sincero agradecimento. Bem como, o encontro com Marcelo Ribeiro para visitar a Cracolândia, a quem agradeço também.

No território da Luz encontrei muita generosidade, agradeço aos amigos queridos Alberto Silva, Lucas Beda, Paulo Farias e à Veronica Gentilin, e, assim respectivamente, à Casa Florescer, à Cia. Mungunzá e à Cia. Pessoal do Faroeste.

À Carmen Lopes, Maria Angélica Comis e Laura Sahm Shadoir e respectivamente ao Coletivo Tem Sentimento, ao Centro de Convivência É de Lei e ao Coletivo Sem Ternos.

Ao David Guimarães, Fabio Rodrigues dos Santos, à Leona Johvs, Lilian Breschigliaro, ao Paulo Brazyl e Ricardo Paes Carvalho que contribuíram para que eu vivesse melhor a vida na Boca do Lixo.

À Débora de Proença pela produção audiovisual potente, pela presteza e generosidade. À Bel Santos Mayer, Edilamar Galvão, Livia Estrella, Luana Costa, Pedra Homem, ao Cleiton Ferreira (Dentinho), Jaderson Souza, Toni Santos e Vinícius Azevedo, companheires que gentilmente partilharam narrativas para compor o texto.

Ao Felipe Alves de Souza pela parceria sempre cuidadosa e a capa conceitual do trabalho.

À minha família, Ana Jara, Gregorio Carnevale, Lis, Paula Gibim e Vinícius Jara.

Ao apoio da família de amigos, Ana Cláudia Ventura, Angela Maciel Barbosa, Beto Paiva, Carla Boin, Cristina Amendoeira, Heidi Strecker, Ian Marshall Fischer, Jô de Souza, Maria Cláudia Alvarenga, Marilena Senra, Marcos Martins, Nazareth Pinheiro, Pedro Luiz Pereira de Souza, Pedro Paulo Santos, Sandra Amora, Silvia Steinberg e com especial 
reconhecimento ao diálogo, escuta e suporte de Inês Mendonça e Lúcia Maciel Barbosa de Oliveira. Ao Joaquim dos Santos Filho que me apoiou na reta final de maneira surpreendente.

Gostaria de destacar a figura de Alvaro Ancona, meu ex-analista, pessoa solar na minha vida com quem aprendi a rir de mim mesmo, mas sobretudo, com quem contei de forma generosa no momento mais difícil dessa travessia. 


\section{SUMÁRIO}

O sonho elaborado 14

$\underline{\text { Roteiro da tese }}$

Parte 1: A experiência refletida

I. A vizinhança constituída 20

1. A verificação dos endereços 20

2. Comunidades dos iguais 24

3. Ativismo digital 26

4. São Paulo diante dos meus olhos: Luz 30

5. A vizinhança na roda 33

6. As rodas na periferia do centro 42

II. Múltiplos contornos 45

1. O desejo de avizinhar-se 46

2. O lugar nenhum, o lugar de todes 50

3. Acupuntura urbana nas cidades globais 56

Parte 2: Relações abstratas e espaciais de vizinhança 61

III. (Des)semelhança 62

1. No paralelo das calçadas: Cracolândia 62

2. No paralelo das calçadas: microcracolândia 72

3. Tambores da Luz 90 
IV. Proximidade $\quad 98$

1. A universidade à escuta da cidade 98

2. Do que você tem medo? 101

3. Do que a universidade tem medo? 115

4. A cidade educadora 119

5. (In)disciplina no centro da questão 123

V. Descontinuidade, continuidade: comunidade 131

1. A proximidade da roda 131

2. Os trabalhadores da Luz 136

3. A disciplina ativista na prática 142

4. Bocadolixocinema, novos atores 152

Parte 3 - Relações centrais de vizinhança: amizade 165

VI. Vizinhança, avizinhar, (re)vizinhar 166

1. O termo ativo da vizinhança 166

2. Conexões parciais de vizinhança 170

3. Ancestralidade como amizade 173

4. Avizinhamentos extremos 179

5. Considerações finais 188

\begin{tabular}{ll} 
Referências bibliográficas & 192 \\
\hline
\end{tabular}

Anexo - Imagens da Vizinhança da Luz 197 


\section{O sonho elaborado}

Numa manhã, ao despertar de sonhos inquietantes, Marcelo Carnevale deu por si a cama transformado num gigantesco vizinho. Estava deitado sobre o dorso, tão irreconhecível que parecia invisível, e, ao levantar um pouco a cabeça, divisou o arredondado ventre cinza dividido em duros segmentos arqueados, sobre o qual a colcha dificilmente mantinha a posição e estava a ponto de escorregar.

Comparadas com o resto do corpo, as inúmeras pernas, que eram miseravelmente finas, agitavam-se desesperadamente diante de seus olhos, como se corressem para embarcar numa estação lotada de São Paulo. Que me aconteceu? - pensou. Não era um sonho. O quarto, um vulgar quarto humano, apenas bastante acanhado, ali estava, como de costume, entre as quatro paredes que lhe eram familiares. Por cima da mesa, onde estava deitado, exposto e sem muito crédito, um bilhete único. Cartão válido como passe para o metrô, para os ônibus da São Paulo Transporte S.A. e para a Companhia Paulista de Trens Metropolitanos. Restou a ele viver a cidade.

\section{Roteiro da tese}

Essa tese é um convite à reflexão sobre a metamorfose que reconfigurou o estar na cidade ao promover uma imprecisão nas bordas que separam a casa da rua, o conhecido do estranho, o corpo do espaço que ele ocupa e que possibilitou fazer da palavra um território de coexistência. E, a partir dessa condição, o que podemos experimentar ao relacionarmo-nos com toda sorte de estados de intensidade presentes. A ideia é tentar compreender o como e o porquê 
do avizinhar-se das pessoas, dos lugares e das coisas no ambiente urbano, transformou-se numa das experiências mais potentes do bem viver.

A estrutura dessa pesquisa se apoia em três partes: a experiência refletida; com um desenho figurativo, concreto, das situações de vizinhança; relações abstratas e espaciais de vizinhança, um desdobramento do termo pelo viés conceitual e experimental da vida na Luz, região central da cidade de São Paulo; e relações centrais de vizinhança: amizade, uma liberação e reinvenção de sentidos pelo afeto de (re)vizinhar-se.

A memória da palavra vizinhança como algo banal e de contornos pouco vibrantes tinha a ver com a reprodução de um padrão na paisagem dos sentidos. Transformá-la em palavra aliada, nessa jornada, foi possível a partir de uma constatação: a falta de vivenciá-la como algo dado, algo posto, na megalópole que dela também se esquece.

São Paulo estimulou o reencontro, a reescritura e, portanto, uma nova literatura sobre vizinhança, que se apoia num roteiro criado a partir do quadro sinóptico de categorias do Dicionário analógico da língua portuguesa (ou de ideias afins), mas sobretudo na experiência urbana que me levou a compreendê-la como micropolítica, como comunicação e comunidade.

Esse estranhamento ganhou eco e encontrou voz na autoetnografia e na interdisciplinaridade. Produziu uma narrativa na qual ecoam conceitos da antropologia urbana, da filosofia, da química, da literatura, da medicina social, da estética, da pedagogia, da física, do direito, da política universitária e da produção partilhada do conhecimento, os quais me revelaram a memória oral, a performance, o teatro, a escuta, a terapia comunitária, a conversa de botequim, a poesia, as texturas sonoras, as imagens, o cinema, a narrativa composta de várias narrativas e a rua como palco de acontecimentos cruciais para essa experiência.

A assimilação da palavra vizinhança foi se ampliando primeiramente pela arquitetura de sentidos da própria palavra e pelos desenhos revelados infinitas vezes nas quais ela voltou a ser pronunciada, vivenciada e reinventada.

Apoiado na lógica do dicionário que busca entre palavras análogas um tipo de correlação, analisando um conjunto delas semanticamente agrupadas com maior ou menor grau de proximidade e exatidão, coube, também, sobrepor aos recursos que ampliam e muito o uso da palavra os "contextos conceituais da existência real - concreta e abstrata, física e espiritual, 
objetiva e subjetiva - para que a partir deles, em subramificações que facilitam sua localização, possam ser encontrados os termos que melhor os expressem". ${ }^{1}$

O recorte da pesquisa se apropria do significado de vizinhança a partir de algum dos conjuntos de sentidos do quadro sinóptico: relação abstrata parcial, dimensão geral de espaço e dimensão central de afeições simpáticas sociais.

Num paralelo com Gregor Samsa, a mudança no conjunto de sentidos de vizinhança se destaca em três planos:

1. Vislumbre de um outro estado de coisa ao experimentar uma reação no contexto sem ser totalmente consumido, durante o processo. Rompimento com aspectos de semelhança por identificação com um significado já dado para explorar a multiplicidade não totalizadora ao criar nós que se interligam pela (des)semelhança e promovem um deslocamento, uma deriva por estados de intensidade que nada mais garantem do que o desejo inequívoco de tornar-se com, ser com, ser qualquer um, avizinhar-se para partilhar a partilha.

2. A sobreposição com o que é estranho e pelo avizinhar-se possibilita experimentar outros tipos de aproximação, diálogos, presença, ao relacionar-se num moto-contínuo como única possibilidade de comunicação.

3. A experiência surpreendente da descontinuidade que expressa afetos de metamorfose e revela-se potente na multiplicidade de algo que é menos que um, que surge da subtração e que encontra nas novas composições celulares novas espécies companheiras.

Seriam assim relações abstratas parciais de (des)semelhança, num escopo ampliado das analogias que afloram no roteiro estruturado a partir do conjunto de sentidos presentes nas vizinhanças de "vizinhança" cartografadas no próprio dicionário, tais como: analogia, similaridade, similitude, imitação, longes, parecença, vislumbre, consanguinidade, afinidade, conformidade, parentesco, relação, proporcionalidade, isomerismo, aproximação, paralelismo,

\footnotetext{
${ }^{1}$ AZEVEDO, Francisco F. dos S., Dicionário analógico da língua portuguesa: ideias afins/thesaurus, 2. ed. Rio de Janeiro: Lexikon, 2010, p.:ix.
} 
conexão, aliança, paridade, parilidade, vizindade, propinquidade, reminiscência, polimetria, polimerismo, paranomásia, aliteração, rima, trocadilho, calembur. ${ }^{2}$

Pela dimensão geral de espaço por proximidade que se desdobra em: contato, confinidade, beira, vicinalidade, vizindário, justaposição, imediação, propinquidade, entorno, toque, raia, fronteira, limite 233; contérmino, aposição, preposição, sobreposição. ${ }^{3}$

E, ainda, pela dimensão central das afeições simpáticas sociais, como: amigo, íntimo/afim/do peito/da alma/de fé/de taça/de copo/de todas as horas/de verdade; íntimo, companheiro, inseparável, irmão, conhecido, alter ego, fidus Achates ( = 'amigo confiável'), amicus usque ad aras confidente (= 'amigo ao extremo', 'totalmente confiável' [+-]), fac-totum, depositário, amigão ou amigona, amigalhão, amigalhaço, protetor, ilhargas, fautor; fautriz, patrono, conselheiro, colador, -colator; mecenas, anjo tutelar, boa estrela, advogado (fig), partidário, correligionário, simpatizante, devoto, paniguado ou apaniguado, adepto, aliado (auxiliar). ${ }^{4}$

Abaixo apresento, a partir do roteiro do dicionário, o esquema resumido e destacado dos sentidos de vizinhança que escolhi para nortear seu uso e reflexão na tese.

Classe I. Relações Abstratas

Divisão II. Relação

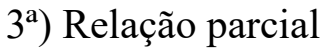

17. Semelhança

(Des)semelhança

Classe II. Espaço

Divisão Dimensões

$1^{\text {a) }}$ Em geral

\section{Proximidade}

\footnotetext{
${ }^{2}$ Id., ibid., p. 7.

${ }^{3}$ Id., ibid., p. 79.

${ }^{4}$ Id., ibid., p. 428.
} 
$3^{\mathrm{a})}$ Central

I. Em geral

227. Circunjacência

Classe VI. Afeições

Divisão III. Afeições simpáticas

$1^{\text {a) }}$ Sociais

890. Amigo ${ }^{5}$

(Des)semelhança, proximidade e amizade são as conexões que sustentam os desdobramentos da palavra nessa pesquisa e que pela vizinhança na cidade de São Paulo, especialmente na região da Luz, permitiram um tipo de construção da vida que "está muito mais no poder de fatos que de convicções", como assinala Walter Benjamin, logo nas primeiras linhas de Rua de mão única.

${ }^{5}$ Id., ibid., p. XIV. 
Parte I: A experiência refletida 


\section{A VIZINHANÇA CONSTITUÍDA}

\section{A VERIFICAÇÃO DOS ENDEREÇOS}

A palavra vizinhança tinha o significado cristalizado, no meu entendimento de mundo, de uma situação restrita ao que estava circunscrito ao meu entorno, aos moradores das casas e apartamentos próximos ao meu domicílio. Situação herdada por um aspecto fatalista da coincidência de endereços, evento comum nos centros urbanos no qual a presença espontânea do outro quase sempre se traduz como um problema a ser evitado.

Vizinhança como sinal de conflitos por disputa de interesses, sem nenhuma relação possível com a tecnologia comunitária das regiões periféricas nas quais, na maioria das vezes, brotam tipos de arranjo, métodos e processos como táticas para suprir a ausência do poder público. Locais de pobreza onde a rua é sinônimo de encontro, diversão e fonte de renda, com seus pequenos comércios misturados aos espaços de moradia, marcando assim uma ocupação mais caótica do território, mas com outro nível de solidariedade.

Minha memória recente sobre vizinhança vem das áreas integradas da classe média alta, com um adensamento demográfico provocado pelo mercado imobiliário e o paradoxal esvaziamento das ruas. Realidade que aparece na proliferação dos condomínios fechados por muros altíssimos, sem nenhuma zona de transição para o passeio público.

São prédios, setores de casas, todos reféns das empresas de segurança que tiram proveito da perda de interesse dos moradores pela convivência com a singularidade, com a instabilidade da via pública, com o que é comum a todos independente da origem de cada um. Apostam na homogeneidade segregadora, pautada pelo privado, numa tentativa de garantir a tranquilidade e a qualidade de vida para quem pode e acredita nesse tipo de escolha.

Paradoxalmente isolados em bolhas, dentro do centro expandido da maior capital da América Latina, perdem a chance de experimentar um dos melhores elementos constitutivos do cosmopolitismo: a convivência com a diversidade.

Podemos recorrer a Boaventura do Santos para pensar nesse tipo de miopia, "uma alienação para que muito do que não existe em nossa realidade seja produzido como não existente e, por isso, a armadilha para nós seria reduzir a realidade ao que existe. Selaríamos, 
assim, de imediato, o compartilhamento dessa racionalidade preguiçosa, que realmente produz como ausente muita realidade que poderia estar presente". ${ }^{6} \mathrm{O}$ desenho dessa situação flagrante me faz lembrar um certo tipo de inocência tão bem retratada no poema Inocentes do Leblon, de Carlos Drummond de Andrade:

\author{
Os inocentes do Leblon \\ Não viram o navio entrar. \\ Trouxe bailarinas? \\ trouxe imigrantes? \\ trouxe um grama de rádio? \\ Os inocentes, definitivamente inocentes, tudo ignoram, \\ mas a areia é quente, e há um óleo suave \\ que eles passam nas costas, e esquecem. ${ }^{7}$
}

Hoje, São Paulo é um exemplo da dinâmica metropolitana que tem a especulação imobiliária como o fiel da balança na regulação da convivência citadina, mercado dos mais dinâmicos que não pára de produzir lançamentos em várias zonas da cidade. Pude testemunhar essa plena atividade como morador da zona oeste da capital paulista por catorze anos. ${ }^{8}$

O apelo é para acreditar que o que escapa ao sonho do condomínio protegido é melhor ignorar. Portanto, o conteúdo que ecoa sobre o tema vizinhança, na Internet, não poderia ser diferente, está circunscrito e repete enfadonhamente a perspectiva que aponta para a prevenção de conflito, as condutas de segurança e as regras de convivência condominial. Uma narrativa que tem como objetivo atingir algum nível de neutralidade, de apaziguamento, e que aposta na manutenção de um certo tipo de inocência alienada refratária ao que é diferente.

Destaco dois exemplos que reforçam o uso limitado da palavra vizinhança pelas estratégias de marketing alinhadas aos interesses das próprias incorporadoras do setor

${ }^{6}$ SANTOS, Boaventura de Sousa. Renovar a teoria crítica e reinventar a emancipação social. São Paulo: Boitempo, 2007, p. 28.

${ }^{7}$ ANDRADE, Carlos Drummond de. Sentimento do Mundo. São Paulo: Cia das Letras, 2012, p.28

${ }^{8}$ No período de 2002 a 2014, segundo dados da Embraesp, ocorreram 3.442 lançamentos residenciais verticais e 287 lançamentos comerciais verticais no município de São Paulo. Na Região Oeste foram 914 residenciais e 112 comerciais, sendo na Subprefeitura de Pinheiros, 400 residenciais e 72 comerciais, dos quais 196 e 41 , respectivamente, no distrito de Itaim-Bibi. 
imobiliário. "Dicas para um bom relacionamento com a vizinhança" foi o primeiro tema que surgiu quando fiz a busca da palavra vizinhança na Internet. No ambiente de busca do Google, após uma sequência de verbetes com definições da palavra, em diferentes dicionários, o conteúdo abaixo ganha destaque.

Figura 1 - Página chamada "Pronto para mudar" do site da Construtora Santa Angela, que atua na região de Jundiaí, no interior de São Paulo. O título "Já pra casa", típico do estilo publicitário, remete ao duplo sentido da pronta entrega e da ordem de recolhimento. Um toque de recolher.

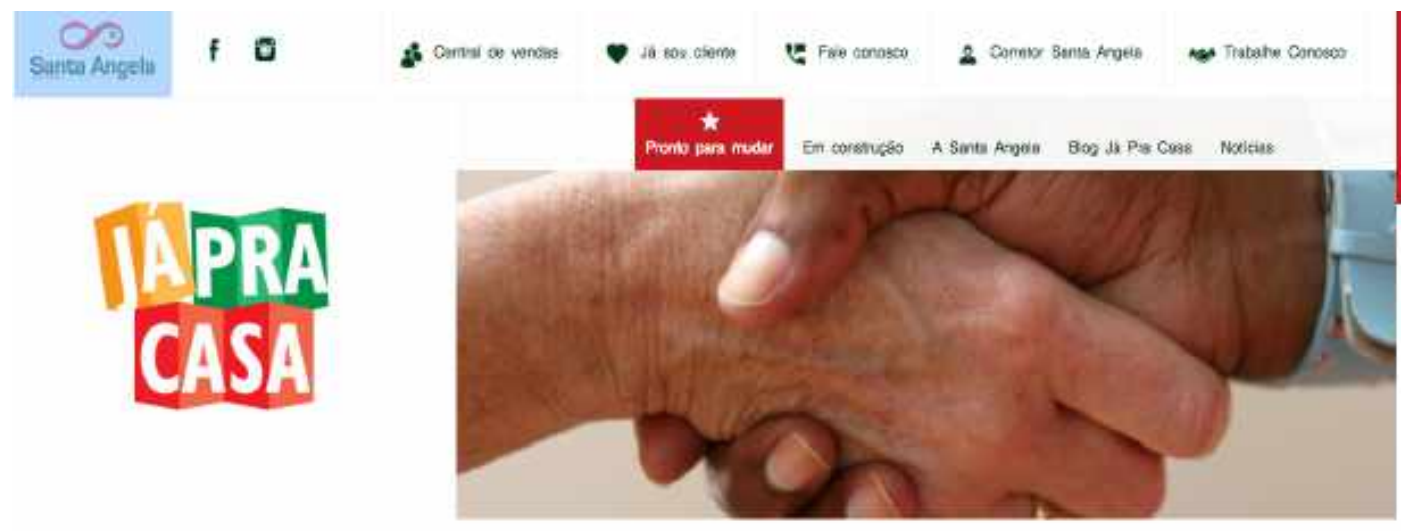

\section{Dicas para um bom relacionamento com a vizinhança}

Uma case ou epertamenso novo envolve vários desaflos: escolhe,

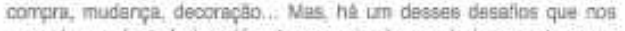
eguardarn apde vido iseo ja estar arganizado: o relacionamento corn \# vizirhenca. As pesecas que motan pidximios a nds (e provavahernte einda per multos anos) tem tudo para se tornarem parte da familia mas sinda por mulitos anos) tem tudo para se tornarem parte da familia mias empecithes nesta ethega de crias tapos com esiranhes Panserdo em
Última noticia

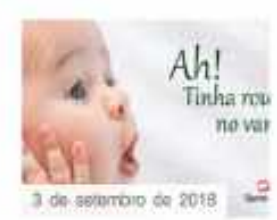


Figura 2 - Página do site da construtora VITACON apresentando as normas adotadas no período de construção dos empreendimentos. O título "Portal da vizinhança" é monotemático: limita-se a expor o impacto das obras na cidade e a oferecer o contato do Programa de Silêncio Urbano - PSIU.

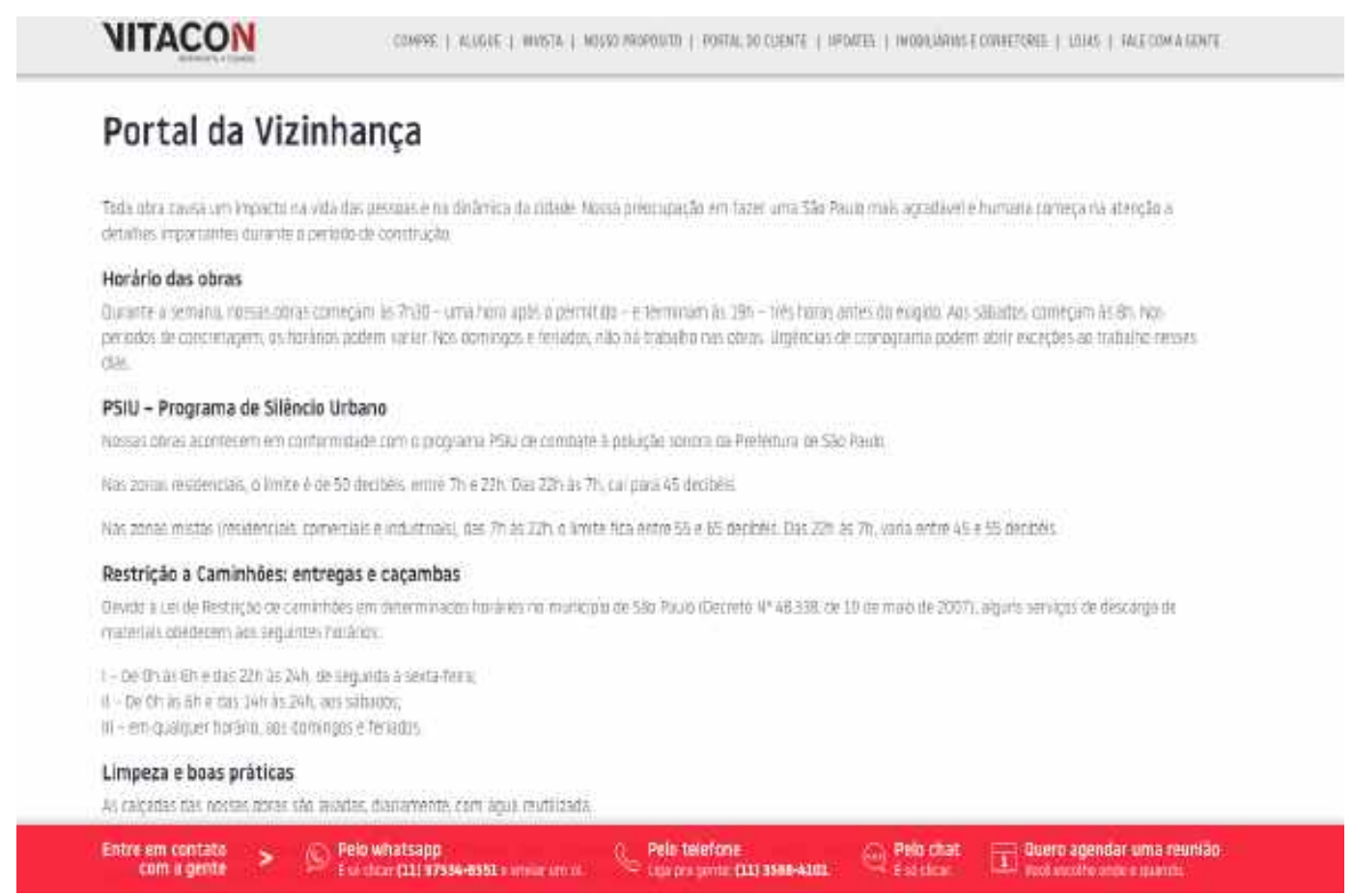

A possibilidade de ampliação do conceito de vizinhança para além desse pensamento que privilegia o recolhimento egoísta - fazendo uso de uma observação feita por Michael Löwy ${ }^{9}$ quando ele reflete sobre grupos sociais nos dias de hoje - tem a ver com a experiência de buscar outras maneiras de inserção na própria cidade.

Essa procura de outros sentidos para compreender vizinhança ressoou como um resgate de uma palavra carregada da ideia de um individualismo exacerbado e reduzida às situações e imagens as mais caricatas da convivência coletiva, como a simpatia forçada quando no

\footnotetext{
${ }^{9}$ Michel Löwy, em Revolta e melancolia: o romantismo na contracorrente da modernidade (2015), pensa o recolhimento egoísta no indivíduo a partir da citação de Gustavo Gutiérrez, em A força histórica dos pobres (1981): "O individualismo é o aspecto mais importante da ideologia moderna e da sociedade burguesa. Para a mentalidade moderna, o homem é um começo absoluto, um centro autônomo de decisões. A iniciativa e o interesse individuais constituem o ponto de partida e o motor da atividade econômica".
} 
empréstimo de uma xícara de açúcar (lembrança mais evocada pelas pessoas, quando o tema vizinhança vem à tona) ou a patrulha raivosa de um vizinho mal humorado que reivindica a diminuição do som da festa. Clichês que fazem da vizinhança uma palavra "morta de cansaço", pegando emprestado a expressão inventada por Agamben.

O desdobramento do significado de vizinhança se deu a partir de um desejo de estar plenamente em São Paulo e fazer da palavra território de coexistência. Ocupar o espaço público, dialogar, escutar a cidade e seus habitantes.

\section{COMUNIDADE DOS IGUAIS}

A participação nas reuniões mensais, entre 2013 e 2015, do Conselho Municipal do Meio Ambiente e Desenvolvimento Sustentável - CADES, da Secretaria do Verde e Meio Ambiente da Prefeitura de São Paulo, na condição de conselheiro suplente da subprefeitura de Pinheiros, ${ }^{10}$ proporcionou-me a atuação em uma série de debates sobre a coisa pública.

A sucessão de encontros produziu um efeito pedagógico na articulação das lideranças de grupos sintonizados com os mesmos objetos de desejo: exercitar o trabalho voluntário, zelar pelo seu pedaço, criar modelos alternativos de produção, entre outras ações.

Michel Löwy chama a atenção para o fato de que essa redescoberta da dimensão comunitária tem origem na Teologia da Libertação, no começo dos anos 1960, como expressão cultural de um vasto movimento social na América Latina. Simultâneo é o surgimento das

\footnotetext{
${ }^{10}$ Localizada no vetor oeste da cidade, a Subprefeitura Pinheiros tem área de cerca de 3.170 ha distribuídos por quatro distritos: Alto de Pinheiros, Jardim Paulista, Itaim-Bibi e Pinheiros. A várzea do Rio Pinheiros está situada na cota de 721 metros de altitude e é de uso predominantemente residencial, de médio a alto padrão. Os distritos de Alto de Pinheiros e Pinheiros estendem-se da várzea do Rio Pinheiros até o espigão formado pelas avenidas Cerro Corá, Heitor Penteado e Dr. Arnaldo. O Distrito do Jardim Paulista ocupa as áreas de encosta do espigão da Avenida Paulista, com cotas variando de 818 metros até a meia encosta, de 744 metros. Nos anos 1970, com a abertura da Avenida Brigadeiro Faria Lima e seu prolongamento nos anos 1990, que impulsionou as transformações da região, firmou-se como um dos principais centros econômicos da cidade. É atendida por duas linhas de metrô, uma linha de trem e dois corredores de ônibus. Apesar disso, $60 \%$ das viagens diárias de seus habitantes são feitas pelo modo individual. É cortada pelo trânsito de passagem do sistema radiocêntrico da cidade, provocando conflitos de uso e com o transporte coletivo. Cerca de 34\% de seu território é ocupado por Zonas Exclusivamente Residenciais (ZER). O uso residencial responde por $61 \%$ de sua área construída e as atividades comerciais e de serviços por 31\%. Dados coletados no Caderno de Propostas dos Planos Regionais das Subprefeituras Quadro Analíticos Pinheiros de 2016.
} 
comunidades eclesiais de base que, sem entrarmos no mérito da eficácia como projeto, ecoam até os dias de hoje. Foram experiências marcantes na tentativa de suprir necessidades nas áreas mais carentes e na luta por pautas de grandes dimensões, como a destruição da floresta amazônica e a proteção do etnocídio nas comunidades indígenas.

Muito distante dessas ambições, o que se mostrou realidade em minha participação das reuniões do Cades da Subprefeitura de Pinheiros, foi o tímido resgate da convivência em grupo para discussões de uma pauta variada, numa zona privilegiada da cidade. De alguma forma experimentávamos a surpresa diante da nossa própria ignorância na lida com as demandas e seus encaminhamentos na máquina municipal, e a frustração, no meu caso, de não encontrar diferentes perfis socioeconômicos de moradores.

As reuniões públicas, apesar de divulgadas nos canais de comunicação da subprefeitura, sempre foram muito pouco frequentadas pela população. Entre conselheiros e representantes do poder municipal manteve-se uma média nunca superior a vinte participantes, numa área cujo censo demográfico de 2010 indicou a presença de 289.743 habitantes.

Um flagrante da ausência de interesse da população da região, se constatarmos que todos os distritos da Subprefeitura de Pinheiros apresentam um Índice Paulista de Vulnerabilidade Social (IPVS) baixo ou igual a zero e o Índice de Desenvolvimento Humano (IDH) da ONU, que tem como pilares: saúde, educação e renda, $(0,94)$ igual ao da Subprefeitura da Vila Mariana - 0,94 -, sendo os dois maiores IDHs do município. ${ }^{11}$

O grupo do Cades-Pinheiros reunia um conjunto de interesses: o ativismo das hortas urbanas, caracterizadas pelo cultivo de alimentos produzidos em praças, canteiros, coberturas de prédios públicos; o ciclismo como alternativa ao meio de transporte na cidade; a reformulação das calçadas para os pedestres, entre outros. O perfil dos conselheiros era formado por donas de casa, comerciantes, aposentados e profissionais liberais, que privilegiavam aspectos sobre segurança, saúde, zeladoria do verde e ocupação do espaço público para o lazer.

Uma amostra de homogeneidade representada por um grupo de brancos escolarizados da classe média alta da zona oeste, interessados no acompanhamento da gestão do subprefeito

\footnotetext{
${ }^{11}$ Dados coletados no Caderno de Propostas dos Planos Regionais das Subprefeituras - Quadro Analíticos de Pinheiros, de 2016.
} 
na região. Em muitos casos, a partir de iniciativas individuais, como bem aponta Michel Löwy citando o teólogo americano Harvey Cox:

Como observa muito pertinentemente Harvey Cox, essas comunidades contêm um aspecto de escolha individual tipicamente moderno, o que produz novas formas de solidariedade que nada têm a ver com as estruturas arcaicas tribais ou vilarejas. Por esse aspecto moderno, podemos considerá-las agrupamentos voluntários utópicos, no sentido que Jean Séguy dá a esse conceito, quer dizer, agrupamentos dos quais os membros participam de livre e espontânea vontade e que visam (implícita ou explicitamente) mudar - de maneira ao menos optativamente radical - os sistemas sociais globais existentes. ${ }^{12}$

A experiência como conselheiro do Cades, sem dúvida, revelou-me a fragilidade da minha noção de cidadania, o meu distanciamento da vida política, próximo do que observa Hanna Arendt ao questionar "como o homem, se tem que viver na polis, pode viver fora da política". ${ }^{13}$ Apontou, ainda, a direção que exigia meu corpo nas ruas da cidade para seguir ao encontro de gente de todo tipo. Dessa maneira, eu poderia me livrar do preconceito e do prejulgamento do que a ideia de vizinhança significava até aquele momento, para me aproximar espontaneamente de tudo o que a cidade e seus habitantes podiam me apresentar.

\section{ATIVISMO DIGITAL}

Considero como primeira ação que caracteriza esse desejo de mudança a criação do blog A vizinhança. O projeto foi idealizado para compartilhar vestígios do cotidiano que atravessam

\footnotetext{
${ }^{12}$ LÖWY, Michel e SAYRE, Robert. Revolta e melancolia: o romantismo na contracorrente da modernidade. São Paulo: Boitempo, 2015. p. 218.

${ }^{13}$ Hannah Arendt chama a atenção para o fato de o início da tradição filosófica ocidental, com Platão e Aristóteles, ocorrer quando a vida política grega já se aproximava do seu fim; momento no qual surge o problema de "como o homem, se tem que viver numa polis, pode viver fora da política. Esse problema, que por vezes apresenta uma estranha semelhança com a nossa própria época, muito rapidamente se converteu na questão de como é possível viver sem pertencer a nenhuma comunidade politicamente organizada (...)". ARENDT, Hannah. A promessa da política. Rio Janeiro: DIFEL, 2008, p. 46.
} 
diariamente os lugares nas cidades. O espaço serviu para a produção de uma série de pequenas crônicas a partir da minha incursão pelas ruas de alguns lugares, nos quais São Paulo prevaleceu no conjunto dos textos publicados no período de atividade do blog, 2013-2017.

Figura 3 - Nome do blog.

\section{a vizinhança \\ empresa.bairro.aldeia.cidade}

O título do blog assumiu uma provocação ao considerar empresa, bairro, aldeia e cidade a mesma vizinhança. Um embaralhamento de códigos, como pensou Deleuze, sobre os grandes instrumentos de codificação, enumerados como três principais: a lei, o contrato e a instituição. ${ }^{14}$ Nesse desejo de avizinhar-se sem contratos ou verificações, evocando todo o tipo de gente presente no território, com suas memórias, hábitos e costumes, muito contribuiu a experiência marcante de ter ido anonimamente às ruas, em junho de 2013. ${ }^{15}$ Uma São Paulo irreconhecível foi tomada por manifestantes que cruzaram em marcha a partir da área da subprefeitura de Pinheiros: Largo da Batata, av. Faria Lima, av. Cidade Jardim até alcançar o ícone da potência neoliberal na cidade - a Ponte Octávio Frias de Oliveira, mais conhecida como a ponte estaiada da Marginal Pinheiros.

As mobilizações multiplicaram-se pelas principais capitais e, até os dias de hoje, são interpretadas, analisadas, como um marco na história recente do país. Para mim ficou o registro da primeira grande escuta da cidade, palavras que ecoam na linha do tempo através do

\footnotetext{
${ }^{14}$ DELEUZE, Gilles. y GUATTARI Félix. El Anti Edipo Capitalismo y Esquizofrenia. Traducción de Francisco Moge. Barcelona: Paidós, p: 232.

15 "O Brasil foi às ruas em junho de 2013", in Acervo O Globo, publicado em 15/05/2014. O mês de junho entrou para história com protestos convocados por redes sociais, sem comando de partidos, reunindo mais de 1,5 milhão de pessoas no país inteiro.
} 
chamamento permanente: "Vem, vem, vem pra rua, vem!”. Potência de um aforismo por ser o pensamento afetado pelo que vem de fora, nas várias interpretações e apropriamentos.

Evento que ultrapassou e muito a causa inicial do protesto pelo aumento da tarifa do transporte público, e criou a condição de encontros improváveis no anonimato das ruas; permitiu, ainda, que a palavra vizinhança assumisse a categoria de nome próprio, condição na qual menos importante do que significante ou significado está uma designação de intensidade.

Figura 4 - Cabeçalho do blog composto de imagens captadas especialmente para as pautas.

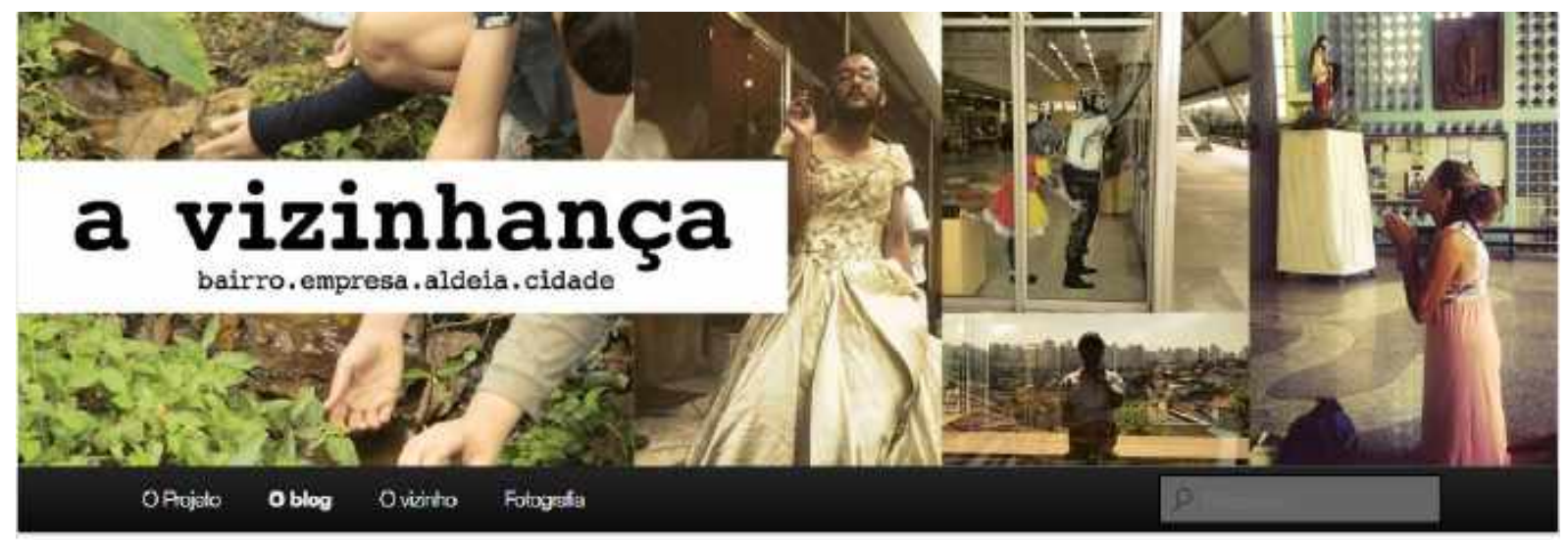

A edição das fotos do cabeçalho, feitas depois de algum tempo de produção dos primeiros conteúdos, mais do que o próprio texto de apresentação, registra melhor a proposta do blog. Entretanto, ambos, textos e imagens, apostam na diversidade de pessoas e situações como estratégia para reforçar um nível de paralelismo mais evidente que assegure algum grau de proximidade e que permita um tipo de empatia por sermos todos humanos. Abaixo segue o texto de apresentação do blog:

Um carro engarrafa no eixinho ao tentar entrar na 103 Sul, em Brasília. No Brooklyn, em Nova Iorque, três jovens italianos recém-chegados cochilam esperando o trem da linha $\mathrm{C}$ (a linha micada do metrô).

A motorista brasiliense quer que o filho cresça e perceba a importância do mundo sustentável. Os italianos querem fugir da crise e encontrar oportunidades de trabalho. 
Sustentabilidade, juventude, tudo isso também interessa ao índio da Vila de Anã, no Pará - preocupado em como ajudar a comunidade a se fortalecer e não perder os adolescentes para os apelos da cidade grande: Santarém.

$\mathrm{Na}$ av. Luís Carlos Berrini, no Brooklin Novo, em São Paulo, o CEO de uma empresa percebe que o modelo de hierarquia não retém mais talentos. Preocupado com a crise, não sabe como atender à pressão por uma agenda sustentável. Intimamente quer dialogar melhor com a nova geração.

São todos nossos vizinhos, porque nos identificamos com o que é demasiado humano.

Bem-vindo à comunidade!

A jornada de entrevistas, textos sobre os lugares e a assimilação do que se apresentava diante da câmera permitiram alguma compreensão do mundo "tal qual ele se me revela" com um nível de complexidade maior e menos idealizado, simplesmente como expressão de todas as dificuldades de entendimento, como nos propõe Hanna Arendt ao supor que o mundo se revela de maneira diferente aos homens. ${ }^{16}$

\footnotetext{
${ }^{16}$ Para Sócrates, assim como para seus concidadãos, a doxa era a formulação em discurso de dokei moi, ou seja, "aquilo que me pareceu". O objeto dessa doxa não era o que Aristóteles chamava de eikos, o provável, as muitas verisimilias (por oposição à unum verum, verdade única, por um lado, e às falsa infinita, infinitas inverdades, por outro), mas a compreensão do mundo "tal como ele se me revela". Não era, portanto, fantasia subjetiva e arbitrariedade, mas tampouco algo absoluto e válido para todos. A suposição é a de que o mundo se revela de maneira diferente aos homens segundo a posição ocupada por cada um; e a a "mesmice" do mundo, seu caráter comum (koinon, diriam os gregos, 'comum a todos') ou "objetividade" (como diríamos desde o ponto de vista subjetivo da filosofia moderna), reside no fato de que o mesmo mundo se revela a todos e, apesar de todas as diferenças entre os homens e suas posições) - "tanto eu quanto você somos humanos". ARENDT, Hannah. $A$ promessa da política. Rio Janeiro: Difel, 2008, p. 56.
} 


\section{SÃO PAULO DIANTE DOS MEUS OLHOS: A LUZ}

No blog registrei a primeira incursão na região da Luz, em 2014, o objetivo foi a produção do perfil de Paulo Farias, diretor do Teatro da Cia. Pessoal do Faroeste, localizado na Rua do Triunfo, 301-305, no coração da "Boca do Lixo".

A criação como trunfo

Na saída do metrô Luz, em plena Cracolândia, confirmo a direção da Rua do Triunfo com três guardas que parecem não entender o que falo. Resgato um papel do bolso com o mapa da área. Um deles, o mais solícito, assume uma eficiência de aluno em arguição. Sou eu quem dou a dica. Os policiais gaguejam diante do lugar.

Minha opção é seguir, mesmo sabendo que poderia não ser poupado - eu e o guarda somos atores inseguros. A plateia é sinistra, bruta, sem códigos universais.

Tento me encaixar na movimentação por mais que saiba que o muito do que não vejo me espreita e muito do que não sei me atrai. Lá estou, pleno faroeste, num tiroteio de sensações no qual o desejo nem sempre é o mocinho e o que me excita nem sempre é bandido.

Acionei a campainha, algo patético diante da boca escancarada que me oferecia uma escada íngreme. Cheguei num patamar intermediário para encontrar o diretor teatral Paulo Faria.

Ele me recebeu com uma gentileza discreta, sabe que o espetáculo lá fora acontece o tempo todo e que o público do Pessoal do Faroeste é formado por quem procura uma cena mais criativa na cidade.

Paulo faz da própria dramaturgia um ponto na Rua do Triunfo, 301, na famosa e esquecida "Boca do Lixo". Há dois anos, o sobrado funciona como teatro para o Pessoal do Faroeste, companhia que existe há dezesseis anos.

No térreo, o bar junto com a venda de produtos da Daspu, insere o teatro na dinâmica do comércio. Essa estratégia minimiza a linha que separa o dentro do fora, possibilita que alguém se abrigue para tomar cerveja e olhar o drama que espalha miséria, delírio e abandono entre os enjeitados que circulam no quadrilátero da Boca.

Para quem está cansado desse clichê, o Pessoal do Faroeste faz outro convite: assistir aos espetáculos que encenam textos teatrais pautados pela arqueologia da própria área. São camadas que se sobrepõem em décadas de abandono, reveladas em histórias incríveis das cercanias da Luz.

Quadrilátero do Pecado, Polígono do Amor ou Boca do Lixo 
O caderno com o texto da peça Homem não entra, produção de 2013, explica que na década de 1950 o governador Lucas Nogueira Gracez e o prefeito recém-eleito Jânio Quadros decretaram o fim da zona livre do Bom Retiro. Desalojadas, as prostitutas passaram a ocupar os hotéis baratos próximos das estações ferroviárias Júlio Prestes e Luz.

O traçado da área tem início da Rua Mauá, a poucos metros da estação da Luz, prossegue pela Rua dos Protestantes, passando pela Rua do Triunfo e chegando na Avenida Ipiranga. Continua na famosa esquina com a São João e segue por essa avenida até encontrar a Avenida Duque de Caxias. O desenho se fecha novamente na Rua Mauá.

Atraídos pelos baixos valores, no final da década de 1950 e meados da década de 1960, a maior parte das distribuidoras de filmes tinha escritório na região, antigo pólo de produção de cinema que lá funcionou até 1990.

A mesma cena com novos atores

Paulo conta que chegou na Boca do Lixo por conta dos predinhos que poderiam virar teatro. Para além do baixo valor imobiliário da região, existe a afinidade que une a dramaturgia do diretor com o cinema. Ele admite que os textos de autoria própria são muito cinematográficos como o Cine Camaleão: Boca do Lixo, montagem de 2012 que homenageou o ator, cineasta e produtor David Cardoso, o rei da pornochanchada.

O diretor revela que a aproximação com estudiosos e profissionais do cinema ajudou a reavivar a memória do lugar. Em duas décadas, o polo produziu centenas de dramas, filmes de faroeste, terror, aventuras, policiais e filmes com temas históricos, como o clássico Independência ou Morte", de 1972, com Tarcísio Meira no papel de d. Pedro I e Glória Menezes como Marquesa de Santos, em um lançamento da Cinedistri.

Muitas gerações foram influenciadas pelo que se passava naquele pedaço. Cinema que exibia uma São Paulo criativa e marginal, mais integrada na sua diversidade do que a cidade atual.

\section{Má educação}

São nomes que me recordam os souvernirs da infância (recheada de calendários eróticos, pilhas de revistas e filmes pornô): Sônia Braga, Vera Fischer, Matilde Mastrangi, Nicole Puzzi, Nuno Leal Maia, Claudio Marzo e, obviamente, David Cardoso.

A Rua do Triunfo me devolve uma São Paulo imaginária, mais cosmopolita e menos engarrafada. Representada pela ação da câmera com planos e roteiros despretensiosos, mas que detonaram meu desejo de conhecer a metrópole cinza e interessante. Como disse Paulo Faria, uma cidade mais marginal, uma cidade mais humana. Eu diria, sobretudo, experimental. 
Quem se limita a acreditar que nessa área encontramos apenas miséria, não olha para o lugar. Reencontrei alguns cenários marcantes, reconheci o que o vento soprou na lembrança e me dei conta de que a Boca é coisa nossa. A lição eu sei de cor.

Figura 5 - A Boca do Lixo ou o Quadrilátero do pecado

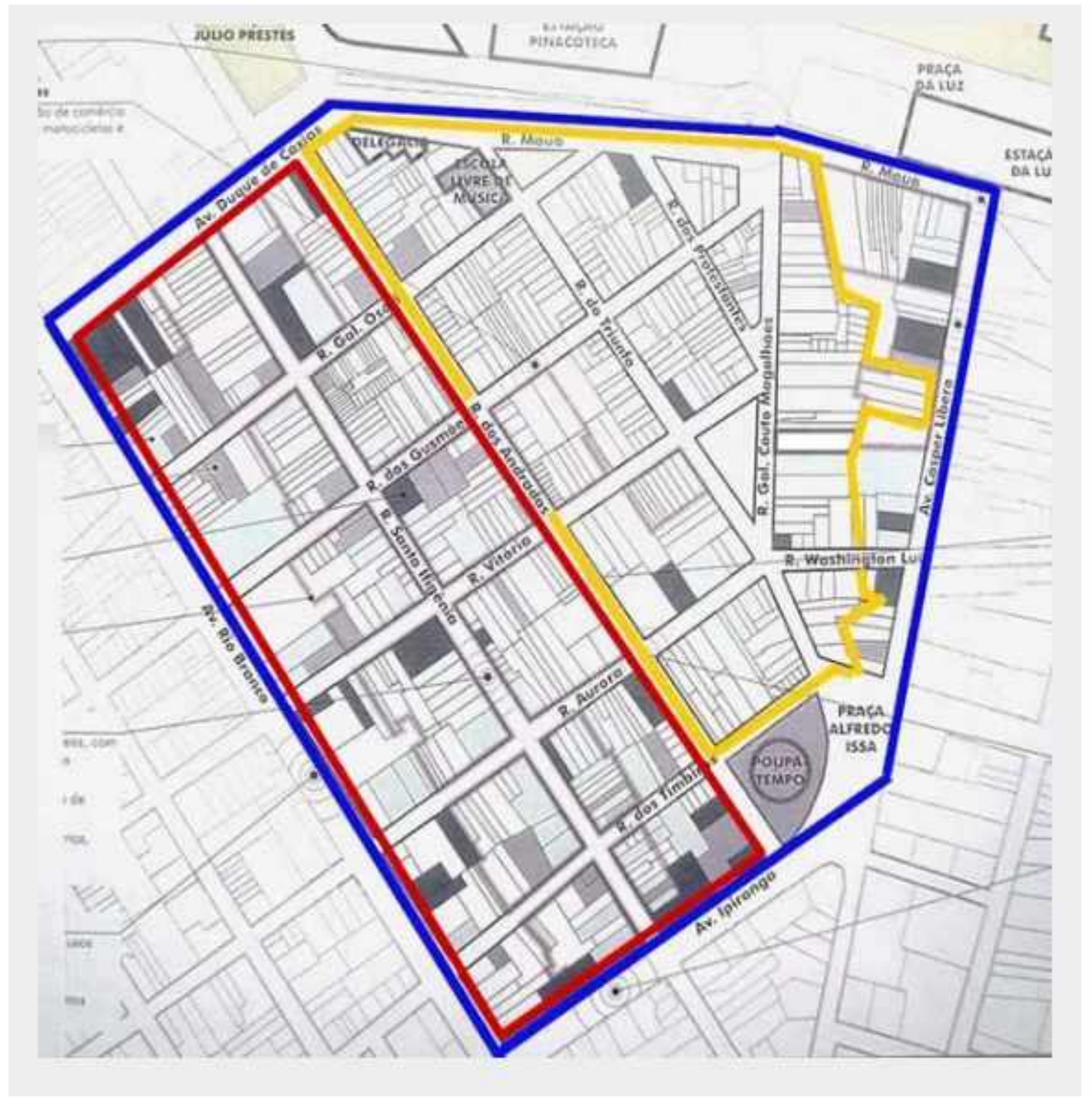

Mapa da área. Disponível em: http://oglobo.globo.com/fotos/2007/05/17mapa_sp_cracolândiapop.ppg. Acesso em: 15 SET 2018. 


\section{A VIZINHANÇA NA RODA}

O Teatro do Pessoal do Faroeste tornou-se um dos parceiros mais ativos na série de iniciativas que articulei na região da Luz, como veremos adiante. Mas antes, paralelo ao blog, A vizinhança se desdobrou em projeto para o Programa de Residência Artística da Casa das Caldeiras, ${ }^{17}$ além de estabelecer parceria com a Livraria da Vila durante o biênio 2014-2015. Nesse mesmo período, mais precisamente em novembro de 2014, fiz a formação em Terapia Comunitária Integrativa (TCI). O curso ministrado pelo psiquiatra e antropólogo Adalberto Barreto, em Beberibe, Ceará, visa desenvolver a capacidade de ouvir atentamente o outro e de falar de si.

A "roda comunitária" é um encontro de uma hora e meia, em que atua um mediador, e pode ser realizada em qualquer local, sem limites de participantes. A ideia é compartilhar experiências de vida e saberes de forma horizontal e circular. Cada participante torna-se terapeuta de si mesmo a partir da escuta das histórias de vida que ali são relatadas. Em um ambiente de acolhimento, todos experimentam ser corresponsáveis na busca de soluções e na superação dos desafios do cotidiano.

A metodologia desenvolvida por Adalberto Barreto tem a roda como marco ancestral. É resultado da prática da medicina social no Nordeste da seca, na lida com os indígenas, na assistência aos moradores da periferia de Fortaleza. Tem como foco promover reforço à ação comunitária, a cooperação e a criação de ambientes favoráveis à convivência no espaço público.

No ambiente de formação, no litoral do Ceará, as rodas foram marcadas fortemente pelas características da cultura nordestina, na qual a música, a dança, o repente e todas as manifestações populares expressam um tipo de troca, de expansividade no entrosamento.

\footnotetext{
${ }^{17} \mathrm{O}$ programa tem como objetivo dar condições para que artistas, grupos, coletividade e pesquisadores possam desenvolver seus projetos e seu processo de criação, relacionando-se com o patrimônio, o território e os demais residentes, experimentos e ações com o público frequentador, a interação das obras com a cidade e a relação afetiva com a memória coletiva. Ao final, todos são convidados a expor seus experimentos em uma mostra realizada na Casa das Caldeiras, chamada TEMPO FORTE.
} 
Em São Paulo, o desafio foi abrir mão da lista de compromissos para experimentar usufruir de um tempo livre, barreira que exige outro tipo de esforço na situação da megalópole. Como se estivéssemos empobrecidos da leveza do improviso e necessitássemos de uma certa delicadeza na redescoberta do quanto é surpreendente experimentar uma roda de conversa, experimentar o cuidar de si.

Da partilha de pequenas felicidades vividas à troca de abraços no início da roda, buscávamos (e continuamos buscando) o cultivo de sensibilidades, gostos, afetos, escolhas e afinidades éticas e estéticas que levem em consideração, sobretudo, o respeito à diversidade, à inclusão, ao desejo de participar, interagir e coexistir.

Figura 6 - Banner convida para uma das várias rodas comunitárias, na Livraria da Vila, em São Paulo, SP.

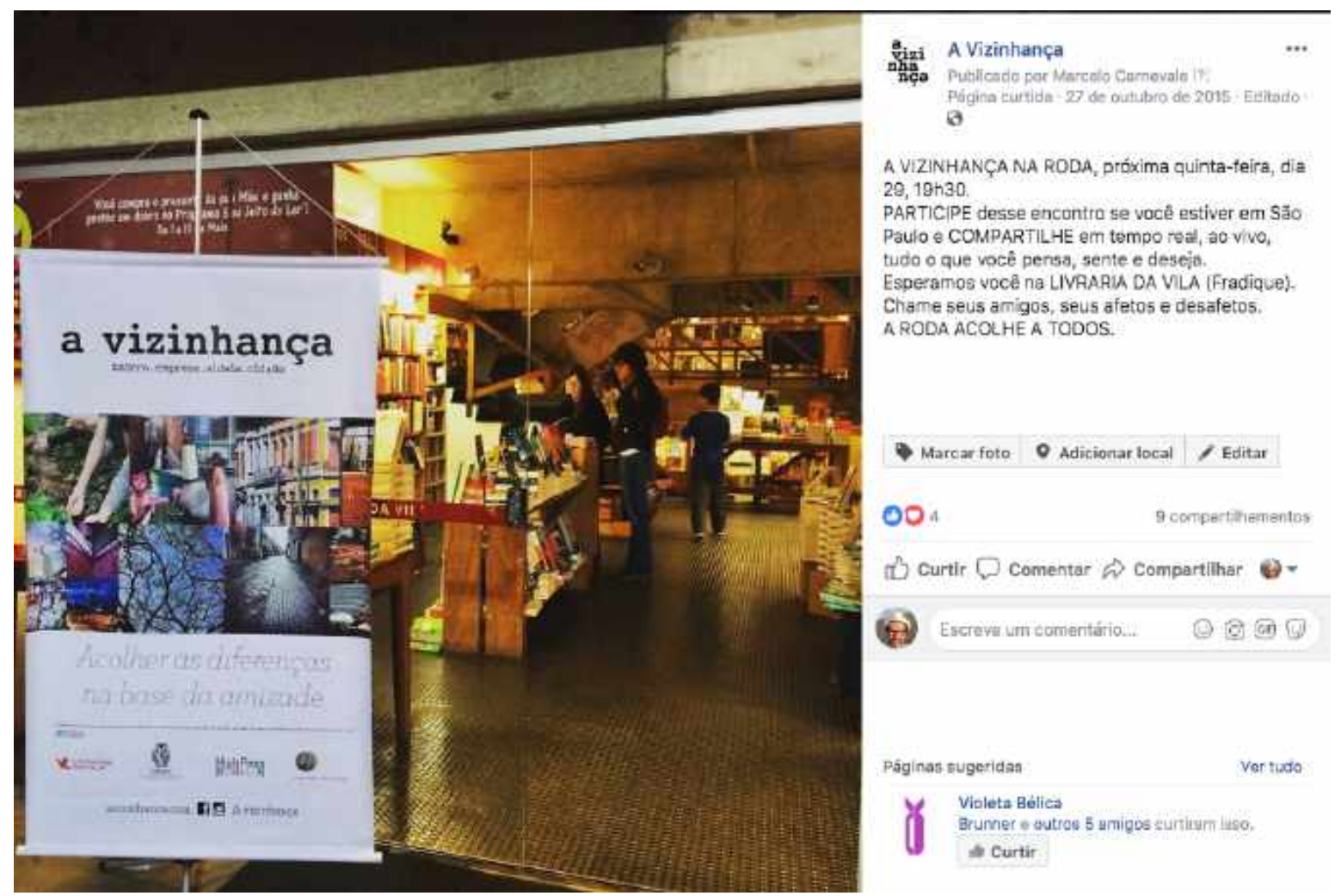

Fazer a roda girar em outras vizinhanças, para além da zona oeste, foi a perspectiva que alavancou a investida no centro da cidade de São Paulo. Vale recorrer a mais um registro do blog cuja publicação, no final de 2015, antevê a mudança de eixo das articulações de $A$ 
vizinhança na Roda para a região da Luz. O título do texto assume propositadamente o nome de Recomeço, em referência à unidade de atendimento que funciona na Rua Helvétia, no centro de São Paulo, e que leva o mesmo nome do programa para usuários de crack mantido pelo Governo Estadual. ${ }^{18}$

Foi o primeiro contato com a região mais problemática da Cracolândia, conhecida como fluxo, muito bem definida pelo antropólogo Ygor Alves:

O fluxo é uma aglomeração humana com dezenas ou mesmo centenas de usuários de crack a depender de diversos fatores, desde climáticos, passando pela repressão policial ao tráfico, até a proximidade ou não dos dias de pagamento. A disponibilidade da droga também é fator importante na construção e localização do fluxo. Ele está onde há droga e vice-versa; o crack é levado para próximo aos usuários e estes, por sua vez, se dirigem para o local com maior disponibilidade de crack. Aparentemente, próximo ao fluxo, ou melhor, dentro dele, os blocos - como são chamadas as pedras de crack para venda - são mais "bem fechados", termo utilizado para se referir às pedras maiores e com embalagens ainda não violadas. A região é repleta de biqueiras e hotéis com quartos disponíveis para curtos períodos e tolerantes com o uso, além de albergues privados com preços de sete a dez reais, sendo o leito em quarto compartilhado com direito a armário, banho e café da manhã. Do fluxo as pedras disponíveis podem ser frações do bloco original, sem necessariamente ter um preço menor. Dentro e fora dele, pode-se adquirir qualquer fração do bloco até chegar a doses unitárias, ou seja, suficiente para um trago, nome dado à unidade de consumo do crack. Estas frações da pedra original de crack são trocadas - também os mais diversos bens e serviços dentro do circuito da treta, tornando o fluxo um local de imensa agitação e até abrindo espaço a profissionais da treta, ou indivíduos dedicados a comprar e vender objetos usados e novos dispostos em cima de lonas alojadas sobre do asfalto. ${ }^{19}$

\footnotetext{
${ }^{18}$ A Unidade Recomeço iniciou suas atividades em julho de 2014 e é gerenciada pela Associação Paulista para o Desenvolvimento da Medicina (SPDM), uma organização social contratada pelo Programa Recomeço para gerenciar o equipamento. Fica na Rua Helvetia, 55, região central de São Paulo, e realiza cerca de 600 abordagens por mês, com aproximadamente 200 encaminhamentos para tratamento, no mesmo período. Disponível em: http://www.saopaulo.sp.gov.br/spnoticias/programa-recomeco-o-inicio-da-recuperacao-comeca-na-abordagem/. Acesso em: 22 dez. 2020.

19 Disponível em: https://www.academia.edu/12872751/A_Cracol\%C3\%A2ndia_como_Communitas_e_o_frade_craqueiro. Acesso em: 22 dez. 2020.
} 
O texto publicado no blog $A$ vizinhança expressava o impacto da surpresa, o choque de realidade absorvido com uma visita guiada pelo diretor técnico do Centro de Referência de Álcool, Tabaco e Outras Drogas (CRATOD), dr. Marcelo Ribeiro, ao endereço da recéminaugurada Unidade Recomeço, no epicentro do fluxo.

A estratégia de complementaridade dos dois endereços, ambos vinculados à Secretaria de Estado da Saúde, lidava com a transferência de know-how e alinhamento das abordagens propostas pelo Cratod na Rua Prates, para incremento do Programa Recomeço na Rua Helvetia. Além da triagem e do acolhimento, o Centro de Referência oferecia consultas clínicas e psiquiátricas, serviço odontológico, oficinas terapêuticas, entre outras. Esses atendimentos multidisciplinares transformaram-no na principal porta de entrada do Programa Recomeço na capital paulista.

O desenho operacional da dinâmica de abordagem contava com uma estratégia de convencimento do usuário sobre a necessidade de aceitar o tratamento da dependência química oferecido pela Unidade Recomeço. Aceito o convite, o usuário iniciava a primeira etapa na sede do Cratod para num segundo momento ser encaminhado para a rede de assistência do Centro de Atenção Psicossocial (CAPs) e, também para as comunidades terapêuticas vinculadas ao Programa Recomeço. Se a indicação era a internação médica, a própria Unidade contava com uma enfermaria para desintoxicação de pacientes, instalada em dois andares do prédio e com médicos, enfermeiros e psicólogos, com funcionamento 24 horas.

O encontro com o dr. Marcelo Ribeiro foi intermediado por outro psiquiatra, o dr. Álvaro Ancona, coordenador do Ambulatório de Transtorno Borderline do Programa de Atendimento e Pesquisa em Violência da Universidade Federal de São Paulo, PROVEUnifesp. ${ }^{20}$ Foi por essa via, da psiquiatria e da esfera do poder público estadual, que conheci o desafio de atender a uma população estimada em 1.800 frequentadores flutuantes da cena de uso do crack, com uma média de 8 mil pessoas cadastradas na Unidade Recomeço.

\footnotetext{
${ }^{20}$ PROVE é um programa ligado à Universidade Federal de São Paulo e ao Centro de Estudos Paulista de Psiquiatria. Atende crianças, jovens e adultos que desenvolveram o Transtorno de Estresse Pós-Traumático (TEPT) após um evento ou uma experiência de violência extrema.
} 
Nesse mesmo dia, cruzei a linha que tornava incompreensível a complexidade da situação que envolvia a presença dos usuários de crack num tipo de confinamento a céu aberto, pondo em xeque políticas públicas, autoridades, agentes de saúde, assistentes sociais e toda rede de redução de danos presente no fluxo.

Pude tomar ciência que, mesmo sendo representante de uma das instituições mais atuantes na região, Marcelo Ribeiro compartilhava a dificuldade de se articular em rede com as lideranças municipais e com outros agentes qualificados para a lida com os usuários. Saímos da sede do Cratod na rua Prates, no Bom Retiro, e seguimos até a Unidade Recomeço, num carro oficial que estacionou num descampado atrás do prédio. Ali, informados da nossa visita, negociaram com o tráfico a nossa incursão na área do fluxo.

O relato reproduzido na próxima página, publicado como texto do blog $A$ vizinhança, em 18 de dezembro de 2015, expressa como essa visita ao território marcou profundamente a minha relação com a região da Luz. 
Figura 7 - Foto publicada no post "O recomeço" em 18/12/2015.

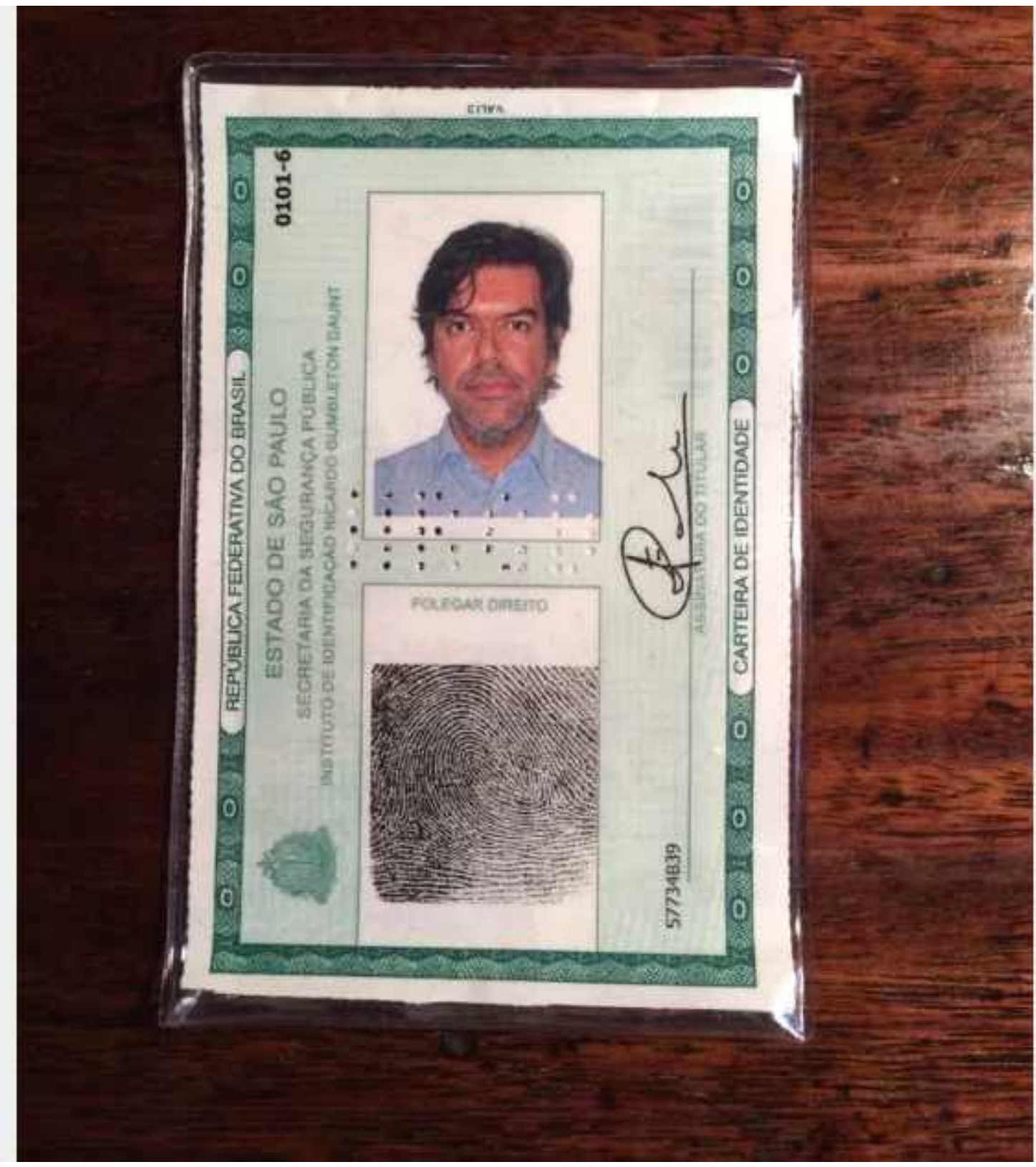




\section{O recomeço}

A foto do meu novo registro geral - que substituiu o documento antigo e emitido há muito tempo no Rio de Janeiro - é um flagrante da minha inquietação paulistana: o que constitui a nossa identidade? Qual o lugar do sujeito desenraizado? A qual vizinhança pertencemos?

Esse espanto garante um exercício constante de olhar os detalhes da cena urbana, elegendo o que nos é familiar e o que nos amedronta.

O medo paulistano da convivência com o que é estranho não mora em mim, não me paralisa. Ao contrário, me possibilita o movimento e algumas descobertas, mesmo que a cidade se agigante e que a gente desapareça nela.

Não se trata de um simples deslocamento pelo espaço, mas de uma postura que me permite andar por aí, entrar num beco, descobrir uma escada de acesso. A ideia é a mesma: encarar a topografia paulistana que sobe e desce na maré de concreto. Andar e conquistar cada topo em busca de alguma visão não consolidada sobre as coisas. O que pulsa?

Pergunta que lateja na minha cabeça e que, sem resposta fácil, me obriga a circular. Amar São Paulo exige outro tipo de disponibilidade para encontrar o amor.

\section{O fluxo e a Luz}

Nessa utopia, o desejo me colocou diante da região da Luz. Lá mora uma verdade sobre o que produzimos coletivamente: a miséria humana.

Atravessar o fluxo da Cracolândia é um caminho sem volta em sentidos muito distintos: da tomada de consciência do que somos capazes de produzir e ignorar como sociedade, da chaga que purga o inumano em nós como ferida aberta no coração histórico da cidade.

Minha identidade paulistana sofreu esse ajuste, que permitiu aos meus olhos vasculhar os detalhes do fluxo sob a teia de aranha do náilon suspenso a apenas um metro e meio de altura, coberto por plásticos capazes de abrigar o que jamais tinha visto antes: um viveiro de corpos magnetizados pelo crack.

Centenas de homens e mulheres numa convulsão do que não cabe, do que não tem mérito, do que não conduz e nem é conduzido e que é nosso, também, como cidadãos de São Paulo.

Bicheira ativa numa concentração de indigentes, com suas tramas, subtramas, violências subreptícias numa frequência de desfiguração e de desenraizamento d'alma. Monitorada por uma aliança do poder público, difusa na poeira de elementos químicos. Ardendo aos nossos olhos do meio-dia.

Ali, cabe a mais dura pergunta já feita por Primo Levi sobre o holocausto: "É isto um homem?" 
Sem respostas, sigo. Não estou sozinho nessa incursão pela região da Luz, existe muita gente disposta nessa vizinhança. A começar pelo meu amigo Paulo Farias, do Teatro do Pessoal do Faroeste e os inúmeros profissionais da saúde, numa rotina de trabalho inimaginável (Programa Recomeço e Projeto De Braços Abertos).

Gente empenhada a esperar pelo primeiro sinal que indique o desejo de mudança como meu xará, o dr. Marcelo Ribeiro, diretor do Cratod, que generosamente me guiou nesse cenário labiríntico e invisível para a maioria dos paulistanos.

O desejo de ruptura com o consumo do crack demanda um esforço muito brutal do usuário. Não menos que o nosso para rompermos com a inércia e detonarmos a hipocrisia que nos impede de contribuir de fato com o exercício da cidadania.

Estamos todos interligados sob a mesma teia que corta o céu de São Paulo. O risco que estica a corda na Rua Helvétia, na Luz, é o mesmo que tensiona a respiração da família na sala de estar da classe média. Somos os mesmos, mas a solidariedade é um aprendizado constante. O convite ao recomeço é amplo, geral e irrestrito.

Por coincidência, meu RG paulistano ficou pronto no Poupatempo da Luz, nesse mesmo dia da visita à Cracolândia. Saí do atendimento com a sensação de que a cidade me acolhe e me oferece as condições e o tempo para ficar e agir. Obrigado, São Paulo. Obrigado a vocês pelo apoio ao projeto $A$ vizinhança.

Feliz Natal!

A experiência foi decisiva para repensar o local de atuação e a agenda de $A$ vizinhança na roda, até então limitada a endereços estabelecidos na zona oeste da cidade - como a Casa das Caldeiras e a Livraria da Vila, no auditório da loja Fradique Coutinho. O desejo de mudar para a Luz nasceu da ambição de chegar em bairros nos quais imperasse a diversidade.

Como em toda aproximação, leva-se tempo para conhecer as instituições e seus jogos de interesses, bem como as disputas políticas e correntes ideológicas por detrás das agendas e projetos. A estratégia sempre foi a de não optar por nenhum tipo de adesão programática para poder transitar entre os diferentes atores, com o objetivo de escutar quem estivesse disposto ao diálogo.

A movimentação da Vila Madalena para a Luz apoiava-se na mesma vontade de escutar a cidade para colocar em prática os encontros de $A$ vizinhança na roda e experimentar a palavra como um território de coexistência. Segui a mesma adaptação livre da metodologia utilizada pela Terapia Comunitária Integrativa, como prática do acolhimento das rodas comunitárias. Apesar da orientação para contemplar a atuação de dois terapeutas, trabalhei sozinho na maioria das vezes. Vale conhecer o conjunto de regras básicas, detalhadas no roteiro que faz parte do material de formação do terapeuta comunitário. Idealizado pela equipe que auxilia Adalberto 
Barreto, serviu de guia para a condução das práticas, tanto na zona oeste como na zona central da cidade de São Paulo.

1 - ACOLHIMENTO ( + ou -7 minutos)

Dar as boas-vindas!

A Terapia Comunitária é um espaço de partilha das nossas inquietações do cotidiano. Para que isto aconteça precisamos seguir as regras:

- Não dar conselhos.

- Não julgar, não fazer sermão, não discutir, nem analisar.

- Falar de si - usando eu.

- Silêncio: respeitar a fala do outro.

- Propor música, piadas, provérbios que tenham a ver com o tema.

Exemplo de partilha: proponho partilhar alegrias, celebrações, aniversários, festas.

Dinâmica de aquecimento: passar a palavra para o terapeuta que vai conduzir a roda.

2 - ESCOLHA DO TEMA ( + ou -10 minutos)

Chegou a hora de escolher o tema de hoje.

Por que falar com a boca?

Quando a boca cala, os órgãos falam - o que não falamos com a boca dizemos com insônia, gastrite... Vamos falar pra não adoecer.

Do que falar? Daquilo que tira o sono - o que nos preocupa, como pai ou mãe de família na educação dos filhos, segurança, violência...

Não partilhe seus segredos - estamos num espaço público.

Quem gostaria de falar? Diga seu nome e em poucas palavras a sua inquietação.

Eu vou anotar e depois vamos selecionar apenas um tema.

Restituir após a fala de cada participante.

Deixe-me ver se entendi o seu sofrimento.

Exemplo: o sofrimento é a perda de um ente querido.

Após apresentar os temas sugeridos, dizer: qual desses temas eu proponho e por quê?

Fazer votação.

Dar uma palavra de conforto para os não votados.

3 - CONTEXTUALIZAÇÃO ( + ou -15 minutos)

A pessoa escolhida apresenta mais informações sobre sua inquietação.

Todos podem perguntar.

No final, o terapeuta agradece ao protagonista - faz elogio e pede para ele ficar em silêncio escutando a partilha do grupo.

4 - PROBLEMATIZAÇÃO - partilha de experiências (+ ou - 45 minutos)

Vamos falar agora de nós mesmos.

Mote coringa: quem já viveu algo parecido e como superou? 
Mote específico ou simbólico: quem já se sentiu enganado por alguém? E o que fez para superar?

5 - ENCERRAMENTO (+ ou -10 minutos)

Fazer a roda apoiados uns nos outros e pedir para balançar.

Quem quiser propor músicas, histórias, ditados, provérbios.

Conotação positiva para o protagonista.

Dirigir-se ao grupo: o que admirei nas falas e o que vou levando dessa roda?

\section{AS RODAS NA PERIFERIA DO CENTRO}

A proposta lidou com ajustes que correspondiam a uma condução mais centrada na palavra de acolhimento do que na dinâmica nordestina, a qual incluía cantoria, chistes, brincadeiras, no propósito de valorizar o "estar" na zona central da Luz. A adaptação foi necessária para escutar os habitantes da cidade e, portanto, escutar a própria cidade de São Paulo.

Privilegiei introduções mais intimistas, que buscassem conexões para fortalecer a relação dos participantes com as próprias origens. Ora indagando sobre o primeiro nome de parentes até a segunda linha de ascendência: avós, pais e suas respectivas cidades natais; ora relembrando que estar na Luz significava estar num lugar repleto de camadas históricas com a presença contínua de migrantes na busca por um uma vida melhor.

Numa roda, pudemos descobrir representantes de famílias indianas, japonesas, italianas, paulistanas e baianas. Nomes variados numa constelação de familiares ausentes/presentes a partir da evocação de seus representantes, ali, naquele instante. Situação que surpreendeu por romper os limites mais automáticos de sociabilidade, que invariavelmente estão mais voltados para breves apresentações e quase nunca para a história familiar. A tática surtiu um efeito interessante num pedaço da cidade pouco afeito a uma troca mais sensível. Minha intenção sempre foi a de abrir um campo afetivo improvável entre estranhos que, de repente, estavam falando de si através da própria família.

Nas rodas comunitárias realizadas na sede da Cia. Pessoal do Faroeste e na geodesia do pátio do Teatro de Contêiner da Cia Mungunzá, praticar a escuta a partir da eventual presença 
de usuários de crack, que circulavam pelo território e vez por outra aderiam à programação, gerou uma certeza: ninguém queria estar na Cracolândia, mas quem passava por lá estabelecia uma relação cheia de contradições que, nas suas nuances, sobrepunham desejo e repulsa. Essa contradição, noção de si, deriva e solidão, brotava da memória curta, sem elos, sem raízes, sem outra possibilidade que avançasse para além da revelação dos incômodos, angústias e dúvidas.

Nesses encontros, com registros que serão partilhados de forma mais detalhada em $A$ proximidade da roda, algo escapava do entendimento linear, do reconhecimento de um discurso elementar. O desafio lidava permanentemente com uma quebra de expectativas, que se abria para uma língua reinventada e repleta de sínteses como amargo-doce, sonho-acordado, mortodormindo.

Em As palavras e as coisas, Foucault pensa o momento do tempo em que a semelhança desfez sua dependência para com o saber e desapareceu, ao menos em parte do horizonte do conhecimento, "As coisas e as palavras vão separar-se". Trata-se do argumento do capítulo $A$ prosa do mundo, ${ }^{21}$ no qual o filósofo destaca um sistema ultrapassado que, no século XVI, se dedicava a conhecer o similar no qual a semelhança não poderia ser conhecida por si mesma já que os signos "não podiam ser outra coisa senão similitudes". Ao colocar o fim do conceito de representação como tema central do livro, Foucault nos possibilita compreender as ciências humanas como uma prática.

Não cabe, aqui, nessa investigação, o tentador mergulho nas quatro principais figuras que prescrevem suas articulações ao saber da semelhança: Convenientia, como "vizinhança dos lugares"; Aemulatio "uma semelhança sem contato"; Analogia, "as semelhanças mais sutis das relações"; Simpatia, que "atua em estado livre nas profundezas do mundo". Tampouco as rodas permitiam esse nível de complexidade numa escuta transitória que funcionava mais como um disparador de possibilidades.

Entretanto, vale resgatar na noção da convenientia algo que cintila como um dos valores das rodas do Centro. Trata-se de uma designação da força dos lugares com as coisas que se aproximam umas das outras por uma relação de vizinhança, porque se tocam nas bordas e “desse modo, comunica-se o movimento, comunicam-se as influências e as paixões, e também as propriedades". É no próprio século XVI que o saber arqueológico focaultiano vai localizar o

${ }^{21}$ FOUCAULT, Michel. As palavras e as coisas. 7. ed. São Paulo: Martins Fontes, 1995, p. 33. 
que na idade moderna irá compensar, e não confirmar, o funcionamento significativo da linguagem não mais como função significativa, mas como "aquele ser bruto esquecido" que, através da literatura, se faz em contradiscurso.

Dessa forma, a experiência da partilha na roda escapava da representação do mundo como amálgama das proximidades ou parecenças identitárias, pela via das relações abstratas de conveniência, no qual a semelhança, como afirma Foucault, "é menos uma relação exterior entre as coisas, mas o signo de um parentesco ao menos obscuro". Reforçada pela diversidade dos participantes, a palavra abria espaço para um certo tipo de afloramento como um iceberg imaginário $^{22}$ que se revelava pelas possibilidades de coexistência, "sem começo, sem termo e sem promessa".

Um tipo de ajuste mais próximo de um parentesco obscuro capaz de moldar-se na intensidade, do que nela vem de fora em ondas de afetos, tais quais: dor-alegre, raiva-brincante, amor-queixoso, pedido-desvalido. Esses agenciamentos tornaram a partilha possível, se entendermos que ela, a partilha, é que assegura o convite à vizinhança diminuta, a qual sempre dependeu do eco geral das rodas para se manifestar nas combinações de sentimentos e memórias expostos na fruição e intensidade do tempo livre.

Ainda pensando na prosa do mundo e no deslocamento para a região da Luz, inaugurouse uma prática mais desafiadora e inventiva, capaz de proporcionar a partir desses microeventos uma convergência no qual "o lugar e a similitude se imbricam" e promovem certos tipos de deslocamentos, paradoxo que tensiona as relações abstratas por esses parentescos obscuros e que, portanto, faz da semelhança (des)semelhança.

O obscurantismo possibilitou outra disposição para aproximações com pessoas e com outros seres, orgânicos e inorgânicos, soerguidos ou decaídos, mas presentes, como escreveu Elizabeth Bishop na sua impactante poesia: "os icebergs pedem à alma (ambos se autoproduzem com elementos pouco visíveis) vê-los assim: corpóreos, puros, eretos, indivisíveis".

\section{MÚLTIPLOS CONTORNOS}

\footnotetext{
${ }^{22}$ BISHOP, Elisabeth. Poemas. 1.ed. Tradução: Horácio Costa. São Paulo: Companhia das Letras, 1990, p. 23.
} 


\section{O DESEJO DE AVIZINHAR-SE}

Pensar vizinhança como leitmotiv de uma experiência que me permitiu colocar o corpo na região central de São Paulo, mais especificamente na Luz, deu-me a chance de reinventá-la como palavra e de ocupá-la inteiramente, como território de coexistência. Tomar a rua e lidar com os medos que remetiam aos conselhos maternos dos perigos que se mostram como desafios nas calçadas, nas encruzilhadas, na experiência de fora que na força mítica ganhava a projeção do mal, marginal, impuro, demoníaco, perverso, lascivo, luxuriento. Exu.

No sincretismo religioso carioca, o perigo tinha cor: preto e vermelho, fumava cigarro, bebia cachaça e usava o sexo como ponta de lança ou renda misteriosa. Tentação dos corpos com espasmos das gargalhadas altas e pequenos gatilhos de sedução ou possessão sem volta, capazes de amarrar qualquer amor. Muitos anúncios colocados em postes de energia das calçadas ainda prometiam, e prometem, o retorno do enfeitiçado em três dias. Bastava visitar a cigana com alguns agrados. Mas independentemente dos oráculos, meu destino estava traçado: no calor da sensualidade do subúrbio carioca, aprendíamos a beijar literalmente agarrando o poste de energia. Fazíamos uma pequena fila e mesmo à porta de casa, onde residia a inocência da infância, experimentávamos o chamado da rua.

São Paulo proporcionou-me a continuidade dessa experiência muito tempo depois, num contexto que partilho nessa escrita. Por mais que no Centro Velho, a Boca do Lixo estivesse aparentemente morta, sem a produção fervilhante de filmes que a projetou no cinema nacional, o vazio estava cheio do que Bataille compreende como a força incondicionada do heterogêneo. Evoco a figura do acéfalo apresentada na introdução de $O$ erotismo, pelo tradutor da obra, Fernando Sheibe, como essa força na qual "a negação da cabeça é a negação da razão e do telos, do líder, de Deus, do capital e, em última instância, do eu", ${ }^{23}$ como a força que permeou minha jornada pelas ruas paulistanas ao defrontar-me, cara a cara, com as intensidades possuídas da despossessão.

Essa aproximação do meu corpo com os dos seres que ignoram a proibição, fez da minha jornada, como ativista e pesquisador, uma abertura para, como diz Canclini, citando Ítalo

${ }^{23}$ BATAILLE, George. O erotismo. $1^{\text {a }}$ ed. Belo Horizonte: Autêntica, 2017, p. 12. 
Calvino: "expressar com a maior precisão possível o aspecto sensível das coisas". Nessa decadência da democracia Canclini, observa: "é chave a palavra (que) une o rastro visível com o invisível, com a coisa ausente, com a coisa desejada e temida, como frágil ponte improvisada estendida sobre o vazio". ${ }^{24}$

O que coube a partir da prática e do que me permitiu revisitar o que se evidencia na experiência foi fazer da vizinhança um convite permanente à coexistência. Apostar na sincronia da empiria com a reflexão teórica que expressa um saber estranhado, para ficar ainda com Canclini. Sem um distanciamento que permitiria um exercício de retórica ou ainda um enaltecimento do éthos. Mais próximo do desnudamento, proposto por Bataille, como estado de comunicação, como continuidade do ser para além do fechamento em si mesmo. O que coube foi um gesto obsceno, compreendendo a obscenidade "como a perturbação que desordena um estado dos corpos conforme à posse de si, à posse da individualidade duradoura e afirmada". ${ }^{25}$ A possessão da rua.

Escolhi enfatizar na palavra vizinhança a força do que ela expressa como arranjo coletivo e/ou partilha que nada tem a incluir a não ser a própria partilha, como pensa Nancy, em um alinhamento por coincidências de abordagem e/ou por diferenças não excludentes. Independente da fração de tempo que determina a possibilidade do avizinhar-se, o que entra em jogo pode ser comparado à destruição da estrutura do ser fechado, recriando a imagem de Bataille para pensar a despossessão como ação erótica, "o vaivém de ondas que penetram e se perdem umas nas outras". ${ }^{26}$ Penso numa sequência dessas ondas na praia que toma de assalto um grupo aleatório de banhistas e que ativa um estado de alerta geral. Surpreendidos pela série, como diriam os surfistas, nunca saberão de antemão como encarar o desafio do volume d'água e da correnteza no quebra-mar e, nesse caso ainda, quem vai escolher mergulhar no fundo e furar o paredão ou quem vai subir ao topo apostando na capacidade de vencer a elevação.

Vida e morte se diluem na mesma possibilidade de romper ou continuar o que cabe a cada um. Como se o interior não tivesse mais nada de interior e estivesse colocado nesse

\footnotetext{
${ }^{24}$ GARCIA CANCLINI, Néstor. O mundo inteiro como Lugar Estranho. São Paulo: Edusp, 2016, p. 142.

${ }^{25}$ BATAILLE, op. cit. p. 41. Há, ao contrário, despossessão no jogo dos órgãos que se derramam na renovação da fusão, semelhante ao vaivém das ondas que penetram e se perdem umas nas outras. Essa despossessão é tão completa que, no estado de nudez que se anuncia, que é seu emblema, a maior parte dos seres humanos se esconde, com mais forte razão se a ação erótica, que acaba de a desapossar, segue a nudez.

${ }^{26}$ Idem, p. 41.
} 
exterior incomensurável que, como observa Nancy, em Bataille, é a experiência moderna da comunidade: "nem obra a ser produzida, nem comunhão perdida, mas o espaço mesmo, o espaçamento da experiência de fora, do fora de si". ${ }^{27}$

Quais códigos possuímos como recurso e que se comunicam numa fração de tempo e nessa exposição de uns aos outros?

Para além da reflexão sobre os conjuntos de sentidos como marcas conceituais do avizinhar-se: (des)semelhança, proximidade e amizade, o que sustenta o arco teórico desse trabalho interdisciplinar é o exercício de pensar a vizinhança como um desdobramento de encontros propensos a coabitar conceitos sem receios, sem medo do outro humano e não humano e do que tudo isso traduz como fusão, como despossessão e desordenamento da vida.

Vizinhança como heterologia em Bataille, vizinhança como as palavras geradoras, em Paulo Freire; como o ser qualquer, em Agamben; como platôs, em Deleuze e Guattari; como heterotopia, por Foucault; como Terrápolis em SF, na escrita de Donna Haraway, compreendendo SF como palavra múltipla (science fiction, speculative fabulations, string figures, speculative feminism, science fact, so far) e jogos de response-ability; ${ }^{28}$ como Communitas, em Turner; como circuito dos afetos, em Saflate; como multiplicidade, em Viveiros de Castro; como comparição, em Jean-Luc Nancy; como refutação ao tempo, em Borges. Vizinhança como (re)vizinhar proposta que é defendida como minha hipótese, na parte 3.

Escapar das verdades preestabelecidas como alguém que abre mão da proteção de uma marquise em pleno temporal - mas sempre com alegria. Experimentar a vacância na cortina de átomos que se desloca num clinâmen, num desvio imperceptível a olhos nus mas percebido por Jorge Luis Borges no fragmento 91 de Heráclito, "Nunca entrarás duas vezes no mesmo rio" - admiro sua destreza dialética, pois a facilidade com que aceitamos o primeiro sentido ("O rio é outro") impõe-nos cladestinamente o outro ("Eu sou outro"). ${ }^{29}$. Ou ainda, como alguém que oferece um sorriso cúmplice para outro alguém no quebra-mar, que também sobreviveu à

\footnotetext{
${ }^{27}$ NANCY, Jean-Luc. A comunidade inoperada. Rio de Janeiro: 7Letras, 2016, p. 48.

28 Tradução livre do termo SF (ficção científica, fabulações especulativas, figuras tentaculares, feminismo especulativo, fato científico, até agora) e jogos de capacidade de resposta.

${ }^{29}$ BORGES, Jorge Luis. Obras completas de Jorge Luís Borges, vol 2. São Paulo: Globo, 1999, p. 157.
} 
sequência de ondas e que nessa troca de olhares também está a recuperar o fôlego na contingência das correntes marítimas.

O entusiasmo é fundamental para acreditarmos em certas possibilidades de vizinhança: a de encontrar um abrigo para proteger-se da chuva; a de que podemos criar um elo instantâneo com outras pessoas pelo intento de furar ondas e coabitar o inconstante que faz a vida flutuar no aqui e agora. Com a refutação do tempo proposta por Borges, a partir da rejeição da índole sucessiva da linguagem e apostando num certo tipo de coexistência que nega a sucessão dos termos de uma série, o que desejamos é a consciência liberada para o que importa: as relações.

Pensar com alegria sempre foi o convite do meu eterno mestre Claudio Ulpiano. Lá atrás, no início de tudo, ele soprou a riqueza do seu pensamento como música nos meus ouvidos, na minha memória afetiva dos 20 anos: "heterônimos, blocos de sensações, singularidades nômades e selvagens; ou melhor, o dionisíaco, a vontade de potência, ligados ao préindividual". Nessas lembranças, nas quais a música da voz do mestre conduz à grande aventura do pensamento em Deleuze, ${ }^{30}$ algumas palavras e expressões revelaram a beleza da primeira escuta: "Há no mundo alguma coisa que força a pensar. Esse algo é o objeto de um encontro fundamental e não de uma recognição". 31

Minha escrita e a escuta de outras vozes registram o que está impresso na memória do corpo e do espírito, numa trama textual que evoca o estar presente, atento, próximo, misturado às vizinhanças por onde pude me conectar como um qualquer. Sem dúvida, um encontro com a cidade. Empenhado a buscar outros olhos, outras janelas da alma, ${ }^{32}$ num exercício permanente do primeiro plano, do enquadramento que silenciosamente produzisse uma aproximação com as situações e as pessoas, sem exigir nenhum tipo de reconhecimento pela minha presença, mas sem negar meu olhar, minha voz e meus ouvidos.

\footnotetext{
${ }^{30}$ ULPIANO, Claudio. Gilles Deleuze: a grande aventura do pensamento, $1^{\mathrm{a}}$ ed. Rio de Janeiro: Funemac Livros, 2013.

${ }^{31}$ Id., ibid., p. 29. Parte da resposta de Claudio Ulpiano às questões: Quem fala em filosofia? Quem é o sujeito do discurso filosófico? E, por consequência, quem é aquele que cria novos afetos e novos perceptos na obra de arte, ou quem são Schumman, Cage, Bacon, Robert Bresson, Virgínia Woolf: egos individuais, eus pessoais, ou o caos sem fundo, informe e terrível? De fato, sob o regime de um novo valor de verdade, do qual participa a experiência do vago e do indecidível, do múltiplo e do falso - este, no regime dos incompossíveis (...).

32 Referência ao filme de João Jardim e Walter Carvalho, no qual dezenove pessoas com diferentes graus de deficiência visual, da miopia discreta à cegueira total, falam como se veem, como veem os outros e como percebem o mundo.
} 
Fotos, cadernos, diário, cafés, cervejas, ruas desertas, teatros lotados, salas de aula, transporte público, praças, passeatas, oficinas, viagens, Internet, saraus, performances, rodas de conversa, vinhos, reuniões do conselho universitário, mudança residencial para o Centro Velho, muitos abraços, tudo isso compôs essa escrita, a partir do que Michel Maffesoli apresenta como a via crucis do ato de conhecimento, "um saber erótico que ama o mundo que descreve". 33

Uma errância que me fez experimentar várias São Paulo, também como espaço interdisciplinar, à medida que transitar pelos lugares proporcionou-me a ampliação da experiência de troca com profissionais da saúde, da assistência social, do urbanismo, da segurança pública, da psicologia social, do teatro, das artes plásticas e da educação.

Sem um mapa de campo balizado por critérios limitantes a priori, o que foi cartografado surgiu de um limbo no qual todos os tipos de vestígios do centro da cidade eram cartões postais, novas pistas e novos saberes. A cidade como um livro nas mãos, tal qual pensou Walter Benjamin, em Rua de Mão Única. Diário que mesmo repleto de acontecimentos permitiu-me generosamente reaprender um tipo de escrita que acolheu silêncios, soluços e outros sons.

A experiência ativista na pesquisa acadêmica se deu num registro convergente com o pensamento de Maffesoli e o rigor a partir da conivência e da empatia:

Mais do que uma razão a priori, convém pôr em ação uma compreensão a posteriori, que se apoie sobre uma descrição rigorosa feita de conivência e de empatia (Einfühlung). Esta última, em particular, é de capital importância, nos faz entrar no próprio coração de nosso objeto de estudo, vibrar com suas emoções, participar de seus afetos, compreender o complexo arabesco dos sentimentos e das interações de que ele está impregnado. Por isso mesmo, o observador social não tem pretensões à objetividade absoluta, não tem uma posição impositiva, não é o simples adjuvante de um poder qualquer que seja; ele é, simplesmente, parte integrante do objeto estudado, desenvolve um saber puro, um conhecimento erótico. ${ }^{34}$

Quando surgiu o desejo de assumir a própria voz nessa escrita sobre vizinhança, quando adentrei pela vereda e abri espaço para uma exposição total da minha jornada, ficou evidente a opção que me situou na narrativa. Não fazia sentido revalidar uma estratégia baseada na

\footnotetext{
${ }^{33}$ MAFFESOLI, Michel. Elogio da razão sensivel. Petrópolis: Vozes, 2005, p. 14.

${ }^{34}$ Id., ibid., p. 47.
} 
reflexão de Foucault sobre $O$ que é um autor?, "representar o papel de morto no jogo da escrita". ${ }^{35}$ Pensamento que amalgamou meu fazer literário até então.

Ao contrário, se pude experimentar o desafio dessa escolha é porque essa escrita tem o rigor de quem está implicado em escrever sobre o que viveu, e vive, como conhecimento erótico.

\section{O LUGAR NENHUM, O LUGAR DE TODES}

Vizinhança pelas descobertas resultantes dos encontros voláteis para escapar do que Agamben define como a hipócrita ficção da insubstituibilidade do indivíduo. Investigar desdobramentos de aproximação como um certo tipo de força na qual não cabe posições fixas, mas a fricção entre o visível e o invisível e o que nos captura para além da representação.

Um tipo de cumplicidade pelo que não é dado, presente na análise preciosa de Foucault para Las Meninas ${ }^{36}$ de Velasquez, onde o filósofo destaca o que se manifesta no jogo da invisibilidade profunda do que se vê para além do representado. Não seria essa a condição do que nos é reservado como habitantes dos grandes centros urbanos? Desafiados a todo instante pela movimentação num território que, também, se movimenta? Uma negociação constante para perscrutar algo que não cabe num certo tipo de enquadramento limitante e que, diferentemente do primeiro plano cinematográfico, não aproxima para acentuar linhas de fuga.

Vizinhança que se dá nesse entre onde só existem lugares vicários como na comunidade católica em terra islâmica, citada por Agamben, batizada de Badaliya, termo árabe que indica substituição.

(...) substituir alguém não significa compensar o que lhe falta nem corrigir os seus erros, mas expatriar-se nele tal qual é para oferecer hospitalidade a Cristo na sua própria alma, no seu próprio ter-lugar. Essa substituição não conhece mais lugar próprio, mas para ela, o ter-lugar de todo ser singular já sempre comum, espaço vazio oferecido à única e irrevogável hospitalidade.

\footnotetext{
${ }^{35}$ FOUCAULT, Michel. O que é um autor?. Lisboa: Passagens/Vega, s/d.

${ }^{36}$ FOUCAULT, Michel. As palavras e as coisas. São Paulo: Martins Fontes, 1995, p. 31.
} 
A destruição do muro que divide o Éden do Gehinnom é, portanto, a intenção secreta que anima Badaliya. Porque nessa comunidade só há lugares vicários, e Éden e Gehinnom são apenas o nome desta vez comum. À hipócrita ficção da insubstituibilidade do indivíduo singular, que na nossa cultura serve apenas para garantir a sua universa representatibilidade, a Badaliya opõe uma substituibilidade incondicionada, sem representante nem representação possível, uma comunidade absolutamente irrepresentável.

Desse modo, o múltiplo lugar comum, que no Talmude se apresenta como o lugar do vizinho que cada homem inevitavelmente recebe, não é senão o advir a si mesma de toda singularidade, o seu ser qualquer - isto é, tal qual. ${ }^{37}$

Abrir esse espaço é fundamental, por que o desejo de avizinhar-se é primeiramente subjetivo e íntimo. Um exercício de hospitalidade que se dá à medida que acumulamos vivências citadinas e ausências de respostas para tantas surpresas no que se apresenta. Essas ausências, essas incompreensões são importantes para que o estranhamento permita perceber o que escapa aos nossos olhos no jogo foucaultiano da visibilidade/invisibilidade, que os deslocamentos nos proporcionam como capazes de colocar em questão a potência do onde, tal qual indaga Anne Dufourmantelle:

A questão "onde?" não tem idade: transitiva, ela dá como essencial a relação com o lugar, com a morada, com o sem-lugar, e recusa por sua própria função o pensamento em sua relação de compreensão do objeto. A verdade está no movimento que a descobre e no rastro que a nomeia. Trata-se menos de definir, de explicar, de compreender, que de medir-se com o objeto pensado descobrindo nesse enfrentamento o território no qual a questão se inscreve; sua justeza. É por isso que "a fronteira, o limite, o limiar, o passo adiante nesse limiar" frequentemente retornam à linguagem de Derrida, como se a impossibilidade de delimitar um território estável em que o pensamento pudesse estabelecer-se fosse provocadora do próprio pensamento. "Para oferecer hospitalidade', pergunta-se ele, "é preciso partir da existência segura de uma morada ou apenas a partir do deslocamento do sem-abrigo, do semteto, que pode se abrir para a autenticidade da hospitalidade? Talvez apenas aquele que suporta a experiência da privação da casa pode oferecer a hospitalidade. $^{38}$

37 AGAMBEN, Giorgio. A comunidade que vem. Belo Horizonte: Autêntica, 2013, p. 31.

${ }^{38}$ DERRIDA, Jacques. Da hospitalidade. São Paulo: Escuta, 2003, p. 52-54. 
Liberar-se das certezas para aceitar que a dinâmica do acolhimento é a de não conhecer mais lugar próprio. Encontrar no comum a coexistência é lidar com descobertas aparentemente óbvias, mas paradoxalmente surpreendentes, num corpo social marcado por uma integridade como sinônimo dos predicados que possuímos, como observa Vladimir Safatle. A obviedade mora no resgate do prazer em viver coletivamente e na descoberta que ao partilharmos medos, felicidades e sonhos, conseguimos revigorar o que Safatle nomeou de circuito dos afetos, numa reflexão sobre a articulação entre afetos e corpo político.

É possível despir-se dos predicados, substituir alguém num expatriar-se dele para oferecer hospitalidade incondicionada, é possível perceber uma convergência entre os pensamentos de Derrida, Agamben e a proposta de Safatle quando se pensa o desabar em moto continuo:

(...) uma indiferença com sua capacidade antipredicativa, com sua despossessão generalizada de si. "Indiferença" não significa desafecção, mas constituição de uma "zona objetiva de indiscernibilidade" e de indistinção, na qual determinações por propriedade desabem em moto continuo". 39

Entre o visível e o invisível, o que prevalece é a desconfiguração da identidade determinante e o descondicionamento de predicados, como possibilidade de experimentar a diversidade. Algo que coloca o inclassificável como a qualidade do estar junto. Pois nessa hospitalidade não é mais possível restaurar a distinção, nem que as condições de permanência se limitem às regras da nossa casa. Ceder lugar ao, como nomeia Derrida, "outro absoluto, desconhecido, anônimo" sem exigir dele reciprocidade.

Se pensarmos no erotismo guiado pelo desejo de viver a cidade, na qual se faz necessário experimentar a violência dessa liberação do ser, podemos pensar no deslocamento para um estado de comunicação que entende o avizinhar-se como um movimento, num jogo que experimenta o espanto do espaço público e tudo o que nele existe: lixo, barulho, carros, gente, sol, música, breu.

${ }^{39}$ SAFATLE, Vladimir. O circuito dos afetos. São Paulo: Cosac Naify, 2015, p. 31. 
Um avizinhar-se que revela a busca de viver para além do fechamento em si mesmo, abrindo-se à continuidade através do que a rua oferece e da escuta atenta que revela seus segredos, na obscenidade perturbadora da cidade. Algo próximo de uma traição daquilo que nos inspira certezas, algo como a alma imoral ${ }^{40}$ ou ainda como um exercício de elegância, lembrando a poesia de Paulo Leminski na música de Itamar Assumpção: "um homem com uma dor é muito mais elegante, caminha assim de lado como se chegando atrasado andasse mais adiante".

Mexer na rotina dos espaços, criar novos ritmos com o corpo e criar ações espontâneas para algo aparentemente inadequado na condição urbana da cidade de São Paulo: estar e usufruir da rua. Tipo de hospitalidade que promove outras aproximações com a multiplicidade.

Viveiros de Castro reflete, na segunda parte de Metafisicas canibais, em "Capitalismo e esquizofrenia de um ponto de vista antropológico", sobre transformar o conceito de multiplicidade na intenção filosófico-política de cortar o vínculo natural entre o conceito e o poder, entre filosofia e Estado.

À medida que temos no perspectivismo o ponto de fuga das verdades absolutas, liberamo-nos para viver inúmeras situações que nos aproximam ou nos repelem do vivido, às vezes ao mesmo tempo. Desenhos de vizinhança que irão se multiplicar pela "diferença intensiva pura, "essa irredutível desigualdade que forma a condição do mundo"”.41

Essa abertura é promovida pela multiplicidade que aflora da ruptura com a assimilação das narrativas hegemônicas e que nos coloca diante de um tipo de aproximação forte, liberada de propriedades constitutivas ou critérios de inclusão classificatória, como observa Viveiros de Castro:

\footnotetext{
Se é verdade que "não há entidade sem identidade", como Quine famosamente aliterou, então deve-se concluir que as multiplicidades não podem pretender a tal estatuto. Um rizoma não se comporta como uma entidade, nem instancia um tipo; ele é um sistema reticular acentrado formado por relações intensivas ("devires") entre singularidades heterogêneas que correspondem a individuações extrassubstantivas, ou eventos (as "heceidades"). Assim, uma multiplicidade rizomática não é realmente um ser, um "ente", mas um

40 Título do livro de Nilton Bonder, A alma imoral, o qual questiona o "padrão humano automático de torpor" como produtor de uma subserviência à moral da nossa cultura.

${ }^{41}$ VIVEIROS DE CASTRO, Eduardo. Metafisicas canibais. São Paulo: Cosac Naify/ n-1 edições, 2015, p. 116.
} 
agenciamento de devires, um "entre": um diference engine, ou antes, o diagrama intensivo de seu funcionamento. ${ }^{42}$

Pensar a vizinhança como um sistema reticular acentrado, sem um estatuto identitário, é pensar um sistema de relações intensivas que, lembrando Borges, rejeita a índole sucessiva da linguagem para articular-se por devires entre singularidades, como ondulações presentes no conceito de communitas em que Victor Turner aponta para uma situação na qual aspectos relacionais entre indivíduos concretos, históricos, idiossincráticos, afloram de maneira espontânea e imediata, sem mediações.

(...) estes indivíduos não estão segmentados em função e posições sociais, porém defrontam-se uns com os outros mais propriamente à maneira do " $\mathrm{Eu}$ e Tu", de Martin Buber. Juntamente com este confronto direto, imediato e total de identidades humanas, existe a tendência a ocorrer um modelo de sociedade como uma "communitas" homogênea e não estruturada, cujas fronteiras coincidem idealmente com as da espécie humana. A "communitas", sob este aspecto, é acentuadamente diferente da "solidariedade" de Durkeheim, cuja força depende do contraste entre "interior ao grupo" e "exterior ao grupo". Até certo ponto, a "communitas" está para a solidariedade como a "moral aberta" de Henri Bergson está para sua "moral fechada". No entanto, a espontaneidade e a imediatidade da "communitas", opondo-se ao caráter jurídico e político da estrutura, podem raramente ser mantidas por muito tempo. ${ }^{43}$

Dessa maneira pude adotar uma cartografia rizomática, que longe de promover uma fuga para um bunker conceitual abstrato, serviu como condição para o mapeamento aplicado à pesquisa de campo no limite desse corpo a corpo. Prática que invariavelmente me fez deparar com algo parecido ao título do quadro de Regina Parra, Um Perigo, Uma Chance, ${ }^{44}$ o qual exibe uma floresta densa e quase noturna.

\footnotetext{
${ }^{42}$ Id., ibid. p. 117.

${ }^{43}$ TURNER, Victor W. O processo ritual: estrutura e anti-estrutura. Petrópolis: Vozes, 1974.p. 161

${ }^{44}$ A tela de Regina Parra foi exibida na galeria Millan, SP, em 2016. Segundo o curador Moacir dos Anjos "desde o título interrogativo da mostra - Por Que Tremes, Mulher? - há uma deliberada aposta na imprecisão do que é comunicado, como se apenas através da opacidade da linguagem empregada fosse possível falar claro. É somente quando se passa de um a outro deles que uma teia de sentidos vai sendo tramada em ricochete entre pinturas, desenhos, vídeo, texto e áudio". Disponível em: http://www.reginaparra.com.br/um-perigo-e-uma-chance. Acesso em: 22 dez. 2020.
} 
Se avizinhar a partir da associação em rede é sempre um perigo e uma chance, entendendo rede como um modo de inscrição ou de descrição capaz de se espraiar sem modelos, mais próximo de um estilhaçamento urbano no qual a reconfiguração se dá num jogo do acaso que tem a cidade como território-labirinto. O rizoma se destaca pela acentralidade, lida com a instabilidade e a criatividade do que é relacional, e assume a condição de um perspectivismo na multiplicidade. Viveiros de Castro lembra que "a multiplicidade não é algo maior que um, algo como uma pluralidade ou uma unidade superior; ela é, antes, algo menos que um, surgindo por subtração. ${ }^{45}$

E pela via da subtração, a língua se reinventa através do desejo das composições que podem ou não pretender a produção de narrativas, mas, eventualmente, apenas por se relacionarem desobrigadas da reprodução dos termos totalizantes, faz brotar a comunicação relacional afetiva. O verbo deixa de implicar a primeira pessoa do singular, que submete (algo) ao processo do raciocínio lógico e, portanto, exerce a capacidade de julgamento para fazer da ação o ato de acolhimento do incontido: a terceira pessoa, o outro.

Borges, indo além do idealismo de Hume, que, segundo o escritor argentino, pretendia um mundo de impressões evanescentes, sem matéria nem espírito, nem objetivo ou subjetivo, propõe uma mudança no preceito cartesiano "penso, logo existo", invalidando a postulação do eu que é "uma petição de princípio", para resgatar a proposta do físico alemão Lichtenberg e "em lugar de "penso" disséssemos impessoalmente "pensa", como quem diz "troveja" ou "relampeja". ${ }^{46}$

Essa outridade, esse afloramento da contração dos diferentes, que juntos compõem um patchwork sempre incompleto e menor que um todo, reflete desenhos de vizinhanças possíveis. Novas formas do avizinhar-se nas cidades, pela fragmentação dos encontros "eu e tu", no improviso dos arranjos coletivos, descontínuos, virtuais e reais como lugar, que Milton Santos considera novas formas de ações redefinindo a espacialidade por feixos de relações, "junto aos novos objetos, criados para atender às novas funções, velhos objetos permanecem e mudam de função". ${ }^{47}$ A coexistência não traz a possibilidade da definição de lugares, mas a multiplicidade

\footnotetext{
${ }^{45}$ VIVEIROS DE CASTRO, Eduardo. Metafísicas canibais. São Paulo: Cosac Naify e n-1 edições, 2015 , p. 117.

${ }^{46}$ BORGES, Jorge Luis. Obras completas de Jorge Luís Borges, vol 2. São Paulo: Globo, 1999, p. 154.

${ }^{47}$ SANTOS, Milton. A natureza do espaço: técnica e tempo, razão e emoção. São Paulo: Edusp, 2006, p. 62.
} 
de arranjos caóticos e, por essa via, suscita mecanismos de controle como reação dos que enxergam ameaça no protagonismo da diversidade.

\section{ACUPUNTURA URBANA NAS CIDADES GLOBAIS}

Em oposição às estruturas vertebradas do estado-nação, encontramos estruturas moleculares, como Appadurai coloca em $O$ medo do pequeno número ${ }^{48}$ e que, em tempos globais e digitais, se articulam e desarticulam na velocidade dos fluxos mais velozes. Mas nem sempre a palavra rede ganha uma nova lógica de celularidade, na qual prevalecem sistemas autônomos acentrados para comporem outros padrões.

A economia que promoveu a mudança das empresas multinacionais para as transnacionais e, agora, globais, alterou a geografia do capital e tornou difícil estimar a relevância desses sistemas autônomos. Appadurai observa que a aplacabilidade de certos protocolos legais, que garantem a difusão do que determina serem as boas práticas, dão os contornos ao conjunto de regras que orientam, dos recursos humanos às taxações e cobranças. Ele verifica como o sistema do estado-nação vertebrado é suportado pelo capitalismo vertebrado.

Num mundo guiado pela lógica do mercado, as conexões promovem operações impensáveis, como nesse exemplo que acompanhei: a tomada de decisão da contratação de um prestador de serviços, a PnB, num home office no bairro da Tijuca, zona norte do Rio de Janeiro, por um escritório em São Paulo, cujos detalhes contratuais são negociados pelo departamento jurídico no hub para a América Latina, em Miami.

A economia que promete parceiros interconectados em prol da participação em mercados maduros se vale da aliança que não promove autonomia e crescimento articulado com demandas locais. A inteireza do negócio obedece à regra do contratante, que impõe um modelo desenhado, segundo Appadurai, "pelos tríplices motores do capital especulativo, dos novos

${ }^{48}$ APPADURAI, Arjum. O medo do pequeno número: ensaio sobre a geografia da raiva. São Paulo: Iluminuras/ Itaú Cultural, 2009. 
instrumentos financeiros e das tecnologias de informação altamente velozes". ${ }^{49}$ Essa movimentação mostra a interferência direta na prática comercial, que ignora distâncias e impõe o que Jean-Luc Nancy nomeou de ideia reguladora ${ }^{50}$ à medida que o que sustenta o elo econômico, a operação tecnológica e a fusão política, num corpo ou sob um chefe, como representantes da ideia de comunidade se reduz como imanência mesma do homem.

O que aparentemente parece um grande voo rumo ao horizonte do mercado globalizado impõe ao contratado uma carga de trabalho, burocracia e disponibilidade para atender as exigências que dependem de outros fusos horários, descoladas do que se vive na realidade imediata, subordinada as diretrizes de algum $h u b$. Dessa forma, afasta-se essa população produtiva da atuação em prol da vida no entorno: planos diretores, canais de participação na agenda pública e associações dos mais diversos interesses, com seus desafios específicos e contextualizados no microorganismo do bairro.

Outro fator que varia de acordo com questões socioculturais, mas que em maior ou menor grau se expressam dentro dessa realidade, é a idealização de comunidades globais hegemônicas, alinhadas aos critérios de produção de bens e serviços, dispostas a tornarem-se receptáculos do sonho americano. Ele é disseminado pela indústria de consumo e se radicaliza ao fazer desse grupo uma força vulnerável ao totalitarismo, como veremos logo a seguir, num episódio que envolveu o presidente dos Estados Unidos, Donald Trump, e o presidente do Irã, Hassan Houhami.

A distância ganha um sentido paradoxal, pois as atividades locais ficam cada vez mais distantes dos que participam do modelo vertebrado do estado-nação. Mas o outro lado da moeda não poupa ninguém: são as restrições impostas aos que não optam pela adesão ao modelo e, portanto, sofrem sanções e são automaticamente considerados oposição a ele.

São grupos formados por ativistas, artistas, outsiders, educadores, líderes comunitários, ONGs, gente totalmente distante da força do capital especulativo, que funciona como contrapeso aos esforços totalitários dessa agenda global, que baliza índices de desenvolvimento, sem levar em consideração as diferenças socioculturais.

\footnotetext{
49 APPADURAI, Arjum. $O$ medo do pequeno número: ensaio sobre a geografia da raiva. São Paulo: Iluminuras/Itaú Cultural, 2009, p. 32.

${ }^{50}$ NANCY, Jean-Luc. A comunidade inoperada. Rio de Janeiro: 7Letras, 2016, p. 29.
} 
Entretanto, esses tipos de conexões globais pela via das operações comerciais remotas e conectadas, diferentemente dos tipos de atuação em rede que interessam à pesquisa, reafirmam o poder de alcance das empresas transnacionais através do capital que determina o distribuidor do budget e, por regime de meritocracia, o representante do hub -- o centro de conexão. Alimenta uma dimensão cultural que faz do capitalismo das marcas um padrão a ser perseguido em toda parte. No caso paulistano, a influência se espraia ostensivamente no mercado imobiliário e na publicidade, como vimos, na indústria cultural e no comércio em geral. Contamina o jeito de se ocupar as ruas, sinaliza o status de certos bens de consumo, prioriza a força produtiva como legítima representante do direito à cidade e aos bens culturais, mesmo que esses bens ocupem áreas tão complexas e com população local tão carente de acolhimento, como as periferias de grandes centros urbanos, no caso paulistano, a Luz

Como parte dessa estratégia, a mídia neoliberal protecionista, apoiada pelas grandes corporações, investe pesadamente no discurso do medo; no nosso exemplo, claramente responsável pela satanização da Cracolândia. Curioso é que mesmo em diferentes escalas fica evidente a aplicação dessas técnicas de controle da narrativa. É flagrante o que Appadurai detecta como uma lógica dupla para o que denominou ideocídio ${ }^{51}$ e civicídio: "globalizar opositores morais internos e trazer para perto inimigos morais distantes".

Em 2018, o presidente dos Estados Unidos, Donald Trump, proferiu um discurso na Assembleia Geral das Organizações Unidas (ONU), em Nova Iorque, atacando "a ditadura corrupta do Irã" e propondo sanções econômicas.

(...) O presidente americano abordou a relação com o Irã - já que os EUA abandonaram o acordo nuclear com o país. Disse que os líderes iranianos fazem parte de uma "ditadura corrupta" e buscam semear "caos, morte e destruição".

De acordo com Trump, diante desse quadro, os Estados Unidos lançam uma campanha de pressão econômica para impedir o acesso do Irã ao fundo para desenvolvimento regional. Pedem, além disso, que as nações aliadas isolem as lideranças iranianas, enquanto ainda houver agressões.

\footnotetext{
51 Sobre ideocídio, Appadurai revela um termo para "um fenômeno amplamente difundido, de fato global, um fenômeno novo e grave, em que povos, países e modos de vida inteiros são considerados perniciosos e estranhos à esfera da humanidade, além de alvos adequados para o que Orlando Patterson chamou de 'morte social' (1982)." APPADURAI, Arjum, op. cit., p. 88.
} 
Na tarde desta terça, o presidente do Irã, Hassan Rouhani, também aproveitou seu discurso na assembleia para criticar Trump. "O governo dos Estados Unidos, pelo menos essa administração atual, parece determinado a tornar ineficazes todas as instituições internacionais", disse Rouhani. "Confrontar o multilateralismo não é um sinal de força, mas um sintoma de fraqueza de intelecto. Revela uma inabilidade para entender um mundo complexo e interconectado." 52

No mesmo evento, o presidente dos Estados Unidos exaltou o patriotismo e rejeitou o globalismo, questionando a legitimidade da ONU. Aqui, o paradoxo do que Appadurai chama de "fantasia reinante de que o estado-nação garante um espaço econômico soberano" expõe a força conservadora na demarcação de direitos por legitimidade de sangue e ataques a todo tipo de diferença. Na estratégia do líder estatudinense, o patriotismo se coloca a serviço do modelo imperial e torna-se possível como marco protecionista para as lideranças econômicas.

Evidencia-se as mesmas disputas entre superpotências europeias ou asiáticas e entre zonas ricas e zonas pobres em todos os graus de escala. Reproduz-se nas cidades, nos bairros e nas calçadas. Trata-se de modelo. Funciona para a negociação da permanência e uso da identidade como direito a algum tipo de vínculo, na visão de Agamben, "como se a moral levantasse sempre as suas barreiras".

Traduzem o que menos nos interessa na possibilidade de apropriação da palavra neutralidade, ao reforçar o uso da força para garantir operações produtivas sem sustentar relações com a diversidade. Dentro dessa realidade, que enfraquece o relacionar-se no espaço da cidade como necessidade legitimadora da cidadania e da tolerância, "o que significa habitar um mundo interconectado digitalmente onde cada vez é mais difícil ser estrangeiro?”, pergunta Canclini.

Para responder, é necessário ter em conta, ao menos, três noções disseminadas na modernidade e pós-modernidade: A) a estraneidade como perda de um território próprio; B) a experiência de ser estrangeiro-nativo, ou seja, sentir-se estranho na própria sociedade; C) a experiência de sair de uma cidade ou nação que asfixia e escolher ser diferente ou minoria em uma sociedade ou

\footnotetext{
${ }^{52}$ G1.Mundo. Disponível em: https://g1.globo.com/mundo/5 set.2018.
} 
língua que nunca vamos sentir como inteiramente própria. ${ }^{53}$

Viver a estraneidade é um retrato dessa espiral que coloca em xeque uma ordem que até há muito pouco estava limitada à geopolítica mundial. Entretanto, nessa dança global real, virtual, não é mais possível reconhecer o "de dentro" e o "de fora" com um raciocínio elementar das barreiras culturais e físicas mais evidentes. $\mathrm{O}$ dentro e o fora abarcam questões como racismo, homofobia, transfobia, xenofobia, misoginia e outras violências que promovem segregação e a cultura do ódio. O avizinhar-se na contemporaneidade pressupõe o dentro e o fora de nós mesmos como algo possível de existir a partir da conexão direta com o dentro e fora do outro.

Seguimos com os aspectos que trilham um caminho das minorias, dos menores, na globalização de raiz proposta por Appadurai, na antropologia menor proposta por Viveiros de Castro, do liminoide criado por Turner, num corpo politico fragmentado como observa Safatle, nas passagens que marcam o pensamento de Walter Benjamin e, ainda, na literatura menor evocada por Deleuze e Guattari.

Todos esses conceitos são determinados pelo que Deleuze aponta como "um forte coeficiente de desterritorialização" e que nas literaturas menores vai ter como segunda característica "o fato de que tudo nelas é politico". ${ }^{4}$ São esses conceitos/coeficientes que sustentam a prática de acolher a diferença na base da amizade e toda a reflexão compartilhada na tentativa de pensar vizinhança como (des)semelhança, proximidade e amizade, nas relações abstratas, espaciais e sociais.

\footnotetext{
${ }^{53}$ GARCÍA CANCLINI, Néstor. O mundo inteiro como lugar estranho. São Paulo: Edusp, 2016, p. 59.

${ }^{54}$ DELEUZE, Gilles e GUATTARI, Félix. Kafka por uma literatura menor. Rio de Janeiro: Imago, 1977, p. 26.
} 
Parte 2 - Relações abstratas e espaciais de vizinhança 


\section{III. (DES)SEMELHANÇA}

\section{NO PARALELO DOS PODERES: CRACOLÂNDIA}

Nas duas últimas décadas, foi uma constante as investidas dos órgãos de segurança pública municipal e estadual para reprimir a permanência das pessoas em situação de rua, na região da Luz, especialmente os usuários de crack. Um discurso ambíguo que sempre se utilizou do combate ao tráfico de drogas e/ou da promessa de recuperação urbana da área, com os objetivos nunca alcançados. Diante da inoperância dessas tentativas, o que resultou na realidade foi a alcunha de "Cracolândia" ${ }_{55}$ para retratar o espaço, na zona central da cidade de São Paulo, marcado pela cena do consumo de crack. Cenário dinâmico, palco da errância dessa massa excluída, exemplo de um fenômeno diagnosticado por pesquisadores da área, num relatório que veremos logo adiante, como “territorialidade itinerante" [Frugoli Jr e Spaggiari, 2010].

$\mathrm{Na}$ primeira metade da década de 2010, já era possível constatar o histórico de empreitadas mal sucedidas na política de reurbanização da zona central e na agenda de iniciativas assistenciais aos usuários de crack. Naquele momento, a Cracolândia passou a protagonizar mais um conflito de interesses, envolvendo os poderes municipal e estadual; especificamente a partir de 2014, na gestão do prefeito Fernando Haddad, do Partido dos Trabalhadores (PT), com a criação do Programa "De Braços Abertos" (DBA), em contraponto ao programa estadual "Recomeço" da gestão Geraldo Alkmin, do Partido da Social Democracia Brasileira (PSDB).

\footnotetext{
${ }^{55}$ Mas é preciso ter em conta que a "Cacrolândia" está longe de ser um mero logradouro físico. Ela foi se alterando e se deslocando no decorrer dessas duas décadas, pelas imediações do bairro da Luz. As Ruas Guaianases, Triunfo, Vitória, Glete, Helvétia, Ana Cintra, dos Protestantes, dos Gusmões, dos Andradas e General Couto de Magalhães; o Largo General Osório, as Alamedas Dino Bueno e Barão de Piracicaba; trechos das Avenidas Cásper Líbero, Duque de Caxias, Rio Branco e Ipiranga; Praças Isabel e Júlio Prestes - todos são endereços das adjacências e concentrações dos usuários de crack. Rui, Taniele C. Corpos Abjetos: etonografia em cenários de uso e comércio de crack. Campinas. IFCH/Unicamp. Tese de Doutorado em Antropologia Social, 2012:190
} 
O plano na esfera municipal tentava tocar em dois grandes desafios: intervenção urbana na área degradada e a implantação de um programa de atenção e cuidado com os usuários de crack, até então inédito no país. Já a política estadual, segundo o secretário de Estado de Desenvolvimento Social, à época, Floriano Pesaro, apelava para o conceito de "Uma Vida Sem Drogas", ${ }^{56}$ que dependia da garantia de uma rede de proteção social, desde o governo até seus familiares.

Dentro dessa disputa por modelos programáticos, a proposta de priorizar a redução de danos na cena de consumo do crack, criada pela gestão Fenando Haddad, foi objeto de uma pesquisa na qual nos apoiamos para compreender aquele momento da vida, na região da Luz. O "De Braços Abertos" visava, sobretudo, a via da inclusão social. ${ }^{57}$ A experiência resultante dessa abordagem ecoou como um esforço de aproximação e diálogo entre agentes do poder público e o contingente de usuários da região. Esse foi o diferencial que vale ressaltar: os frequentadores da Cracolândia foram ouvidos.

Marco dessa empreitada, essa pesquisa fez uma avaliação do "De Braços Abertos" com apoio científico do Centro Brasileiro de Análise e Planejamento (Cebrap) e do Laboratório de Estudos Interdisciplinares sobre Psicoativos (Leipsi), apoio financeiro da Open Society Foundations e, para publicação, da Plataforma Brasileira de Política de Drogas (PBPD) e do Instituto Brasileiro de Ciências Criminais (IBCCRIM), em 2016. Com caráter interdisciplinar, contou com a coordenação da antropóloga Taniele Rui e consultoria do sociólogo Maurício Fiore e do psiquiatra Luís Fernando Tofoli.

Realizada no primeiro semestre de 2015, na Cracolândia, buscou conhecer o perfil dos beneficiários do programa e colher informações junto deles para verificar o impacto em suas vidas cotidianas e em seus hábitos de consumo de crack e outras drogas. O objetivo foi o de empreender a primeira avaliação sistemática, mesmo que limitada, sobre o DBA. ${ }^{58}$

Conhecer algumas informações coletadas nessa empreitada nos ajudará a compreender em que contexto adentrei nessa região tão complexa da cidade de São Paulo. O relatório ajuda-

\footnotetext{
${ }^{56}$ Disponível em: https://www.desenvolvimentosocial.sp.gov.br/a2sitebox/arquivos/documentos/1675.pdf22 dez. 2020.

${ }^{57} \mathrm{O}$ De Braços Abertos se assume como programa de baixa exigência, seguindo o modelo de Redução de Danos. ${ }^{58}$ https://pbpd.org.br/publicacao/pesquisa-sobre-o-programa-de-bracos-abertos/ Acesso em: 22 dez. 2020.
} 
nos no desafio de conhecer minimamente as características que predominavam nessa comunidade flutuante, no período que antecedeu a minha pesquisa e a presença do Diversitas no território da Luz: 2015-2016. Dado a extensão e complexidade do texto, optei por editar alguns trechos que no conjunto nos apresentam um retrato da época, um retrato da gente da Luz:

Metodologia

O universo da pesquisa são os beneficiários do DBA, conforme cadastro fornecido pela Prefeitura de São Paulo em 28 de abril de 2015. Nele, existiam 398 pessoas, dos quais 370 pertenciam à população-alvo da pesquisa: beneficiários com 18 anos ou mais (os menores de idade não são beneficiários, mas dependentes desses, já que o DBA não beneficia diretamente crianças e adolescentes). A unidade amostral era o hotel em que o beneficiário residia na data de acesso ao cadastro.

Para estimação da amostra, foi considerado para o cálculo um coeficiente de confiança de 95\% e um erro absoluto máximo de $10 \%$. Assim, obteve-se uma amostra factível para a pesquisa de 80 beneficiários.

\section{Perfil dos beneficiários}

O perfil da população masculina e feminina atendida pelo programa DBA, predominantemente, possuía mais de 30 anos, tinha filhos, declarava-se, em maioria como parda/mestiça, negra/preta, pouco escolarizada e proveniente do Estado de São Paulo.

Uso de substâncias psicoativas

Ao longo da pesquisa, mais de $65 \%$ dos beneficiários afirmaram ter reduzido o consumo de crack depois de ingressar no DBA e mais de 50\% disseram ter reduzido o consumo de tabaco e cocaína aspirada.

Saúde mental (Triagem de Transtorno Mental Comum TMC)

Vale apontar alguns achados nessa população, como a alta prevalência de sintomas de 'nervosismo', tensão e preocupação $(71,2 \%)$ da amostra, e tristeza $(67,2 \%)$, os itens mais frequentemente assinalados. Em relação a sintomas vegetativos, 42,2\% relatam terem dormido mal e 46,9\% informam terem falta de apetite, embora estes possam também ser efeitos colaterais do uso de crack. Quase um em cada cinco usuários (17,2\%) informaram que pensaram, no mês anterior, em terminar com sua vida (ideação suicida), um número preocupante e muito acima do que seria esperado na população geral, como demonstra um 
estudo feito no município de Campinas, que indicou a ideação suicida durante todo o ano anterior à entrevista como sendo de 5,4\% (Botega et al., 2009).

\section{Estado, Segurança e Justiça}

Igualmente, buscou-se saber a percepção dos beneficiários sobre os principais agentes públicos que atuam na região. As equipes do Programa Recomeço e do De Braços Abertos tiveram avaliação bastante positiva, enquanto os serviços policiais foram bastantes criticados. Deve-se notar que houve uma avaliação um pouco mais negativa da Guarda Civil Metropolitana e de seu destacamento de operações especiais (Inspetoria Regional de Operações Especiais, IOPE), ambos sob responsabilidade do município e mais atuantes no território, do que a Polícia Militar e mesmo a Polícia Civil, de responsabilidade do Estado.

\section{Avaliação do DBA}

Na pergunta genérica sobre o impacto do DBA na vida dos beneficiários, 95\% disseram que ele teve um impacto positivo ou muito positivo.

Em relação à controversa estrutura dos hotéis - um dos pontos que mais provocou conflitos e atenção midiática desde o início do DBA - foi levantado que $46 \%$ dos beneficiários consideram as habitações boas ou ótimas, 49\% avaliaram-na como regular ou péssima. Provavelmente, isso se deve às diferenças de estrutura e de higiene dos sete hotéis ativos durante a pesquisa, que eram bastante heterogêneos.

\section{Aspectos positivos do De Braços Abertos}

Um dos pontos positivos do DBA - o mais relevante - foi o fato de inserir trabalho, renda e moradia no horizonte dos beneficiários do programa, sobretudo porque isso representou uma guinada na forma como, até então, se lidava com os usuários de crack nesta região.

Ora, nesse cenário, implementar um programa intersecretarial discursivamente regido pela lógica da redução de danos, que, na prática, não exige a abstinência dos usuários e oferta de moradia, trabalho e alimentação, sem dúvida, é uma iniciativa inovadora e corajosa.

\section{Aspectos problemáticos do De Braços Abertos}

A cisão entre aqueles que usam a droga que querem se recuperar e pequenos traficantes que repassam poucas quantidades de crack, entretanto, apenas contribui para a potencialização do processo de encarceramento que, em si mesmo, é incapaz de impedir o comércio de drogas, mas é um dos motivadores da espiral de exclusão que produz a própria espiral de exclusão que, como foi visto na etapa quantitativa da pesquisa, faz com que a grande maioria dos beneficiários já tenha passado pelo sistema prisional. 
No curto período de implementação e operação do programa de redução de danos da gestão Haddad, três anos, o corpo técnico não teve tempo o suficiente para interpretar esses dados e promover uma revisão e aperfeiçoamento das práticas implementadas. O DBA encerrou seu ciclo de acordo com a tradição do poder público brasileiro, na qual a gestão sucessora aposta no apagamento e na descontinuidade do legado, com proposições intervencionistas para lustrar a vitrine partidária.

O notório esvaziamento das conquistas do Programa De Braços Abertos culminou com a precarização dos serviços de atendimento à população flutuante da Cracolândia e com o fechamento dos hotéis sociais ${ }^{59} \mathrm{Um}$ cenário no qual nem mesmo a rua pôde ser reconhecida como um espaço qualificado de mediação com os usuários, visto que o interesse pela desocupação da área se contrapôs às necessidades já postas por quem ocupava, e ainda ocupa aquele solo. Narrativa que insiste na estigmatização do dependente de crack em situação de rua e, também, dos moradores dos cortiços e prédios residenciais que convivem com a tensão social do lugar.

Nessa disputa pelo protagonismo político, surge o Projeto Redenção criado por João Doria, do Partido da Social Democracia Brasileira (PSDB), substituto de Fernando Haddad na prefeitura da capital paulista. Apesar da rápida passagem de Doria pela gestão do município, 2017-2018, que o projetou para a liderança do Governo do Estado, ele contou com seu vice e aliado, sucessor no poder executivo municipal, Bruno Covas, para garantir a continuidade do Projeto Redenção. Essa situação que garantiu uma transição estável, oposta à transferência da pasta na situação anterior Haddad x Doria, se deu tão-somente porque se tratava de uma substituição de nomes dentro do quadro do mesmo partido (PSDB). Importante é o fato de que mesmo com essa sintonia, a integração intersetorial nas esferas do Estado e do Município continuou bastante limitada.

A principal diretriz do Redenção é o incentivo à internação dos usuários de crack. A aposta na desintoxicação seria complementada por uma série de ações programáticas suportadas pela criação de uma rede de moradias monitoradas no município e uma rede de residências

59 Disponível em: https://g1.globo.com/sp/sao-paulo/noticia/prefeitura-interdita-mais-um-hotel-social-doprograma-bracos-abertos-na-cracolandia.ghtml. Acesso em: 22 dez. 2020. 
terapêuticas para a continuidade do tratamento, com o objetivo final de encaminhar os exusuários para a reinserção social por meio do trabalho. ${ }^{60}$

Somada à guinada na abordagem terapêutica, vieram as inúmeras tentativas de evacuação da Cracolândia, num rápido manejo para favorecer o resgate do projeto de reurbanização da área batizado de "Nova Luz", nunca implementado de fato. ${ }^{61} \mathrm{O}$ reflexo dessa disputa permanente da gestão pública, que teve, e tem, como pivô a política antidrogas, contribuiu para expor a fragilidade dos elos que sustentavam a rede de atuação da saúde e da assistência social na zona central, mesmo no que aparentemente seria uma oportunidade de ação conjunta de todas as instituições pertencentes ao Governo do Estado e a Prefeitura de São Paulo.

Entretanto, o acirramento do embate técnico metodológico, a despeito das legendas, reforçou o distanciamento das instituições atuantes e de seus respectivos quadros de servidores, com profissionais que lado a lado perderam a chance de agir conjuntamente em prol do direito à vida e do direito à cidade, para atender às demandas urgentes dessa população. Fato que é recorrente no histórico da Cracolândia e que ficou registrado na minha conversa com Marcelo Ribeiro, diretor do Cratod, em 2016.

O que conhecemos como "rua" e como "espaço público" na região da Luz, durante o período da minha experiência de campo, de 2017 a 2019, mostrou-se sujeito a todo tipo de interdição, investida e desmando por parte do próprio poder municipal. Tornou-se a realidade mais visível de uma área exposta à truculência do Estado, como no flagrante da violência cometida por um funcionário da empresa responsável pela limpeza pública, noticiado pelo jornal Folha de S.Paulo, em 13 de março de 2018:

Um morador de rua foi alvo de forte jato d'água na manhã desta terça (13) na Cracolândia, no centro de São Paulo, lançado por agente responsável pela limpeza rotineira da área a serviço da Prefeitura de São Paulo, sob a gestão João Doria (PSDB).

A ação agressiva para forçar a retirada do homem sentado na calçada foi exibida pela TV Globo.

60 Disponível em: https://www.tjmt.jus.br/INTRANET.ARQ/CMS/GrupoPaginas/105/1020/Principais diretrizes_do projeto_Reden\%C3\%A7\%C3\%A3o.pdf. Acesso em: 15 set. 2018

${ }^{61}$ A área da Nova Luz compreenderia 45 quadras no perímetro formado pela Rua Mauá e avenidas São João, Ipiranga, Cásper Líbero e Duque de Caxias. O projeto consolidado previa a transformação de $55 \%$ da área de superfície e $23 \%$ da área construída. Disponível em: http://g1.globo.com/sao-paulo/noticia/2011/08/prefeitura-de-sp-preve-para-2012-iniciodas-obras-do-projeto-nova-luz.html. Acesso em: 22 dez. 2020. 
O vídeo mostra que ele tenta se proteger com um cobertor do jato d'água, lançado por pelo menos 15 segundos em sua direção, até que duas assistentes sociais avançam para interromper a ação - registrada na Alameda Cleveland, por volta das 9 horas.

O episódio ocorreu durante operação de limpeza da região (são três a quatro por dia), que é feita com jatos d'água e é um dos principais instrumentos da gestão Doria para impedir que usuários de droga fixem barracas no local.

A estratégia de promoção dessa eugenia foi recorrente, tratava-se de dispersar os usuários de crack no pedaço equivalente ao quarteirão composto pelas Alameda Dino Bueno, no trecho entre as transversais: Rua Helvétia e Alameda Glete, já comprometida com a remodelação e a construção de um condomínio de classe média baixa.

Apenas um mês depois desse incidente, que repercutiu com as imagens mostrando o jato d'água no morador de rua, foi a vez do Governo do Estado pautar a imprensa com a notícia da reconfiguração dessa parte degradada da zona central. Segundo a reportagem publicada no site Veja São Paulo, em abril de 2018, a gestão do governador Márcio França, do Partido Socialista Brasileiro (PSD), que assumiu o cargo após o titular Geraldo Alckmin renunciar para disputar as eleições presidenciais ao final daquele ano, prometia um primeiro empreendimento naquela área, que levaria 170 famílias para um dos oito edifícios previstos, com torres que variavam de doze a dezessete andares, construídas pela Companhia de Desenvolvimento Habitacional e Urbano do Estado de São Paulo (CDHU). ${ }^{62}$

Naquele momento, repetia-se o alinhamento dos poderes estadual e municipal, no esforço de imposição de uma mudança: "a reurbanização de uma região inteira" como afirmava, na mesma matéria, o secretário estadual de Habitação, Nelson Beata.

Reurbanizar significa urbanizar de novo, reorganizar o espaço urbano compreendendo urbano como o que vive na cidade. E o que vive na cidade? Com se chega a essa resposta? A declaração que pretendia expressar uma ação capaz de atingir "uma região inteira" pressupõe, no sentido imediato do adjetivo inteiro, "todas as partes que lhe são próprias" e se desdobra no que não está quebrado, fendido ou deteriorado. E o que tem lugar nessa ética da inteireza? A arquitetura classista firmada por contrato entre o poder público e o poder privado. Falamos de

62 Disponível em: https://vejasp.abril.com.br/cidades/cracolandia-praca-julio-prestes-empreendimentohabitacional/. Acesso em: 22 dez. 2020. 
uma mesma classe que frequentou o mesmo conjunto de faculdades e que acredita ter o entendimento possível do que pode ou não viver na cidade. Do que tem ou não lugar.

Ainda, em 2018, aconteceram as chamadas da prefeitura, por meio da Secretaria Municipal de Urbanismo e Licenciamento (SMUL) e da SP-Urbanismo, sobre a extensão do prazo de participação na consulta pública do Projeto de Intervenção Urbana (PIU) do Setor Central de São Paulo. ${ }^{63}$ As sessões que acompanhei, invariavelmente, acumulavam queixas feitas pelas pessoas presentes sobre a linguagem inacessível das propostas apresentadas, seguidas de pedidos de desculpas pró-forma por parte do corpo técnico pelo uso dos termos do urbanismo. O flagrante de uma plateia passiva e assustada pelo medo de desapropriações explicitava a distância entre a intenção de uma consulta como ato ou efeito de pedir a opinião de alguém e o real alcance do convite para a participação.

Uma ausência de diálogo pela inabilidade geral para o reconhecimento do outro menos letrado e cidadão comum como interlocutor, coautor, como proponente e não apenas receptor acuado e deslocado do centro das decisões. $\mathrm{O}$ medo da desapropriação não era uma fantasia mórbida do futuro, se fazia realidade pelo não reconhecimento desses sujeitos presentes como proprietários de um conjunto de valores, verdades e experiências capazes de criar o "novo" na visão de quem conduz e não pode em hipótese alguma ser conduzido.

A sessão de consulta pública deveria funcionar como um conselho, um diálogo horizontal, uma troca de informações por parte de quem conhece e habita o lugar. Na realidade, assumia o acanhado papel de uma prestação de contas imprecisa, sem o tempo de implementação do que estava sendo proposto. Tratava-se de um teatro da ratificação, da confirmação. Quando muito de uma discussão com outros arquitetos representantes de órgãos de classe, comerciantes e advogados lobistas. Um intercurso entre o mesmo extrato social.

Nítido o desentendimento de como uma consulta pública poderia ser um ato pedagógico pela via de mão dupla. Incapazes de dialogar com as diferenças, com a diversidade, com o estrangeiro, reproduzia-se um projeto demagogo de cidade, sem promover uma aproximação com as realidades que escapam à força produtiva, na lógica de que essa é a que determina a ocupação e o uso do solo. Uma democracia que tem como chancela de pertencimento a visão economicista da polis e, a partir daí, regula o que é para existir e o que é para dissipar, expulsar.

${ }^{63}$ Disponível em: https://minuta.gestaourbana.prefeitura.sp.gov.br/piu-setor-central/m: 22 dez. 2020. 
Sobre o ter lugar, em A comunidade que vem, Agamben chama a atenção para o sentido da ética. Segundo o filósofo, é necessário compreender que "o bem não é nem pode ser uma coisa ou possibilidade boa ao lado ou acima de toda coisa ou possibilidade má, que o autêntico e o verdadeiro não são predicados reais de um objeto, perfeitamente análogos (mesmo se opostos) ao falso e ao inautêntico". ${ }^{64}$ A nossa pretensão de desejar a totalidade não pode estar condicionada a uma filtragem das impurezas do que elegemos para nos eleger, em ato contínuo, como protagonistas de um processo no sentido de realização prolongada do inteiro como domínio dos sentidos, do sagrado e da verdade.

Quase que nos escombros desse centro que fede, Agamben poderia sussurar um adágio filosófico: veritas patefacit se ipsam et falsum.

A verdade não pode manifestar a si mesma senão manifestando o falso, o qual
não é separado e rechaçado em outro lugar; ao contrário, segundo o
significado etimológico do verbo parfecere, que equivale a "abrir" e é conexo
a spatium, a verdade se manifesta somente dando lugar à não verdade, isto é,
como ter-lugar do falso, como exposição da própria e íntima impropriedade. ${ }^{65}$

A Cracolândia como oposto da inteireza é encarada como um pesadelo constante por parte de quem pretende tal reurbanização. Na descoberta da impossibilidade da "apropriação do impróprio" busca-se o que o filósofo italiano identificou como o movimento de remoção para outro lugar do mal rechaçado e, portanto, "a cada consolidação dos muros do Paraíso correspondia o aprofundamento do abismo infernal".

Naquele período, 2017-2019, a imprensa já apontava para um deslocamento literal do que era denominado como "Cracolândia". O termo se reinventava, também, para dar conta de novos sentidos. Já não delimitava apenas uma região decadente no centro da cidade de São Paulo, mas um conjunto de fatores que marcava o abismo infernal e expunha a exclusão social, a relação problemática com o consumo de crack e outras drogas, numa escala que começava a reproduzir-se em outros pontos da cidade. Reinventada em outra dimensão, a Cracolândia passou a ser denominada Microcracolândia, como retrata o infográfico a seguir. Um abismo

\footnotetext{
${ }^{64}$ AGAMBEN, Giorgio. A comunidade que vem. Belo Horizonte: Autêntica, 2013, p. 21.

${ }^{65}$ Idem, p. 21.
} 
reproduzido em escala a contrariar a lógica da geopolítica local e a espraiar-se como reflexo de uma bomba de gás de efeito moral, que recorrentemente fazia da violência a condição de dispersão.

Essa condição é a raiz das microcracolândias e das dobras possíveis nas vísceras da cidade, para que essas mulheres e esses homens de todos os gêneros e, sobretudo, de pele parda e negra encontrem algum tipo de aderência à vida. Como veremos logo a seguir, a invisibilidade traz a vizinhança da morte. Quem são os responsáveis?

Figura 8 - Infográfico apresentado pelo portal de notícia G1. Acesso em: 24 maio 2017.

\section{São Paulo tem oito cracolândias, diz Ministério Público}

Seis cracoländias estão concentradas na regiăo central; há ainda uma na Zona Leste e outra na Zona Sul. Promotoria também identifica outras dezenas de minicracolândias. como na Vila Leopoldina, Zona Oeste

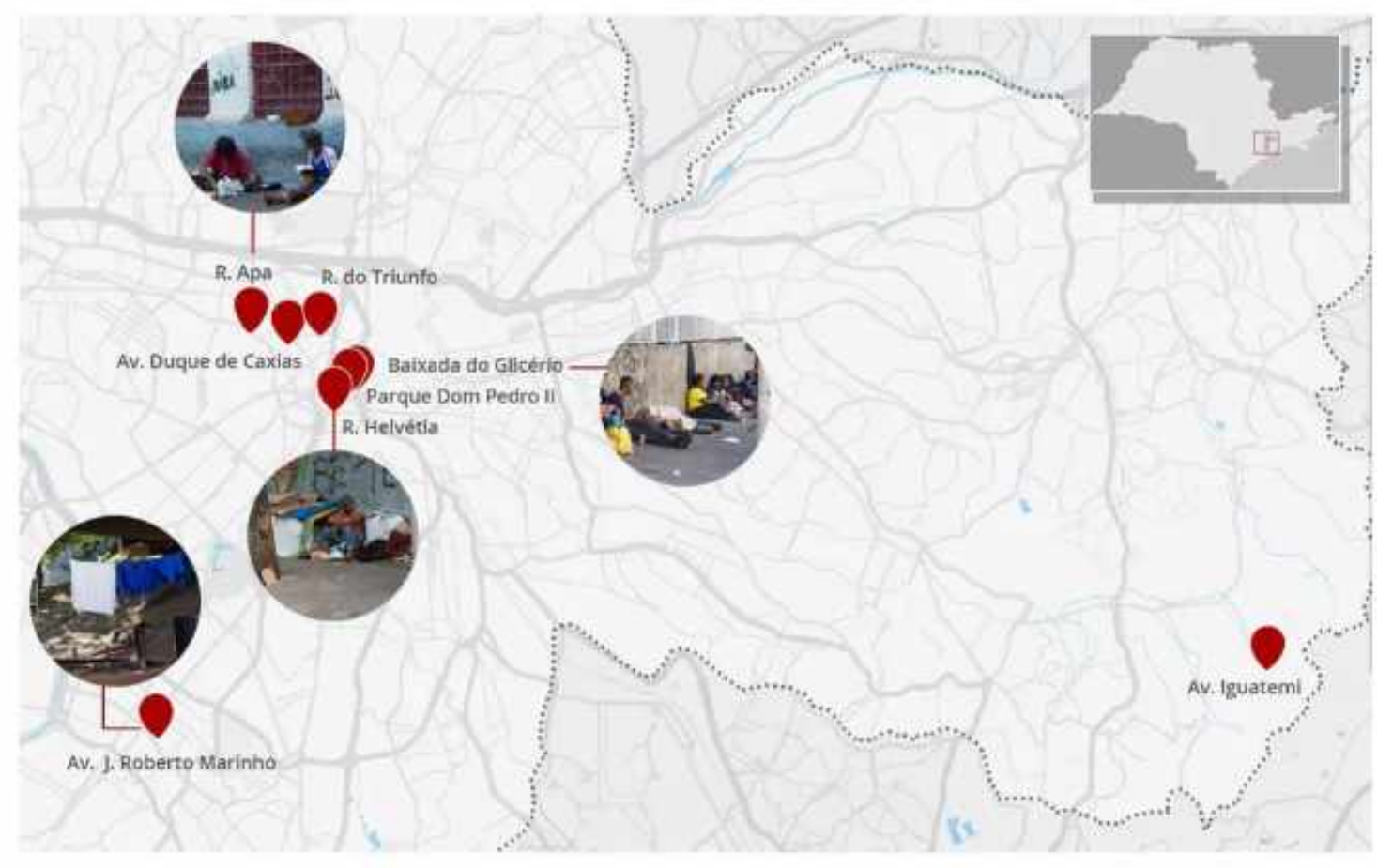

G1

A dispersão recorrente provocou uma errância dos usuários de crack na busca de outros locais para acomodação em diferentes zonas da cidade. Na região central, pudemos observar as 
alterações de configuração dessa diáspora: a marquise da Estação Pinacoteca, a Praça General Osório, a Rua do Triunfo, a Rua do Gusmões, dentre vários outros pontos do bairro da Luz, bem como outros bairros da mesma zona, tais quais: Bom Retiro, Campos Elíseos, República, Sé, Santa Cecília, Consolação, Pari, Brás, Barra Funda e Glicério.

\section{NO PARALELO DAS CALÇADAS: MICROCRACOLÂNDIA}

Retrocedendo mais um ano, em 2016, a Rua dos Gusmões abrigava, exclusivamente, um estacionamento da Guarda Civil Metropolitana (GCM) no número 43 - numa gleba bipartida em formato de cone, tendo como parte superior e mais ampla o limite com a Rua Mauá e o vértice inferior no encontro entre a Rua dos Protestantes e a Rua General Couto de Magalhães. 
Figura 9 - Imagem da Rua dos Gusmões, 43.

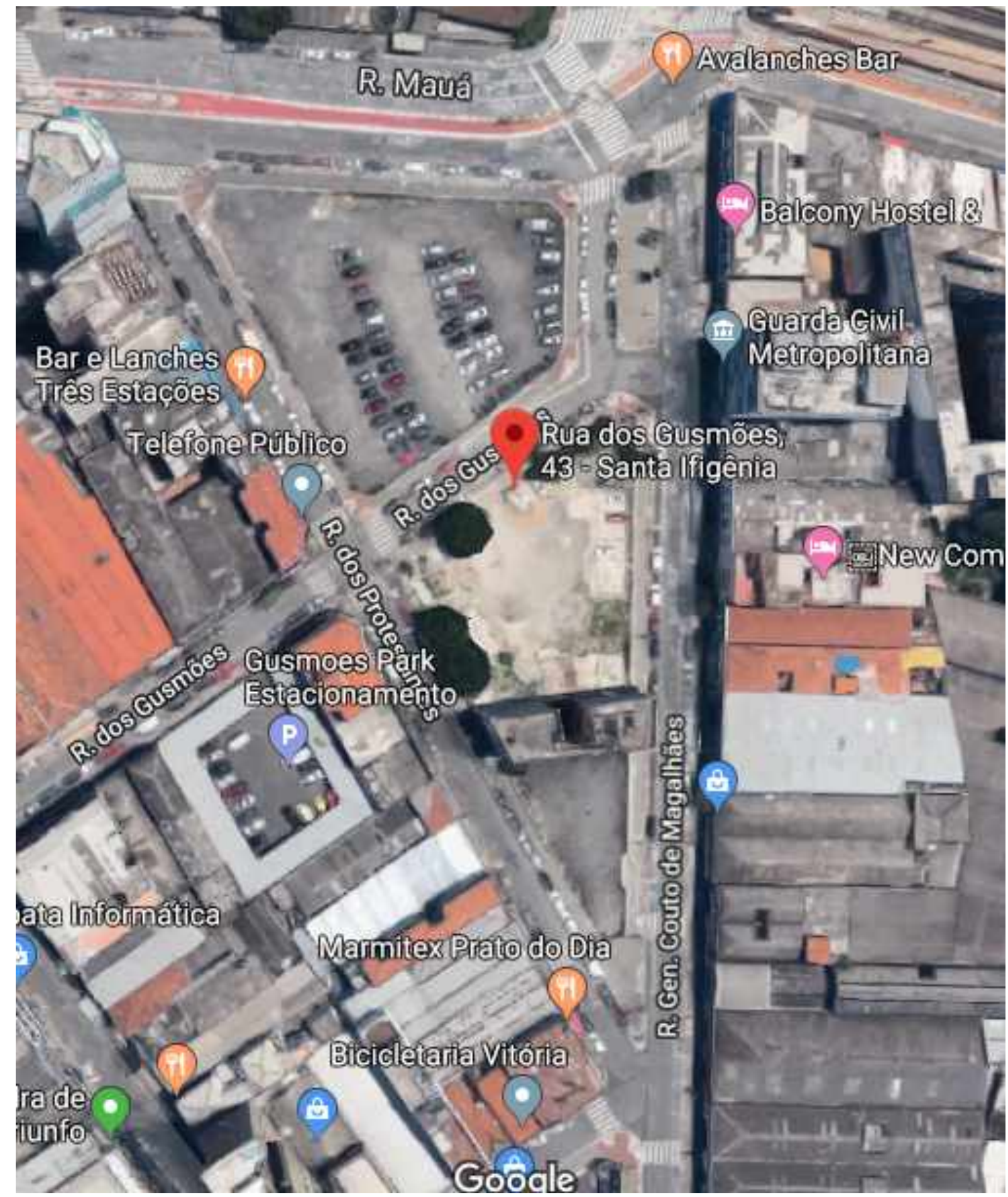


Ainda no final de 2016, nesse mesmo endereço - Rua dos Gusmões, 43 - os integrantes da Cia. de Teatro Mungunzá efetivaram uma ocupação considerada pelos próprios atores um ato político performático. A estratégia incluiu um pedido à prefeitura de concessão do terreno para a realização de um evento cultural durante dois meses. Liberada a licença, num ato de insubordinação civil, o grupo teatral executou um plano de ação que edificou um teatro como sede permanente para a Companhia, em apenas 48 horas. O prédio, feito com contêineres vindos do porto de Santos, fez surgir o Teatro de Contêiner da Cia. Mungunzá. Este passou a ser o novo endereço do grupo, que antes ocupava um galpão bem próximo, na Rua Prates, no Bom Retiro.

Caracterizada a ocupação cultural do endereço, o grupo se manteve instalado naquele pedaço da Luz. O Teatro de Contêiner consolidou-se na região como um polo de cultura capaz de articular uma ampla grade de eventos com a participação de outros grupos teatrais, artistas, coletivos, ativistas, inseridos ou não, na agenda da cidade.

Apenas em 2017, segundo dados fornecidos pelo grupo, aconteceram: 64 espetáculos adultos (com 272 apresentações), 11 espetáculos infantis (31 apresentações), 24 shows, uma exposição, 5 saraus, 8 festivais/mostras, 11 oficinas, 22 debates públicos, 4 festas, 5 lançamentos de livros, 5 espetáculos de dança, atingindo uma presença de público na casa das 50 mil pessoas.

A infraestrutura oferecia banheiros unissex, horta comunitária e uma generosa área externa de convivência que inclui uma geodesia que abriga vários encontros, um playground com brinquedos reciclados e uma miniquadra de futebol. Esses dois últimos foram pensados para a comunidade infanto-juvenil da vizinhança. Por todo o espaço é possível contar com mesas e cadeiras que sustentam a proposta de uma área de convivência, além de um bar no qual "paga-se o quanto achar justo".

Mais tarde, em 2017, no mesmo pedaço da Rua dos Gusmões, instalou-se uma das unidades do Atendimento Diário Emergencial da Prefeitura (ATENDE 1), com capacidade para acolher 400 pessoas em situação de rua. O galpão ficou de frente com a entrada principal do Teatro de Contêiner da Cia. Mungunzá, reconfigurando a situação de vizinhança do pedaço.

O ATENDE 1 continha um grande toldo branco projetado para proporcionar uma área de convivência, com cadeiras formando um ambiente de estar no qual uma das laterais contava 
com uma grande TV. O espaço ainda possuía um conjunto de contêineres pintados de branco para as instalações de serviços e do abrigo, dispostos pelo terreno, que servia ainda, na parte desocupada, de estacionamento para a Guarda Civil Metropolitana (GCM). Mesmo provisório, o ATENDE 1 marcou a presença da gestão pública naquele pedaço com um controle rígido de circulação e triagem, que simbolicamente refletiam-se na própria calçada. Esse lado da Gusmões era constantemente monitorado pela Guarda Civil Metropolitana, com a presença contínua e marcante dessa polícia municipal, devido à proximidade da sede da corporação.

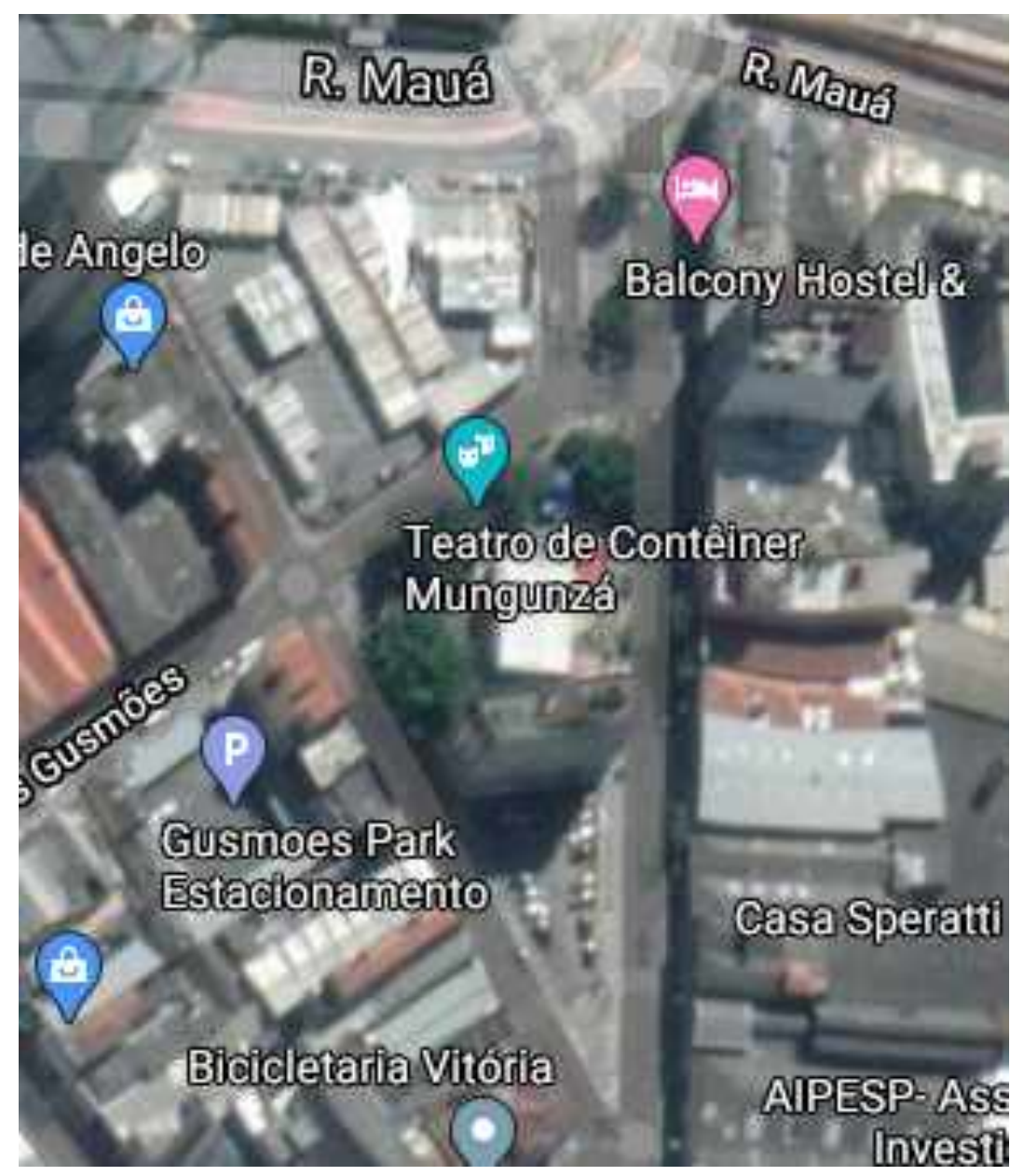

Do lado oposto, no número 43, a calçada do Teatro de Contêiner ficava totalmente ocupada por parte do mesmo perfil de usuários do ATENDE 1. Nesse lado ímpar da rua, a tela que protegia o espaço externo da Cia. Mungunzá, tal qual uma cerca, servia de suporte para 
tendas improvisadas com plástico, papelão e cobertores. Movimentação que transformou o passeio público num ambiente precário de moradia.

A proximidade desse trecho com a sede da Guarda Civil Metropolitana inibia o consumo de crack no pedaço. O fato contribuiu para que, colados à cerca da Mungunzá, o apelo fosse para o repouso após as incursões no fluxo.

$\mathrm{Na}$ calçada do teatro, enfileiraram-se camas improvisadas, pequenas acomodações e rodas de pessoas em situação de rua. Ali, eles apelavam para as dependências do teatro em busca de água filtrada, de boldo da horta, bem como para o uso do banheiro que também era partilhado pelo público dos espetáculos.

Apesar da rotatividade, parte desses moradores da calçada, acompanhava a rotina de movimentação nas dependências do teatro. Discretamente, estabeleciam algum tipo de contato com os frequentadores do espaço. Quando adoeciam, pediam ajuda. Eventualmente, assistiam à alguma cena de peça na calçada lateral ao teatro. Quando a Guarda Civil Metropolitana investia exigindo dispersão e desobstrução da calçada, eles saíam em pequenos grupos ou sozinhos pelo território da Luz até conseguirem retornar.

Essa dinâmica recorrente naquele período que lá frequentamos, 2017-2019, extrapolava as questões relacionadas à ocupação do espaço citadino, problematizava o que é público e o que é privado, quais as formas de controle que regulam a ocupação do solo e, principalmente, refletia a estratégia de dispersão geral dos usuários da Cracolândia, criando a "territorialidade itinerante" (Frugoli Jr e Spaggiari, 2010) das microcracolândias, como a calçada da Mungunzá. Numa instância mais radical, colocavam em xeque o próprio valor da vida, como pensa Agamben:

\begin{abstract}
A nossa vida política não conhece hoje outro valor (e, consequentemente, outro desvalor) que a vida, e até que as contradições que isto implica não forem solucionadas, nazismo e fascismo, que haviam feito da decisão sobre a vida nua critério político supremo, permanecerão desgraçadamente atuais. Segundo o testemunho de Antelme, de fato, aquilo que os campos ensinaram a quem os habitava era justamente que "colocar em questão a qualidade de homem provoca uma reivindicação quase biológica do pertencimento à espécie humana. ${ }^{66}$
\end{abstract}

66 AGAMBEN, Giorgio. Homo Sacer: o poder soberano e a vida nua I. Belo Horizonte: UFMG, 2010. p. 17. 
Diferentemente das características espaciais que determinam os campos de concentração como geopolítica substituta do estado-nação e determinantes de exemplares que vão das aduanas nos aeroportos ao quarteirão cercado e liberado para o uso de crack na região da Luz, a calçada da Rua dos Gusmões abarcava um paradoxo: o lado limpo e desocupado versus o lado sujo e povoado. Expressava uma cisão, como os muros e as zonas limítrofes dos sistemas de apartheid. Fazia parte da mesma lógica das áreas de confinamento e exclusão, mas operava em um sistema de opostos entre as calçadas espelhadas e incomunicáveis. Como as águas do Rio Solimões e do Rio Negro, que correm sem se misturar por conta das diferentes densidades de temperaturas, ao longo do percurso.

Nesse caso, as correntes que se arrastavam na Rua dos Gusmões criavam um traçado no qual o aparato estatal corria em paralelo ao constrangimento solidário do teatro: a vida nua dos homens passava sem barreiras e afetava as duas margens, porque ambos, Atende 1 e Teatro de Contêiner, estavam inseridos no contexto da Microcracolândia.

Não havia conflito entre os que conduziam o Atende 1 e os que mantinham o Teatro de Contêiner, existia um choque de mentalidades e o (des)entendimento de como lidar com esses desafios que esbarravam nos protocolos formais da organização social da saúde e nos arranjos afetivos da trupe teatral. O primeiro mais focado no atendimento em massa, o segundo improvisando conversas no rompante para tentar escutar cada indivíduo. Um asséptico e inóspito ambiente de abrigo de campanha, outro iluminado pelo colorido e vibrante espaço teatral. Ambos na provisoriedade e disposição de acolher quem fosse possível acolher.

$\mathrm{Na}$ calçada do teatro, podíamos enxergar um avizinhar-se do Atende 1 pela (des)semelhança, no sentido da aparência física dos atores e frequentadores e, também, na distância socioeconômica como limite da dessas relações abstratas com os técnicos da saúde. Nesse caso, sem chances de aproximação consistente entre ambos os vizinhos e com um tipo de solidariedade discreta, dentro da discordância dos métodos de abordagem e acolhimento da política pública vigente.

Os corpos dos frequentadores do teatro e dos moradores em situação de rua coexistiam na calçada, que fazia parte desse paralelo marginal, em oposição à calçada desértica que 
preservava a manutenção do status quo do Atende 1. Entretanto, esse endereço oficial era composto por pessoas comprometidas com a assistência e, nesse caso, com um tipo de capacitação e treinamento pensados para atender às demandas dos usuários. Não cabe aqui julgá-los pelo uso das diretrizes impostas pela gestão da organização social contratada e responsável pelos serviços de assistência, mas, ao contrário, observar o quanto o desafio de atender diretamente essa população os colocava no plano da ação que era desconhecido da maioria dos frequentadores do teatro.

"H", plantonista da noite no Atende 1, contou que, no marasmo da madrugada, protegido pela grade que separava o abrigo da Rua Mauá, ele presenciava todo tipo de situação no contexto de abandono geral.

Pessoas "radiadas" sob efeito do crack, crianças que moravam nas redondezas fumando maconha e pilhando moradores de rua em pleno sono, muitas brigas e até um esfaqueamento. Sem contar os inúmeros assaltos praticados pelas próprias crianças que, em grupo, abordavam os transeuntes. Muitos nas saídas dos hotéis que ficam próximos à estação da Luz.

Do lado da calçada do teatro, estava o que oscilava do invisível para o visível e viceversa. Numa interação que permitia ressaltar um tipo de solidariedade distante, um posicionamento mais afetado pela opinião do que pela ação. O contato dos visitantes e dos próprios artistas com os usuários de crack tinha esse grau de dificuldade na escuta, na fala, portanto, no diálogo.

O caminhar desses visitantes, considerados por muitos como representantes da gentrificação do pedaço, era claudicante. Enfrentavam obstáculos que, em sua maioria, eram corpos sonolentos misturados com utensílios domésticos e coisas coletadas nas ruas. Tudo ali naquela calçada.

De alguma forma, éramos obrigados a ziguezaguear pela rua para acessar a entrada do teatro. Na maior parte do dia, o portão constantemente fechado possuía uma tranca com cadeado falsamente trancado, que dificultava o acesso dos visitantes desavisados. Os que estavam por ali deitados, às vezes em roda conversando, acompanhavam a situação e vez por outra interagiam sutilmente: “Hoje, não tem ninguém aí... não?”, “Quer entrar?”, “Tem alguém lá atrás", "melhor dar a volta até aquele outro portão". Os que entravam no teatro o faziam sob 
essa pendulação de posturas opostas: o máximo de invisibilidade na rua até ultrapassarem o portão para ganharem o máximo de visibilidade na área do teatro.

Essa dinâmica expressava o alívio de deixar a cena dos usuários para trás, mesmo que o corpo ainda estivesse desaprumado pela condição do enfrentamento compulsório dos odores, do medo de qualquer tipo de situação na Cracolândia e, sobretudo, de se flagrar diante do olho que mata. Porque quando acontecia de um daqueles rostos olhar nos nossos olhos, reconhecíamos o que Vernant aponta como:

(...) frenesi do mundo dos mortos, Gorgó, que Perseu enfrentou antes de conseguir cortar sua cabeça. O que é fundamental nessa história é a forma como o grego entendeu a troca de olhares. Na verdade, trata-se de toda a teoria do amor tal como Platão a explica. O amor é o fluxo que parte de quem ama e que se reflete no olho daquele que é amado, de forma que vemos a nós mesmos no olho do outro; mas, para Platão, o outro que me ama vê em mim A Beleza, com letras maiúsculas, aquela que está muito além de mim. É a mesma coisa que Gorgó. Quando olho para ela, estou vendo a mim mesmo, ou, melhor aquilo que em mim já é o Outro. O que em mim está além de mim, não para o alto, mas para baixo. Vejo que em todo ser humano já existe a promessa de um caos irremediável. E isso que não é fácil de contemplar no olho de Gorgó, a morte de frente! ${ }^{67}$

Inúmeras vezes, ultrapassado o portão com o cadeado falsamente fechado, na excitação de reconhecer um dos integrantes da companhia ou qualquer outro conhecido no pedaço, uma frase complementar à saudação aparecia de forma recorrente quando nos encontrávamos ali:

"Hoje isso aqui está um caos".

Se num primeiro momento essa sentença instaurava uma cumplicidade entre os visitantes que buscavam um olhar conhecido, num plano mais sutil, a frase expressava uma (im)possibilidade de avizinhar-se sem constrangimento. Revelava o próprio estranhamento do estado das coisas na rua, no entorno e o choque entre a fantasia romântica de estar mais próximo dessa realidade e o contraponto à impotência diante do caos:

${ }^{67}$ VERNANT, Jean-Pierre. Entre mito e política. São Paulo: Edusp, 1996. p. 62. 
Caos está evidentemente relacionado com o v. xaíveiv (khaínein), "abrir-se, entreabrir-se", donde Kháos é "o vazio, a profundidade insondável (...) Caos é a personificação do vazio primordial, anterior à criação, quando a ordem ainda não havia sido imposta aos elementos do mundo". Ovídio, Met.1, 7, chama-o rudis indigesta que moles, massa informe e confusa. ${ }^{68}$

Ao considerarmos que o lado teatral da calçada da Rua dos Gusmões era a cerca que margeia a entrada da Mungunzá, essa linha de transição era um marco. O vazio, a profundidade insondável, cerca na qual deparávamo-nos com um tipo de sobrevida no seu movimento mais lento e apagado, a massa de gente informe e confusa ali grudada nas grades como uma praga urbana, os piolhos de cobra que se alimentavam de detritos, que comiam matéria vegetal morta e que quando se sentiam ameaçados, enrolavam-se fingindo-se de mortos. Experimentavam uma encenação do morar, do viver em situação de vizinhança com o teatro. Uma passividade que poderia ser vista como um apagamento, do tornar-se invisível para se reduzir à condição primeira da vida nua. E, nessas circunstâncias, tornavam-se vizinhos de fato ao habitarem o não-lugar no contexto do teatro social.

Acontecia que o jogo do ver-não-ver era criado em duas perspectivas: de quem estava ali deitado e de quem ansiava ultrapassar a situação para entrar no teatro. Um código imbricado que fazia da invisibilidade a condição de presença geral. Esse jogo do ver-não-ver permitiu também todo tipo de experimentação diante do que estava posto: o abandono da área. Situação ideal para a produção de uma agenda repleta de pautas sobre temas centrais no ativismo de esquerda, para mobilizar o meio artístico e para aprender com as dificuldades na lida com as pessoas que encontraram abrigo na cerca do teatro; tudo isso permitiu, sobretudo ao núcleo duro da companhia e seus principais parceiros, inventar uma vizinhança aberta ao diálogo.

O avizinhar-se pela (des)semelhança na Rua dos Gusmões paradoxalmente se dava por um tipo de paralelismo dos corpos que apareciam e sumiam, ora porque os que frequentavam a área entravam no teatro ganhando visibilidade e depois desapareciam nas regiões integradas da cidade, esquecidos do caos, ora porque os que compunham essa periferia, que margeava a borda do terreno, sumiam também, mas numa outra direção radicalmente oposta: seguiam para o

${ }^{68}$ BRANDÃO, Junito de Souza. Dicionário mítico-etimológico da mitologia grega. Petrópolis, RJ: Vozes, 1990. p. 182. 
fluxo. Morriam, ou simplesmente saíam para revirar o lixo em outras bandas à procura de recicláveis para revender ou de comida, como o trapeiro de Benjamin:

J68. 4

O trapeiro é a figura mais provocadora da miséria humana. Lumpemproletário num duplo sentido: vestindo trapos e ocupando-se de trapos. "Eis um homem encarregado de recolher o lixo de cada dia da capital. Tudo o que a cidade grande rejeitou, tudo o que ela perdeu, tudo o que desdenhou, tudo o que ela destruiu, ele cataloga e coleciona. Ele consulta os arquivos da orgia, o cafarnaum dos detritos. Faz triagem, uma escolha inteligente; recolhe, como um avaro um tesouro, as imundícies que, ruminadas pela divindade da indústria, torna-se-ão objetos de utilidade ou de prazer." ('Du vin er du bachisch'. Euvres, vol. I, p. 249-250; OCI, p. 381). Como se constata nesta descrição em prosa de 1851, Baudelaire se reconhece no trapeiro. No poema "Le vin des chiffoniers", OCI, p. 106, é apresentada ainda uma outra afinidade com o poeta, de forma explícita: "Vê-se um trapeiro cambaleante, a fronte inquieta,/ Rente às paredes a esgueirar-se como um poeta./ $\mathrm{E}$, alheio aos guardas e alcaguetes mais abjetos,/ Abrir seu coração em gloriosos projetos". ${ }^{69}$

Avizinhar-se pela (des)semelhança ganha esse outro paralelismo, o desse interlocutor invisível, inventariante do nosso lixo, capaz desse gesto de generosidade que é o de tocar nos nossos segredos misturados e apodrecidos. Conhecedor legítimo dos humores da cidade. Solitário que barganha consigo próprio o que é alimento, o que é encantamento e o que é escárnio. Com que tipo de humor reagimos diante dos catadores de lixo em plena ação? Eles têm esse poder de alcançar o cesto de roupas sujas da cidade, e nós ignoramos o que se revela nessa incursão. Mas Raduan Nassar nos faz lembrar:

(...) mas alguma vez te ocorreu? Alguma vez te passou pela cabeça, um instante curto que fosse, suspender o tampo do cesto de roupas no banheiro? Alguma vez te ocorreu afundar as mãos precárias e trazer com cuidado cada peça ali jogada? Era o pedaço de cada um que eu trazia nelas quando afundava minhas mãos no cesto, ninguém ouviu melhor o grito de cada um, eu te asseguro, as coisas exasperadas da família deitadas no silêncio recatado das peças íntimas ali largadas, mas bastava ver, suspender o tampo e afundar as mãos, bastava afundar as mãos pra conhecer a ambivalência do uso, os lenços dos homens antes estendidos como salvas para resguardar a pureza dos

${ }^{69}$ BENJAMIN, Walter. Passagens. Organização: Willi Bolle. v. 1. Belo Horizonte: UFMG, 2018. p. 579. 
lençóis, bastava afundar as mãos pra colher o sono amarrotado das camisolas e dos pijamas e descobrir nas suas dobras, ali perdido, a energia encaracolada e reprimida dos meigos cabelos do púbis, e nem era preciso revolver muito para encontrar as manchas periódicas de nogueira no fundilho dos panos leves das mulheres ou escutar o soluço mudo que subia do escroto engomando o algodão branco e macio das cuecas, era preciso conhecer o corpo da família inteira, ter nas mãos as toalhas higiênicas cobertas de pó vermelho como se fossem as toalhas de um assassino, conhecer os humores todos da família mofando com o cheiro avinagrado e podre de varizes nas paredes frias de um cesto de roupa suja; ninguém afundou mais a mão ali, Pedro, ninguém sentiu mais as manchas de solidão, muitas delas abortadas com a graxa da imaginação, era preciso surpreender nosso ossuário quando a casa ressonava, deixar a cama, incursionar através dos corredores, ouvir em todas as portas as pulsações, os gemidos e a volúpia mole dos nossos projetos de homicídios $(\ldots)^{70}$

Alguns possuíam um tipo de concentração na tarefa de vasculhar os cestos com as mãos e escutar com os dedos os segredos e desejos da cidade, com uma dedicação dos comprometidos com a produção de reciclados. Esses circulavam num traçado objetivo dos que já conheciam os pontos de coleta, os locais de possível aglomeração de latas ou garrafas tipo pet. Muito ágeis e concentrados, eventualmente eles indagavam sobre algum recipiente em cima das mesas, com uma discrição quase confidente: "Está vazia?".

Às vezes, a pergunta nem interrompia a conversa dos frequentadores da roda, às vezes alguém escutava aquela pergunta como se escuta algum segredo. Existia um cuidado quase protocolar por parte deles para não se fazerem presentes nessa indagação. Outra forma de apagamento, como se sustentassem, diante dos nossos olhos, o que não é tido como legítimo: a vida humana naquela condição. O evento podia ser festa, peça teatral, palestra, não importava. Não se perdia o foco que era, exclusivamente, os recicláveis. Geralmente carregavam sacos nas costas - que pousam no chão para abastecer mais objetos. Tudo ali era descartável, não possuíam objetos pessoais ou vestimentas que os devolvesse a ideia de continuidade e reuso, de lembrança ou conforto. De presença.

\footnotetext{
${ }^{70}$ NASSAR, Raduan. Lavoura arcaica. 3. ed. São Paulo: Companhia das Letras, 1997. p. 45.
} 
$\mathrm{Na}$ dinâmica geral desses espaços nos quais circulavam, já eram assimilados e nunca encaravam seus interlocutores quando interagiam, não causavam estranhamento quando presentes. Ao contrário, passavam despercebidos, eram invisíveis e não ameaçavam. Poderiam ser latas de lixo animadas, prestavam um serviço à própria sobrevivência e como sujeitos, quase sempre negros, expressavam um estado geral de degradação perfeitamente compatível com a miséria que os definia como sub-raça colonial. Não viraram paisagem, já eram figuras neutras no cenário brasileiro de brancos letrados e superintegrados.

Dos que surgiam da rua e investiam no pátio do teatro, um homem chamou minha atenção pelos gestos que eram muito lentos, quase sutis ao revirar o lixo, pelas roupas que estavam quase pretas de tão encardidas, na pele negra também muito suja e, sobretudo, pelo odor que exalava. Para além do previsível, na precariedade da situação de rua e na falta de acesso a direitos básicos, o odor muito forte, como o de uma carniça, comunicava a condição que lhe reservava somente o contrário do direito à vida. Um corpo ameaçado de desaparecimento, indiferente à degradação da matéria orgânica e à deterioração moral como indivíduo.

Homem que me fez lembrar fortemente o mulçumano de Primo Levi, a figura no campo de Auschwitz mais próxima de um não-homem que experimentavam um silêncio: "já se apagou neles a centelha divina”. Esse tipo denominado mulçumano dentro do campo pelo autor italiano não possuía a malícia, como os judeus mais articulados, para se tornar empreendedor na dinâmica da sobrevida, no nosso caso, um empreendedor de reciclados da Luz. Tanto um, na concentração exterminadora dos anos 1940, quanto outro, na diáspora da Cracolândia, não lutavam contra a morte, porque "estão esgotados demais para compreendê-la". ${ }^{71}$

Como se esse homem negro operasse numa outra dinâmica, na qual uma linha tênue tivesse sido ultrapassada e a intimidade com os detritos expressasse um tipo de fusão. Tal qual observou Philip Roth em entrevista com o próprio Primo Levi, no apêndice de outro livro do autor italiano: A tabela periódica. Roth, ao comentar: É isto um homem? "pelas formas com as quais um homem pode ser transformado ou desagregado, e pode perder suas propriedades características, como uma substância que se decompõe através de uma reação química." (Levi:2001). No caso do catador de lixo, circulando no pátio do Teatro de Contêiner, a sinistra

\footnotetext{
${ }^{71}$ LEVI, Primo. É isto um homem?. Rio de Janeiro: Rocco, 1988. p. 91.
} 
experimentação no laboratório social da exclusão e do extermínio explicitava a condição da pele preta desde a escravidão que assolou esse país. Exemplo brutal do que Achille Mbembe definiu como a condição de vida do escravo que "em muitos aspectos, é uma forma de morteem-vida". 72

O catador alquimista da Luz, assim como o mulçumano de Auschwitz e o escravo colonial, na sua procura contínua de qualquer coisa para mimetizar o teatro social do qual já não fazia parte, experimentava o limbo desse lugar: a vida no podre da cidade. Absorto na transmutação desses resíduos que a capital bandeirante devolvia pela violência do consumismo, engajava-se numa acumulação de toda sorte de itens deteriorados que, quando ainda aptos para seus primeiros destinatários, já expunha um registro de baixa qualidade: roupas sintéticas, snacks clandestinos, móveis quebrados, revistas antigas, sapatos imprestáveis etc.

Outro flagrante foi o de um desses alquimistas experimentando toda a sorte de restos de comida com a mão em concha direto para a boca, um tipo de mistura aquosa, um chorume represado na borda de um saco de lixo preto. Gesto contínuo de retirar o que estivesse ao alcance dos olhos e da boca, naquele amontoado de detritos junto a um poste de energia elétrica. A cena impossibilitava qualquer reconciliação com o discurso. Experimentava-se outra coisa: a transposição de um limiar.

O episódio deu-se como algo que instaurou uma experiência sem paralelos e imprimiu um tipo de silêncio que desconhecia na minha vida, como manifestação da vergonha de constatar que aquela existência expressava o resultado das múltiplas violências, no país no qual nasci e cresci, a começar pela "perda do lar, perda de direitos sobre o seu corpo e perda do estatuto político", 73

O flagrante desse acontecimento, nesse microuniverso, a retenção dessa primeira imagem, não se deu de forma destacada na qual seria inevitável ver o que se evita enxergar. $\mathrm{O}$ evento aconteceu diante de muitos, na insistência banal da rotina sub-reptícia da miséria do centro. Mas, no meu caso, detonou um estado de coisas que se manifestaram à medida que permaneci disponível para a não ação; fosse pelo espanto ou porque nunca queremos conhecer esses códigos.

\footnotetext{
${ }^{72}$ MBEMBE, Achile. Necropolítica: biopoder, sobrerania, estado de exceção, politica de morte. São Paulo: n-1, 2018. p. 29.

${ }^{73}$ Idem, p. 27.
} 
Vê-lo sorver o chorume do saco de lixo preto com a mão em concha e uma lentidão no gesto só compatível com o prazer de uma iguaria e não com a agilidade de botar para dentro algo sabidamente ruim, trazia uma outra informação. Delirante, em estado de consciência alterado, ele, o catador alquimista, não queria mais saber do barulho também. Sem nenhum ato de fé salvacionista, busquei chegar aonde era meu limite naquela vizinhança: o silêncio. Um recuo silencioso frente ao "estatuto dos mortos-vivos" como nomeou Mbembe.

Incapacitado de seguir como antes e sem ter o que dizer, permaneci com as expressões rotineiras de convivência e as sintaxes acadêmicas sobrando na boca. Tomado de assalto, passei a considerar a possibilidade de formulação de uma outra gramática, de uma língua silenciosa porque não encontrou palavras para levar adiante "a ideia de um progresso de humanidade na história", ao contrário, como nos aponta Benjamin, esse progresso é inseparável da ideia de sua marcha no interior de um tempo vazio e homogêneo. O filósofo alemão nos propõe a pensar "um tempo saturado de "agoras" passível de ser explodido do continuum da história. Apresenta a imagem do salto do tigre em direção ao passado "ele se dá numa arena comandada pela classe dominante. O mesmo salto, sob o livre céu da história, é o salto dialético da revolução, como o concebeu Marx". ${ }^{74}$

Remeter ao passado como uma sucessão de "agoras" para resgatar os momentos de cisão e violência como possibilidade de atuação. Não coube a tentativa de protestar e resolver aquele caso isolado, não coube lançar mão de recursos para mobilizar pares em prol de interferir com o propósito de reverter aquela situação. Coube apreender e aceitar o desmonte de um estado geral de coisas como uma implosão.

A região da Luz como campo de pesquisa também é o campo de concentração dos usuários de crack, também é o Campus da Universidade de São Paulo nas aulas públicas, também é campo grande da lavoura colonial desses homens e mulheres negros invisibilizados. Como potência, estado de intensidade, devir campo, toda essa simultaneidade se abre para essa outra gramática que persigo, que me esforço para vizinhar e que não está carregada do sentido dominante. Por isso, o seu caráter literário está em dar-se pela escuta do homem, do lixo, de outros sons, de outras falas, de outros risos. Nunca pela naturalização ou banalização dos

\footnotetext{
${ }^{74}$ BENJAMIN, Walter. Obras escolhidas, v. I, Magia e técnica, arte e politica. São Paulo: Brasiliense, 1994. p. 230.
} 
dizeres, mas pelo alargamento desse silêncio inquieto que me permite ampliar a permanência dentro de várias tensões.

Como Deleuze e Guattari pensam em $A$ metaformose de Kafka, ${ }^{75}$ no caso do catador alquimista, não há mais homem nem lixo, já que cada um desterritorializa o outro, numa conjunção de fluxos, num continuum reversível de intensidades. O que o lixo produz é um lugar que é receptáculo inclusive do homem. Não há como jogar o lixo fora sem descartar o homem que também já é o lixo, num fora que já esbarra em outro estado de coisa, no extremo da borda: o desaparecimento da vida. E nessa pendulação homem-lixo, lixo-homem, os cinco sentidos operam num diálogo entre matéria e corpo sem metáforas possíveis.

Ação que comunica a violência estrutural da sociedade brasileira presente desde antes, em todo o tempo que o descarte humano foi engendrado na economia que nos sustenta. Ouvese quase sempre o mesmo revirar dos plásticos e de outros volumes chacoalhando, ouve-se essa contínua escavação no interior das cestas de lixo, busca interminável por qualquer coisa que opere como labor, como lavoura, como germinação e vitalidade no escuro desses buracos que são depósitos públicos. Ouvem-se lamentos também. Quantas vezes na calada da noite, ouvese um desses homens cantando enquanto mergulha a cara nessas bordas.

Barulho que remete a uma constante escavação na região da Luz, como se essas figuras trouxessem à tona as memórias escravagistas e mantivessem através desse lixo revirado a ressonância das ossadas residuais oriundas dos maus tratos, da fome, das condições inumanas. Percutem o que sobrou do garimpo da memória nesses lamentos.

No extremo oposto dessa operação subreptícia, que no centro da cidade de São Paulo se desdobra em cada esquina, inúmeras vezes ao dia e mais audíveis e performáticas à noite, na outra ponta, na brecha que permite a inércia sem muita justificativa, no silêncio desenhado num amontoado de trapos num ponto qualquer das calçadas, ouve-se nada, enxerga-se nada. E lá está o homem amorfo, volume coberto no meio da rua.

Caminhar naquele pedaço, suportar a náusea e o asco do que nos é tão familiar e estranho ao mesmo tempo, experimentar a impotência diante dessas situações, talvez, fosse a possibilidade de não conformidade. A necessidade de revisitar esse território e lidar com a

${ }^{75}$ DELEUZE, Gilles e GUATTARI, Félix. Kafka por uma literatura menor. Rio de Janeiro: Imago, 1977, p. 34 
distância intransponível dessa vizinhança. Mesmo que essa tentativa de aproximação se desse repleta de equívocos por parte dos que reagiam automaticamente querendo tomar alguma providência salvacionista, quixotesca, completamente compreensível para quem se descobria naquela terra ignota.

$\mathrm{Na}$ urgência da rua, sucumbimos ao embaralhamento de códigos e à compreensão de que tudo é "imediato-político" na cidade. Tudo se inscreve numa duração que não pretende continuidade. Esse tempo tem a ver com a intensidade que aproxima quando "o sentido é ativamente neutralizado" e resta apenas os estados intensivos no território de coexistência. Como apresentam Deleuze e Guattari citando Wagenbach:

a palavra reina como senhor, dá diretamente nascimento à imagem. Mas como definir esse procedimento? Do sentido, subsiste apenas aquilo com que dirigir as linhas de fuga. Não há mais designação de alguma coisa segundo um sentido próprio, nem atribuição de metáforas segundo um sentido figurado. Mas tanto a coisa como as imagens não formam mais uma sequência de estados intensivos, uma escala ou um círculo de intensidades puras que podem ser percorridas em um sentido ou outro, de cima para baixo ou de baixo para cima. A imagem é esse próprio percurso, tornou-se devenir: tornar-se-cão do homem e tornar-se-homem do cão, tornar-se-macaco ou coleópetro do homem, e inversamente. Não estamos mais na situação de uma língua rica comum, onde, por exemplo, a palavra cão designaria diretamente um animal e se aplicaria por metáfora a outras coisas (das quais se poderia dizer "como um cão"). ${ }^{76}$

Diante dos acontecimentos na Luz, a língua dobra-se à medida que a escrita se dá com os sentidos na cidade, quando ela se faz incerta e oprimida. Qualquer tentativa de descolamento da realidade impede o avizinhar-se porque se torna superficial, porque escapa a "um agenciamento coletivo de enunciação", produzindo apenas a circulação de ideias "do que deveria ser feito", de "como era", “do que não pode ser". Nesses casos, essas ideias inserem-se na disputa pela narrativa que cabe como "a narrativa" do território.

Avizinhar-se pela palavra como um território de coexistência, mas sem produzir um discurso panorâmico, um leito conceitual como rede de proteção, sem elencar uma renca de casos para embasar o que é puro transe e ricocheteia na força da violência. Utilizar-se dos

${ }^{76}$ DELEUZE, Gilles e GUATTARI, Félix, op. cit. p. 34. 
conceitos para tocar nas arestas. Deixar o outro falar para encontrar um gancho, para juntar-se na prosa, para espreitar uma brecha, para expressar atenção ao que esse outro tem a oferecer naquele momento, naquele movimento. Como correr na plataforma e se jogar na última fresta da porta aberta do trem. Ninguém vai querer saber o que te leva a esse ímpeto, qual o motivo de arriscar-se. O que se produz na reflexão dessas experiências são as forças que imprimem pela escrita a transmissão de um ritmo. Avizinhar-se no silêncio da microdiversidade, numa viagem sem controle de direção, diluído no que o coletivo da metrópole paulistana diz de maneira insuspeita.

Escrever como um cão que faz seu buraco, um rato que faz sua toca. E, para isso, encontrar seu próprio ponto de subdesenvolvimento, seu próprio patoá, seu próprio terceiro mundo, seu próprio deserto. ${ }^{77}$

A descolonização do pensamento passa pela experiência insubstituível desses flagrantes que deslocam qualquer tentativa de apropriação e remetem aos estados de intensidade que não permitem lidar com outra coisa se não com a própria coisa em si.

O que é chamado de menor, na experiência que compartilhamos, tem a ver com o caminhar, escutar e agir pelo silêncio. Mas sobretudo tem a ver com o que Deleuze e Guattari defendem como a "desterritorialização da expressão".

Alguns ainda protegidos pelos protocolos institucionais, pelas falas técnicas do serviço social, da saúde, da polícia, alguns entoando o cântico das queixas sem atenção aos outros acordes possíveis para chegar mais longe, em ambos os casos se tornam mais criativos e parceiros quando abandonam esses gatilhos. Outros, conseguem se lançar com a curiosidade exploratória que minimamente altera o próprio estar ali.

Existe uma língua geral é a língua da fome. Durante uma conversa numa tarde, com “D”, usuário e morador do Hotel Social Zezinho 2, pude ouvir repetidas vezes o roteiro do seu dia, que se pautava pela agenda de comida ofertada por grupos de caridade e pelo serviço de assistência social do município. Uma escala capaz de encaixar, do café da manhã ao jantar,

\footnotetext{
${ }^{77}$ Idem, ibid. p. 28.
} 
todos os destinos no centro da cidade de São Paulo que garantissem comida e, em muitas das vezes, com horários passíveis de promover uma repetição de refeições em instituições distintas. Comemorado com êxito: dois lanches da tarde, dois jantares, comparando a melhor sobremesa entre um endereço e outro.

"D” partilhava as estratégias para se posicionar e conseguir os itens nobres dos cardápios que "acabavam primeiro" à medida que os pratos eram servidos. Um dos segredos era disciplina e, por conseguinte, uma pontualidade muito bem administrada. Descrevia com riqueza de detalhes as dinâmicas de cada endereço: fila, distribuição de lugares, tipo de frequentadores, diferentes pratos, cada salada, cada "mistura". À medida que ia falando, saboreava com gemidos e com um excesso de saliva que, vez por outra, espargia com naturalidade da sua boca.

Era sobre comida, mas era sobre muitas outras coisas. Era sobre habitar um espaço atravessado por violência e por campos de forças antagônicas na disputa pela legitimidade de viver naquela região. Através das suas digressões, muitos outros ingredientes compunham aquele banquete: primeiramente estar vivo e estar com disposição para comer o dia. O carinho de "D" pelo próprio estômago. Quem falava comigo era a barriga em depoimento livre, mostrando-me o centro a partir do seu próprio senso de sobrevivência e humor: como fazer um bom uso das políticas públicas, do assistencialismo, como flanar pelos restaurantes sociais e ser voluntariosa e gulosa. Como fazer um programa diferente e dar uma escapada até a "zona chique da Paulista pra descolar um rango de primeira". Como fazer dessa fartura a alegria que preenche o buraco do mundo e se contrapõe à escassez dos dias inapetentes no limbo do crack.

A pança, a pancinha cheia, um tipo de gravidez para parir outra vida dentro daquela que carrega as anteriores que preenchiam a história daquele corpo, que já teve casa e brigou com a família, que achou na rua o consolo da pedra de crack, que carrega num dos olhos a sequela da bala de borracha que explodiu num deles, no enfrentamento com a polícia na Cracolândia. Barriga que carregava o sujeito que se autodeclarava dependente químico, mas com desejo de mudanças na dinâmica do consumo de crack: depender menos, dormir mais, acordar para passear com a barriga. Mais forte, pensar em trabalhar: "bora trabalhar!".

Vizinhança é atentar-se para outros estados de coisas que atravessam a duração desses encontros, nos quais se almeja a criação de um campo afetivo também. E quais são os arranjos 
que articulamos para a expansão e sustentação desse expressar-se livremente? Não há respostas porque seriam falsos acordos, assim como todas essas situações relatadas devolvem uma impressão sempre reduzida do que foi viver a vida e, na melhor das hipóteses, contribuem com uma nova carga de tinta para reescrever o que quer que brote como expressão do vivido. Mas esse carregamento é importante porque ele deve circular como uma pista, um bilhete, uma exclamação. O avizinhar-se como "um faro para o atual, onde quer que ele esteja na folhagem do antigamente", como complementa Benjamin ainda, Sobre o conceito de história. ${ }^{78}$ A língua é nossa e só a encontramos na possibilidade do locomover-se para sobreviver.

\section{TAMBORES DA LUZ}

Numa das primeiras aulas do nosso Núcleo de Estudos da Diversidade, Intolerância e Conflitos, mais conhecido como Diversitas USP, começávamos uma das nossas importantes parcerias na Luz: com a Cia. Pessoal do Faroeste. Foi lá, na caixa preta do teatro, situada na rua do Trinfo, que encontramos "R".

"R", músico, usuário de crack, começou uma performance oferecendo-nos pequenos galhos secos com alguns filetes de raízes, radículas, nas pontas. Explicou que esses galhos representavam a forma que ele e outros usuários eram vistos pela sociedade. "Como se fôssemos plantas secas e mortas, sem nada a oferecer, enterradas na terra morta".

Entretanto, disse que ninguém enxergava que embaixo desses galhos retorcidos e mortos cresciam microfiletes de novas raízes e que essas radículas se tocavam num tipo de rede, num tipo de energia vital. Não estavam mortas. Estavam aparentemente mortas, mas se rearticulavam no invisível para sobreviverem.

Entre os vários caminhos para pensar nessas raízes múltiplas, primeiramente podemos entender a etimologia da palavra raiz, segundo o dicionário Houaiss, em gramática histórica, como o mínimo segmento lexical de uma língua antiga, documentada ou reconstruída pelo

\footnotetext{
${ }^{78}$ BENJAMIN, Walter, op. cit. p. 230.
} 
método comparativo, que teria dado origem às formas posteriores de uma ou várias línguas aparentadas; ou, ainda, no mesmo verbete, em anatomia, como o ponto onde o nervo se destaca dos centros nervosos; avançando ainda na morfologia botânica, como o eixo de uma planta vascular, que se desenvolve a partir da radícula, geralmente descendente e subterrâneo, frequentemente com ramificações secundárias, e que serve para fixá-la a um substrato, além de absorver e conduzir água e minerais. Por radícula, mais especificamente podemos entender como parte do embrião das plantas com semente que dá origem à raiz primária.

"R", primeira letra do nome do músico, e "R" como primeira letra de raiz e radícula, permitiu-nos chegar a um outro plano no qual o centro nervoso do centro de São Paulo acontece em ramificações secundárias, aparentemente inalcançáveis aos olhos dos paulistanos integrados e que não circulam naquela parte da cidade, desconhecem as dinâmicas na região da Luz.

Tais ramificações revelaram-se para o grupo, naquela noite, pelo som que "R" produzia a partir das sucatas coletadas nas suas andanças pelo centro: um pinico, tampas de panela, pratos etc. No ambiente do teatro, enquanto falava e produzia frases musicais, experimentávamos sensações contrastantes como a aspereza dos filetes que segurávamos nas mãos e, também, a delicadeza do som capaz de devolver-nos uma língua aparentada sobre a condição humana no mínimo da raiz comum de vizinhança. Não mais como algo que fixa um ponto, mas como um conector de heterogeneidades, um rizoma.

Um rizoma não cessaria de conectar cadeias semióticas, organizações de poder, ocorrências que remetem às artes, às ciências, às lutas sociais. Uma cadeia semiótica é como um tubérculo que aglomera atos muito diversos, linguísticos, mas também perceptivos, mímicos, gestuais, cogitativos: não existe língua em si, nem universalidade de linguagem, mas um concurso de dialetos, de patoás, de gírias, de línguas especiais. ${ }^{79}$

O que "R" partilhou na aula foi um "um diagrama intensivo" do funcionamento dessa multiplicidade, não como um tipo de identidade, mas como "um agenciamento de devires, um entre": um diference engine, ou antes o diagrama intensivo de seu funcionamento. Se

${ }^{79}$ DELEUZE, Gilles e GUATTARI, Félix. Mil platôs: capitalismo e esquizofrenia 2, São Paulo: Editora 34, 2011. p. 23. 
lembrarmos o sentido de diagrama musical como escala ou quadro que apresenta simultaneamente à vista a extensão geral de todos os sons compreendidos num determinado sistema, o que apreendemos naquele evento foi a composição de um território possível de ser coabitado a partir dessas línguas aparentadas: som, corpo, planos de interação (" $R$ " estava no chão e todo o restante sentado em cadeiras em volta dele), instrumentos compostos com os recursos do lixo da cidade, estados alterados de consciência pela textura sonora e pela composição espacial cênica da caixa preta do teatro. Escutávamos o que o pinico tinha a dizer, bem como as tampas de panelas e pratos; menos como objetos e mais como componentes desse diagrama de intensidades no qual nenhum dos elementos exigia verificação.

Todo esse aparato foi capaz de promover um diálogo improvável, que de fato instaurou um tipo de aproximação pela partilha daquela vivência. Se estivéssemos nos lugares de fala previsíveis, seguindo marcações já conhecidas como entrevistadores, observadores técnicos, tal qual na etnografia em seu registro stricto, ou na sala de aula convencional da Universidade, estaríamos pensando de outro lugar. Nessa interação, avizinhar-se pressupôs uma horizontalidade que reafirma o que Frei Betto reivindicou: a cabeça pensa melhor de onde os pés pisam.

No teatro da Cia. Pessoal do Faroeste, esses encontros faziam aflorar ditos e não ditos de um espaço ressonante da condição humana. Experimentávamos naquele início de parceria nem tanto uma incursão pelo território e pela situação das ruas, mas uma abertura para esses tipos de evento numa atmosfera liberada do desejo de conservar qualquer traço de distinção. Não que elas não existissem, mas o acolhimento mútuo confirmou-se como a possibilidade mais honesta de encontro - palavra tão marcante em cada fala dos professores e alunos - "nosso próximo encontro".

Quando a palavra “aula" cedeu lugar à palavra “encontro", as relações de poder ficaram menos relevantes e, também, cederam às relações de parceria no melhor dos sentidos: companhia como ato ou efeito de deslocar-se juntamente com o outro, ou ainda, como associação de pessoas, grupo organizado reunido em torno de um fim comum. Território de coexistência que define um tipo de teatro que preza por esse estatuto de companhia e, que nesse caso, pôde ser mimetizado de forma pedagógica por nós todos como espaço de criação e troca que é refratário à hierarquia e produz a multiplicidade. 
Vale lembrar a escrita de Viveiros de Castro, quando o antropólogo brasileiro abre o capítulo intitulado Uma antissociologia das multiplicidades pautado por uma crítica à psicanálise, feita por Deleuze e Guatarri, que refutam a concepção do desejo como falta, em $O$ Anti-Édipo (1972). A dupla propôs substituir essa noção por uma teoria das máquinas desejantes enquanto pura positividade produtiva que deve ser codifica pelo socius, a máquina de produção social. Viveiros discorre e contextualiza a formulação dos dois autores, que ele nomeia como "o autor dual", para trazer à tona a "sequência tradicional selvageria-barbáriecivilização na função de moldura expositiva, como as abundantes referências etnográficas são tratadas de um modo que se poderia chamar de "comparação aleatória" ${ }^{80} \mathrm{O}$ que chama a atenção do antropólogo é que essa aleatoriedade tem menos a ver com controles coletivizantes e mais com o uso de controles diferenciantes, como "prodigioso esforço para pensar diferentemente" (Donzelot 1977:28). Essa seria a chave que leva Viveiros de Castro a cunhar o termo "antissociologia" para pensar a diferença na horizontalidade.

As multiplicidades são assim sistemas cuja complexidade é "lateral", refratária à hierarquia ou a qualquer outra forma de unificação transcendente - uma complexidade de aliança antes que de descendência, para anteciparmos o argumento principal deste ensaio. Formando-se quando e onde linhas intensivas abertas (linhas de força, não linhas de contorno - D. \& G. 1980: 621) conectam elementos heterogêneos, os rizomas projetam uma ontologia fractal que ignora a distinção entre "parte" e "todo". Uma concepção de complexidade barroca antes que romântica, como Kwa (2002) persuasivamente argumentou. Com efeito, a multiplicidade é o quase-objeto que vem substituir tanto as totalidades orgânicas do Romantismo como as associações atômicas das Luzes, alternativa que parecia esgotar as possibilidades à disposição dos antropólogos; com isso, ela convida a uma interpretação completamente diferente dos megaconceitos emblemáticos da disciplina, Cultura ou Sociedade, a ponto de torná-los "teoricamente obsoletos" (Strathern et al. [1989]1996). ${ }^{81}$

A complexidade de aliança que permitiu " $R$ " fazer da raiz uma metalinguagem performática, do seu corpo um diagrama de intensidade, da raiz um rizoma que constituiu "uma

\footnotetext{
${ }^{80}$ VIVEIROS DE CASTRO, Eduardo. Metafisicas canibais. São Paulo: Cosac Naify/N-1 edições, 2015. p. 113.

${ }^{81}$ Idem, ibid. p. 118-119.
} 
complexidade de aliança" naquele momento no qual foi possível estar ali; e esse estar que parece pouco e que parece muito, quando o heterogêneo se justapõe e cria um território improvável que terá o tempo de duração e o tempo de marcação da memória sincronizados, para que a raiz produza ramificações insuspeitas, de acordo com "as predisposições culturais do observador" no ponto, na reta, no corte, no que se sustentará sem continuidade. $\mathrm{Na}$ multiplicidade de campos, o nosso Campus reinventado.

Se o conceito de multiplicidade ganha seu desdobramento como território de coexistência na Luz é porque essa lateralidade que conecta elementos heterogêneos, totalidades ao lado, descobre, no avizinhar-se pela (des)semelhança, a sua floresta urbana.

Viveiros de Castro, à medida que explora os platôs de multiplicidade, encontra no comentador do pensamento deleuziano, François Zourabichvili, um aliado que chama a atenção para o entendimento que o pluralismo deleuziano supõe como um "primado da relação".

Mas não se trata de "qualquer" relação. A multiplicidade é um sistema formado por uma modalidade de síntese relacional diferente de uma conexão ou conjunção de termos. Trata-se da operação que Deleuze chama de síntese disjuntiva ou disfunção inclusiva, modo relacional que não tem a semelhança ou a identidade, como causa (formal ou final), mas a divergência ou a distância; um outro nome deste modo relacional é "devir". A síntese disjuntiva ou devir é "operador principal da filosofia de Deleuze" (Zourabichvili 2003:81), pois é o movimento da diferença como tal - o movimento centrífugo pelo qual a diferença escapa ao atrator circular da contradição dialética. Diferença positiva antes que opositiva, indiscernibilidade de heterogêneos antes que conciliação e contrários, a síntese disjuntiva faz da disjunção a "natureza mesma da relação" (id. (1994) 2004:99), e da relação um movimento de "implicação recíproca assimétrica" (id. 2003:79) entre os termos ou perspectivas ligados pela síntese, a qual não se resolve nem em equivalência nem em uma identidade superior. ${ }^{82}$

Pela via da implicação recíproca assimétrica, proponho um breve retorno ao pedaço do quarteirão da rua dos Gusmões, no qual funcionava uma cooperativa de reciclagem. $\mathrm{O}$ que não era aproveitado, a sobra da sobra, era abandonado na esquina do Teatro de Contêiner na

${ }^{82}$ VIVEIROS DE CASTRO, Eduardo, op. cit. p. 119-120. 
altura do Bar do Clóvis, depois colocaram uma cesta de lixo capaz de receber o que um transeunte de passagem dispensa, como um bilhete amassado, uma guimba de cigarro, mas nunca o que abarcaria as sobras da triagem dos reciclados. Foi necessário mais de uma investida da Cia. Mungunzá no atendimento da companhia de limpeza urbana para fazer entender a necessidade de um recipiente compatível com o volume de descarte. E feita a substituição, mesmo assim, não deu conta do propósito, a sobra continuou sobrando.

Nesse mesmo lugar, próximo à cerca do Teatro de Contêiner, que funcionava como morada provisória das pessoas em situação de rua, permanecia o lixo desqualificado para reaproveitamento, misturado aos que dormiam por ali. Nesse panorama da calçada, a dinâmica da acumulação de gente e lixo criava uma dispersão capaz de, pela ausência de qualquer tipo de critério, banalizar a presença/ausência de gente e lixo. Tudo era sobra. Tudo era mais do mesmo, numa insistência em não viabilizar nenhuma proposta de mudança em macroescala.

"M", um dos integrantes da Cia. Mungunzá, falou-me que era surpreendente a rotatividade de quem ocupava a calçada. Pessoas que se instalavam por ali e de repente desapareciam, não voltavam mais. Ele constatava que a realidade impunha uma ausência de respostas para tais sumiços e, certamente, uma impossibilidade de qualquer tipo de vínculo com a vizinhança da cerca. Essa reflexão somente era possível para quem estava do lado de dentro da área protegida do pátio do teatro. Mesmo que a conversa se desse num dia dedicado a "autoestima, autocuidado e redução de danos" como reforçava o texto da filipeta do evento chamado "Rua Ex'isto".

Quem idealizou o evento foi "L", colaborador da Cia. Mungunzá, importante elo com a população em situação de rua. Jovem, negro, muito articulado, realizava boa parte do trabalho operacional que garantia a manutenção do teatro. Sempre disposto a ampliar o espaço de acolhimento, promover uma agenda inclusiva eficiente e criativa. "Rua Ex'isto" expressou, com a beleza da sua composição, algumas traduções possíveis para vivermos a implicação recíproca assimétrica na multiplicidade deleuziana.

A justaposição de três termos em "Rua Ex'isto" sugere uma equivalência entre o substantivo feminino "rua", o prefixo "Ex" da preposição latina ex/e, que significa "movimento para fora, tirado de", seguido do pronome demonstrativo "isto", que indica algo (coisa) que se acha espacialmente mais perto de quem fala, ou, temporalmente como acontecimento recente, 
ou, ainda, que está sendo ou será em seguida dito ou referido por quem fala. "Rua Ex'isto" traduzido como Rua tirado disto; ou, ainda, Rua fora dela. Como se "L" estivesse operando essa síntese desde sempre posta em ação quando se fez a oportunidade de atuar na trupe teatral. Ele não cabia mais na rua e nem o outros, como sobra da sobra.

Feita a transposição para a sentença: "rua, existo", o vocativo a quem se endereça o sujeito oculto "eu" reivindica a existência mesmo que oculta, invisível, naquele dia. Como verbo "existir" podemos eleger o sentido de elevar-se acima de, aparecer, deixar-se ver, mostrar-se como elemento tensionador do sujeito da ação. Situação recorrente para aqueles participantes cujas existências tensionam a rua, a cidade e os superintegrados, pelo simples fato de existirem sem outra proposição.

A sentença conta ainda com a presença do sinal diacrítico apóstrofo ('), que serve para indicar a supressão de letras, sons. Esse vazio entre o movimento para fora de (Ex), que na frase aparece como "Ex'isto", paradoxalmente antecede algo que está mais perto (isto). O sinal forma uma lacuna, uma vacância a ser preenchida pela multiplicidade da Luz. E pela textura sonora chegamos em "Rua és isto?". Quem responde esta pergunta?

Mesmo esses homens e mulheres que adentraram o pátio do teatro e que participaram do evento para cortar o cabelo, para comer uma comida especialmente feita para eles, mesmo os que puderam experimentar um jogo de bola ou um slam, a poesia falada em alto e bom som, experimentaram algo muito passageiro e sem nenhum tipo de aderência. O movimento para fora prevalecia, impossibilitava algo que se inscrevesse numa solução dada por uma autoridade a toda e qualquer questão submetida à sua jurisdição, ou, ainda, a uma frase lapidar que encerrasse um pensamento de ordem geral e de valor moral. O movimento, a vida, escapava da sentença.

Havia uma cordialidade entre anfitriões e convidados a partir de gestos à procura de qualquer traço de semelhança ou identidade, mas, se apelássemos para a linguagem teatral, os papéis ainda estavam definidos mesmo com todo o esforço de evitar textos decorados. Entretanto, havia também uma marcação que fazia da tentativa de avizinhar-se uma brecha, uma disfunção inclusiva no que compreendemos no termo deleuziano como a distância imposta no modo relacional, no que podemos assumir como o devir Luz. 
Nessa multiplicidade que se deu à medida das variações que se relacionavam e da distância que ia se diferindo, e não, como alerta Viveiros de Castro, como relações que variam simplesmente, compreendemos vizinhança como essa síntese disjuntiva que opera avizinhandose na "relação que relaciona". Um modus operandi dessa convivência, dos de dentro com os de fora da cerca. Sempre lembrando Nancy, a partilha da partilha. O entre da sentença "Rua Ex'Isto" como um módulo de diálogo, um território recriado na tentativa de sermos solidários na coexistência das contradições.

Viveiros de Castro cita e nos conduz ao pensamento do antropólogo Roy Wagner, que aqui nos ajudar a entender a relação de produção recíproca:

(...) entre o momento da convenção e o da invenção da "dialética cultural" (Wagner:1975) 2010:97; o termo é amplamente retomado em Wagner 1986). Mas tal dialética, sobre ser explicitamente caracterizada como não hegeliana, traz logo à mente a pressuposição recíproca e a síntese disjuntiva: "Uma tensão ou alternância, ao modo de um diálogo, entre duas concepções ou pontos de vista simultaneamente contraditórios e solidários entre si” (Wagner (1975)2010:96). ${ }^{83}$

Todos quando se visitavam nas atividades de convivência, artistas, ativistas e moradores em situação de rua, obedeciam a um programa performático no qual o reinado da palavra perdia importância para o corpo. Marcados que eram pela condição imposta da situação geral de estar dentro ou fora do contrato social, sem impedir que tais contradições expressassem uma solidariedade possível. A (des)semelhança na vizinhança da Luz exigia essa disponibilidade para a "distância entre pontos de vista, ao mesmo tempo, indecomponível e desigual a si mesma, pois o trajeto não é o mesmo nos dois sentidos" (Zourabichvili 2003:79).

Uns ofereciam "um dia de beleza", outros ofereciam cabelos, rostos, mãos, para lembrar que coexistiam na velocidade dos desaparecimentos voláteis, ali, naquela trégua. Tudo parecia durar o tempo da maquiagem que fez "C." ficar tão bonita e jovem novamente como se fosse possível lhe devolver a idade biológica com o uso de um delineador. Esmaltadas as suas unhas,

${ }^{83}$ VIVEIROS DE CASTRO, Eduardo, op. cit. p. 129. 
que retomaram a tarefa de dobrar o cobertor largado na calçada, naquele momento, ela mesma, cabelos lavados, cortados e escovados.

Não se soube muito os efeitos desse banho de beleza. Eu disse a "C." que estava muito bela e perguntei se podia registrar sua imagem. Minha única intenção era a de fazer da foto no meu celular um espelho para que ela se visse. Diante da situação, experimentamos a cumplicidade do vazio que não nos permitiu nenhum outro comentário. Talvez um dos momentos de maior aproximação, rapidamente desfeita por ambos, com suas devidas estratégias. Ela seguiu atrás de um cigarro para fumar, eu me ocupei da tarefa de oficineiro com o objetivo de engajar algumas crianças na produção de desenhos e colagens. Seguimos cada um do seu jeito após essa percussão.

\title{
IV. PROXIMIDADE
}

\section{A UNIVERSIDADE À ESCUTA DA CIDADE}

\author{
"Vocês são da faculdade? Voltem pra faculdade pra estudar \\ Leonardo da Vinci, Shakespeare!" \\ "M.", usuária de crack
}

Naquela noite de abril, em nosso oitavo encontro, dávamos continuidade à segunda edição da disciplina que levou a pós-graduação em Humanidades, Direitos e Outras Legitimidades, do Diversitas, para o território da Luz.

“O Lugar da Redes: Preservadas, Descartadas, Compartilhadas e Expandidas”, fazia parte da grade ofertada para o primeiro semestre de 2018, com as presenças dos professores Luís Galeão, Sérgio Bairon e Zilda Iokoi, no formato padrão dos nossos cursos de Pós-graduação que sempre contam com a participação de três docentes, em sala de aula. No caso, um psicólogo social, um comunicólogo e uma historiadora, respectivamente. Parceiros que se engajaram desde o início, com o Coletivo Diversitas, como veremos logo adiante, na empreitada de promover o deslocamento do protegido ecossistema universitário do Campus 
Butantã para o centro velho da cidade, ou, como Zilda Iokoi sempre enfatizou nas falas iniciais: "uma fuga do brejo do Butantã".

A proposta daquela noite era relativamente simples perto de outras atividades que produzimos para as quatro disciplinas que criamos e ministramos na região, num período de dois anos. Pretendíamos dar uma volta no quarteirão a partir da rua do Triunfo, onde se situa a sede da Cia. do Pessoal do Faroeste, nosso local de aula. O roteiro incluía o Largo Gal. Osório, de onde avistávamos a Escola de Música do Estado de São Paulo (EMESP) Tom Jobim e, no outro lado da Rua Mauá, alargando o horizonte, víamos também o complexo que abarca a Sala São Paulo, a Secretaria de Cultura do Estado, a Estação Pinacoteca e o Memorial da Resistência. Seguíamos pelo largo rumo ao Teatro de Contêiner da Cia. Mungunzá, na Rua dos Gusmões, nesse pequeno trajeto circular que garantia o retorno à sede do Pessoal do Faroeste pela própria rua do Triunfo.

No cruzamento entre as ruas, admirávamos as ruínas de um prédio antigo de arquitetura eclética que ainda faz lembrar o período efervescente da indústria cinematográfica, nos anos 1960 e 1970, ali, na Boca do Lixo. A esquina contava ainda com um dos hotéis sociais, o Hotel Zezinho 2, naquela época um sobrevivente do desmonte da política de redução de danos do Programa De Braços Abertos (DBA).

Um percurso que, naquele momento, eu já conhecia bem por conta das inúmeras atividades com os parceiros da área. Situação muito diferente do relato que registrei no texto "A criação como trunfo" do blog A vizinhança, aqui reproduzido em: São Paulo diante dos meus olhos: a Luz, como flagrante da minha primeira incursão na região, em 2014. O mesmo texto apresenta um resumo histórico da Boca do Lixo e a efervescência cultural que a fez protagonizar como polo da indústria cinematográfica brasileira.

Naquele dia, nossa intenção era sair e circular no entorno do Teatro do Pessoal do Faroeste, que acolhia com a generosidade de sempre os primeiros encontros da temporada, marcados por uma intensidade surpreendente de fatos importantes na cena nacional, dentre eles, um que chocaria o país: o assassinato de Marielle Franco e de Anderson Silva, no Rio de Janeiro.

O grupo composto por uma média de sessenta frequentadores tinha ocupado duas das primeiras aulas apresentando suas histórias de vida, entre alunos regulares da Universidade, 
alunos especiais e ouvintes. Gente de todas as raças e com biografias marcadas pelo desafio de viver nas quebradas paulistanas, nordestinas, Brasil afora.

O objetivo daquela incursão pelo bairro era ganhar a rua para situar os alunos no pedaço. Essas caminhadas roteirizadas e/ou concebidas como derivas sempre renovaram o nosso olhar sobre a cidade, por mais que o lugar, naquela altura da nossa presença na Luz já fosse conhecido. A ideia era apenas apresentá-lo para a turma. Existia algo importante naquela repetição do percurso, feita na velocidade de um corpo molecular de sessenta bocas, sessenta narizes, sessenta corações, cento e vinte olhos, cento e vinte ouvidos e cento e vinte mãos. Imprimia-se outra velocidade que de saída já rompia com a memória sensório-motora individual e apressada. Ganhávamos uma velocidade de gestos lentos, passos lentíssimos, de tantas pernas e tantas antenas a perpassar por detalhes, emblemas e marcas da cidade.

Parte do grupo era composta por alguns profissionais de saúde e de assistência social do próprio território, ativistas e artistas que no front conheciam a cartografia e suas nuances, em contraponto à maioria formada por neófitos, mesmo os nascidos na cidade. Muitos pesquisadores das ciências sociais afeitos às pautas inclusivas também experimentavam o frisson de andar a pé em estado contemplativo na Luz, pela primeira vez, bem como algum dos professores do Programa.

Exercício que sempre exigia um ajuste no foco das lentes para decifrar a síntese que combinava contrastes marcantes da miséria e da presença de um aparato cultural dos mais sofisticados. De um lado, a ruína exposta e estigmatizante da Cracolândia; de outro, a melhor sala de concertos da cidade, museus com reservas técnicas e exposições importantes. Atravessamentos que tornavam qualquer percurso programado um desenho sem garantias, um trânsito pela diversidade exposta ao acaso nas incursões sobre aquela região, também, como disse antes, conhecida como quadrilátero do pecado.

E nesse jogo, a distância do percurso era pequena e enorme ao mesmo tempo, marcada pelos microeventos a chamar a atenção de subgrupos dentro do grupo como um todo. Seguíamos já nessa encruzilhada, na qual o retorno parecia suave e eloquente, incluindo aí um flagrante da polícia revistando um homem negro que, desembaraçado do sufoco, passou por mim com um sorriso largo e disse em tom confidencial: "vocês me livraram da pica do saci!", que soube mais tarde tratar-se de repressão policial. 
Diante do Hotel Zezinho 2, "D”, nosso aluno ouvinte, usuário de crack e residente do hotel, começava a nos explicar o funcionamento e as regras de convivência. Foi nesse momento, no qual ele falava da sua rotina com os outros moradores para a câmera de um dos nossos alunos, que, de repente, em paralelo, o evento se deu: uma mulher muito magra com piercing no rosto, cabelos claros cortados bem curtos, também usuária de crack e moradora em situação de rua, roubou a cena.

Ela gritou, vociferou, questionou, intimidou e paralisou, com seu texto improvisado, o grande corpo acéfalo que estancou diante da sua presença a reivindicar atenção e, ao mesmo tempo, a protestar contra aquela situação, excursão, reconhecimento de campo. Éramos nós os pesquisadores, os professores, diante do desfio: como acolher? Como escutá-la? O que se ouve? Que diálogo possível se estabelece?

Se até aquele instante a visita guiada seguia um roteiro predeterminado, a rua impôs naquele cruzamento uma linha de fuga produzida dessa surpresa. "M" trazia a voz amplificada dos invisibilizados no território, seu grito sustentava uma distância gigantesca de um modo de existir desconhecido por aquele conjunto de corpos. Era o desafio de viver o ato performativo, de viver espaços liminares.

Não coube palavras para nos proteger do embate, "M" nos devolvia para a "academia que estuda Leonardo da Vinci”, escancarava a distinção explícita utilizando o nosso próprio repertório, expondo a nossa branquitude de cor e/ou de classe espelhada na figura dela mesma: branca e esguia. Proximidade que colocava em xeque a semelhança entre elementos conformes, ou melhor, um curto-circuito como destaca o antropólogo John C. Dawsey ao pensar o conceito de communitas.

Nos momentos de suspensão das relações cotidianas é possível ter uma percepção mais funda dos laços que unem as pessoas. Despojadas dos sinais diacríticos que as diferenciam e as contrapõem no tecido social, e sob os efeitos de choque que acompanham o curto-circuito desses sinais numa situação de liminaridade, pessoas podem ver-se frente a frente. Sem mediações. Voltam a sentir-se como havendo sido feitas do mesmo barro do 
qual o universo social e simbólico, como se movido pela ação de alguma oleira oculta, recria-se. A essa experiência Turner dá o nome de communitas. ${ }^{84}$

Ali, "M", com seu berro, sacudiu o manto opressor que há décadas encobre a população em situação de rua; não que tudo fosse novidade, mas a invisibilidade carrega o ranço do racismo estrutural brasileiro. "M" poderia ser o reflexo do nosso próprio espelho, ali, turvado por sua boca que gritou como um arauto e explicitou o abismo aberto por esse grito. O que nos chamava atenção tinha a ver com uma transferência na qual reconhecíamos nela, branca e esguia, uma projeção macabra de um dos nossos. Essa diferença não tinha nada de sutil, ao contrário, devolvia como um bumerangue o preconceito racial que na maioria das vezes está dissolvido por uma camada muito artificial de superação. Aquele instante expunha essa obscenidade.

Não, não seria possível caminhar pela Boca do Lixo sem se deparar com uma inesperada relação de residuais históricos passíveis de uma articulação com o presente, rearranjando o que Turner define como uma montagem. No caso, pego emprestado do cinema outro sentido possível para montagem como uma escolha arbitrária das sequências que sustentam uma ação e compõem uma cena. E ainda, penso em Turner como nosso roteirista da Boca para compreendermos uma rubrica que ele registrou, nos seus estudos sobre a antropologia da experiência: "nos dramas sociais o riso que faz estremecer as duras superfícies da vida social".

"M" gritou e fez a ironia ecoar nos ouvidos como um convite real para aquele corpo coletivo absorver o impacto. Ela expôs ao fora um dentro, nas palavras que se formam na “articulação da boca", não como meio de comunicação, mas incluindo o silêncio e a exposição,

\footnotetext{
84 John C. Dawsey no artigo Victor Turner $e$ antropologia da experiência http://www.revistas.usp.br/cadernosdecampo/article/view/50264, acesso em 22 Dez. 2020, nos ajuda a compreender o conceito de Communitas: Turner encontra nas discussões de Durkheim sobre "efervescência social" um exemplo de liminaridade e communitas. Cf DURKHEIM, Émile. As formas Elementares da Vida Religiosa. São Paulo. Edições Paulinas, 1989 (1912), p. 456. Communitas, termo inspirado pelas reflexões de Martin Buber; não deve ser confundido com qualquer princípio de organização social em comunidade, ou com formas de solidariedade descritas por Durkheim. Trata-se de uma experiência que irrompe de modo espontâneo a partir de momentos de interrupção das formas de organização social. Cf. Liminality and Communitas. In: TURNER, Victor, The Ritual Process: Structure and Anti-Structure. Ithaca (NY): Cornell University Press, 1969. p. 126-127.
} 
como a comunicação em si, segundo Nancy. ${ }^{85} \mathrm{O}$ que se experimentou a partir daquele momento foi o silêncio que se impôs num presente prolongado, frente a frente. Refletir sobre essa impotência paradoxalmente nada tem a ver com algum tipo de paralisia mas com um certo estilhaçamento.

Algo que me remete a uma situação que vivi com o amigo, ator da Cia. Mungunzá, Lucas Beda, um tempo antes, precisamente no calor paralisante de dezembro de 2016. Uma apatia cúmplice que poderia estar no mesmo roteiro da Boca, como primeira cena que desencadearia no plano sequência que nos trouxe "M" e que entregaria um outro momento importante como prenúncio desse limiar.

O quarteirão do Teatro de Contêiner estava muito vazio, realçava aquela vizinhança como algo totalmente apartado da cidade. De algum modo, o Natal não estava presente naquele pedaço apesar da época do ano. Restava-nos a solidariedade diante do desamparo e um sentimento de tempos difíceis na Luz; era a troca de poder na prefeitura e o efetivo começo da gestão Doria. Fomos buscar algum alento no Bar do Clóvis, quando tive a ideia de ler para Lucas, na tela do meu celular, Clarice Lispector:

Pois existe a trajetória, e a trajetória não é apenas um modo de ir. A trajetória somos nós mesmos. Em matéria de viver, nunca se pode chegar antes. A viacrucis não é um descaminho, é a passagem única, não se chega senão através dela e com ela. A insistência é o nosso esforço, a desistência é o prêmio. ${ }^{86}$

Ao terminar essa leitura, Lucas estava emocionado e não me ocorreu outra coisa a não ser pousar o copo de cerveja na mesa para abraçá-lo, mas errei a mira e soltei o copo no ar, que se espatifou no chão. Foi tudo muito rápido e, quando percebi, a garçonete chegou prontamente para me dizer com muita tranquilidade: "nenhum problema. O problema é quando cai e não quebra". Compreendi que inaugurávamos outra fase da nossa amizade/vizinhança na Luz: a do tempo estilhaçado.

"Seguimos, mas com os cacos no bolso. Outros tempos". Essa frase encerrou um texto do blog $A$ vizinhança intitulado $A$ dimensão do afeto, publicado em junho de 2017. E não se

\footnotetext{
${ }^{85}$ NANCY, Jean-Luc. A comunidade inoperada. Rio de Janeiro: 7Letras, 2016. p. 62.

${ }^{86}$ LISPECTOR, Clarice. A paixão segundo G.H. Rio de Janeiro: Rocco. 2009, p. 133.
} 
tratava de conjecturas, mas de uma constatação de que a vivência da rotina na calçada da Gusmões devolvia subrepticiamente um descolamento do que se dava naquela microrrealidade: a truculência policial que seria recorrente, a partir da gestão Doria, com tentativas frustradas e altamente violentas de alterar a paisagem, como quem apaga um erro na letra cursiva e crê num esforço higienista como saída para a região da Luz se reinscrever, sem rasuras, na narrativa da cidade. E quem sabe, entrar no calendário natalino das merecidas comemorações.

Ao contrário da calmaria daquele dezembro quente de 2016, diante dos estilhaços que reconfigurariam a forma de apreensão da realidade, não mais coesa e moldada numa esperança de avanços nas políticas de inclusão social, o que não compreendíamos, mas intuíamos, foi estratégico para quase dois anos depois, em 2018, escutar "M" na perspectiva Benjaminiana de "um tempo saturado de agoras". E na dimensão dessa tessitura, estava lá, na Boca do Lixo, a festa da rua, a miséria da rua, a rua nua. Nessa encruzilhada marcada pelo entrecruzamento desses objetos cortantes feitos de agoras, cada um experimentava do seu jeito a vida na cidade, compreendendo como constituição dessa vitalidade, o que Nancy percebeu como a “impregnação de uma identidade numa pluralidade onde cada membro, desse modo, se identifica tão somente pela mediação suplementar de sua identificação com o corpo vivo da comunidade". ${ }^{87}$ Cabem cinco registros da escuta do que "M" bradou, feitos por alunos da disciplina que participavam da caminhada. Relatos das superfícies estilhaçadas pela voz de "M":

Bel Santos Mayer, 51 anos, educadora social, aluna regular na disciplina:

Nestas divagações me distanciei do grupo. Caminhando mais atrás, segui olhando a arquitetura dos prédios; alguns em ruínas. Fiquei pensando na substituição das estruturas coloniais excludentes por novos modelos igualmente excludentes. Dias depois, nos depararíamos com "novas velhas" notícias de expulsão "de indesejáveis" das áreas centrais. Pensava nos muitos apagamentos da história, nas falsas promessas de inclusão social e cultural, nas omeletes feitas sem quebrarem os ovos... viajava... e aterrissei na voz escancarada de uma mulher, diante da filmadora de um de nós. Com cabelos bem cortados, piercings, boa oratória ancorada em palavras bem

\footnotetext{
${ }^{87}$ NANCY, Jean-Luc, op. cit. p. 37.
} 
pronunciadas, "M" (fui saber o nome depois, e arrisco grafá-lo com "ll") nos oferecia um cardápio temático para discussão: "Geopolitica mundial? Crise política do Brasil? Golpe contra a Dilma? Shakespeare? Romeu e Julieta? Vocês gostam de romance? Em qual idioma? Eu falo bem ao menos cinco. Podem escolher. Preferem arte? O impressionismo de Van Gogh?"

Livia Estrella, 30 anos, psicóloga, aluna ouvinte na disciplina:

"Quero ver você ir agora num pronto-socorro e ver se tem UM pediatra de plantão. Me fala!" - chegou rasgando o verbo, estremecendo o chão, emudecendo eu e Dentinho. Interromper uma fala eloquente de críticas legítimas? Não mesmo. Nos resignamos na humildade (e, confesso, até com um pouco de vergonha). Aliás, para se conquistar o respeito e reconhecimento das pessoas que vivem por ali, humildade sincera é a chave."

Luana Costa, 28 anos, jornalista, aluna especial na disciplina:

"Vocês ficam falando de Lula, de Dilma... Eu quero que vocês vão agora em um pronto-socorro e vejam se tem um pediatra lá. Só um pediatra. (...) O que vocês querem falar? De Da Vinci? É de Da Vinci que vocês querem falar? (...) Vamos falar do que realmente é importante" - "M" esbravejou contra nós enquanto caminhávamos pelas ruas da Luz. Ela esbravejou para mim e por mim aquilo que estava implodindo. É isso! Não quero falar, mas quero escutar.

Inês Mendonça, editora, 58 anos, aluna ouvinte na disciplina:

De noite, aula no Faroeste. No trajeto de volta do Mungunzá, uma moça, bem alterada, entrou entre a câmera e o " $D$ ", falando sem parar, perguntando sobre o que queríamos falar. Foi perturbador, mas me ajudou a relaxar. Não dá para saber o que fazer, estou perdida, estamos todos perdidos, o caso agora é relaxar e aprender o quanto der. Pedi para o Galeão um texto sobre psicologia comunitária, ele colocou no grupo, comecei a ler, a ideia é bem bonita. Fala sobre os sofrimentos psíquicos produzidos pela humilhação social. Nem toda neura é individual. Achei belíssima a ideia.

Jaderson Souza, 34 anos, aluno especial na disciplina:

Seguimos. Em frente a um hotel solidário e parceiro do \#Diversitas na incursão, um dos moradorxs parceiros explicou às pessoas sobre como era morar lá. No meio da escuríssima rua, uma moradora em situação de rua toma o meio da roda e desabafa. "Quem liga pra minha situação? Vocês querem 
falar de \#shakespeare? Querem falar de Van Gogh? Quantas línguas vocês falam? Eu falo cinco línguas!”

A opressão foi a partilha possível na polifonia de "M" fundida nas múltiplas vozes/escritas dos alunos: "estruturas coloniais excludentes", "estremecendo o chão, emudecendo eu", "não quero mais falar, mas quero escutar", "foi perturbador, mas me ajudou a relaxar", "no meio da escuríssima rua".

O convite com base na leitura desses registros passa pela combinação dessas escutas, compreendendo que articuladas e rearticuladas operam como expressão da comunicação tal como Nancy pensa comunicação: "o fato constitutivo de uma exposição da força que define a singularidade. No seu ser, como seu ser mesmo, a singularidade está exposta ao fora." 88

Pensar a vizinhança como essa singularidade que está exposta ao fora é pensar vizinhança como uma aproximação que demanda a presença na cidade. E o que comunica essa ação? À medida que escapávamos dos círculos de segurança, no nosso caso, o do Campus da Universidade, como um dos possíveis ambientes que Paulo Freire alertou como sendo os que aprisionam a realidade, pretendíamos conhecê-la melhor (a realidade) para melhor poder transformá-la.

O nosso desejo de agir começou a ganhar força, em 2016, com o incômodo de pensar temas urgentes sem conseguir lidar, em tempo real, com o conjunto de acontecimentos, sobretudo no período pós-impeachment da presidenta Dilma Roussef, em 31 de agosto daquele ano. Constatamos que um núcleo de apoio à pesquisa cujo campo se delineia pelo estudo de diversidade, intolerâncias e conflitos demandava um novo ato pedagógico: a mobilização para estar cada vez mais numa região da cidade que concentrasse uma ampla gama de situações concretas, reais, em diálogo direto com o conjunto de pesquisas e perfil dos pesquisadores do Diversitas. Assim, chegamos ao Teatro da Cia. Pessoal do Faroeste, na Luz.

A princípio, chegamos como Coletivo Diversitas, um arranjo composto por um grupo de professores, alunos e simpatizantes que passou a se reunir, numa agenda irregular, no Teatro

\footnotetext{
${ }^{88}$ NANCY, Jean-Luc, op. cit. p. 61.
} 
da Cia. Pessoal do Faroeste, com o objetivo de articular uma rede ativista. A iniciativa contemplava o desejo de se posicionar primeiramente frente à truculência da Polícia Militar do Estado de São Paulo nas manifestações que ocorriam, naquele 2016, na Av. Paulista. A criação do Coletivo contou com a presenças dos professores Zilda Iokoi, Luís Galeão, Renato Queiroz, Antônio Almeida, Maurício Cardoso e Paulo Endo. O primeiro esforço deu conta da criação e lançamento de um manifesto:

\section{MANIFESTO DE LANÇAMENTO DO COLETIVO DIVERSITAS - USP}

Os Pesquisadores do Diversitas, Núcleo de Pesquisas e Pós Graduação da Universidade de São Paulo, reunidos em plenária no dia 8/7/2016, criaram o COLETIVO DIVERSITAS/USP, para, em conjunto com os grupos dos movimentos em defesa dos direitos sociais, políticos, da cultura e das liberdades, atuar com os demais setores sociais nas lutas pela Diversidade e Democracia Já!

Estamos vivendo um enorme retrocesso em relação às conquistas sociais obtidas com o advento da Constituição de 1988. Tal retrocesso, sem precedentes, ataca as liberdades consolidadas no uso plural das cidades. Consideramos urgente nos posicionar contra as velhas práticas de cerceamento, exclusão e domínio das forças de repressão, entulho da ditadura vigente entre 1964 e 1985.

Nada foi enterrado, uma vez que o autoritarismo, instalado em numerosas instituições, em especial no aparato repressivo, mas também nas escolas, no universo simbólico da burguesia e de setores das classes médias, sorrateiramente se consolida nas práticas do atual governo ilegítimo, desqualificando e jogando no lixo décadas de conquistas históricas que custaram muitas vidas.

Ampliaram-se os controles das informações com o monopólio de alguns grupos conhecidos no domínio de todos os meios de comunicação de massa, e aparatos de informação foram reativados para investigar e criminalizar "os mais radicais".

Assim, convidamos a todos os defensores da democracia, hoje flagrantemente em risco no país, para que possamos nos reunir em torno de ações comuns e participar da agenda e do curso das manifestações que prometem ser longas e duradouras.

Reconhecemos a urgência de organização de pessoas, grupos e instituições que, nesse momento, buscam articulações entre si para propor ações e aprofundar reflexões sobre o grave momento que atravessamos no país, a fim de construir estratégias de enfrentamento ao golpe ora em curso. A resposta a esse golpe é o aprofundamento da democracia e do direito à diferença.

Trata-se de um convite amplo e aberto a todas as pessoas que sentem a necessidade de se organizar em ações conjuntas e incisivas, buscando mobilizar e coletivizar os recursos existentes e as potencialidades que pudermos reunir.

A proposta será apresentada pela primeira vez na próxima quarta feira, no Teatro do Pessoal do Faroeste, com a pauta aberta, já que se trata de um coletivo, e com 
algumas propostas já advindas de alguns grupos e pessoas, e que poderão ser mais bem definidas por ocasião desse encontro.

Todas as pessoas, ativistas, estudantes, trabalhadores, intelectuais, cidadãos e cidadãs estão convidadas a se unir a essa iniciativa, de modo que possamos dar início a mais um dos muitos coletivos que hoje se propõem a enfrentar a avalanche de retrocessos já realizados e outros, apenas esboçados.

A articulação entre membros do parlamento, do executivo e do judiciário, apoiados pela mídia monopolista, opera de forma organizada para a preservação de assimetrias econômicas, sociais e políticas, e é fortemente protegida pelo braço armado das polícias militar e civil, dentro e fora das delegacias.

É preciso responder à altura.

Aguardamos, no próximo dia 14 de setembro, a presença de todas as pessoas que desejam participar da nossa iniciativa.

Faça parte do Coletivo Diversitas/USP

Data: $14 / 09 / 2016$

Horário: 19:30h

Local: Teatro do Pessoal do Faroeste

Rua do Triunfo, 305 - Luz

Se o medo estava relacionado à opressão, ao desmonte das políticas públicas, à violência policial, à reação quando se ocupavam as ruas para exercer o direito de se manifestar, percebíamos mais de perto, na própria pele, um sentimento há muito experimentado pelos que eram recorrentemente discriminados por questões de raça, gênero e vulnerabilidade econômica.

O Coletivo Diversitas traduzia nesse Manifesto o início da jornada que que não encontrava outra opção a não ser a de fazer do agir a melhor das escolhas. Naquele momento, o convite feito pelo manifesto: "reunir em torno de ações comuns" ainda era bastante desconectado da realidade que experimentaríamos com o passar do tempo e com situações importantes como a escuta de "M" no território.

Num estado de alerta constante sobre a necessidade de ampliar a conexão, evocando a síntese temporal dos vários "agoras", sempre fiz questão de reverenciar a ancestralidade do lugar, ao abrirmos os encontros noturnos na Luz. Mesmo que o elo fosse roto, evidenciando a recorrente falta de fixação da população pobre na zona central e, por consequência, o desprezo pela sua história, procurava evocar a memória da vida dos que por ali ocuparam o pedaço. Agradecíamos e pedíamos licença para os negros, nordestinos, prostitutas, imigrantes que chegaram pelas vias férreas ou pela antiga rodoviária e pensaram na cidade como uma 
alternativa para uma vida melhor. Era um começo possível e tornou-se sempre o começo necessário.

\section{DO QUE VOCÊ TEM MEDO?}

A matéria constituidora das nossas disciplinas, ou melhor, de uma disciplina ativista, termo cunhado por Sérgio Bairon, somente se expressa pela via da produção partilhada do conhecimento, resultante da expressão viva da comunidade e que nos libera para o fazer, para o refletir, para o diálogo e para o silêncio da escuta e da escrita. A pergunta "Do que você tem medo?" feita por Zilda Iokoi foi um disparador arguto no início das apresentações individuais do grupo que iria ver-se frente a frente com "M" e nos levaria a outra questão: quem são os oprimidos? Como nos percebemos diante do desafio radical proposto por Paulo Freire de transformação objetiva da força opressora ${ }^{89}$

Proponho retornarmos ao início daquele semestre marcante, melhor localizado nas três primeiras aulas daquele outono de 2018, no qual o Coletivo Diversitas já tinha se diluído na presença oficial do Diversitas USP e experimentávamos outro grau de articulação com a Luz. Primeiramente dividíamos a surpresa da intensidade que se instaurou nessa fase de apresentação geral. Naquela edição, a nossa proposta que investia mais fortemente na itinerância como dinâmica da disciplina no território, contava com agenda programada na Casa Florescer, na Cia. Mungunzá e no endereço oficial do curso, na Cia. Pessoal do Faroeste; o que nos obrigaria a circular e interagir com mais interlocutores no território, concretamente os parceiros que elegemos para estabelecer o vínculo com a Universidade.

Muitos alunos tinham a expectativa que nosso trabalho mergulhasse diretamente na cena do consumo de crack, na tensão policial da Cracolândia, mas sabíamos de antemão que não permaneceríamos no ambiente o tempo suficiente para avançar nesse front e que um trabalho mais efetivo apontava os mediadores culturais e sociais como representantes legítimos de uma parcela dos agentes locais - a que escolhemos para atuar em rede. Nos dois encontros

${ }^{89}$ FREIRE, Paulo. Pedagogia do oprimido. Rio de Janeiro/São Paulo: Paz e Terra, 2019. p. 50. 
seguintes, ficamos por conta da apresentação da história de vida de cada um dos alunos participantes, eram em média sessenta, e da resposta a uma provocação feita pela professora Zilda Iokoi: "Do que você tem medo?".

Naquela caixa preta do teatro, com a plateia lotada em formato de arena, Zilda Iokoi no centro, em destaque, encarnava, como professora decana do Diversitas, um retrato digno do que Derrida associa com a figura do professor: "uma profissão de fé, um compromisso, uma promessa, uma responsabilidade assumida valem-se não de discursos de saber, mas de discursos performativos que produzem o acontecimento de que falam." ${ }^{90} \mathrm{E}$ a provocação de Zilda despertou a solidariedade do grupo pelo desemparo geral da própria exposição, num momento tão difícil do país que acumulava as perdas dos direitos civis e da agenda social. Esse ajuste necessário se deu para que não olhássemos a população em situação de rua, os usuários de crack, sem antes lembrar de que a opressão estava em nós mesmos, no arco amplificado dos pactos institucionais contemporâneos que tensionado pela perda de direitos e pela pressão neoliberal encontrava no próprio modus operandi da vida acadêmica brasileira uma síntese do colapso nacional. A seguir a resposta à pergunta de Zilda "Do que você tem medo?" no eco de seis respostas:

Meu nome é Edilarmar, mas todos me conhecem como Dila. Estou num momento agora muito difícil ... a morte da Marielle me atravessou de uma maneira muito forte. Num momento em que esse encontro estava me enchendo de tanta esperança, tinha saído daqui tão feliz. Essa morte dela me atingiu no ponto do desejo da esperança, sabe? Saí daqui tão mobilizada e aquilo veio como um choque de realidade. Tenho chorado todos os dias por causa disso e acho que isso define o meu medo que as coisas matem as esperanças da gente. Apesar da mobilização. Sou professora na FAAP faz muito tempo. Eu transito entre mundos muitos distintos porque a FAAP todo mundo deve saber é uma faculdade muito rica.

Me define também que eu sou filha de um homem eletricista. Pai e mãe que são trabalhadores desde infância. (...)

Me chamo Bel, Isabel Aparecida dos Santos, minha mãe queria pagar um monte de promessas... Ela deixou duas filhas na Bahia quando meu pai

${ }^{90}$ DERRIDA, Jacques. A universidade sem condição.. São Paulo: Estação Liberdade, 2003. p. 26. 
migrou, fugiu de uma ameaça de um patrão. Eu casei com um alemão. Passei a chamar dos Santos Mayer. E quando saí daqui na semana passada eu sentei para escrever sobre o medo. Eu resolvi começar pelo medo e escrevi que o meu medo era que o genocídio da juventude negra passasse a chegar nos negros universitários. Eu venho da zona leste de São Paulo e passei a minha vida pulando corpos de meninos para estudar em Santo André. Porque meus pais achavam que a escola em Santo André era melhor e a gente tinha que passar por uma ponte onde se descartavam os corpos. Tanto a polícia, como os traficantes e a gente, criança, pulava um corpo de alguém que você não conhecia. E aí eu entrei com o padre Júlio Lancelotti na luta pela causa da criança e do adolescente, nós ajudamos a criar o centro de defesa de direitos humanos e defesa da criança e adolescentes - CEDECA Interlagos. CEDECA Monica Pain Trevisan e aí os mortos deixam de ser anônimos. São meninos que você viu crescer, são irmãos dos seus amigos, da vizinha. E a gente entendia que aquelas mortes estavam ligadas aos meninos que não estudaram, os meninos que estão no tráfico. A gente começa a ver nas redes sociais, cada vez mais, meninos e meninas que têm lutado pra estudar, fazendo denúncias. Como a Marielle, no Rio, como a Áurea, em Belo Horizonte. E aí eu escrevi: esse é o meu medo (...)

Tony, cursando a disciplina pela segunda vez. Sou artista multimídia, venho da zona leste de São Paulo, São Mateus, sou de um coletivo de arte e tecnologia chamado Coletivo Coletores. O primeiro e talvez o único a atuar com arte e tecnologia na periferia, trabalhando não só a parte de conhecimento, transmissão de conhecimento. Faço mestrado na ECA, Ciência da Informação, trabalho na intersecção entre formação e cultura. Meu interesse na disciplina a priori é justamente pensar um espaço de crítica à Academia. Que muitas vezes ela se "cerca" em si mesma, na relação nós e eles. É uma das coisas que mais discutimos: "temos que ir até eles", eu acho que não. Eu me sinto nesse entre lugar, sou preto periférico tatuado, fazendo mestrado na USP, 33 anos. De alguma maneira superei muitas estatísticas e a ideia de estar aqui esse ano. (...) Pra mim um dos maiores medos é ter um karoshi, termo japonês que é a morte por excesso de trabalho (...)

Dentinho. Boa noite a todos. Sejam bem-vindos. Eu sou o Clayton Ferreira, mais conhecido nas ruas de SP como Dentinho, filho de dois nordestinos. Mas eu me considero um paulestino. Sou formado na superfície das ruas. Meu doutorado é Cracolândia. Sou benificiário do DBA, a cultura me trouxe aqui. Hoje, eu sou artista plástico, escritor, quadrinista. Mais um sobrevivente das ruas de São Paulo. Tenho muito a compartilhar e muito a aprender. Acredito que muito a aprender em partes culturais, políticas e também vim falar pra 
vocês um pouco da nossa diferença. O medo? Não tenho! Qual seria meu medo, hoje? Não tenho medo. Agora, gostaria que vocês pensassem no medo das pessoas que são o meu povo, a minha família, a Cracolândia. A opressão, a ridicularização, a indiferença. A parte do sanitário, né... tem muitos que passam... Essas mentes corrompidas que nos colocam totalmente criminosa. Marginalizando pessoais normais, usuários no dia a dia. Adictos como eu. Hoje, eu tenho graças a Deus e participo de um programa chamado DBA - De Braços Abertos que por causa de muitos políticos dessa nova geração burocrata, como diziam... o fantástico mundo de Dória, está acabando $(\mathrm{O}$ DBA), onde pessoas que estão num segmento de criação que sou eu, um ser humano que tempos atrás vivia com um cachimbo traficando e roubando. Não é orgulho, nem vergonha. É construção. Se coloca, hoje, pra vocês e fala aqui: o que é medo? Meu medo é retroceder tudo isso aqui que eu consegui chegar, né? Que uma moradia que tenho ali, por mais que tenha problemas... mas é uma moradia. Nos vamos ser colocados na rua de novo. Ser mandado pro CTA. Onde nossa autonomia está sendo roubada, onde somos ridicularizados todos os dias com o chamado bolsa-noia que é um sustento no dia a dia (...) É um sonho, sim. Uma coisa que não chega ao povo das drogas, não que eu parei de usar. Hoje, uso de forma recreativa. Acho que tem prazeres na vida que a gente tem que apreciar. Ninguém é mais ou menos. A gente vive não no controle, mas no equilíbrio, isso eu aprendi nas ruas, tá? Falando de frente aqui pra vocês, não enxergo as luzes. Porque eu tenho uma deficiência muito grave de visão e porque essa visão aqui me foi tirada por uma operação policial. Uma bomba de gás lacrimogênio explodiu no meu rosto... todos aqui têm suas formações, todos aqui têm seus medos... mas a maior faculdade que existe é a faculdade das ruas, faculdade que muitos aqui têm medo de conhecer. Qual é o medo? Será que é o medo de entrar no meio do fluxo? Lá onde o pessoal tá lá sendo oprimido, onde o pessoal passa lá e vê na mídia nos pixel, nos 1040 pixels, numa tela grande... será que é difícil... porque o que a gente pede pra vocês, não que somos coitados, é respeito. $\mathrm{O}$ que o usuário mais teme é a falta de respeito da comunidade, isso faz ele ser imprudente, faz ele ser rebelde. Eu era assim, era um cara que pedia cigarro pra você e você respondia ahh não tenho e eu sabia que você tinha... Hoje em dia, graças a Deus, eu com minhas pernas, minhas forças, minha coragem, eu consigo comprar um cigarro. Consigo ter minha dignidade, consigo ter meu momento... hoje, tô limpo, bem trajado, sou um cidadão, mas eu não deixei de ser um usuário de drogas, sou um usuário de crack. Não diferente de um engravatado aspirador. Por que nós somos tachados? Somos ridicularizados, sendo que o maior consumo de drogas é nas grandes raves, é nas grandes orgias das grandes capitais. Os maiores aspiradores são os caras que fazem o maior crescimento do índice de tráfico de drogas... traficantes. É o povo pobre que todo dia sofre. Por que? Porque não tem cultura, porque é um povo ignorante. Fantoche do sistema. E graças a Deus, com o apoio de muitos 
profissionais que aqui estão perdendo seus empregos, que não é justo, tá... que nos ajudam todos os dias. Atritos tem sim porque dificilmente para nós usuários compulsivos tá... porque eu falo: o crack é uma coisa muito difícil... a todo o minuto é uma guerra. Todo o minuto é uma guerra... só falar do crack me dá água na boca, tá? O que faz forte pra eu não tá lá? É uma aula dessas. Isso é redução de danos também... isso aqui tem que ser para várias pessoas... poder abrir espaço pra outras pessoas com faltas culturais porque $\mathrm{o}$ entretenimento, o teatro, a cultura... vamos puxar mais pessoas pra conhecer também... não sou aquele cara que está nas mídias sociais, mas que está na mídia urbana (...)

Pedra Homem, soteropolitana, nordestina. Que preta, em 2014, deu salto mortal de Salvador para São Paulo e veio parar na rede pública de ensino do Estado de São Paulo. E o grande desafio, também era o propósito desse salto mortal, era uma fome de existência absurda e essa fome de existência que esbarrou nessa muralha burocrática que é em particular a rede pública e estadual de SP. Não que lá em Salvador não seja, mas aqui é muito mais forte. Com esse desafio de existir nesse espaço, esses espaços onde os conceitos são... narrar a si mesmo (...) fragmentação entre artista e performer e a atuação como docente. E nessa muralha burocrática meu corpo foi convocado a existir e a arte a potencializar essa potência do escolar. Então, eu não tinha nenhuma pretensão de chegar à universidade. Eu queria fazer estudo de artes que comecei desde que cheguei, né... A minha base de formação artística é a literatura, né? Conjugada com performance e música. E aí esses não saberes e essa conexão com os desejos comuns começou a gerar aquilo que parece impossível dentro de um espaço dominado por um modelo enrijecido burocrático que é gerar narrativas. Narrativas diferenciadas daquelas que a gente escuta do espaço-escola. Então, hoje, eu partilho essas narrativas, desde o início do ano letivo de 2016, nas redes sociais e foi esse partilhar que me levou ao mestrado profissional em artes na Unesp, que estou fazendo a defesa agora em julho, de uma defesa chamada Pedra Homem, que é meu nome, o nome que me encontrou. Pedra Homem, professor, cabra fêmea, o diário escolar performativo. E com arte como resistência e (re)existência dentro do espaço. (Re)existência enquanto docente, enquanto artista. Recuperando esse espaço escola, esse corpo solitário/solidário que tem um compromisso de recuperar o centro de debates, espaço de experimentação e com espaço de auto- fabulação. Todo dia pra eu parir alguém que já nasceu, eu preciso me parir, eu preciso criar. E desse lugar eu não saio, ninguém me tira! E tendo essa questão de criar espaços de empatia. Esse sistema administra essa palavra que está sendo partilhada, aqui, o "medo". Esse sistema administra o medo. E o medo e o seu contrário é a esperança. Então sempre vão criar uma narrativa 
ameaçadora para poder vender uma esperança. Vender uma expectativa de um bem por vir. (...)

Olá, humanos. Eu sou Lívia Estrella. Integro a rede de atenção psicossocial da Luz enquanto técnica em uma das moradias provisórias daquele que foi o programa municipal de Redução de Danos "De Braços Abertos", hoje atual Redenção. Diria que estou no limbo dessa transição de programas com propósitos distintos. Do latim limbus, limbo significa margem, beira, borda, orla. A sensação é de estar arrastando-me dentro das águas turvas do manguezal da maior cena de uso de crack do país, percorrendo o lodo fétido desta cidade. Um solo que, apesar de poluído, sujo, é rico em nutrientes, justamente pela alta quantidade de matéria orgânica (de vida) em decomposição. Carangueja que sou, caminho bem por aqui... Do que eu tenho medo? Tenho medo de viver uma terceira guerra mundial. Tenho medo de que o medo produzido e propagandeado pelo Estado, veiculado pela TV, reproduzido pelos adultos, obscureça os sonhos e asas das crianças, e elas sigam esse sistema mórbido consumista-contumaz sem questionamento, reflexão, rebelião, revolução... sem afetação. Tenho medo de mais crimes ambientais como o do Rio Doce, Belo Monte (só para citar os mais recentes). Tenho medo que amigas e amigos sejam executados como Marielle, Anderson e mais outros tantos e tantas. Tenho medo de me acostumar com o Estado de Exceção, com a naturalização da violência estatal. Tenho medo de ver pessoas próximas entrando em colapso sem conseguir ajudar. Medo que o poder gerado pelo saber das letras torne complexo, racionalize e reduza os espíritos cerceando minhas relações com indiferença e arrogância (...)

Foi um ofertório de histórias brasileiras marcadas por um ritmo de biografias postas como num banquete de singularidades. Dessa forma, experimentava-se a constituição de um coletivo, "de um corpo vivo da comunidade."

Uma travessia: passamos seis, sete horas, em dois encontros inteiros, nos escutando. Havia uma surpresa geral, um improviso para a acomodação dessa demanda no roteiro que elaboramos e que, entre nós, como articuladores da disciplina, experimentávamos com certa dúvida, insegurança e perda de controle. Eu fiquei sempre incumbido de mediar os encontros, fazer os combinados gerais, controlar o tempo das falas, mas, como os professores, rendia-me ao experimentalismo. Na condição de doutorando do programa, colaborador direto dos

${ }^{91}$ NANCY, Jean-Luc, op. cit. p. 37. 
docentes na mediação com os parceiros da Luz e coautor das disciplinas, encontrava um companheirismo digno de registro.

Tanto Zilda, Sérgio e Galeão, naquele momento, como adiante os demais professores

que participaram das edições seguintes, sempre dialogaram livremente sem nenhum questionamento dos papéis que costumam marcar a hierarquia acadêmica na sala de aula.

\section{DO QUE A UNIVERSIDADE TEM MEDO?}

A tríade (des)semelhança, proximidade e amizade recriou, como acorde entre esses três sons, relações abstratas de vizinhança também na universidade, tal qual no espaço citadino. $\mathrm{O}$ que se compôs e reverberou a partir das múltiplas composições tem a ver com a disponibilidade dos sujeitos para o avizinhar-se na própria academia. Trata-se dos afetos como linguagem que se comunicam à medida que a partilha exige presença, e estar presente abre todas as possibilidades de criar outras propostas, outras pesquisas, no nosso caso as disciplinas ativistas na Luz. Esse avizinhar-se sustentou a experimentação desse conjunto de possibilidades, que caracterizaram parcerias com maior ou menor grau de (des)semelhança entre os integrantes, maior ou menor proximidade e amizade. A abertura para a troca produziu, e produz, possibilidades de outros arranjos até entre os que, primeiramente, apenas criticaram a iniciativa.

Pensar o Campus principal da Universidade de São Paulo, situado no Butantã, pela multiplicidade de campos, como vimos antes: como campo de pesquisa, como campo grande da lavoura colonial e como devir campo, é pensar desafios consistentes. O Campus do Butantã possui uma aridez diferente porque é resultante de um esforço consciente e compactuado de segregação. Lugar idealizado para reproduzir um projeto de elite pouco afeito a promover alguma linha de fuga do convencional e, historicamente, marcado pela retirada da atividade acadêmica da vida multicultural do centro da cidade, no período da ditadura militar.

O que interessa é chamar a atenção para como o conjunto do Campus destaca o sistema vertebrado, lembrando Appadurai, ao possuir essa estrutura grandiloquente na topografia que 
dispersou a interatividade das pessoas, num espraiamento de prédios pouco propícios à convivência numa área verde incrivelmente bucólica. Sistema que preza pela manutenção de um outro tipo de assimetria relacionada ao poder que organiza as faculdades e determina um distanciamento entre docentes, discentes e o próprio quadro técnico administrativo, que é bastante apartado no convívio geral da comunidade universitária.

Desde os anos 1970, o deslocamento da USP para longe do centro da cidade de São Paulo teve como consequência a diminuição das chances de contato com pessoas detentoras de outros saberes, outras práticas, quase sempre descredenciadas por não terem uma produção referendada e, quando muito, reconhecidas para tornarem-se objeto de pesquisa sem voz ativa. Incluem-se nessa gama de enjeitados do saber formal, constituído como tal, os detentores de todo tipo de memória oral, como: os povos originários, os quilombolas, as religiões afrobrasileiras, a canção popular, a produção cultural das quebradas, a cultura queer, LGBTQI+ e todo o legado que não representa estudos avançados no sentido mais conservador da tradição canônica e da autoridade europeia.

Diante de tal composição, como fazer aflorar outras amálgamas? Criar micropolíticas no Campus? Avizinhar-se da diversidade? Promover uma abertura para inclusão, sem medo das minorias. Tê-las não apenas como audiência, mas também como protagonistas nas tomadas de decisão e no desenho de propostas?

Inúmeras vezes vivenciamos essa fissura entre os discursos articulados em prol da reparação social e a repetição de processos que sustentam o modelo hegemônico da Universidade de São Paulo, primeiramente por falta de representatividade das minorias nas funções de poder, segundo por pouca difusão de algumas conquistas nesse sentido. Para ficar apenas com um exemplo emblemático: das dez posições que compõem o organograma da reitoria, oito são ocupadas por homens brancos, somente uma posição está ocupada por uma mulher branca e outra vaga está vacante no momento dessa aferição, em agosto de 2020. Num país em que, segundos dados de IBGE, o último censo de 2010 confirma a maioria da população declarada negra, totalizando $50,7 \%$ entre pretos e pardos, temos um retrato institucional defasado num discurso politicamente correto, mas tímido diante do desafio de promover mudanças estruturais de fato. 
O desenho do Campus da USP e a arquitetura característica dos espaços de educação pública no Brasil sinalizam estruturas de poder que revelam marcas dos ciclos de êxito e abandono, de acordo com o momento político. O esforço de repensar a Universidade dentro do próprio ambiente de refúgio, com debates, simpósios, congressos, relembra a polêmica que impregnou a cena política nacional, desde o impeachment presidencial de 2016, a exigir uma autocrítica da esquerda sem a sinalização de um pacto em torno de uma abertura capaz de promover mudanças efetivas no sistema político como um todo.

No mesmo tom de discurso, quando pensamos de forma mais ampla a revisão do modelo da universidade pública, também impregnada de conservadorismo, intelectuais de direita e recrutas de extrema-direita, deparamo-nos com a polarização espelhada no país e o debate de ideias protagonizado por figuras abstratas: a máquina pública, o mercado, as agências de fomento à pesquisa. Sujeitos fictícios responsáveis por tudo e por nada, temidos pelos que acreditam na sustentação de uma neutralidade, em última instância, na manutenção da própria estabilidade no sentido mais amplo da existência, custe o que custar o controle da produção acadêmica.

Exige-se uma revisão dos modelos pelo lado que defende a universidade pública integral e reivindica as perdas acumuladas; no lado oposto, almeja-se a revisão reformista que defende mais verbas a partir de parceria público-privada. Ambas não se debruçam sobre o fundamento, a origem do sistema como um todo e uma possível recompactuação que deveria levar em conta o questionamento das bases que modelam a produção científica no país.

Por não mergulhar nesse enfrentamento, nós seguimos sem nos reinventarmos mesmo com a absorção de mudanças impactantes a partir do uso das plataformas digitais, da política de cotas e de intercâmbios que trariam possibilidades do ultrapassamento da ideia reguladora da educação, tal qual Nancy apresenta como sinônimo da fabricação da sociedade humana. A flagrante estagnação.

A inércia também explicita o rechaço de muitos integrantes da vida acadêmica no que se refere ao que qualquer mudança estrutural poderia acarretar, até porque estaria relacionada ao convite de Nancy para liberarmos o horizonte atrás de nós. Ou seja: "a consciência desse deslocamento é aquela de Rousseau: a sociedade identificada ou reconhecida como a perda ou como a degradação de uma intimidade comunitária (e comunicativa), que agora produz ao 
mesmo tempo, pela força, o solitário, mas pelo desejo e projeto, o cidadão de uma comunidade soberana livre". ${ }^{92}$

Como solitários, no contexto individualista neoliberal das agências de fomento, calibramos a nossa recorrente ambição pessoal, incapazes de compreender a dimensão da força dos atores no coletivo que buscam viver a educação plena a partir da ação e da exposição de si mesmo aos outros sem tréguas - situação que nos educa para reconstruímos ad infinitum o castelo de cartas da utopia da comunidade soberana livre. Ao contrário, no ambiente intelectual, nas salas de reunião da Universidade, é detectável o silêncio que explicita uma ausência de convicção ou, ainda, uma presença colérica e ressentida sobre o que estamos vivendo, sem a oferta de nada além da previsível constatação da perda do horizonte democrático. Passamos pelo desentendimento crônico do exercício fundamental da cidadania, e pela perspectiva camuflada de um "nós" de baixa intensidade contra um "eu" franco atirador.

Essas tensões recorrentes evocam um passado fantasmagórico no qual encontraríamos o que Nancy definiu como comunidades perdidas ou rompidas que projetavam uma relação de "ligações estreitas, harmoniosas e resistentes e, nas suas instituições, ritos e símbolos", ${ }^{93}$ mas que sobretudo lamentam a perda da representação de sua intimidade e autonomia imanentes. Esses protestos são toucas que vestem bebês sem cabeça, vestem com a falsa proteção de evocar o que nunca se viveu na Universidade. Lamentos que soam fantasiosos, localizados numa vocação iniciática que parece sempre muito melhor. $\mathrm{O}$ filósofo francês nos alerta para a suspeita da "consciência retrospectiva da perda da comunidade e de sua identidade ${ }^{94}$ e temos que lidar com essa suspeita em tempos estilhaçados.

As perdas são evidentes, sob a ótica do direito trabalhista e da monetização do ofício constata-se facilmente a vulnerabilidade do ganho, da composição salarial e, portanto, do poder aquisitivo. O camburão neoliberal que sequestra e tortura os ativistas, os professores universitários, os pesquisadores, os artistas, entre outros, não repete o mesmo modelo da violência da ditadura militar brasileira, nos anos 1970. Ele é guiado com a missão de chegar

\footnotetext{
92 NANCY, Jean-Luc. A comunidade inoperada. Rio de Janeiro: 7Letras, 2016. p. 36.

${ }^{93}$ Idem. p. 37.

${ }^{94}$ Ibidem. p. 37.
} 
nas instituições democráticas e, possivelmente com autonomia crítica, com o implacável sufocamento financeiro.

O efeito dessa sorrateira investida é a negação da importância da pesquisa com impacto no corte nas bolsas de estudos, na ausência de suporte financeiro para as agendas internacionais em congressos e palestras, na defasagem tecnológica e, também, na manutenção de um esvaziamento perverso do modelo administrativo com um organograma e fluxograma do quadro precarizado, defasado e ineficiente, em sua maioria.

Vale ficarmos alertas, também, para o uso manipulatório das reivindicações de tais perdas a serem restituídas e que, sob a condição da restauração integral das condições de produção, nos tornariam capazes de lutar por um bem maior, mesmo que isso custasse, como estratégia de vitória, a oferta viva da própria unidade no extremo do tudo ou nada. Será? Na primeira ventania, esses rompantes nos devolvem algo de funesto: encaminhamentos que não nos levam a nenhum outro caminho do que o dos dedos amortecidos. Como nos revela um sonho literário de Coetzee: "O rosto que vejo é vazio, sem feições; é o rosto de um embrião ou de uma baleia minúscula; não é um rosto, mas outra parte do corpo humano que se avoluma sob a pele; é branca; é a própria neve. Entre dedos amortecidos estendo uma moeda". ${ }^{95}$

\section{A CIDADE EDUCADORA}

O que é revolucionário, para termos sempre Paulo Freire entre nós, tem mais a ver com investir nessa economia libidinal e perseguir o que somos capazes de acolher na diferença do que projetamos. Aqui, recorro a ajuda de Nancy para pensarmos o que nos constitui como Universidade na cidade:

a comunidade não tece o elo de uma via superior, imortal ou transmortal entre sujeitos (do mesmo modo que ela não é tecida por ligações inferiores de uma consubstancialidade de sangue ou de uma associação de necessidades), mas

\footnotetext{
${ }^{95}$ COETZEE, J. M. À espera dos bárbaros. Tradução: José Rubens Siqueira. São Paulo: Companhia das Letras, 2006. p. 53.
} 
ela está constitutivamente, desde que se trate de uma "constituição", ordenada à morte daqueles que chamamos talvez erroneamente de seus "membros" (se é que não se trata, nela, de um organismo). ${ }^{96}$

Nada se compara a "pensar de onde os pés pisam", a frase de Frei Betto que sempre expressava a emoção e o tesão com o qual Luís Galeão pontuava a própria fala para o grupo, na Luz. Ouso complementar que se faz necessário pensar aonde os pés pisam sem esquecermos que será por um tempo breve, dada a nossa descontinuidade quando assimilamos a poderosa noção de finitude. Digo poderosa porque, ao mesmo tempo que ela relativiza os contextos e amplia em perspectiva o que se apresenta na síntese passado, presente, futuro, a compreensão de finitude nos traduz uma outra inserção na comunidade: a que escapa da imanência e toca a ancestralidade e o sonho do amanhã.

Nancy cita Bataille para cirurgicamente lidar com o dentro/fora tão presente na filosofia contemporânea; ambos, ao refletirem sobre a experiência interior, enfatizam que ela não tem nada de interior, nem de subjetiva e que, portanto, "é indissociável da experiência dessa relação com o fora incomensurável. A relação, somente a comunidade provê seu espaço e ritmo. ${ }^{97}$ Esse conjunto de fatores retira a poeira depositada pela apatia e/ou apego às condições idealizadas para agir, se conseguirmos, é claro, levar a sério e paradoxalmente brincar com a desconstrução das próprias verdades no balanço do dentro/fora que nos insere como sujeitos relacionais na comunidade.

Milton Santos, ao reinterpretar Heidegger, corrobora essa experiência da consciência desse alinhamento ao refletir que "o onde determina o como do ser, porque ser significa presença." ${ }^{98}$ Segundo o geógrafo, a ação é ação em um espaço e é o espaço que dá forma a ação. Portanto, o espaço é relacional e podemos correlacionar com o que Nancy chamou de a experiência moderna de comunidade: "nem obra a ser produzida, nem comunhão perdida, mas o espaço mesmo, o espaçamento da experiência do fora, do fora de si" ${ }^{99} \mathrm{O}$ território de coexistência.

\footnotetext{
${ }^{96}$ NANCY, Jean-Luc, op. cit. p. 43.

${ }^{97}$ Idem, p. 48.

${ }^{98}$ SANTOS, Milton. A natureza do espaço: técnica e tempo, razão e emoção. São Paulo: Edusp, 2006. p. 60.

${ }^{99}$ NANCY, Jean-Luc, op. cit. p. 48.
} 
O que buscávamos, e continuamos buscando, é repensar o espaço da Universidade a partir do caráter performativo do papel do professor, nas palavras de Derrida, que "professa prometendo" e completa: "professar é se comprometer declarando-se". ${ }^{100}$ E foram muitas as declarações e foram muitos os gestos de companheirismo que nos permitiram escapar da fabulação para estarmos em plena ação. Para mim, o melhor entendimento do que significou participar de um programa de pós-graduação em humanidades, direito e outras legitimidades, e que se deu pela via da experimentação. Compreendendo que entre a performance e a experimentação, segundo Turner, o contido ou suprimido revela-se. Acrescento, revela-se comunitariamente.

Éramos nós a ocupar uma outra casa, o teatro no centro, na qual podíamos nos afastar da reprodução do saber ou de uma neutralidade distópica como proteção e inércia. Ao contrário, o que nos mobilizava era a possibilidade de uma nova cultura que incluía o cultivo das relações, o preparo de cada encontro, o fazer. O que nos movia era o relacionar-se como essência do avizinhar-se. A aventura de lançar-se na investigação e nas possibilidades de troca que apareciam a cada nova indicação de parceiros e participantes das aulas.

Como uma companhia teatral, tomados por um desejo comum, dávamos conta dos mínimos detalhes que sustentavam a nossa presença na Luz: da mobilização para garantir arrumação das cadeiras do espaço, arrecadação de itens de toalete para suprir o teatro, à doação de pó para café. Ali, também, experimentávamos a economia solidária que se articulava entre a oferta de carona até a arrecadação de dinheiro para a caixinha do teatro. Tudo isso é cultura, processo de cultivar a produção.

Contávamos, ainda com a presença do poeta Fábio Rodrigues dos Santos, que participou ativamente das aulas em vários dos cursos e teve uma banca garantida para vender suas Parangas poéticas. Fábio, como um dos moradores da região, sempre arrebatou a audiência nas aulas com seu texto crítico sobre a vida na Cracolândia. Conquistou, além do espaço de venda dos seus poemas, uma atuação constante nos encontros. Incentivado pelos professores, leu muito dos seus textos e, num dos cursos, passou a produzir poesia como síntese

${ }^{100}$ DERRIDA, Jacques, op. cit. p. 39. 
do que acontecia na semana anterior. Uma crônica poética, uma nova matéria possível de ser experimentada somente ali.

As novas humanidades defendidas por Derrida, quando ele pensa a Universidade sem condição, equilibram-se num tipo de proposta no qual "o acontecimento depende de um talvez que se afina não com o possível mas com o impossível." ${ }^{101} \mathrm{O}$ que escrevo sobre a presença do Diversitas na Luz carrega a emoção do que vivemos quando abraçamos o poder da dúvida. Não apenas como exercício de retórica, mas como força motriz da viabilização das propostas das disciplinas, e, por que não: como política universitária, compreendendo como tal a amizade pela cidade e a aproximação com o centro periférico e, sobretudo, a nossa amizade mesmo como grupo. Entre o fio da navalha do possível e do impossível, o comprometimento com a exposição/partilha das dúvidas revelou-se como a possibilidade de viver a Universidade numa via que promoveu uma aproximação mais espontânea com os participantes dos cursos.

Problematizamos a produção do saber, questionamos o lugar do professor e o porquê fazer pesquisa, lidamos com uma literatura que não chega dos cânones e que apresenta uma gramática viva que ninguém domina direito, ora melhor traduzida por uma performance de pole dance de uma atriz trans, ora coreografada por um mestre popular de matrizes africanas do candomblé de Alaketu, ou, ainda, registrada na poesia de Fábio Rodrigues:

Do concreto à poesia

De que valem

Métodos, formas?

Quanto pesam

Diretrizes, normas?

Pouco...

Quase nada...

Aproximo-me então das

Palavras

Entendendo ser a poesia

Não apenas mera obra

É sim força criadora

Dom, graça

Sublime, enlaça

${ }^{101}$ Idem. p. 79. 
Fábio Rodrigues

Os questionamentos que aparecem nos versos do poema Do concreto à poesia promovem esse alargamento no limite da pendulação entre o conhecido e o desconhecido, entre o inventado e o vivido, entre o que é possível conhecer quando esperamos encontrar apenas dor, desgraça, brutalidade e nos deparamos, também, com música, afeto e poesia. Quando nos surpreendemos com a força criadora da palavra.

Vale lembrar das raízes mortas apresentadas por "R" quando se referia à forma como enxergávamos os usuários de crack e das radículas que, mesmo escondidas, alimentam e comunicam-se. Diferentemente daquele momento no qual o músico nos enredava como expectadores daquela performance com sucatas, as aulas das quais Fábio Rodrigues participava já eram resultado de deslocamentos, mudanças de hábitos, desconstrução de repertórios. Estávamos, nós agora, a desenhar o diagrama intensivo, cheio de dúvidas diante da paisagem desconhecida, configurada à medida que criávamos esse espaço interno/externo a partir das perguntas recorrentes desse processo: "Será que isso vai funcionar? "Isso funciona ou não"?

\section{5. (IN)DISCIPLINA NO CENTRO DA QUESTÃO}

Derrida lembra Nietzsche para resgatar uma das propriedades mais subjugadas da filosofia que se localiza nessa borda da dúvida, entre o possível e o impossível, que é o talvez. Sem respostas, sem garantias, fazer as disciplinas acontecerem na Luz demandava colocar-se em exercício físico, emocional, com o dispêndio de uma energia que exigia do corpo outra postura para lidar com todo tipo de tensão característica de um lugar em disputa, com conflitos armados, com a opressão explícita da população local. E, por outro lado, que promovia o encontro antes da aula na lanchonete da esquina, a pizza depois do trabalho, a descoberta da vida cultural pulsante do centro, ali, diante de todos.

Descobrir-se entre outros na terra do talvez. Nesta fresta do contingenciamento, do condicional, nas ondas do possível e do impossível, nas quais a realidade bruta nunca foi ignorada, mas nunca imprimiu definitivamente todas as cores da Luz. O acontecimento e o conhecimento brilharam e brotaram no limiar dessa força. Derrida fala de uma gramática do 
condicional "se" no "e se?", que traz "o possível acontecimento do incondicional impossível". ${ }^{102}$ Como a ultrapassagem de um estreito, que segundo o filósofo só é possível nas humanidades, nos colocaria para além da oposição constatativo/performativo. Lugar que somente se alcança fora do contexto, da convenção, do contexto institucional.

A desinstitucionalização do ensino como parte de uma proposta institucional colocavanos diante desse paradoxo. Exigia que pensássemos na integridade física dos participantes e, a partir dessa inteireza, na forma mais honesta de descondicionarmo-nos sem fazer da experiência uma epifania banal, sem conexão com todas essas questões postas na integralidade do corpo que abraça a cidade como território de coexistência. Sob o convite feito por Derrida de pensar nas Humanidades que não deve se encerrar no dentro das Humanidades, forçando o limite do indizível e, em poucos e importantes momentos, dialogando com a população invisibilizada da Luz, resistir ao deplorável da política brasileira significou ganhar a rua por esse avizinhar-se. Cada professor sentiu-se desafiado, como registrei na sequência de entrevistas feitas com os parceiros Galeão, Bairon e Zilda, no primeiro encontro daquele semestre:

São Paulo, 14 de março de 2018.

Pessoal do Faroeste - O Lugar das Redes preservadas, descartas, compartilhadas e expandidas.

Luiz Guilherme Galeão da Silva, 47 anos, Professor Doutor, Dpto. de Psicologia Social e do Trabalho, IP, USP, há 9 anos.

Por que aderiu à proposta da disciplina de sair do Campus Butantã para dar aulas na Luz?

1 - Porque o Campus separa a universidade da cidade e dar essa disciplina na Luz desafia a gente a se reconectar com a cidade.

Qual sua expectativa dessa primeira aula do curso no Teatro do Pessoal do Faroeste?

102 DERRIDA, Jacques. A universidade sem condição. Tradução: Evando Nascimento. São Paulo: Estação Liberdade, 2003. p. 79. 
2 - Um público de alunos variados, desde alunos de pós-graduação até militantes. Homens, mulheres, negros, negras, brancos, indígenas... uma grande variedade de pessoas que estejam lá, pessoas que entrem pelo teatro e assistam às aulas... Uma expectativa de que a gente possa conversar com uma gama muito maior de pessoas com experiências e que a gente possa realmente pensar essa ideia de rede de resistência.

\section{Qual a sua aposta como possível resultado no final desse curso?}

3 - Que a gente compreenda melhor, todos nós, o papel das redes na formação de resistência e criatividade, de movimentos sociais e culturais, de propostas as mais variadas. Que a gente tenha conseguido ser um interlocutor para as pessoas que já estão fazendo essas redes, que essas redes já existem, e que a gente possa entender melhor como elas funcionam. Como as próprias pessoas do curso passem a refletir mais sobre o papel das redes nesse processo de resistência e criatividade.

Sérgio Bairon, Rei Congo do Estado de Minas Gerais, título acadêmico livre docente, há dez anos na USP, 58 anos.

\section{Por que aderiu à proposta da disciplina de sair do Campus Butantã para dar aulas na Luz?}

1 - Porque eu acho que é extremamente importante, e aprendi isso no campo (literalmente no campo) trabalhando com várias comunidades de tradição cultural afro ou indígenas, que para a gente conseguir teorizar de uma forma mais consequente, mais produtiva, a gente tem que viver ou melhor vivenciar com essas comunidades os acontecimentos que fazem parte do cotidiano de fato da vida delas. Eu acho muito difícil ficar falando de uma realidade que a gente não conhece na empiria que a gente não participou, não conseguiu refletir, estando dentro do contexto do qual a gente fala e muitas vezes escreve na academia. Então, eu acho que essa disciplina que no semestre passado foi chamada de lugar das memórias e, agora, lugar das redes, ela tem uma proposta de entrar no terreno, entrar no universo que nos interessa, nas temáticas que nos interessam, mas vivenciar com as pessoas que estão sempre tomando a frente nessas temáticas, nessas experiências e, no caso, os parceiros que teremos nessa disciplina, eles são fundamentais para isso, porque eles fazem uma espécie de interlocução com o pessoal - que a antropologia tradicional chama de interlocutores mesmo. Pessoas que não estão exatamente no objetivo final do teu diálogo, mas elas fazem uma interlocução poderosa com as pessoas que estão nesse terreno, porque elas também estão nesse terreno. 


\section{Qual sua expectativa dessa primeira aula do curso no Teatro do Pessoal do Faroeste?}

2 - Eu não tenho a mínima ideia, na verdade... E é bom, isso é bom porque de certa forma é isso que nós vamos enfrentar. Nós cometemos um grande equívoco no semestre passado, com a melhor das intenções, é claro. Nós dividimos as aulas entre os três professores, forçosamente tivemos que organizar aulas e dar aulas como nós fazíamos na universidade. Isso foi muito ruim, eu acho. Nesse semestre, a gente está tentando resgatar, o que até já é de certa forma tradicional no Diversitas, que são três professores conversando de uma forma "aleatória" muito pelo acaso, pela temática que surja...eu acho que a gente vai resgatar isso pra esse curso, que vai ser ótimo. Quer dizer, os professores falam a hora que bem entenderem... e eles são algumas pessoas que estão no meio de uma série de outras. Eles não são o centro da fala. Eu acho que isso a gente tem que exercitar nesse semestre. Porque é o que eu inclusive procuro fazer quando estou trabalhando com essas comunidades de tradição oral, que eu jamais chego lá sequer fazendo muitas perguntas também pra eles. Eu vou tentando construir uma relação de proximidade, de confiança mútua e a partir daí vão surgindo temáticas numa conversa muito amigável, pode se dizer assim... Eu espero isso aqui, nessa disciplina, nesse ambiente e com as pessoas que vão fazer parte. Eu acho que tem temáticas extremamente polêmicas, temáticas tensas. E eu espero que a gente consiga debater essas temáticas das mais variadas formas, dentre essas formas, alguns autores vão ser citados para quem se interessar pelo assunto. Mas eu acho que essa narrativa tradicional da academia ela deve ser um fio de uma grande costura na forma de trança, que a gente vai tentar fazer nesse semestre.

\section{Qual a sua aposta como possível resultado no final desse curso?}

3 - Tá no campo da utopia. Eu acho que nós estamos propondo a partir de uma rede local graças à historicidade dos contatos das relações, nós estamos tecendo uma rede local e, dessa rede local, a ideia que ela se expanda usando o máximo possível o digital para isso, mas que ela se expanda em força e em aquisição de outros parceiros... porque, afinal de contas, tem uma questão que sintetiza os contatos todos, que é uma questão central ligada à vida, ligada à resistência, ligada à busca, às conquistas, à questão do Estado, à questão da participação política e das transformações todas que nós buscamos, então, a ideia da rede nunca foi tão importante por um lado, por outro lado a gente não está partindo do princípio que a rede digital inaugura esse mundo. A gente está partindo do princípio - que a mim me agrada muito nessa experiência -, é que redes locais fixas, calcadas no cotidiano, que só pode ser, evidentemente, na relação física com o território. Esse cotidiano é que vai nos 
trazer as questões e que vai inclusive demandar uma expansão da ideia de rede.

Zilda Iokoi, 71 anos, Professora Titular no Dpto. de História. Fundadora do Diversitas. Desde 1971, como estudante ligada à USP. 37 anos como professora. 1 ano de jubilada.

\section{Por que aderiu à proposta da disciplina de sair do Campus Butantã para dar aulas na Luz?}

1 - Há muitos anos estou refletindo com os meus estudantes a impossibilidade de no Campus fazer alguma coisa nova de alteração da vida social. Pra isso, fiz trabalhos em Diadema durante dez anos, fiz trabalhos na periferia de SP, Piracicaba. Todo o tempo estou buscando um jeito de sair do Campus por que ali é um simulacro de um tempo estabelecido em que o novo tem poucas chances de entrar, a não ser que ele se conforme numa estrutura acadêmicouniversitária como o Diversitas. Saímos de lá várias vezes já. Precisamos pensar a nossa incursão na cidade porque a cidade é o lugar das relações sociais mais complexas, a cidade é o teatro da modernidade, a cidade é o templo da violência, da repressão, mas também da criatividade, e foi no momento em que eu criei o meu projeto de pesquisa contemporâneo, que é "A cidade prende, a arte liberta", e com a sua colaboração nos instalamos no Teatro do Faroeste.

\section{Qual sua expectativa dessa primeira aula do curso no Teatro do Pessoal do Faroeste?}

2 - Primeiramente, uma surpresa gostosa do grupo que nós tivemos no semestre passado praticamente retornando todo. É muito bom quando você percebe que houve uma repercussão, que os alunos compreenderam a nossa discussão, que se integraram nesse espaço, compreenderam a importância de a gente transformar o espaço da cidade num espaço diversificado. Porque nós nos instalamos num espaço que estava restrito à Cracolândia e fazendo com que as forças da repressão pudessem agir e atuar de uma maneira arbitrária sem ninguém para observar. Quando pensei em sair do Campus era isso: vamos ocupar a cidade porque não é possível que nós deixemos os pobres e oprimidos e moradores de rua serem violentados pelo prefeito João Dória, dessa maneira como foi nesse ano de 2017 e agora no 2018. Nos piores dias do frio da cidade, atacar as crianças, as pessoas, as mulheres, com carro pipa e água gelada em cima das criaturas e depois colocar um trator para derrubar o espaço onde os moradores estavam dentro. Acho que nunca vivi uma situação tão arbitrária como essa, tão violenta, tão discriminadora, por uma 
figura tão abjeta que é o prefeito da cidade de São Paulo. Se não tivéssemos feito esse esforço eu ia ter uma decepção muito grande na minha vida pessoal. Ali, nos deu uma coisa linda. Hoje, nós somos integrados na cidade, com pessoas tão diversificadas. Pessoal da Mungunzá trazendo cultura, acolhimento, possibilidade de crescimento. Nós estamos ainda na Casa Florescer, resquício da administração do Haddad. Um lugar que acolhe todas as diversidades sexuais num apoio fundamental para as pessoas sobreviverem nesse mundo da discriminação. A Florescer, hoje, pra mim, é um lugar que me dá um encantamento enorme. Estou lá gravando histórias de vida das mulheres trans e histórias tristes, valentes, complexas relações familiares de várias partes do país que vai nos dar a possibilidade de compreender de uma outra maneira a sobrevida dessa situação em que o corpo e definição humana genética não tem a ver com as determinações que a natureza dá ao próprio corpo. E a desgraça que é viver um corpo desses, porque muitas das histórias das pobres mães vinculadas com as teorias mais arbitrárias dos pentecostais e dos evangélicos expulsam suas crianças com 7 ou 8 anos de casa porque estão vestindo roupa de menina. A ignorância como elemento de desumanização dessas mães e o sofrimento de ambas as partes. E tem o Beto, que é o coordenador da Florescer, que é uma figura incrível. Estou muito feliz de estar nesse lugar que me humaniza muito. Pude comprar uma cadeira de rodas pra Suzana. Essas coisas é que vão me humanizando... me permitindo coisas novas. Estou ficando outra pessoa nesse lugar.

\section{Qual a sua aposta como possível resultado no final desse curso?}

3 - Nós temos que fazer dela uma agregação de pessoas as mais diferentes pra gente continuar o processo de investigação e imersão. Não é justo que as pessoas que estão conosco fazendo um curso não tenham da nossa parte oferecimento de um prosseguimento de trabalho. Eles são estudantes de pósgraduação, pleiteantes à pós-graduação. Já profissionais formados e que estão esperando da gente um caminho, uma possibilidade. Acho que temos que oferecer para uma continuidade que nos leve também a uma continuidade. De continuar na cidade. De garantir que eles tenham esse lugar de reflexão e crítica desse monolitismo da cultura acadêmica que parece que isola as pessoas ao invés de integrá-las. Nós temos que pensar uma proposta para que essa quantidade imensa de pessoas prossiga fazendo algumas coisas. Devemos oferecer umas quatro possibilidades: produção de arte, ensino e troca. Investigação e solidariedade. Fazer desse compromisso com a cidade que precisa ser desvendada, revelada. Transformar a cidade num lugar de liberdade. Fazer uma mostra de cinema imensa sobre a cidade e como as pessoas se perdem na cidade e podem ser encontradas. 
As entrevistas sinalizaram a passagem do tempo e o enredamento dos docentes com o território. Assim como observei o mesmo processo acontecer comigo desde que escrevi o primeiro texto sobre a Luz para o blog A vizinhança, em 2014, pude observar essa mudança, também, com os professores.

Num primeiro momento, em 2016, via Coletivo Diversitas, as pautas objetivavam uma série de reivindicações diante de um panorama político geral, que, do ponto de vista pragmático, era inalcançável na esfera da atuação concreta do nosso grupo, como podemos constatar no trecho do manifesto de lançamento do Coletivo: "A articulação entre membros do parlamento, do executivo e do judiciário, apoiados pela mídia monopolista, opera de forma organizada para a preservação de assimetrias econômicas, sociais e políticas, e é fortemente protegida pelo braço armado das polícias militar e civil, dentro e fora das delegacias. É preciso responder à altura.”

No mesmo Teatro do Pessoal do Faroeste, no primeiro dia de aula da pós-graduação, passados quase dois anos, as entrevistas feitas com parte do mesmo grupo de professores apontavam um outro discurso. $\mathrm{Na} \mathrm{Luz}$, a micropolítica permitia-nos um engajamento de fato naquela vizinhança e uma atuação efetiva fora do contexto institucional da Universidade de São Paulo. Segundo Luís Galeão: “Que a gente tenha conseguido ser um interlocutor para as pessoas que já estão fazendo essas redes, que essas redes já existem, e que a gente possa entender melhor como elas funcionam." Na voz de Sérgio Bairon: "Eu vou tentando construir uma relação de proximidade, de confiança mútua e a partir daí vão surgindo temáticas numa conversa muito amigável, pode se dizer assim..." e segundo, Zilda Iokoi: "Transformar a cidade num lugar de liberdade."

Esse processo de avizinhar-se da Luz também se refletiu no ajuste de foco de cada nova proposta de ementa ao longo do período, 2017-2019, e consequentemente das atividades planejadas. Se na primeira edição, no segundo semestre de 2017, o desafio foi chegar ao território, reavivar as memórias, conhecer os interlocutores, convidar a comunidade para os encontros dentro do teatro, em 2018, o roteiro desenhado refletia outro momento, priorizávamos a circulação pelos endereços da rede local e a ideia de que os grupos de alunos realizariam uma série de atividades que se pautariam pela escuta ativa das demandas dos parceiros: Casa Florescer, Cia. Mungunzá e Cia. Pessoal do Faroeste. 
Contávamos com uma outra articulação importante, a participação de alunos da disciplina Produção Audiovisual em Comunicação Digital II da graduação em Relações Públicas, Propaganda e Turismo, da Escola de Comunicação e Artes (ECA), que desenvolveriam registros audiovisuais com o objetivo de produzir conteúdos de interesse dos três parceiros. Alguns grupos conseguiram trabalhar junto com alunos da pós-graduação num diálogo que incentivamos muito naquele semestre.

Contatos pontuais, mas delicados. Sempre pensados para criar atividades multissensoriais, nos termos nos quais tentávamos nos nivelar sem grandes diferenças e abrir um canal para que as tensões se diluíssem minimamente quando o desafio era a aproximação com as pessoas do território. Alberto Silva, gestor da Casa Florescer, ensinou-nos muito como música, lanches coletivos, oficinas de dança afro, performances de lip sync e outras pautas agregadoras que funcionavam como start para um entrosamento amistoso com a mulheres trans. Minha atenção sempre se voltou para alguns detalhes e para o esforço de perceber a delicadeza dessas aproximações, a responsabilidade de não reproduzirmos situações, conteúdos, relatos dessas visitas, tal qual Viveiros de Castro compreende como função meramente expositiva da etnografia.

O esforço concentrou-se em andar, caminhar muito, explorar solitariamente o que podia apreender com os limites do que não me caracterizava como um local, alguém naturalizado na Luz. A observação sem pudor para registrar com os olhos e com o meu caderno informações que pudessem me ajudar a não reproduzir idealizações e, quando muito, criar algumas rubricas para partilhar com professores e alunos.

Nessas andanças algumas cenas foram marcantes: caminhava pela Rua Prates, no Bom Retiro, na altura da lateral do Parque da Luz, numa tarde qualquer, e enquadrei diante de mim uma das residentes da Florescer. Reconheci-a e preparei-me para cumprimentá-la. À medida que nos aproximávamos, numa linha nem tão curta assim, reparei que ela jamais levantava o olhar do chão e que passou ao meu lado sem fazer contato visual comigo. Comento com o gestor da Florescer o ocorrido e constato que é uma prática recorrente entre as mulheres trans que circulam no centro de São Paulo e tem a ver com autoproteção. Invisibilizar-se para sobreviver e escapar das provocações e de possíveis agressores. 
Outras cenas registradas têm a ver com a banalidade do abandono que provoca microviolências como um pachwork da miséria na região da Luz: flagrar um cachorro ávido de fome comendo as fezes dos cavalos da polícia militar na Rua dos Gusmões ou ser alvejado por uma chuva de baratas mortas, varridas da soleira de um sobrado numa tacada só, como se o excesso trouxesse outra dimensão do convívio com a falta de dignidade na rotina por detrás daquela porta do cortiço.

\section{DESCONTINUIDADE, CONTINUIDADE: COMUNIDADE.}

\section{A PROXIMIDADE DA RODA}

Em paralelo à produção das aulas, mantive outro canal ativo com apoio dos professores e da Cia. Mungunzá. Conduzi nove sessões de terapia comunitária na geodesia situada no pátio do Teatro de Contêiner. Os encontros intitulados primeiramente como "Cuidadores na Luz, roda de conversa", depois, "A vizinhança na Luz", aconteciam no final da tarde do mesmo dia que tínhamos as aulas à noite. O objetivo era acolher prioritariamente os agentes de saúde, os assistentes sociais e os ativistas com o propósito de literalmente cuidar de quem cuida e manter a nossa presença na Luz alinhada com uma oferta de ajuda para restituir o que recebíamos nas participações em aula, bem como proporcionar uma espécie de acolhimento geral no território.

Nessas rodas, com a participação desses interlocutores que atuavam diretamente nas atividades de pronto atendimento à população da área, eram notáveis a fadiga e a falta de horizonte, passado pouco mais de um ano da mudança na gestão municipal. Os relatos da precarização dos serviços e todos os desmontes que já haviam sido promovidos na rotina de trabalho compuseram o pano de fundo dos encontros. Alguns dos participantes chegavam para partilhar o desligamento do emprego, o inconformismo com a interrupção de projetos que começavam a entrar numa curva ascendente de resultados e, sobretudo, a flagrante perda de vínculo com alguns dos usuários de crack que tinham buscado algum tipo de assistência. 
Lamentavam o sumiço geral de algumas dessas pessoas por conta das perseguições e investidas violentas da Guarda Civil Metropolitana, que contribuíam diretamente para essa desorientação.

Como vimos no memorial, na página 31 , toda roda comunitária passa pela escolha de um tema e contextualização. Nesse período, a latência dos acontecimentos, o sentimento geral de obstrução dos trabalhos aparecia nas propostas a serem debatidas, como: "a tristeza diante do fracasso", "a desolação diante da apatia", "uma inquietação pela vontade de fazer mais", "o medo do novo", "o desafio de controlar a ansiedade", "o cansaço da exploração da miséria na Cracolândia", "o estranhamento diante do estado da cidade".

Quando os temas eram contextualizados, reconhecíamos nos detalhes apresentados o tipo de tensão presente na área. Apareciam queixas como a do barulho intermitente de helicóptero, sinal de ação policial ou da imprensa, que, segundo um dos participantes, mantinha distância estratégica para "não pisar no chão, nem olhar nos olhos dos moradores". Numa das rodas, duas crianças da vizinhança do teatro, que estavam a brincar no playground, começaram a nos interromper de forma desafiadora e curiosa. Uma delas, o único depoimento infantil que registrei ao longo da pesquisa, nos disse: "eu sou o senhor das terras".

“O medo do novo" venceu em votação outro tema: "o desafio de controlar a ansiedade", mas como a roda é generosa sempre parece haver uma convergência que permite que o tema escolhido sirva para desenvolver as questões sob o prisma de cada um. Foi o caso de "A", usuário de crack, morador do Atende em frente ao teatro. Ele negociou seu pernoite com o técnico e foi liberado para participar do encontro, que ultrapassava a hora limite de apresentação no portão do Atende como regra para garantir o leito no albergue. Sua vontade de estar na roda tinha a ver com a demanda de partilhar o desafio de controlar a própria ansiedade, por conta de uma entrevista de emprego no dia seguinte. Algo que ele próprio reconheceu como "o medo do novo", tema escolhido pelo grupo e proposto por "C", aluna ouvinte da disciplina.

Em outra sessão, pudemos contar com a presença de "A", profissional da saúde com dez anos de experiência no território, recém-demitida do posto de trabalho, mas com um sorriso generoso incapaz de ceder à própria preocupação. Sua fala foi muito importante para nos trazer outro recurso da roda: afetar positivamente a todos os participantes nos oferecendo um nível sutil de força num momento de fragilidade. Uma mulher negra, mais velha, mais experiente, capaz de olhar para os ciclos e expressar uma resiliência genuína. 
Nesse dia, éramos uma dupla de terapeutas a conduzir os trabalhos. Maria Claudia, minha parceira naquela roda, tinha vindo do Rio de Janeiro especialmente para conhecer nosso trabalho na Luz e me orientar com sua ampla experiência em terapia comunitária. Acabamos, como muitas vezes acontece nessas rodas, aprendendo a partir da escuta. "A" tinha um jeito de olhar a vida no qual, no término do encontro, cabia apenas agradecer.

Entretanto, na maioria das vezes, fiz a gira acontecer sozinho, iniciando o trabalho quase sempre uma hora antes de começar os encontros, numa jornada que totalizava cinco horas somadas com o tempo regulamentar da aula na sequência. Compreendia que garantir água, frutas ou snacks de cortesia, no limite dos meus recursos financeiros para produzir essas ações, era o jeito possível de acolher e expressar cuidado. A geodesia da Mungunzá é um projeto de execução muito simples e eficiente, pela arquitetura abobadada que garante um conforto acústico, se considerarmos que se localiza na ponta do terreno, precisamente na esquina do quarteirão com trânsito mais intenso. Dada a realidade da sujeira e do mal cheiro naquele pedaço, passei a defumar o espaço com o mesmo defumador que minha tia usava no próprio terreiro para fazer os atendimentos. Tudo isso conecta-se numa vizinhança pela amizade que veremos adiante.

Terminar as rodas procurando compor a circunferência mais redonda possível, na qual a lateral de cada pé se apoia na lateral dos pés dos respectivos vizinhos, à esquerda e à direita, permitindo que, ao final, todos abraçados, a roda balance de um lado para o outro sem provocar nenhuma queda, sempre foi um jeito marcante de experimentar um tipo de confraternização final. Esse momento, no qual estamos apoiados nos ombros e cinturas dos outros, sem necessariamente sabermos quem são esses outros, produz um alento, um embalado, um acalanto, que nunca pude proporcionar nos encontros da Luz.

O desafio passava por respeitar situações nas quais o corpo como casa muitas vezes tinha sido violentado e, no limite, representava um tipo de autodefesa intransponível para quem está em situação de rua. Por outro lado, era necessário pensar qual apelo era possível para propor algum nível de confraternização numa região em permanente estado de guerra. Invariavelmente, além da água e alguma fruta, partilhávamos no final da sessão uma palavra que traduzisse o que cada um levava daquela roda, daquele encontro. "Carinho", "paz", 
"alegria", "força", “emoção", “aconchego", "surpresa", "acolhida”. Exemplos das palavras partilhadas para fechar o círculo daquela vizinhança de hora e meia.

Pela via da confraternização, a roda permitia coaparecer. Ideia muito bem sintetizada por Marcia Shuback, ao pensar o conceito proposto em A comunidade inoperada: "ser é aparecer, afirma igualmente que ser-em-comum é co-aparecer ou, na terminologia proposta por Nancy, que ser-em-comum é uma 'comparição"'. 103

A roda é uma síntese concreta da vizinhança pela palavra, na qual entre a fala de si e a escuta do outro e, por consequência, a escuta de si, cria-se um lugar comum para a coexistência desse entre que revela o território da comunicação. Como enfatiza Nancy, no ato de coaparecer, essa comparição reforça a aparição do entre nós. Ele destaca que esse nós, esse entre nós que abriga tu e eu, o e tem menos valor de justaposição e mais de exposição. O que nos permitiu, mesmo sob o céu implacável dos motores de helicópteros e das investidas policiais, fazer brotar as palavras que, distantes da opressão, no chão daquele lugar, revelavam o que cada um sentia no círculo. Dessa literatura, cavamos a revolta, a solidariedade, o abandono, o pedido de ajuda. Não buscávamos saída e nem era esse o objetivo. Experimentávamos estar juntos na diversidade de falas, afetos e mentalidades, e esse estar ganhava a qualidade da partilha. O desejo de amizade na polis.

Sim, tratava-se de um comparição numa parte da cidade em guerra: helicópteros, balas de borracha, jatos d'água, baratas vivas e mortas, fezes humanas para todos os lados, falta de condições mínimas para a higiene pessoal, foco de doenças contagiosas, presença abundante de consumo de bebidas alcoólicas e de consumo de crack. Prédios abandonados, ${ }^{104}$ prédios ocupados ameaçados de despejo. Qual o limite do avizinhar-se na Luz? Essa pergunta retorna infinitamente nos pequenos detalhes.

$\mathrm{Na}$ falta de um código comum, mesmo para os técnicos que atuavam no front, cada profissional ia descobrindo a melhor abordagem e/ou o ponto necessário para garantir qualidade

\footnotetext{
${ }^{103}$ NANCY, Jean-Luc. A comunidade inoperada. Rio de Janeiro: 7Letras, 2016. p. 16.

${ }^{104}$ De acordo com dados do Plano Municipal de Habitação, a cidade de São Paulo precisaria de 358 mil novas moradias para zerar seu déficit habitacional. De acordo com o mesmo relatório, a capital paulista possui 1.385 imóveis ociosos, abandonados ou subutilizados em terrenos vazios. Disponível em: https://jornal.usp.br/podcast/momento-cidade-14-por-que-temos-tantas-casas-vazias-em-sao-paulo/. Acesso em: 22 Dez. 2020.
} 
na execução do próprio trabalho. No caso dos hotéis sociais ainda operantes, que refletiam um dentro/fora sem tréguas, com ambientes que reproduziam o humor das ruas, encontrava-se boa parte do refluxo da vida nas calçadas.

Em rodas de conversa sobre rotina de trabalho, sempre ouvia a queixa da parca oferta de orientação por parte das organizações sociais de saúde, gestoras dos serviços terceirizados, capazes de deixarem os técnicos expostos a todo tipo de litígio entre o staff dos hotéis e os usuários, sem respaldo para toda a sorte de problemas geradores de conflito nos espaços coletivos: consumo de crack, furto, crises passionais, problemas com as instalações dos banheiros sem higiene, tubulações quebradas, infiltrações nos cômodos etc.

Nos dois hotéis sociais que pude frequentar ministrando uma oficina de palavras e sonhos para os usuários, prevaleciam os arranjos do corpo técnico para lidar com tamanha adversidade e falta de infraestrutura para trabalhar. As soluções eram tomadas de acordo com o que o grupo decidia na sua unidade, ou, em certos casos, de acordo com o que o técnico individualmente avaliava. "R", coordenador técnico do Hotel Zezinho 2, me acolheu com a generosidade que sempre demonstrou na própria condução da equipe. Seu comprometimento com o ofício explicitava suas apostas. Sempre afeito às confraternizações, sempre atento e de prontidão para mediar conflitos. Contraiu tuberculose no atendimento aos residentes. Mais tarde perdeu o posto de trabalho com as conclusões das reformas no modelo de atendimento proposto pela gestão Doria.

As atividades serviram para conhecer melhor a realidade das condições de trabalho desses profissionais. "L" junto com "AP" formavam uma dupla muito entrosada na coordenação técnica do Zezinho 1, unidade de hotel social também situada na Rua do Triunfo, voltada para o público feminino. Parceiras que também acolheram a oficina de palavras e sonhos que realizei com as residentes, elas participaram das atividades com um engajamento que refletia a qualidade do trabalho desenvolvido na unidade. Mas o nível de exposição a toda sorte de problemas administrativos e de litígios era frenético e total. Num dos encontros, soube que, pouco antes da nossa agenda, ao abrir a porta do escritório depois de mediar um conflito, uma das pessoas da equipe levou um banho de café de uma residente que tinha a intenção de vingar-se. Por sorte o café da garrafa térmica estava frio. 
Numa das agendas no Zezinho 1, conheci uma mulher com uma presença forte. "S" frequentava a Cracolândia há três décadas. Naquele momento, aos cinquenta anos, tratava um câncer. Mulher negra imponente, tocava violão, mas tinha vendido o que ganhou por R $\$ 20,00$ para comprar uma pedra de crack. Entre muitas oscilações, no que me parecia ser a relação dela com o fluxo, disse-me uma frase que foi a chave para eu compreender do que se tratava a questão daquela população de usuários e a responsabilidade que assumíamos de imediato, todos nós, incluindo os mais jovens da graduação, em maior ou menor escala, e às vezes sem elaborar muito. Com olhar expressivo, voz colocada e a pele muito negra, me encarou e disse: "ninguém nasce com uma mamadeira de crack".

Ouvir essa frase e ver aquelas pessoas na diáspora da Cracolândia não deixava mais nenhuma dúvida sobre o limite do avizinhar-se na Luz e, consequentemente, do fluxo, em consonância com o que declarou em entrevista à Ponte Jornalismo, o psiquiatra, palhaço e ativista Flávio Falcone:

"Os negros foram jogados para as praças sem roupa, sem casa e depois veio a lei da vadiagem e afins. A Cracolândia é o fantasma do dia seguinte da abolição, um problema estrutural da sociedade que não queremos olhar", definiu o especialista, que critica a pouca visibilidade dada à questão racial. "[O vício em crack $]$ É uma questão social, é óbvio", prosseguiu. ${ }^{105}$

\section{OS TRABALHADORES DA LUZ}

No oposto dos que lidavam com a mediação institucional, às vezes de forma muito miúda na filigrana do dia a dia, foi possível reconhecer outra força tão importante quanto a desse quadro técnico formal: os independentes. Eram os ativistas, artistas, ex-funcionários, frequentadores do pedaço ou simplesmente moradores da área que buscavam ocupar o espaço público para promover algum tipo de integração, geralmente descolada de um macroprojeto ou de uma agenda oficial. Dentre os perfis desse grupo, vale destacar a figura do "trabalhador da Luz", pessoa que buscava um espaço de expressão, um grupo para coaparecer.

105 Disponível em https://ponte.org/pesquisa-na-cracolandia-mostra-maioria-negra-e-numero-questionavel-domercado-do-crack/. Acesso em: 22 Dez. 2020. 
Independentemente de ter ou não emprego, ou, ainda, à revelia da rotatividade de postos de trabalho, capaz de levá-los de uma instituição a outra, de uma bandeira a outra, sem condição de escolha na luta pela sobrevivência. Pessoas que desejavam trabalhar na criação de um espaço tal qual vimos na definição de Milton Santos: um eixo de relações.

O perfil do "trabalhador da Luz" talvez seja o mais abrangente por aglutinar todo o tipo de gente, capacitada tecnicamente ou não, em diferentes áreas, que acreditavam nas práticas de redução de danos ou simplesmente que estavam dispostos a trabalhar pela inclusão social e pela desestigmatização da população da Cracolândia. Ou, ainda, como vizinho para atuar em prol da qualidade de vida no seu entorno.

Importantes no protagonismo das iniciativas de confraternização, pelo conhecimento em rede e pela disponibilidade para o território, eram capazes de encontrar com muita criatividade soluções para todo o tipo de desafio na produção de eventos, que aconteciam basicamente pelo esforço solidário.

A tônica desse grupo era a inserção dentro do ecossistema do fluxo sem nenhum tipo de distinção, pela via de um coleguismo, que sem dúvida promovia um elo afetivo. Mas, invariavelmente, apontava um mimetismo capaz de radicalizar a adesão à causa e de expressar uma intolerância às diferenças ideológicas, em qualquer negociação com autoridades e oponentes.

Do conjunto de iniciativas promovidas por esse grupo, e por conta do canal de diálogo que conquistamos com eles, pudemos participar de duas festas dentro do fluxo com barracas de atividades do Diversitas, a festa junina e a festa das crianças, nesse mesmo primeiro semestre de 2018. Essas experiências nos deram outro nível de inserção e conhecimento daquela realidade, contamos com a presença dos alunos na pré-produção e na atuação in loco.

Naquele momento, nossa agenda estava cada vez mais complexa devido à ampliação das frentes no território, alguns dos participantes das nossas disciplinas assumiram um protagonismo estratégico para a viabilização das atividades. O Lugar das Redes deixou de ser um título de ementa para ganhar corporeidade na cidade e lá estávamos todos em ação. Dos registros audiovisuais de Débora de Proença e de Thomaz Pedro à coordenação da produção de brindes e ambientação das barracas para as festas, nosso grupo partilhava outros saberes 
generosamente ofertados pelos próprios colegas. Essa horizontalidade trouxe um engajamento capaz de garantir destaque e profissionalismo ao trabalho do Diversitas nesses microeventos.

Boa parte da produção e execução das propostas ficava por conta das oficinas promovidas pela cenógrafa Angela Maciel Barbosa, aluna ouvinte de várias das disciplinas no território. Assim como outros simpatizantes das aulas na Luz, a atuação dela legitimava a interdisciplinaridade pela via da audiência estendida. Junto aos vizinhos do pedaço, alunos e artistas, as atividades de confecção de adereços, coordenadas por Angela, davam-nos a chance de corresponder a algumas das expectativas da disciplina de "entender melhor como as redes funcionavam", "construir uma relação de proximidade", "transformar a cidade num lugar de liberdade".

Por conta dessa articulação, passamos a integrar a rede local dos Sem Ternos, grupo articulador das atividades no território e que leva esse nome como fina ironia para marcar posição contrária aos seguranças da Porto Seguro, empresa que protagoniza a pressão pela nova ocupação de uma parte importante do bairro, com prédios comerciais e pessoas de terno. Fui reconhecido pelo grupo como um "trabalhador da Luz". Meu celular, como o ponto de contato do Diversitas com o território, passou a receber convocações para reuniões, comunicados de desaparecimentos da população em situação de rua, mensagens de despedidas dos profissionais demitidos, pedidos de ajuda emergencial e, sobretudo, alertas das operações com helicópteros da polícia. O convite para integrar essa rede trouxe um grau de aproximação com esses intermediadores que atuam em outras frentes para além dos teatros e da Casa Florescer.

A relação também dava-se de maneira distinta. Se no ambiente da cultura puder ser reconhecido como um igual, no grupo dos Sem Ternos ficava explícita a minha falta de domínio dos códigos, a falta de histórico nas instituições locais e, sob o guarda-chuva institucional da USP, o lugar que me reservavam. Sempre fui tratado com respeito, mas com distanciamento e pragmatismo. A abordagem invariavelmente estava circunscrita a saber como o Diversitas poderia ajudar. A troca era satisfatória, conseguíamos contribuir com agilidade e autonomia para as festas acontecerem e, em contrapartida, tínhamos em tempo real a temperatura dos acontecimentos na Luz, do ponto de vista de quem está circulando e chegando aonde não chegávamos. 
Com os Sem Ternos pude compreender melhor as dificuldades gerais na rotina deles e presenciar a deterioração das condições de trabalho no território. Vale observar que a comunicação nesse grupo de whatsapp expressava, e expressa, o que Nancy, ao citar Bataille, apresenta como a exposição ao outro que possibilita o desencadeamento de paixões. Comunicação como sinônimo de contágio, ${ }^{106}$ pautada pela exposição das singularidades e situações muito distintas dentro do grupo. Entretanto, por tratar-se de algo constituído como oposição ao establishment - pelo nome Sem Ternos já é possível localizar esse arranjo - e por organizar-se de maneira espontânea, era possível registrar a demanda comum da partilha dos sofrimentos, dos excessos, das queixas, do humor característico do lugar de fala, que encontra na paixão a forma de comunicação.

Dos principais articuladores dessa rede, existe o coletivo Craco Resiste, que é composto por um grupo de ativistas e atua dentro do fluxo, conhece bem de perto a rotina da Cracolândia e costuma ser a voz da insurgência que chega à mídia. Com integrantes que tiveram rotina de trabalho dentro da cena de consumo, apostam na confraternização como uma das estratégias para a redução de danos. São os principais articuladores do "Blocolândia" o bloco de carnaval da Cracolândia.

Em 2019, com a escalada da tensão policial na Luz, o carnaval passou a ser a única atividade de confraternização que continuou a mobilizar os Sem Ternos no território. Foi intenso o esforço na convocação de músicos, para conseguir instrumentos emprestados, bem como para articular a doação de água mineral e kits de higiene pessoal para serem distribuídos aos usuários. O cumprimento da burocracia municipal foi outra exigência que funcionou como um entrave para a liberação da festa no fluxo. Ficou explícito a queda de braço entre o poder público e os ativistas sobre o direito à ocupação do espaço da Cracolândia e o direito ao lazer daquela população.

Todas as mudanças ocorridas na região, desde 2016, repercutiram diretamente no eixo de relações e na (im)permanência do contingente de usuários naquele pedaço da Luz, bem como na esfera de atuação dos profissionais de saúde e de assistência social. Na falta de dados consolidados que garantissem uma visão holística, com informações mais atualizadas sobre

${ }^{106}$ NANCY, Jean-Luc, op.cit. p. 65. 
essa complexa teia de relações institucionais, interdisciplinares e politicamente divididas, entrevistei Maria Angélica Comis, psicóloga, redutora de danos, coordenadora do Centro de Convivência É de Lei, organização sem fins lucrativos que atua desde 1998 na promoção da redução de riscos e danos, sociais e à saúde, associados ao uso de drogas, sobretudo em contextos de vulnerabilidade.

O trabalho do É de Lei é diversificado, eles atuam diretamente na cena de consumo na Cracolândia e, também, com vários núcleos temáticos: Ensino e Pesquisa; Comunicação e Advocacy; Gestão Estratégica e Operacional; Prática de Redução de Danos, Campo, Centro de Convivência, Cultura e Projeto ResPire, estratégia que os coloca na rede intersetorial, na academia e na gestão pública com o principal objetivo de "transformar a lógica de guerra às pessoas". 107

São Paulo, 11 Nov 2020

Maria Angélica Comis, Psicóloga, Redutora de danos, Coordenadora do Centro de Convivência É de Lei.

No período 2016-2019, o que mais chamou a sua atenção na condução das políticas públicas de assistência social e de saúde na região da Luz?

Teve uma mudança brutal em relação à postura da Guarda Civil Metropolitana (GCM), a partir do resultado da eleição municipal de 2016. Nós tínhamos um Secretário de Segurança Urbana, Benedito Mariano, que também era coordenador do De Braços Abertos, lá na Cracolândia, e por isso ele conseguia garantir menos violações. Com o resultado das eleições, os guardas tornaramse muito mais violentos porque era inevitável a queda do coordenador com a mudança de Governo.

Em relação às políticas de assistência social e de saúde, observamos uma grande disputa de protagonismo, uma falta de intersetorialidade. Existia uma agenda de reuniões de comitê intersetorial, mas na prática não existia nenhuma conversa com a ponta que executava as políticas, fato que dificultou a articulação de ações. E por conta dessa disputa de protagonismo, o Programa Redenção, que estava sediado na Saúde, não conversava com a Saúde Mental. O coordenador que era o Arthur Guerra, na época, não tinha voz na Secretaria da Saúde, por isso mudou a coordenação do Programa que foi para a Secretaria

${ }^{107}$ Disponível em https://edelei.org/home/sobre-nos/ Acesso em: 22 Dez.2020. 
de Governo, e, hoje, sabemos que informalmente está sediado na Assistência Social.

\section{Como avalia o impacto dessas mudanças na vida da população em situação de rua e na realidade dos usuários de crack da Luz?}

O impacto foi avassalador. Primeiro, por que a gente percebeu que, entre outubro de 2016 e o início de 2017, muitas pessoas que eram beneficiários do Programa De Braços Abertos passaram a se desorganizar, principalmente por conta da propaganda política do Dória, que prometia acabar com o DBA. Muitas pessoas voltaram a viver no fluxo, começaram a montar barracas perto da Tenda do DBA com o intuito de garantir uma visibilidade, uma possibilidade de ser enxergado e não ser despejado dos hotéis.

Na mesma perspectiva, qual foi o cenário para os profissionais da assistência social e da saúde que atuavam no território?

Em janeiro de 2017, toda a coordenação do DBA, que tinha quatrocentas e sessenta pessoas sob sua responsabilidade, foi exonerada. Eu não fui demitida, mas fui proibida verbalmente de ir à Cracolândia e de fazer qualquer coisa em relação ao DBA. As equipes ficaram sem direcionamento e sem as reuniões semanais.

Outro aspecto é que a falta de intersetorialidade atrapalhou muito o fluxo de encaminhamentos. Pessoas que eram acompanhadas pelo Consultório na Rua passaram a ser atendidas pelo Redenção na Rua, que tem como característica mais o foco no uso de drogas do que a saúde integral. Houve a diminuição do serviço de abordagem e muita restrição na atuação dos trabalhadores. Passaram a não poder mais entrar dentro do fluxo para fazer atendimento, somente autorizados. Perderam a voz como técnicos junto a gestão e isso se refletiu na lida com os usuários.

Em maio de 2017, diversos outros trabalhadores de serviço de abordagem e assistência social foram deslocados de outras regiões para fazerem um mutirão na Cracolândia. O intuito era o de apelar para as pessoas se internarem nos hospitais psiquiátricos que foram conveniados naquele momento.

Os trabalhadores passaram por muitas dificuldades. Perderam o espaço de articulação de rede e sofreram demissões por conta de perseguições políticas. $\mathrm{O}$ impacto na vida das pessoas foi real porque o vínculo que elas tinham com esses trabalhadores foram rompidos e novos trabalhadores chegaram sem qualquer tipo de experiência para atuar junto daquela população.

A tenda do DBA passou a se chamar Atende 2, estava com uma OS nova chamada Inforedes, que não entendia nada do trabalho que era realizado ali. Basicamente eles foram aparelhados pelo poder paralelo. Os técnicos ficaram reféns desse mecanismo que passou a dominar o território. Se o poder público 
tivesse se articulado provavelmente isso não aconteceria. O território ficou mais hostil, com mais violência policial, afetando a saúde mental dos trabalhadores e impactando o atendimento da população.

Diante dessa desorganização em cadeia exposta por Maria Angélica e também presente nos relatos partilhados na roda, alguns desafios ganharam outros contornos dentro do que nos propusemos na disciplina $O$ Lugar das redes preservadas, descartas, compartilhadas e expandidas. Como reflexo dessa série de fatos ocorridos na região da Luz, entre o final de 2016 e todo o 2017, percebíamos esse impacto na nossa proposta. Vale detalhar a dinâmica naquela edição da disciplina que propunha a escolha de um dos três parceiros da Luz: Casa Florescer, Cia. Mungunzá e Faroeste, e, ainda, no Jardim Ângela, o trabalho conduzido por Luís Galeão no Fórum em Defesa da Vida. A proposta era a formação de rede a partir desse exercício da escuta ativa e da mobilização em prol das demandas desses agentes culturais, sociais. Nós nos dividíamos, respectivamente, Zilda, eu, Bairon e Galeão, na condução dos grupos nos endereços dos parceiros supracitados e mantínhamos o endereço do Faroeste como ponto de encontro geral da disciplina.

\section{A DISCIPLINA ATIVISTA NA PRÁTICA}

Os grupos de teatro se viam diante de uma vizinhança mais arredia, que não frequentava as programações, sobretudo os espetáculos, apesar de todos os esforços para que aqueles ambientes funcionassem como parte de um ecossistema de inclusão social. A dispersão dos usuários já produzia seus efeitos no conjunto de quarteirões e contribuía para um clima de abandono e insegurança geral. Na Cia. Mungunzá, alguns atores do grupo também encarnavam o papel de trabalhadores da Luz, parte do grupo sempre esteve diretamente ligada às articulações propostas na região e serviram inúmeras vezes como parceiros estratégicos disponibilizando os recursos do Teatro de Contêiner: know-how técnico de montagem e elétrica, ponto de encontro, parceria na promoção de atividades sociais para os vizinhos em situação de rua, local para depósito de uma sorte de materiais, além de promoverem debates, sediarem festas e atividades de outros coletivos. 
Como grupo mais midiático da rede local e marcado por representar um extrato social dominante: brancos e heterossexuais de classe média, o fantasma de agentes da gentrificação do pedaço vez por outra aparecia quando o tema era a audiência local. O apelo do Teatro de Contêiner, por sua arquitetura contemporânea, colorida, bem implantada num terreno com espaços de convivência, sempre atraiu um perfil jovem de estudantes de classe média, artistas e ativistas, provocando um deslocamento desse público de outros polos culturais para aquele pedaço da Luz, situação que considero positiva como parte do esforço de reintegração da região na vida cultural alternativa e no cotidiano da cidade. Mas o desafio de incluir o entorno nessa mesma pauta artística e não exclusivamente nas práticas filantrópicas sempre se mostrou real.

Para nos tornarmos mais próximos e estender o convite à vizinhança imediata dos cortiços, dos trabalhadores da região, criamos o projeto Manto-bandeira da Luz. Uma ação pontual, mas que na compreensão geral tocava nesse desafio da integração. Em aula, redigimos e depois distribuímos uma carta convite para engajar a participação de um conjunto bem eclético de pessoas e entidades na composição de um trabalho que proporcionasse um certo grau de união e que servisse de oportunidade para apresentar a Cia. Mungunzá como uma vizinha.

A lista incluía: Atende da prefeitura, Bar do Clóvis, comerciantes, moradores em situação de rua, Ocupação Mauá, Pessoal do Faroeste, Hotel Social, Memorial da Resistência, Escola Livre de Música, Casa Florescer, Pastoral local, Cia. Mugunzá de Teatro, moradores do entorno, Sistema Estadual de Bibliotecas.

São Paulo, 10 de agosto de 2018.

Prezado vizinho,

Entendendo que o melhor da vizinhança é o senso comunitário e a proximidade que isso nos propicia, gostaríamos de nos apresentar formalmente. Somos a Cia. Mungunzá de Teatro, um grupo de teatro com mais de uma década de atuação na cidade de São Paulo, sempre comprometidos em promover a integração social e a ocupação do espaço público.

Há pouco mais de um ano, nos instalamos na rua dos Gusmões, com o Teatro de Contêiner Mungunzá. Passado o período de adaptação e construção de um projeto tão diferente, nos sentimos agora prontos para 
buscar um diálogo que promova uma aproximação maior com as instituições e pessoas do nosso entorno.

Independente das prioridades e demandas de cada um que atua na região da Luz, compreendemos que o convite que fazemos assume a ideia de união. Nos propomos a produzir comunitariamente, em parceria com o Coletivo Diversitas/USP, um manto-bandeira - um tecido composto por várias partes em que todos possam responder à seguinte pergunta: o que é a Luz?

Para expressar sua resposta você está recebendo este tecido com uma caneta. Mais tarde uniremos todas as partes para formar o manto-bandeira que será exposto, integrando simbolicamente os sonhos, os desejos e as diferenças da rede dos que estão comprometidos com o bem-estar no território. Sua participação é fundamental.

Cordialmente,

Cia. Mungunzá de Teatro/Coletivo Diversitas/USP

Essa iniciativa teve como propósito recriar um tecido urbano simbólico composto de partes que traduzissem diferentes impressões da Luz, cujo objetivo também era o de reunir, dessa forma, a expressão conjunta de forças antagônicas da política local. Lado a lado: famílias, instituições e as respectivas diferenças culturais, econômicas e políticas. Celebrar a diversidade da Luz. O manto-bandeira foi lançado com um cortejo à luz de velas pelo quarteirão do Teatro de Contêiner e exposto no hall de entrada do espaço. Com ações como essa, íamos circulando, nos sensibilizando, descobrindo e ocupando a rua paulatinamente.

O manto-bandeira proporcionou a concretização da formação de redes que não dependiam da Internet para acontecer. Ao contrário, respondia a uma demanda proposta por Sérgio Bairon de redes físicas, locais, que muitas vezes não se percebiam como recurso até a quebra do isolamento institucional, até a partilha dos sufocos gerais. Redes de vizinhança, territórios de coexistência, eu complementaria.

Uma observação evidencia um outro desafio que ainda experimentávamos, por mais que estivéssemos presentes, já nesse momento, como núcleo da USP: assinamos essa ação como Coletivo Diversitas, estratégia que corroborava nossa ideia de promover o "hackeamento" da Universidade. O objetivo era livrarmo-nos do entrave burocrático que a rotina da Universidade nos impunha, com o trâmite de ações como essa na reunião mensal do Conselho de Pós- 
Graduação (CPG), por tratar-se de atividade formal do Diversitas no território. Entretanto, o dispositivo "Coletivo Diversitas", como articulador da atividade, nos liberava dentro do timing necessário para articular esse tipo de iniciativa como parte da disciplina.

Em paralelo a essas articulações, a contribuição específica de um grupo da graduação chamou nossa atenção. Primeiramente pela mudança abrupta da percepção geral: de um intimidamento pelo desconhecimento daquela realidade, na própria cidade, passaram para uma tomada de consciência, uma abertura e um empenho na investigação que os lançou para aquela vida tão distante da rotina na ECA-USP, no Campus do Butantã. Criaram agendas independentes no território, conversaram com as pessoas em situação de rua e com os técnicos do hotel social. Algumas vezes, fui informado que "os meninos da USP estavam conversando com fulano... estiveram por aqui."

O trabalho final em vídeo intitulado Sonhos da Luz, ${ }^{108}$ com a direção de Daniel Trimer e Ricardo Kuba, com a produção de Cleiton Ferreira/Dentinho e colaboração de Carolina Gaudencio, resultou numa abordagem sensível, capaz de nos devolver aqueles olhares atentos e sem filtro para um tipo de diálogo improvável tempos antes. Uma ação cultural e pedagógica que tocou na opressão diluída e presente nos centros urbanos, como desafio apontado por Paulo Freire. Fruto do diálogo, da provocação e da liberdade de produção e não de um objeto em análise. O vídeo trouxe essa franqueza e a presença de pessoas do território, homens e mulheres nitidamente confiantes na abordagem dos alunos.

Como disse antes, nossa proposta passava por compreender quais eram, naquele momento, os desafios dos parceiros, as duas companhias de teatro e a Casa Florescer. Nessa dinâmica, investíamos na troca, no companheirismo e não apenas na observação. Procurávamos algo mais próximo do que vimos na antissociologia proposta por Viveiros de Castro, que pretende pensar a diferença na horizontalidade. Se as mulheres trans que ocupavam a Florescer experimentavam, e experimentam, uma baixa autoestima pela falta de endereço próprio, pelo medo de serem violentadas e/ou assassinadas na constante violência urbana que frequentemente as fazem vítimas, pudemos atravessar da Luz até a baixa do Bom Retiro, tocando viola em noite de Lua e serenata para que elas nos recebessem na porta da Casa. O grupo inteiro de alunos e professores cantando pelas ruas do centro até que a música ganhasse uma certa harmonia e

${ }^{108}$ Disponível em https://youtu.be/8jpNTE5s3AY. Acesso em: 22 Dez 2020 
proporcionasse uma chegada menos ensaiada, mais experienciada no percurso, aquecidos para retribuir o acolhimento delas, num gesto de carinho e deferência.

Mesmo assim, não havia mágica nessa aproximação, sempre se repetia o começo com o distanciamento social marcante e recorrente: residentes da Florescer de um lado, alunos da USP de outro, muitas falas e pouca interação espontânea. Mas estávamos lá para quebrar o gelo, para fazer esse papel de provocadores, animadores. Numa dessas visitas, o encontro terminou num forró com todos misturados e uma possibilidade de comunicação que não pretendia outra coisa a não ser promover a cultura da paz.

Nossos atos performativos respondiam a um convite do interlocutor. Outra situação que mereceu destaque foi o resultado da escuta coletiva dos alunos que se dedicaram à Cia. Pessoal do Faroeste. $\mathrm{O}$ desafio demandado era o de garantir a permanência no endereço da rua do Triunfo. Diferentemente da gestão coletiva da Cia. Mungunzá, a Cia. Pessoal do Faroeste tem uma gestão centralizada na figura do diretor Paulo Faria. Ele reproduz o modelo mais convencional das companhias teatrais marcadas pela presença de um idealizador, como o Zé Celso e o Teatro Oficina por exemplo. Essa característica garante também a repetição da vulnerabilidade dessa escolha. O desafio do aluguel em contratos comerciais padrão diante do exíguo orçamento captado aos soluços, de acordo com os ciclos de editais com fomento para a classe, que nunca fecham a conta. Relações de trabalho pela via da contratação para prestação de serviços e uma rotina com menor capilaridade de ação frente aos arranjos típicos dos coletivos.

O grupo que escolheu se dedicar prioritariamente ao Faroeste, lidou com a proposta da criação do Instituto Cultural Luz do Faroeste, que foi pensado como estratégia para legitimar a permanência da Companhia na sede, pela via de um novo instrumento jurídico mais adequado para formalizar a vocação do teatro em receber uma série de atividades, ligadas aos direitos humanos e à educação, desenvolvidas pelo próprio Paulo Faria e por parceiros, como o Diversitas, e outros coletivos que lá se abrigaram: a Cultive, Associação de Cannabis e Saúde, e a Ocupação Cultural Jeholu, coletivo da identidade negra e do protagonismo a partir dos terreiros.

Para atender a demanda do Faroeste, contamos com a coordenação de outro dos nossos alunos, o advogado Vinícius de Azevedo. Tal como mencionei nas oficinas de adereços 
conduzidas pela cenógrafa Angela Barbosa, somamos com essa outra abordagem, pela via do direito, mais um exemplo de interdisciplinaridade na produção partilhada do conhecimento. Nessa dinâmica, nosso grupo funcionava como articulador/facilitador desses arranjos. A seguir trecho do relatório de conclusão da disciplina feito pelo próprio Vinícius:

\begin{abstract}
A Companhia Pessoal do Faroeste foi fundada em 1998, com o objetivo de realizar trabalhos artísticos que reflitam momentos históricos da sociedade brasileira, de modo a produzir intervenções que valorizem a cidade, o centro de São Paulo e a relação de pertencimento com essa região. Na Rua do Triunfo, na Boca do Lixo, são construídos os projetos da companhia, que também contribui política e socialmente para a região.

O Diretor/Presidente do Pessoal do Faroeste, Sr. Paulo Faria, expôs aos alunos da disciplina o desejo de transformação da Companhia de Teatro, cuja atuação ultrapassava a intervenção artística, em Instituto Cultural e Social, que melhor refletia os objetivos e as finalidades do Coletivo, bem como contemplava suas demais áreas de atuação, na defesa dos direitos humanos.

Para tanto, seria necessário que alguém habilitado como advogado elaborasse um Estatuto Social, instrumento essencial para constituição de uma associação sem fins lucrativos. É nesse contexto, de ouvir a demanda exteriorizada por alguém do território, que se pautou a atuação do autor deste trabalho.
\end{abstract}

O propósito do Instituto foi exaustivamente pensado e reescrito pelo grupo com uma leitura crítica e troca de ideias permanente. O desejo era o de se tornar o retrato mais fiel e atualizado da Companhia do Pessoal do Faroeste. O texto reflete um conjunto de fatores que ao longo dos anos marcaram o entendimento do fazer teatro naquele contexto cultural, social e urbano no qual a companhia está inserida. O estatuto também serviu como exemplo do que nos propusemos com os encontros que nos permitiram uma troca legítima e profícua com os parceiros da Luz. Vale conhecer o objeto social como resultado desse esforço:

Parágrafo $1^{\circ}$ - O Instituto poderá, para consecução de seu objeto social, utilizar-se de quaisquer meios e atividades permitidos por lei, especialmente: a) promover, apoiar e desenvolver as diversas manifestações intelectuais, culturais, artísticas e literárias por meio de encontros, saraus, oficinas, concursos, estudos, pesquisas, cursos, palestras, gincanas, premiações, desfiles, shows, peças de teatro, criação e alimentação de redes, preparação e divulgação de estudos e relatórios, dentre outras atividades; 
b) promover, apoiar e desenvolver, em seus vários desdobramentos, manifestações intelectuais, culturais, artísticas e literárias por meio de treinamento técnico, desenvolvimento, produção, publicação, edição, própria ou por meio de terceiros, de produtos de natureza técnica, cultural, incluindo produtos de áudio e vídeo, itens diversos de papelaria e quaisquer outros meios de divulgação e comunicação que ajudem a divulgar o objeto social do Instituto;

c) desenvolver e apoiar programas de apoio, defesa e conservação de patrimônio histórico e artístico;

d) desenvolver pesquisas e documentação com a finalidade de preservar a produção e a trajetória do "Pessoal do Faroeste" e de suas atividades;

e) promover, por meio da arte e da cultura, programas de educação para difusão do conhecimento e a conscientização sobre a importância da defesa dos Direitos Humanos e de suas garantias fundamentais;

f) preservar e atualizar a memória histórica e social da região da Luz e adjacências;

g) incentivar a interlocução direcionada ao aprimoramento da compreensão crítica acerca dos problemas contemporâneos vivenciados pelos coletivos sociais e pelas comunidades que habitam/participam na região;

h) executar, contratar ou apoiar programas, projetos e ações no âmbito de seu campo de atuação;

i) promover campanhas de arrecadação de recursos para o Instituto, que poderão se utilizar, inclusive, de prestação de serviços, comercialização e licença de mercadorias;

j) celebrar parcerias, contratos e convênios que se façam necessários, com entes públicos e privados, para a materialização do seu objeto social, especialmente com a Universidade de São Paulo, a fim de desenvolver pesquisas, nos mais diversos campos da ciência e do conhecimento, relacionadas aos seus objetivos;

k) criar e desenvolver "redes" com outras entidades que compartilham objetivos semelhantes, a nível local, nacional e internacional;

1) praticar quaisquer outros atos e atividades lícitas para a consecução de seu objetivo social, mesmo que não estejam previstos neste Estatuto Social, desde que previamente aprovados pela Diretoria ou Conselho Deliberativo, e ratificados pela Assembleia Geral.

O Lugar das redes preservadas, descartas, compartilhadas e expandidas, naquele primeiro semestre de 2018 avançou na direção que Paulo Freire apontou, lá atrás, com a proposta de "fazer da realidade objeto de sua análise crítica, jamais dicotomizada da ação" nos 
inserindo no processo histórico como sujeitos. ${ }^{109} \mathrm{O}$ Diversitas na vizinhança da Luz buscou primeiramente, com a disciplina $O$ Lugar das memórias, preservadas, descartadas, compartilhadas, ir ao encontro dessa proposta, já sabendo inclusive que resgatar a memória não poderia limitar-se a revisitar uma narrativa na linha do tempo, mas tocá-la para reinventá-la.

O que aconteceu a partir de todas essas interações para que essa rede se fortalecesse em boas práticas, criadas juntas como pautas para alguma ação, como desejou Freire, foi essa chance de fazermos do resgate, dessas memórias da Luz, outro salto do tigre em direção ao passado e à potência da montagem. Entretanto, a terceira disciplina criada na sequência, que assumiu o título de O lugar das performances; produção partilhada do conhecimento, foi um desdobramento malsucedido no intento de trazer a performance como condição de funcionamento dessas montagens. Encerramos o primeiro semestre de 2019 frustrados, mas dispostos a absorver as críticas e propor algo totalmente diferente para o segundo semestre do mesmo ano. Percebemos o descompasso entre a articulação que tínhamos construído com os parceiros no território, nas versões anteriores, e a previsível insegurança que alguns docentes, neófitos na disciplina, experimentavam na tentativa de contribuir com a participação no teatro, sem uma proximidade consistente com o território da Luz.

A estratégia que adotamos e que incluiu novos professores tinha a ver com ampliar o convite dentro do Diversitas e engajar outros simpatizantes desse deslocamento das aulas para o centro, numa tentativa de não deixar que a ampla repercussão positiva que começávamos a perceber ficasse concentrada num protagonismo que não nos interessava: o nosso mesmo. Entretanto, o limite concreto de atuação fora do Campus, do formato tradicional da sala de aula, expôs a falta de capacidade para lidar com o improviso e uma distância do ato performativo. Vivemos uma teatralização da aula com um nível de risco e exposição controlado o suficiente para conservar todos os códigos nos seus devidos lugares. Assim, mais próximos da representação da coisa do que do ato em si. Mesmo vivendo essas questões, sustentamos um tipo de encantamento com a proposta no teatro, mas distanciamo-nos da vizinhança e da necessária capacidade de correr riscos.

A quarta e última edição da disciplina, com o mesmo título e uma abordagem bem diferente, resgatou nossa persistência na ocupação da rua. Permitiu-nos ultrapassar a concretude

${ }^{109}$ FREIRE, Paulo. Pedagogia do oprimido. Rio de Janeiro/São Paulo: Paz e Terra, 2019. p. 249. 
das coisas para experimentar outro tipo de inserção: a da sobreposição dos "agoras" que garantiam recriar camadas de cidade e coexistir em eixos espaços-temporais do território da Luz, como síntese das contradições, belezas, descasos e erotismo da cidade de São Paulo. Se as aulas já tinham se caracterizado como encontros, nessa experiência, os encontros se transformaram em cenas. Ali, experimentamos o teatro humano no desafio de criar linhas de fuga, estados de intensidade, no que nos restava de descontinuidade no teatro social para viver o ser-com.

Naquele segundo semestre de 2019, tivemos uma nova parceria com a Princeton University, através da disciplina São Paulo: Cultural and Urban Connections, sob responsabilidade da professora Marília Librandi, do Departamento de Espanhol e Português. Tivemos também uma situação inédita e totalmente descolada das anteriores: a Cia Mungunzá, além de nossa anfitriã, dessa vez, participou na preparação da disciplina como aulas/cenas e atuou lado a lado na condução dos trabalhos. Nosso grupo foi composto da seguinte forma:

Diversitas - Maria Ribeiro, Marcelo Carnevale, Sandra Regina Chaves Nunes e Sérgio Bairon; Princeton University - Marília Librandi; Cia. Mugunzá de Teatro - Lucas Beda, Santiago Cao e Verônica Gentilin. Quem seriam os atores? Quem seriam os alunos? Quem seriam os professores? Quem seriam as pessoas da vizinhança? O que buscávamos como resposta era o interesse na multiplicidade para reformular, vivenciar e compartilhar o conhecimento, estética e socialmente. Os atores seriam todos os presentes. A ideia é que coubesse ao grupo como um todo, sem exceção, um papel ativo em algum acontecimento.

A parceria com a disciplina oferecida por Marília Librandi, em Princeton, permitia-nos repetir a dobradinha com alunos de graduação. A proposta da professora trazia a interdisciplinaridade, com foco na cidade de São Paulo, sua vida cultural, suas complexas interações sociais e sua história urbana, passado e presente, estudada a partir de elementos da literatura, cinema, teatro, artes visuais e arquitetura. Marília acreditava que a participação dos alunos estrangeiros, falantes de português, permitiria uma imersão dialógica que, à distância, aproximaria comparativamente São Paulo-Princeton-New Jersey-Nova York. Passamos o mês de julho nos encontrando para o planejamento das atividades com o empenho e a alegria necessária para a criação das cenas performáticas. 
O trabalho envolveu um planejamento de comunicação capaz de nos liberar das dúvidas mais comuns que costumam tomar os alunos no primeiro encontro. A ideia era explorar as redes sociais e o e-mail como lugar de administração do fluxo dessas informações, ao reforçar esses canais como os meios de difusão do discurso padrão das boas práticas acadêmicas. Assim garantiríamos um entrecruzamento entre o espaço virtual e o espaço presencial com diferentes abordagens. No conjunto, pretendíamos manter os alunos estabilizados remotamente quanto à vida acadêmica e liberados para viverem as cenas, in loco, em tempo real. As redes sociais serviriam para reflexão sobre as cenas, também.

Pretendíamos uma desconstrução geral da dinâmica pedagógica padrão da sala de aula na Universidade. Como se, ao nos libertarmos das regras que pontuam a verificação de performance no sentido mais positivista possível (calendário, critérios de avaliação, burocracia da pós-graduação, regras quanto a presença, verificação distintiva entre matriculados, especiais e ouvintes etc.), estivéssemos disponíveis para viver o teatro com alguns objetivos propostos:

\begin{abstract}
A disciplina tem por objetivo compreender as dimensões dos conflitos e contradições existentes na cidade como palco social. A performance será trabalhada por meio das possibilidades de expressar tanto conceitos teóricos quanto as liminaridades presentes nas possibilidades de produção partilhada do conhecimento. O objetivo central apresenta, de um lado, a necessidade de inserção do corpo no território público da cidade e, de outro lado, a reflexão teórica a respeito dos conflitos sociais presentes no espaço urbano. A elaboração destes conflitos é terapêutica para os sofrimentos sociais produzidos pela negação, material e cultural, do reconhecimento como pessoas daqueles que vivem às margens do poder na sociedade.

O Lugar das Performances é definido como a região da Luz, no centro da cidade de São Paulo e terá seu ponto de encontro no Teatro do Mungunzá. Mais que um espaço físico, o Teatro e a região da Luz serão, por excelência, o lugar das performances, considerando que toda transformação das relações sociais passa pela criação e ocupação de espaços de convivência. ${ }^{110}$
\end{abstract}

Nosso roteiro totalizou dez aulas/encontros/cenas:

${ }^{110}$ Trecho da ementa da disciplina "O lugar das performances; produção partilhada do conhecimento", $2^{\circ}$ semestre de 2019. 
Cena 1. A disciplina ativista. (Res)sensibilização dos corpos e (re)conhecimento do território e suas práticas. Manifesto dos Undercommons

Cena 2. SP Guarani

Cena 3. A cidade líquida

Cena 4. Fluxos e Derivas (situacionistas)

Cena 5. A Escuta e a Escrita da Cidade

Cena 6. Resistências, Ruínas, Existências e Ocupações

Cena 7. O comum e a comunidade: o ser-com da produção partilhada

Cena 8. Afro:Sampa.

Cena 9. Trans-Cidades: Diversidades

Cena 10. A vizinhança

Cena 11. Apresentação dos grupos

Cena 12. Encerramento, apresentação final dos grupos.

Estávamos novamente na terra do talvez. A ultrapassar o estreito, que, segundo Derrida, só é possível nas humanidades, no deslocamento necessário para além da oposição constatativo/performativo. Lugar que somente se alcança fora do contexto, da convenção, do contexto institucional, como pudemos compreender território de coexistência.

\section{BOCADOLIXOCINEMA, NOVOS ATORES}

Com esse conjunto de cenas retomamos mais fortemente a ocupação no território da Luz, reservando para a nossa casa anfitriã a Cia. Mungunzá. Eram produções mais complexas, com a presença recorrente de um grupo de músicos sob o arranjo musical de um dos colaboradores da disciplina, Felipe Chacon. Pudemos contar a ampliação de endereços na rede da Luz: o Centro Cultural Judaico, a Casa do Povo, no Bom Retiro; a Ocupação Mauá, na rua que leva o mesmo nome; a Passarela das Noivas, que atravessa a avenida Prestes Maia na altura da rua das Noivas; a calçada junto à Sala São Paulo, próximo a Praça Júlio Prestes; a calçada do Parque da Luz junto à Pinacoteca do Estado de São Paulo; o saguão da Estação de Trem da Luz; a Casa Florescer e, finalmente, o Bar do Clóvis, em frente a Mungunzá. 
Muitos convidados partilharam as cenas conosco: o coletivo Secura Humana; os Guarani do Jaraguá, com falas de Ana Maria Silva Kariri, Sônia Ara Mirim e Davi Guarani; Silmara, liderança na Ocupação Mauá; a Ocupação Cultural Jeholu, sob a curadoria dos nossos alunos Felipe Brito e Renato Santos, e com falas de Pai Sidnei de Xangô, Ogã Pejigã Rafael Pinto; a atriz trans feminista Leona Jhovs, junto com as mulheres da Casa Florescer e, na cena da vizinhança, Clóvis, dono do bar que nos acolheu para a festa.

A disciplina contou ainda com mestrandos da etnia Bororo, que participaram a partir da Aldeia Meruri, numa parceria que envolveu os professores Aivone de Carvalho, Sérgio Bairon e Marília Librandi, diretamente de Princeton. Mais uma vez conseguíamos uma descentralização, uma horizontalidade, na qual professores colaboradores, atores, músicos, ativistas, alunos e a comunidade em geral participavam na partilha de cada cena.

Destacarei dois momentos que imprimiram a intensidade do convite que fazíamos: a primeira e a última cena. Nossa primeira cena trazia claramente uma montagem teatral. Roteiro decupado, com falas definidas, pontuações musicais, movimentação marcada, ambientação multimídia com projeções e efeitos sonoros, tudo articulado para que o tempo teatral imperasse e pudéssemos assumir a condição de atores em cena. Dessa forma, nosso texto teatralizava a disciplina de maneira radical, sem brechas para que duvidássemos do que estávamos defendendo como proposta a partir do tempo fora do tempo, o tempo da cena. Trabalho de autoria coletiva que tinha como foco questionar a Universidade no amplo e crescente conjunto de protocolos. Naquele momento a Universidade de São Paulo se diluía no estilhaçamento institucional como condição de proximidade. Nunca desejamos outra coisa senão a proximidade com quem quisesse partilhar a partilha.

Paradoxalmente partíamos de uma proposta fechada, naquele primeiro encontro, portanto mais expositiva e performática pela força da proposição, conduzida para promover uma sensibilização geral pela presença naquele corpo coletivo, pelo que podíamos considerar uma tempestade de inquietações. Levávamos a cabo o paradoxo citado antes: a desinstitucionalização do ensino como parte de uma proposta institucional, fosse na meditação ativa conduzida por Verônica Gentilin ou na leitura do manifesto dos Undercommons que deu o tom da disciplina, abaixo apresentado com as marcações e rubricas do roteiro teatral: 


\title{
MANIFESTO DOS UNDERCOMMONS ${ }^{111}$
}

\author{
(leitura: Marilia)
}

Não dá pra ser impessoal quando a dor é na carne

Na pele da palavra

O que vamos dizer é pessoal

porque o caminho não é reto

nem discreto

E porque gente é pra brilhar

não pra morrer de fome

E para brilhar a gente tem de se dizer

De se des-dizer ... continuamente

progressivamente

Saindo de todas as estruturas e entrando nelas

para roubá-las e nos roubar de nós mesmos

"Para ir à universidade eu roubarei, e lá eu roubarei"...

essa é a frase de abertura do texto "A universidade e os undercommons"

O que vocês vão ouvir são trechos escolhidos desse texto de Fred Moten e Stefano Harney, transformados por nós em manifesto dos undercommons... que lançamos hoje nesse curso/cena porque é aqui que nós, undercommons, nos reunimos....

(leitura: Marilia)

Os undercommons ("subcomuns") podem ser traduzidos com o termo "subhumanidade" de que fala Ailton Krenak em Ideias para o fim do mundo: "os únicos núcleos que ainda consideram que precisam ficar agarrados nessa terra são aqueles que ficaram meio esquecidos pelas bordas do planeta, nas margens

${ }^{111}$ Manifesto criado por Marilia Librandi inspirado no livro The undercommons fugitive planning \& black study de Stefano Harney e Fred Moton, publicado em Nova Iorque, em 2013. 
dos rios, nas beiras dos oceanos, na África, Ásia ou na América Latina. São caiçaras, índios, quilombolas, aborígenes - a sub-humanidade."

"Porque tem uma humanidade, vamos dizer, bacana. E tem uma camada mais bruta, rústica, orgânica, uma sub-humanidade, uma gente que fica agarrada na terra. Parece que eles querem comer terra, envoltos na terra. A organicidade dessa gente é uma coisa que incomoda, tanto que as corporações tem criado cada vez mais mecanismos para separar esses filhotes da terra de sua mãe."

Contra essas corporações e a favor dos undercommons e do seu plano de fuga escreve Fred Moten, pensador da negritude, professor do Departamento de Performance da NYU, New York University... um insubmisso, um undercommon... fazendo comum com a gente...

MOTE, DÁ-NOS O MOTE! OUÇAMOS/CANTEMOS/DANCEMOS com as palavras....

\section{ESTÁ FUNDADO O MANIFESTO DOS UNDERCOMMONS}

(leitura: pergunta e resposta)

UNDERCOMMONS, O QUE É?

SUBCOMUM?

SUBTERFÚGIO?

SUBDESENVOLVIDOS?

SUBTERRÁQUEOS?

SUBAQUÁTICOS?

SUB-HUMANOS?

(todos juntos)

INSUBMETIDOS!

(leitura coletiva; cada item será lido por um de nós seguidamente: Sergio, Marilia, Sandra, Maria, Marcelo, Veronica, Lucas, Santiago, Chacon, Debora, Thomaz, Magda, Felipe Brito, Américo, Jaderson, Gisela, Lenilson, Jamille, Jaya) 
1. Para ir à universidade eu roubarei, e lá eu roubarei ...

Esta é a única relação possível com a universidade nos Estados Unidos hoje, mas também em outros lugares;

2. Não se pode negar que a universidade seja um lugar de refúgio; e não se pode aceitar que a universidade seja o lugar de esclarecimento;

3. Abusar da hospitalidade da universidade é desrespeitar sua missão, juntarse às suas colônias de refugiados, ao seu acampamento cigano;

4. ... estar na universidade, mas não ser da universidade - este é o caminho da intelectual subversiva (e dos intelectuais subversivos);

5. Criar a comunidade de fugitivos na universidade, os foragidos do conhecimento, no subcomum: é aí (aqui) que o trabalho é subvertido, que a revolução ainda é negra e índia;

6. Devemos, ao mesmo tempo, reproduzir a universidade e produzir a fuga... rumo a uma orientação coletiva;

7. O objeto do conhecimento é um projeto futuro e um compromisso com o que nós queremos chamar de organização profética;

8. Pela revelação arrebatada... criminosa, matricida, queer que o esclarecimento fugidio encena, uma paixão radical e uma passividade tal que fazem com que a pessoa não possa ser subjugada;

9. Os undercommons formam, portanto, uma vizinhança sempre insegura;

10. O trabalho universitário pode abrigar refugiados, fugitivos, renegados e náufragos. Mas tais elementos serão expostos ou forçados à clandestinidade;

11. E o que dirá a universidade deles? Dirá que eles não são profissionais. ... não são práticos, não são rigorosos, não são produtivos. Isso não é um ataque arbitrário. É um ataque contra os mais que profissionais;

12. Como é que aqueles que excedem a profissão, e que por excederem escapam, como esses fugitivos se problematizam, problematizam a universidade, forçam a universidade a considerá-los um problema, um perigo?

13. Os undercommons estão sempre em guerra, sempre escondidos; 
14. Os fugitivos são a condição de possibilidade da produção de conhecimento na universidade;

15. Esse espaço dos undercommons surge e é sustentado pelo trabalho coletivo;

16. Não basta ser um acadêmico crítico na universidade; o acadêmico crítico é sempre, ao mesmo tempo, uma afirmação do individualismo burguês;

17. Não basta estar contra a universidade;

18. Estar contra a universidade é reconhecê-la e ser reconhecido por ela. E este ato de estar sempre contra exclui os modos não reconhecidos de política, a para-organização criminal desacreditada, o campo infrapolítico (e sua música).

19. A profissionalização... exclui a organização profética dos undercommons, mas os fugitivos recusam-se a recusar a profissionalização, os fugitivos recusam-se a ser contra a universidade;

20. UNDERCOMMON é ser contrainsurgente, é acolher os que estão desacreditados;

21. Ser demasiadamente contra a Universitas cria o perigo de que elementos específicos do estado (bolzominion) tomem medidas para livrar-se da contradição do projeto da Universitas e substituí-lo por alguma outra forma de reprodução social, o antiesclarecimento (nefasto/fascista);

22. Não queremos acabar com a universidade...

Queremos a universidade no centro

No centro do debate

No centro da cidade

No centro do teatro

Teoria em ato

23. Os undercommons estão cansados da crítica e, ao mesmo tempo, estão dedicados à coletividade do seu futuro, à coletividade que pode vir a ser o seu futuro.

Por mais sedutora que seja a crítica, por mais provocada que seja, nós undercommons sabemos que não é amor; 
24. Vamos roubar seus livros numa certa manhã e doá-los a estudantes não inscritos, em um boteco meio caído e com cheiro de cerveja, onde o seminário sobre os esconderijos e os empréstimos acontecem;

25. O trabalho dos não profissionais na universidade causa revolta, retração, liberação... o impulso fugidio de confiar nos undercommons para proteção, e de insistir na honra da comunidade fugidia;

26. Impulso criminoso de roubar das profissões, da universidade, roubar o esclarecimento para outros, roubar a si mesmo com uma música triste, um certo otimismo trágico, para roubar com uma intelectualidade de massa;

27. Talvez então seja preciso dizer que o vendedor de crack, o terrorista e o preso político compartilham um compromisso para com a guerra e que a sociedade responde em espécie com guerras ao crime, ao terror, às drogas, ao comunismo...

28. O slogan na Esquerda, então, "universidades, não prisões," marca uma escolha que pode não ser possível;

29. Talvez mais universidades promovam mais prisões;

30. Talvez seja finalmente necessário ver que a universidade produz encarceramento como o produto da sua negligência;

31. Talvez haja outra relação entre a Universidade e a Prisão - além da mera oposição ou semelhança familiar - que os undercommons reservam como o objeto e a moradia de outro abolicionismo;

32. A universidade não é o oposto de prisão, já que ambas estão envolvidas a seu modo na redução e no comando do indivíduo social....

33.Os undercommons pensam na prisão como um segredo que clama pelo profético;

34. Os undercommons da universidade são um não-lugar de abolição Qual é, por assim dizer, o objeto da abolição?

35. Não tanto a abolição das prisões, mas a abolição de uma sociedade que poderia ter prisões, que poderia ter escravidão, que poderia ter salários e, portanto, não a abolição como a eliminação de qualquer coisa, mas a abolição como a fundação de uma nova sociedade; 
36. O objeto da abolição teria então uma semelhança com o comunismo, que seria, para Spivak, mistérios;

37. O misterioso que perturba a crítica, o misterioso que se pode perceber na profecia, o conteúdo que agrega, de uma cadência, e o misterioso que se pode sentir na cooperação, o segredo que uma vez se chamou solidariedade;

38. O sentimento misterioso que fica em nós é o de que há alguma coisa a mais no undercommons. É a organização profética que trabalha para a abolição vermelha índia e negra!

(FIM)

O que importa desse manifesto é que ele se tornou coletivo e experienciado durante os meses seguintes, na relação do lugar das performances como produção partilhada do conhecimento na Luz. Não mais de forma parcimoniosa e controlada, mas carnavalizado. As derivas/cenas permitiram novamente que fragmentos distantes uns dos outros entrassem em relações inesperadas. O que poderia dar-se nessa linha tênue dos estados alterados de realidade, na cena como resultante da diversidade dos undercommons, subcomuns? Nessa Universidade que tentava se recriar numa outra configuração para sempre com o pensamento de fora, com as bordas que se tocam?

Ao recuar um pouco novamente, posso apelar para a memória como parte do percurso que me fez experimentar a transição do total fastio da palavra Vizinhança para o sentimento de mistério que "perturba a crítica" e que aflora apenas pela experiência, ou ainda com Turner, pela antropologia da experiência, no caso do avizinhar-se.

Nessa contínua escavação palimpséstica em busca de uma literatura menor na Luz, lembro da minha participação na premiação "Cai de boca", que a Cia. do Pessoal do Faroeste criou para homenagear as pessoas que protagonizaram os tempos de glória, bem como novas personalidades da Boca do Lixo. O diretor Paulo Faria me convidou para entregar um dos prêmios a uma das homenageadas. Uma ex-atriz dos tempos áureos da Boca. Durante a cerimônia, ouvi aquele grupo de mulheres relembrando o passado da indústria cinematográfica, o cotidiano do cinema brasileiro acontecendo, ali, na rua do Triunfo. 
As atrizes Vanessa Alves, Nicole Puzzi e Noelle Pine conservavam a sensualidade que lá atrás tinham garantido cenas de cinema. Ali, aguardando a minha vez para entregar o prêmio Cai de Boca, que se tratava de um pé de um scarpin coberto de purpurina, ocorreu-me fazer um agradecimento. Minha fala destoou do tom melancólico, para não dizer tristonho, com o qual as atrizes compartilhavam o estigma de terem atuado em pornochanchadas, nos anos 1970, e o quanto isso limitou a carreira da maioria delas em outros palcos e outras mídias, após o declínio daquele gênero de produção cinematográfica nos anos 1980.

Curiosamente, pouco antes de tomar a palavra, veio em minha mente um fluxo de imagens das películas da Boca que pude assistir na minha infância e, que diante da ingenuidade de menino, guardaram prioritariamente o que aparecia em segundo plano: a cidade de São Paulo. Enquadramentos e fotografias belíssimas da cidade já num patamar de megalópole, lembranças que promoveram minha primeira aproximação com a cidade. Lá estava eu, no mesmo lugar, quase quarenta anos depois para dizer "obrigado" às atrizes e para contar essa história.

Tudo isso tinha a ver com a proposta que desenhei para a disciplina: "Cena 10. A vizinhança". Nessa linha tênue que decidimos cruzar, próxima de um conceito que pretendo explorar em outros projetos, mas que já percebo ser um caminho possível como desdobramento desse trabalho: a ficção crítica, ${ }^{112}$ investi num diálogo com o minidocumentário que é uma crônica audiovisual do cinema da Boca, registrada por um dos seus mais famosos diretores de cinema: Ozualdo Candeias.

Hoje, não mais um menino, já com a idade dos técnicos e "amigos de amigos de amigos" que participaram da festa registrada por Candeias, na mesma Rua do Triunfo, nos idos de 1970, busquei uma superposição de "agoras" que uniria as duas celebrações na rua do Triunfo; a filmada em 31 de dezembro de 1976 e a que faríamos em 8 de novembro de 2019.

$\mathrm{Na}$ "Cena 10. A vizinhança", nós produzimos uma festa tal qual a documentada pelo cineasta da Boca em 1976: "Bocadolixocinema"113. A parceria foi selada com Clóvis, dono do botequim que faz esquina com a Mungunzá. Dentro do estabelecimento, projetamos o filme numa das paredes. Na porta e do lado de fora fizemos a nossa festa. Tivemos a qualidade

\footnotetext{
112 https://en.wikipedia.org/wiki/Fictocriticism

113 Documentário de Ozualdo Candeias, 1976 https://youtu.be/SpQ0SKtVhXI Acesso em 22 Dez. 2020
} 
cenográfica de sempre, que transformou um carrinho de supermercado num palco rodante. Chacon levou os músicos. A nossa festa tinha um mote especialmente pensado para a noite: criamos o prêmio de entrega da chave da vizinhança da Luz. Ela foi concedida a algumas figuras da comunidade envolvidas com a vida no centro. Constava na lista: Casa Florescer; Coletivo Tem Sentimento, Instituto Bixiga, Ocupação Mauá, o cineasta e comerciante local Bruno Ramos, Blocolândia, Bar do Clóvis, a líder comunitária Janaína Xavier, a vizinha ativista Natalina Ribeiro, o mediador do território e integrante da Cia. Mungunzá Luiz Lira. Todos receberam o e-mail convite, como esse especialmente escrito para Carmen Lopes:

Festa de entrega da chave da vizinhança na região da Luz

Prezada Carmen Lopes,

Em nome do Diversitas-USP, temos a honra de convidá-la para a cerimônia de recebimento da chave da vizinhança da região da Luz. A festa acontecerá em frente ao Teatro de Contêiner da Cia. Mungunzá, na rua dos Gusmões, 46, às $20 \mathrm{~h} 30$, no dia 7 de novembro.

Consideramos o seu trabalho no Coletivo Tem Sentimento uma iniciativa importante na capacitação e empreendedorismo social. Uma inspiração.

\section{O Diversitas na Luz}

Diversidade, direitos e outras legitimidades é o conjunto de valores que norteiam a existência do Diversitas, Núcleo de Apoio à Pesquisa da Faculdade de Filosofia, Letras e Ciências Humanas da Universidade de São Paulo.

Esse norte ganhou outro sentido quando resolvemos nos integrar aos esforços de diálogo comunitário na região da Luz.

A universidade fora do Campus permitiu fazer da pesquisa e extensão a referência para criação de uma nova modalidade: a disciplina ativista, nesse semestre, O Lugar das Perfomances: Produção Partilhada do Conhecimento. Proposta que demanda o corpo na cidade e que ao longo dos últimos três anos, em três edições semestrais, reuniu cerca de 180 participantes entre alunos regulares e ouvintes, na experiência da articulação comunitária, da reflexão acadêmica e da produção estético-científica.

$\mathrm{Na}$ Boca do Lixo, ou quadrilátero do pecado, centro velho da cidade e referência da indústria cinematográfica nos anos de 1970, os pesquisadores do 
Diversitas abriram corações e mentes para tecer uma rede local com interlocutores da região. Somos parceiros constantes dos que buscam articulações que possam garantir os direitos e a permanência dos mais vulneráveis a todo tipo de investida que expressa o aniquilamento da integridade humana. Rotina que nos colocou em contato com os desafios de ouvidos destreinados para a violência do sofrimento urbano, tão evidente na região da Cracolândia.

A adesão e presença de vocês contribui diretamente para reafirmar a importância dessa aproximação com a região da Luz que se faz estratégica para a preservação da memória, para a rede de cidadania, para a continuidade de uma política de redução de danos no consumo de álcool e outras drogas, para a justiça social. E, sobretudo, para o entendimento que juntos desejamos e atuamos por uma cidade melhor.

Muito obrigado.

Marcelo Carnevale

Pesquisador Diversitas-USP

Sergio Bairon

Coordenador Diversitas-USP

Como mediadores do evento, eu e a professora Maria Ribeiro fomos adornados com adereços especialmente cedidos por Jogê Pinheiro, que era uma colaboradora trans da Casa Florescer e articulamos a distribuição das chaves de maneira que, prioritariamente, alguém da vizinhança da Luz entregasse a chave para os homenageados. Nessa situação, experimentamos um momento marcante quando chegou a mim o pedido para que uma mulher trans negra entregasse a chave da Vizinhança para Carmen Lopes.

O Coletivo Tem Sentimento criado e coordenado por Carmen foi uma aposta de quem já viu muita coisa no território e conhece de perto a opressão e o sofrimento daquela população. Conheci Carmen quando ela tinha acabado de ser desligada do De Braços Abertos, mas mantinha vestido o colete verde e azul que a identificava como uma trabalhadora da Luz. Reparava, à medida que o tempo passava, como a peça estava desbotada e, junto com esse desgaste, como a incansável figura dessa mulher estava sempre cercada de usuários e pessoas em condições de extrema vulnerabilidade. Foram muitas as atividades de autocuidado promovidas no limite da escassez de recursos, como as várias edições de um jantar romântico 
que ela teve a iniciativa de produzir para prestigiar casais em situação de rua, por conta do dia dos namorados, no Teatro do Faroeste.

Ações importantes como esta, somadas à disposição de Carmen para promover a redução de danos, sustentam com legitimidade o nome do coletivo Tem Sentimento. Ali, diante de todos os participantes, Joh Bintecourt, mulher trans, com a chave da Vizinhança em mãos, pediu a palavra e disse sem rodeios - Carmen, eu devo a minha vida a você.

A ideia de produzir uma festa tal qual a registrada por Ozualdo Candeias era expor essas ocupações e histórias da Boca do Lixo. Como que superpostas, pudessem compor uma vizinhança conectada pelo afeto, naquela esquina tão impregnada da invisibilidade e que pouco tempo antes servira de leito à céu aberto para a população em situação de rua. Naquela altura de 2019, com a mudança do Atende da Prefeitura para outro ponto distante da zona central, a calçada da Mungunzá era monitorada pela GCM, ou seja, desimpedida e pronta para um outro tipo de inscrição na história do lugar.

Essa possibilidade de reescrever e reinscrever-se no território tem a ver com partilhar a palavra achada na rua, tal qual aquela mulher trans fez. E cada vez que ocupamos esse lugar na cidade, estamos ajustados na inteireza dos sentidos do corpo presente.

Como nos propôs Viveiros de Castro, uma antropologia menor repleta de pequenas multiplicidades.

Sublinho: proliferar a multiplicidade. Pois não se trata, como lembrou oportunamente Derrida (2006), de pregar a abolição da fronteira que unesepara "linguagem" e "mundo", "pessoas" e "coisas", "nós" e "eles, "humanos" e "não-humanos" - as facilidades reducionistas e os monismos de bolso estão tão fora de questão quanto as fantasias fusionais -; mas sim de "irreduzir" e "imprecisar" essa fronteira, contorcendo sua linha divisória (suas sucessivas linhas divisórias paralelas) em uma curva infinitamente complexa. Não se trata então de apagar contornos, mas de dobrá-los, adensá-los, enviesálos, irisá-los, fractalizá-los. ${ }^{114}$

Era esse o recado sobre "irreduzir", "imprecisar", que nos foi dado pelo conjunto de pessoas vivas e mortas com as quais partilhávamos aquela cena. A alegria do último dia de dezembro de 1976 somada à emoção daquele novembro de 2019, com todo pessoal do cinema e simpatizantes na comemoração, de quatro décadas atrás, juntos com nós mesmos, os

\footnotetext{
${ }^{114}$ VIVEIROS DE CASTRO, op.cit. p. 28.
} 
momentâneos ocupantes da Boca. Lugar "onde não há palavras", como no título do texto escrito por Daniele De Luigi no livro 100 Fotografias: Juan Rulfo ${ }^{115}$ e que faz uma comparação da escrita do autor mexicano com o "correlato objetivo" teorizado por T. S. Elliot, que observa a narrativa a partir de dados simples e concretos, tal qual: "Carmen, eu devo a minha vida a você".

Rulfo, na sua fantasmagoria literária, apresenta-nos Comala, um vilarejo no qual os mortos continuam a ocupar o lugar. $\mathrm{Na}$ Boca do Lixo não seria diferente, sob certa epifania, estávamos naquela aproximação possível em meio ao apagamento geral da própria história da Boca; insistentes na remontagem dos filmes rasurados da vida recente na região da Luz, sem buscar subdivisões entre "linguagem e mundo", tocando as bordas de tantas situações dissolvidas em prol da insistente reurbanização da área. Essa sim, sem vida nem morte, pura ficção.

${ }^{115}$ RULFO, Juan. 100 fotografias: Juan Rulfo. São Paulo: Cosac Naify, 2010. p. 18. 


\section{Parte 3 - Relações centrais de vizinhança: amizade}




\title{
VI. VIZINHANÇA, AVIZINHAR, (RE)VIZINHAR
}

\begin{abstract}
Mais do que uma razão a priori, convém pôr em ação uma compreensão a posteriori, que se apóie sobre uma descrição rigorosa feita de conivência e de empatia (Einfühlung). Esta última, em particular, é de capital importância, nos faz entrar no próprio coração de nosso objeto de estudo, vibrar com suas emoções, participar de seus afetos, compreender o complexo arabesco dos sentimentos e das interações de que ele está impregnado. ${ }^{116}$
\end{abstract}

Michel Maffesoli

\section{O TERMO ATIVO DA VIZINHANÇA}

A proposta deste trabalho é um convite à ampliação do conceito de vizinhança, a partir da experiência da palavra como um território de coexistência, no qual vizinhança se caracteriza pelo conjunto de relações de (des)semelhança, proximidade e amizade, amplamente exposto na série de situações que contribuíram para pensar sobre o vivido.

Esse convite também se apoia na lógica do Dicionário analógico da língua portuguesa, obra de referência que busca algo parecido com uma vizinhança entre as palavras. Dele extraímos e mimetizamos o conjunto de relações de semelhança, proximidade e amizade para criar um composto derivado capaz de impregnar diferentes arranjos de vizinhança na cidade; como um metaconceito que estende à noção de vizinhança algo além de um conjunto de sentidos, um somatório de ações.

Assim, nesse primeiro item da terceira e última parte da tese, proponho-me a pensar nas palavras que funcionariam como termos ativos de vizinhança: avizinhar, re-vizinhar e (re) vizinhar, como termos arbitrariamente escolhidos para o resgate desse convite vital que tem a ver com coexistir de diferentes maneiras. Pensar em territórios dialógicos, cartografados pelas relações concretas, abstratas, físicas, espirituais, objetivas e subjetivas que formam e atuam no espaço através da escuta da cidade.

${ }^{116}$ MAFFESOLI, Michel. Elogio da razão sensível. Vozes, Petrópolis, 2005. p. 66. 
Essa proposta também se abre em outra direção, vem acompanhada de uma apropriação dos sentidos comuns registrados no Dicionário Houaiss dessas três palavras, o que permite uma múltipla combinação de uso no exercício não totalizante do metaconceito, sempre aberto aos sabores e texturas que o reinventam em cada situação.

Vizinhança, o substantivo feminino que indica a qualidade ou estado de estar próximo de algo ou de alguém; proximidade; por metonímia, região localizada perto ou ao redor de um local; arredor, cercania, imediação; vizindade; conjunto das pessoas que moram próximo a alguém; por extensão de sentido, o conjunto das relações estabelecidas entre pessoas vizinhas; comportamento de vizinhos; no sentido figurado, relação de semelhança entre seres, coisas, ideias, analogia; topologia, subconjunto aberto de um espaço topológico que contém um ponto ou um conjunto.

Temos em avizinhar o verbo transitivo direto, bitransitivo e pronominal (preposição com, de), fazer ficar ou ficar próximo; achegar-se, aproximar-se; pronominal, reflexivo e/ou recíproco (preposição de), ir para perto de, acercar-se; transitivo direto, confinar com, ser vizinho de; pronominal (preposição de), ter semelhança; assemelhar-se.

E, finalmente, vizinhar, o verbo transitivo direto e transitivo indireto (preposição com), ser vizinho de; intransitivo, manter convivência de vizinho; transitivo direto e indireto (preposição com), ser limítrofe ou contíguo a; confinar; transitivo direto e pronominal (preposição a e de), aproximar-se, de avizinhar-se; intransitivo na Amazônia, dividir alimentos com os amigos e transitivo direto antigo, habitar próximo de.

Minha hipótese é a de que na aproximação do avizinhar com o vizinhar - o primeiro verbo mais cordial, o segundo mais persuasivo - compreendemos vizinhança como uma síntese disjuntiva que proporciona proximidade pela (des)semelhança, sempre como um evento inacabado. E trata-se dessa imprecisão, irredução, no que se é capaz de apreender e expressar sobre o inacabado, o que podemos perceber como o termo ativo que caracteriza o movimento sutil de avizinhar/vizinhar no coração da palavra vizinhança.

Mas se buscarmos ainda um grau maior de vizinhar, como um termo ativo de avizinharse na vizinhança, o que nos interessa é a produção de sentidos como um sopro forte sem enrijecer o termo já existente, para que vizinhar funcione como elemento indutor da aproximação das descontinuidades dos sujeitos com a continuidade do de fora, e, por assim 
dizer, da partilha gentil da comunidade pelo que é comum a todos e onde não cabe nenhuma imanência.

A possibilidade de conquistar essa fluidez se sustenta somente na pequena multiplicidade, na qual seremos sempre menor que o uno totalizante e potencialmente abertos à diversidade de composições, de vizinhanças com humanos e não humanos, com os diferentes momentos da história na linha do tempo, no qual o avizinhar-se se desdobra como uma constatação afetiva do movimento de vizinhar uma vizinhança. É o que traz a ação liberada do positivismo e da identidade como condição. Traz a qualidade desse presente que concentra uma sucessão de agoras no tempo estilhaçado. Promove um embaralhamento da norma, faz brotar a língua viva na criação de palavras como territórios que se formam nesse avizinhar de quem ou do que está disposto à interação. Faz a língua estalar os dentes e o rosto abrir um sorriso em algum momento.

\section{Re-vizinhar}

Por não ter uma direção única, mas uma (in)tensão no sentido de força, veemência, pode-se introduzir a repetição da ação como condição de permanência do vizinhar na vizinhança. Inacabado, inconcluso, e como nos alerta Nancy, “O inacabamento é seu princípio - mas no sentido onde seria preciso apreender o inacabável como um termo ativo"117 demanda o acercar-se, repetidas vezes mesmo que essa repetição indique diferença e seja aleatória sem nenhum sentido exclusivamente retroativo.

A repetição do vizinhar leva-nos ao re-vizinhar como o convite para uma existência partilhada por aproximação e desejo de permanência mesmo na diferença. Re-vizinhar como aproximar-se de, repetidas vezes; ir para perto de, repetidas vezes; acercar-se, repetidas vezes. Como reiteração de um ato. Um ato político.

Entretanto re-, de origem latina que significa repetição (Rocha Lima, 1996), ao se conectar com vizinhar, permite-nos pensar em outra possibilidade. O linguista e filólogo Alexandre Boechat de Medeiros cogita que o prefixo re-, para além de repetição, pode ser o que a literatura chama de restitutiva, quando a ideia é prefixar verbos que denotam atividades,

\footnotetext{
${ }^{117}$ NANCY, Jean-Luc, op. cit. p. 68.
} 
mas cujo significado não se inclui um estado atingido. ${ }^{118}$ Seria o caso de re-vizinhar nessa formulação, elemento catalizador da ação de vizinhar a vizinhança como simples repetição da ação, num gesto sub-reptício de estar na cidade. Como exemplo, gosto do nome da mais antiga ocupação urbana no Recife, chamada Brasília Teimosa.

\section{(Re)vizinhar}

Dentro do mesmo sintagma temos uma variação metafísica que oscila das dobras do tempo em Re- para a produção de arranjos finitos ilimitados de vizinhança, a partir do elemento (Re) Rênio. Elemento de número atômico 75, localizado no sexto período da tabela periódica, no grupo 7, abaixo do manganês e do tecnécio. (Re) Rênio é metal de transição com propriedades catalisadoras que, em química, caracteriza uma substância que altera a velocidade de uma reação sem ser consumida, durante o processo.

A soma do "elemento $(\mathrm{Re})$ " com o verbo "vizinhar" expressa a vocação de (Re)vizinhar para aproximar uma vizinhança na potência do que se tece a partir da ação em si, ação de acercar-se, apropriar-se como movimento de expansão, atração, mas sem eliminar características anteriores e sim a partir da reação que o desdobramento da transição promove para além das partes separadas. Uma ação inclusiva, como diria Deleuze.

Reação para que a duração no ser-com se articule na transição dos elementos sem perdas totalitárias ou fusões idealistas. Necessário compreender reação no contexto da química como fenômeno que se produz entre duas substâncias químicas postas em contato, com quebra e formação de suas ligações, dando origem a novas substâncias e compostos. Nesse caso, novas vizinhanças.

Rênio, como (Re)vizinhar, também expressa uma transição que se dá como elemento catalizador que age numa composição sem ser consumido pela reação durante o processo. Uma vizinhança atômica que se faz imperceptível, mas que está presente. Conexão parcial com outros mundos possíveis. A coexistência pela proliferação da multiplicidade como faz pensar Viveiros de Castro.

${ }^{118}$ MEDEIROS, Alexandre Boechat de. "Considerações sobre o prefixo RE" (UFRJ-Departamento de Linguística e Filologia; Rio de Janeiro, RJ; 21941-901) in Alfa, v. 56, n. 2, São Paulo, 2010. p. 583-610. 


\section{CONEXÕES PARCIAIS DE VIZINHANÇA}

$\boldsymbol{R e}$-vizinhar como um tipo de retorno que não se repete, uma insistência potente, e (re)vizinhar pela propriedade característica do Rênio, em sintonia com a necessidade que Donna Haraway reafirma de "relearn how to conjugate worlds with partial-connections and not universals and particulars", ${ }^{119}$ faz do prefixo de origem latina e do elemento químico associados ao verbo vizinhar uma associação múltipla tal qual $S F$, o signo criado pela bióloga e filósofa americana: "SF is a sign for Science fiction, speculative feminism, Science fantasy, speculative fabulation, science fact, and also, string figures". ${ }^{20}$

Na grandiloquência paulistana, na cidade murada de prédios, sem horizonte, mais do que em outras cidades, a companhia dos microrganismos que vagam e viajam no tempo pode ser a reinvenção dessa "tarefa infinita (a comunidade) no meio da finitude" da qual fala Nancy. Tanto a propriedade de repetir na diferença, em Re-, com um embaralhamento de tempos capaz de nos colocar no filme da festa da Boca; $(\mathrm{Re})$ como a alteração da velocidade de uma reação sem ser consumido por ela, como viver uma pescaria na festa junina do fluxo, também aparece na bioquímica e designa a função vital das enzimas como cumpridoras dessa função.

Todos os organismos vivos dependem desses catalizadores como pequenas quantidades de uma origem externa que poderiam afetar grandemente o curso de reações químicas. É esta força misteriosa atribuída à substância catalítica. O local da enzima onde o substrato se "encaixa" é denominado sítio ativo ou centro ativo. Consequentemente, o tipo de enzimas encontradas no sítio de uma célula determina o tipo de metabolismo que a célula efetua, como o conjunto de transformações que as substâncias químicas sofrem no interior dos organismos vivos.

As enzimas têm função de aumentar a velocidade das reações sem elevar a temperatura. Isso ocorre porque elas diminuem a energia de ativação necessária para a ocorrência da reação. Por isso, elas são chamadas

119 Minha tradução livre: "reaprender como conjugar mundos com ligações parciais e não universais e particulares". HARAWAY, Donna Jeanne. Stay with the trouble. Duham and London. Duke University Press, 2016, p. 13.

${ }^{120}$ Minha tradução livre: "SF é um sinal de ficção científica, feminismo especulativo, fantasia científica, fabulação especulativa, fato científico, e também, figuras tentaculares.” Idem, p. 10. 
catalisadores biológicos. Se não fossem as enzimas, diversas reações do nosso metabolismo aconteceriam de maneira exageradamente lenta, o que prejudicaria e muito nosso sistema. ${ }^{121}$

Os catalisadores têm sido utilizados pelo ser humano por mais de 2 mil anos. Os principais usos foram a produção do vinho, queijo e pão. Descobriu-se que era sempre necessário adicionar uma pequena quantidade da batelada anterior para fazer a nova batelada. Repetidas vezes como reiteração de um ato.

(Re)vizinhar a partir dessa composição com o rênio (Re) expressa essa qualidade como elemento de transição de engendrar continuidade na descontinuidade para se constituir como movimento de re-vizinhar, e dessa forma tocar no que é comum e coexiste num movimento de impermanência como reiteração do ato: o cinema, a prostituição, a presença dos artistas, o desejo de rua. Uma repetição que se vale da potência de ir para perto, provocar aproximação como algo não totalizante e, portanto, sem possibilidade de reivindicar um símbolo, identidade ou continuidade, mas estabelecendo uma comunicação à medida que sua presença altera a velocidade de uma reação sem ser consumido, durante o processo, mas por contágio.

Essa situação faz do espaço de coexistência o território que propicia um conjunto de transformações no interior de organismos vivos à medida que é possível algum nível de relacionamento para, complementando com a ajuda de Viveiros de Castro, "aceitar a oportunidade e a relevância desta tarefa de 'penser autrement' (Foucault) o pensamento - de pensar outramente", pensar outra mente, pensar com outras mentes - é comprometer-se com o projeto de elaboração de uma teoria antropológica da imaginação conceitual sensível à criatividade e reflexividade inerentes à vida do todo coletivo, humano e não-humano."122

Fazer pão, queijo e vinho é exercitar a hospitalidade que nos interessa, no fazer que nos insere no ritual da partilha, tal qual criar uma disciplina ativista na Universidade de São Paulo para re-vizinhar do centro da cidade e (re)vizinhar dos alunos e, de nós mesmos, com as pessoas, prédios, filmes, memórias da Luz. A aproximação pela ação inclusiva do tempo, químico e

\footnotetext{
${ }^{121}$ Disponível em: https://www.estudopratico.com.br/enzimas-funcoes-e-classificacao/. Acesso em: 22 Dez. 2020. 122 VIVEIROS DE CASTRO, op. cit. p. 25.
} 
orgânico, com toda a sorte de companhia se dá para ativar um sítio e promover a refazenda. Refazendo tudo, como escreveu e canta Gilberto Gil. 


\section{ANCESTRALIDADE COMO AMIZADE}

$\boldsymbol{R e}$-vizinhar como possibilidade de recuar, diminuir de intensidade, para promover uma desordem da cronologia dos fatos e, dessa forma, (re)vinzinhar na (des)semelhança, na aproximação pelo afeto. Enxergo na refazenda o ciclo de renovação pela amizade, bem expresso na ancestralidade como um tipo de vizinhança que sempre evoquei nas apresentações dos participantes das rodas comunitárias, no início dos encontros das nossas disciplinas na Luz.

Dentre as palavras estilhaçadas no presente, proponho recuarmos para brincar com a diferença entre a grafia de atavismo e a de ativismo, no jogo mesmo de substituir o segundo "A" de atavismo pelo primeiro "I" de ativismo, ou vice-versa, para sentir as diferenças que se apresentam na sutileza dessas composições. E pelo deslocamento de mundos promovido pela troca das letras, olhar com a dança dos olhos as peças desse quebra-cabeça, no limite de algo que sinaliza um contexto, ou, ao contrário, de algo que persiste no caos.

Atavismo como reaparição, como re-vizinhar pelos caracteres latentes que tecem de maneira não linear uma conexão parcial, uma aliança com a ancestralidade. Ativismo como transformação, como (Re)vizinhar pela potência dessa ancestralidade da atração, da ação inclusiva.

Nesse entendimento do jogo, convido a pegarmos carona no olhar de uma criança, capaz de apreender todas as possibilidades dessa cena sem querer inscrevê-la em códigos, como se sua visão amplificada a colocasse nesse entre mundos e pudesse fazê-la transitar experimentando a delícia de um balanço entre o "A" e o "I" de atavismo e ativismo.

O que ela escuta? O que ela vê? O que ela sente? De quem ela fica amiga? Por que encontra conforto ao inventar a sua própria língua diminuta, sua própria melodia? E por que, sem se dar conta, os ponteiros do relógio desfazem a lógica do sentido horário e a embalam numa hospitalidade ancestral?

Hoje, 3 de maio de 2018, finalmente instalo-me no prédio colado ao Teatro de Contêiner, na rua do Gusmões, região da Luz, centro de São Paulo. Ele é uma ruína, quase um esqueleto de concreto. Ainda conserva a cor da fachada amarelo queimado e algumas janelas de madeira com venezianas estreitas pintadas de ocre. De dentro, no hall sem guarda-corpo 
composto por ladrilhos hidráulicos intactos, estou sentado à mesa, em perspectiva para o pátio interno. A luz que rebate da fachada é quente e vibrante. Esvaziado pela polícia, ainda guarda inscrições nas paredes de uma ocupação popular na luta por moradia: "2A", "2B", "1-2", "Fuja!!!".

Suas portas estão concretadas, os acessos desapareceram sob tijolos brutos e cinzas, deixou de ser um endereço, caiu na invisibilidade. Entretanto, mesmo anulado, tem memória, tem beleza e permanece como uma caixa de ressonância capaz de absorver os sons do pedaço: hélices de helicóptero, buzinas de carro, o piano do teatro, freios de ônibus, carros, motos, o arrulho dos pombos e os sons da minha cabeça.

Cá estou dentro do esqueleto do prédio. Coloco meu corpo numa laje sem guarda-corpo. Diante do pó, dos escombros e das ruínas, sinto-me como um verme que escarafuncha as brechas de um cadáver. De dentro para fora, sem visão do todo, sem interesse em perspectivas, sem adoração pelas formas, sem querer nada além do micro e desse pó que sopra, como resquício de uma tempestade que fez desaparecer quem por aqui passou, com seus sonhos e desejos de habitar este sítio.

Desde jovem, olho em volta e penso que os prédios terão uma sobrevida bem maior do que a minha. Aqui, experimento o dique que enfrenta a fúria da maré neoliberal, uma correnteza da especulação imobiliária forte o suficiente para eliminar qualquer barreira na região da Luz. Traiçoeira, essa correnteza não é aparente. Apaga pessoas e lugares sem deixar evidências, transforma corpos e coisas em ruínas, sem nenhum tipo de diferenciação.

O tempo da duração promete ser breve. Desse lugar fadado ao desaparecimento e ao esquecimento, evoco um tipo de aliança com a invisibilidade, empresto meu corpo ao prédio sem guarda, numa mediação entre memórias afetivas e fatos recentes, corpo-prédio em desordem, somos toda a cidade e todos os seus sons.

As aproximações são lentas e não fantasio nenhum tipo de aliança. Sinto os dentes numa nevralgia que aponta para a movimentação das raízes em minha boca. Não se trata de amalgamar-se à miséria, mas de moldar-se ao imperfeito humano como condição de troca. Diferentemente da medicina ou da assistência social, o ofício da escrita não me permite nenhum tipo de cuidado direto do tipo causa e efeito. Resta a palavra como território de coexistência e o avizinhar-se com honestidade a partir da escuta. 
As lajes sustentam-se, mas as escadas vão desmanchando-se à medida que os andares ficam mais altos. Tento subir, mas os degraus estão com os mármores soltos e, mais acima, totalmente desconfigurados, servem de anteparo para cacos de tijolos que estacionaram depois de rolarem dos andares superiores. Não existe uma resposta para os porquês. Resta-me a permanência no dentro, no intermediário; não existe acesso ao topo, convivo com o inacessível ao todo.

Meu avô era um prédio em ruínas. Viúvo solitário, contava com a caridade do genro, meu pai, para a visita dominical com os suprimentos da semana. Incluído nessa empreitada, eu acompanhava a rotina das manhãs de domingo na rua Marapanim, uma travessa sem saída no bairro de Benfica, na zona central do Rio de Janeiro.

A cena era sempre a mesma: um homem muito branco de olhar grave, magro a ponto de ter quase todas as suas veias em relevo, sem reboco, num azul espesso e escuro. Vestido em farrapos, com a calça comprida a exalar um cheiro forte de mijo e chinelos calçando pés muito sujos com unhas enormes. Da sua garganta saia um chiado português, andava com vagar.

Eu o achava elegante, a despeito da tormenta que o tinha abatido e de um tipo de embotamento que o fazia inacessível. A ruína estava dentro dele. O quarto do casal mantinha intacta a cena da morte da minha avó: cama desfeita, vestidos no guarda-roupa, objetos de uso pessoal na mesma posição como se garantisse o enquadramento e a suspensão da ação.

Ao meu pai cabia uma generosidade tão discreta que só eu presenciava junto ao meu avô. Limpava os vasilhames dispostos sobre a mesa, enfrentava o bolor e odor da comida, o combate aos ratos, o cheiro de mijo, sempre com uma resignação delicada que o impedia de ser impaciente ou agressivo na condição de cuidador de um velho imigrante ensimesmado e à revelia do tempo.

A casa em estilo art déco era um exemplar padrão daquela rua. Tinha uma pequena varanda que dava acesso à sala, depois uma saleta onde morava uma cristaleira repleta de taças coloridas e, adiante, uma cozinha em L com piso de ladrilho hidráulico e uma generosa janela basculante de ferro e vidro pela qual víamos uma mangueira no quintal. Lá, nos fundos, ficava a oficina do Joaquim, o exímio marceneiro português.

Meu avô não me abraçava, nem me pegava no colo. Estava lá como um náufrago, um sobrevivente, mas eu o via de perto. Um tipo de cumplicidade atávica, eu muito recém-chegado 
acolhia o desencanto, a melancolia, o desinteresse, a depressão, o autoexílio e, também, o livre arbítrio. Esse era o banquete da família. Não existia hipocrisia, muito menos ressentimento na negação que ele expressava ao que lhe era ofertado. Existia um abismo do tamanho de um oceano, uma resolução de negar-se às ações. Uma mesa de vários lugares sempre vazios que se transformava num aparador para o banquete da solidão. Iguarias que esquecidas no cotidiano registravam o dissabor das horas.

Esses dois homens, meu avô materno e meu pai, cada um a seu modo, propiciaram-me esse encontro: daquele que não demonstrava nenhum interesse com aquele que não cobrava nenhum tipo de resposta. Compomos essa família de homens sem respostas.

Joaquim não me contou histórias, muito menos a própria jornada de vida que o trouxe do balneário de Matosinhos, na cidade do Porto, ao norte de Portugal, para o Rio de Janeiro. Nada pude saber além do que se apresentava inconteste diante de mim: ele, como uma vaga lembrança de si mesmo, arrastando os pés para locomover-se ou inerte no sofá. Um silêncio que não me concedeu nenhuma chance de optar por outro caminho a não ser o de recriar a história dele sem certezas, a partir do que eu vi e senti.

No espetáculo Epidemia Prata, que a Cia. Mungunzá apresentou, no Teatro de Contêiner, no mês de julho de 2018, em São Paulo, uma cena fez o elo entre esse portuense e os homens invisíveis que circulam pela área de consumo de crack retratados na performance. Um ator atravessava o palco em cima de um quadrado de madeira sobre rodas e gritava: "somente o mar, sem porto para atracar; somente o mar, sem porto para atracar; somente o mar, sem porto para atracar..." A voz ressoava num lirismo, funcionava como um fio que perpassava o plano natural do tempo e me enredava numa trama sutil que comecei a tecer lá longe naqueles domingos nos quais a solidão do vovô não lhe devolvia o Porto para atracar.

O Rio de Janeiro, final dos anos 1970, abraçava essa rotina domingueira num silêncio típico de uma área pouco residencial próximo à rua Prefeito Olímpio de Melo, uma importante artéria que liga a Avenida Brasil, um dos principais acessos à cidade, à antiga CADEG (Central de Abastecimento do Estado da Guanabara), hoje, denominado Mercado Municipal do Rio de Janeiro.

A pequena travessa sem saída, na qual meu avô morava, era estritamente composta de casas, mas cercada de galpões e carretas estacionadas nas ruas do entorno. Um tipo de 
composição industrial urbana no qual predominava a presença de materiais austeros nas fachadas, revestimento de pó de pedra, esquadrias de ferro, muros de concreto.

Ali moravam velhos portugueses pela proximidade com o bairro imperial de São Cristóvão e com o Estádio de São de Januário, sede do Clube de Regatas Vasco da Gama. Longe das praias oceânicas, próximo da baía da Guanabara, o estranho bairro de Benfica fíca num meio do caminho entre o cartão postal da zona sul e a vida intensa do subúrbio carioca. Árido, decadente, inóspito, parca lembrança de uma época na qual a região era um próspero bairro proletário.

O domingo sem graça cabia no marasmo daquele quarteirão, na solidão do único botequim aberto, sem força para oferecer qualquer novidade capaz de fazer frente à transferência da capital para Brasília, em 1960, ao golpe militar em 1964, ao endurecimento da ditadura, em 1968, a campanha por uma anistia ampla geral e irrestrita, em 1979. Período tão nebuloso quanto a vitrine opaca do boteco, incapaz de conter um tempero de alegria e, mesmo assim, eu pequeno divertia-me visitando aquele lugar.

Talvez tenha sido um dos primeiros percursos que fiz a pé sozinho na recém conquistada autonomia de criança, o que fez da casa do Joaquim o meu porto. Anos mais tarde, assim como o prédio da rua dos Gusmões, meu avô também foi interditado. Morreu internado num asilo público para idosos. Assim como, agora, nesse edifício esvaziado, eu também me instalei na casa dele com a pretensão de encontrar alguma pista sobre o acolhimento nas ruínas.

A casa estava sempre repleta de odores, imperava o cheiro do silêncio encardido que tratava de transformar o não dito em matéria. A mobília e tudo o que ela pôde expressar na filigrana das horas em que um homem se apoiou para sustentar seu estado de vigília. Uma marcação do tempo num longo período no qual a matéria se decompôs antes do seu fim. Joaquim resistiu ereto, calado, tenso, à espreita do último resultado da aposta na travessia atlântica, na teimosia de viver seu Portugal ali mesmo em Benfica. Resistiu como se o último trago fosse beber a si mesmo - a última dose de vida.

Joaquim tomava coca-cola quente para resgatar a ardência da cachaça, mantinha seu cachimbo sempre operante e a brasa lhe devolvia alguma espécie de conforto imaterial. Nela seus olhos se fixavam em consonância com o tempo da duração, para logo em seguida o devolverem ao autoisolamento num ponto qualquer. 
Vez por outra me olhava. Ele tinha a solidariedade companheira dos móveis da casa que eram escuros, sólidos e impregnados pelo perfume do tabaco. Ali estavam suas principais realizações como marceneiro, sua história, seus adornos, acabamentos, frestas, encaixes sem pregos ou parafusos, o brilho resistente. Tudo que me impedia de vê-lo débil, decrépito, claudicante. Era meu avô imóvel e incrivelmente sedutor aos olhos de um neto temporão.

Quase nunca falava comigo, mas prefiro acreditar que sabia que eu era seu neto caçula, de um total de oito netos com uma diferença de idade de vinte e três anos, entre o primeiro entre os primos homens e médicos e eu no outro extremo, criança. Quando eu entrava no seu raio de visão, costumava enrolar um dinheiro e botava no bolso da minha camisa ou me estendia a mão, com um olhar feérico, e me passava a corrente de eletricidade de uma tomada qualquer para me dar um choque. Eu não gostava daquela brincadeira, é claro, mas não me sentia traído. Hoje, compreendo que determinava com aquele gesto e sorriso irônico um tipo de desafio, de aliança, que demorei muito a entender como um convite.

A abordagem do vô Joaquim destoava muito do outro lado do sentimento lusitano que nos unia: o pragmatismo ressentido da sua filha. Fui educado por ela para me afastar ao máximo do perigo de naufragar como o portuense. Minha mãe urdiu um enredo que soterrava a figura do próprio pai na brutalidade e egoísmo a que ele, segundo ela, submeteu toda a família.

Atravessei a escuta dessa narrativa por cada detalhe das violências que aquela filha sofreu; sob uma chuva de recomendações para nunca beber igual a ele, não me meter em confusões, tomar cuidado com a maldade dos outros, não deixar ninguém se aproveitar de mim, não cair em conversa de estranhos, duvidar de quem não conheço e sobretudo: ser determinado, ter um projeto ambicioso e acreditar que querer é poder.

Mas lá atrás houve o choque elétrico e a brasa do cachimbo, o cheiro de madeira de lei do avô imóvel, a fragilidade daquela figura de veias saltadas e olhar grave. Minha participação nessa composição familiar devolveu-me para a diáspora dos enjeitados, na qual aquele velho português já me mostrava que não existia porto para atracar.

O que ficou tem a ver com o que escapou do retrato dessa família. Joaquim permaneceu dia após dia na casa da rua Marapanim, como se tivesse desistido de piscar os olhos. Visão dilatada a criar seu mundo, num estado alterado de realidade. Carregou consigo, enquanto esteve só e retirado na casa, o desentendimento familiar, a mágoa das filhas, a indiferença do 
filho médico, o suor e a sujeira no corpo e a brasa do cachimbo. Tudo isso não nos impediu de fazer uma aliança entre avô e neto, vasos comunicantes que se atualizaram quando reconheci, na minha condição de pesquisador na Luz, o repertório familiar e a possibilidade de agir, colaborar, em prol da inclusão social, por um certo tipo de amizade ao portuense.

Essas ressonâncias familiares vez por outra eclodem em quem atua no território e/ou atua no trabalho da escuta e do acolhimento de qualquer tipo de vulnerabilidade, como um resgate de comunhões perdidas. Existe uma abertura, uma chance de agir que comunica o que Nancy considera a experiência moderna de comunidade. Temos a possibilidade de promover uma atualização ao trocarmos o "A" de atavismo pelo "I" de ativismo, e, pela via do afeto, revizinhar no espaço mesmo, no "espaçamento da experiência do fora, do fora de si". ${ }^{123}$

\section{AVIZINHAMENTOS EXTREMOS}

Convidaria para a mesa da cozinha do vô Joaquim a avenida Suburbana. Hoje, ela se chama Don Hélder Câmara e antes se chamava Estrada Real de Santa Cruz, ${ }^{124}$ importante artéria capaz de fazer circular um Rio de Janeiro por sob uma topografia de morros ocupados e ruas áridas. A avenida Suburbana é parte da família pela cartografia afetiva e através dessa espinha dorsal do subúrbio carioca, ganhei o status de transeunte, pude conquistar a cidade e aprender a deslocar-me. Avenida que comunicava a casa do meu avô, em Benfica, com a minha casa na Abolição. Ele na região imperial do centro, nós no subúrbio da Zona Norte carioca, que é conhecido como Grande Meier, mais próximo de Madureira. Na avenida Suburbana estava exposto boa parte do desleixo no qual o Rio de Janeiro se configurou no período pós-colonial, sobretudo a partir do improviso na articulação da vida dos descendentes de escravos nos rincões da produção de café e açúcar daquela região do Engenho de Dentro, que se tornou um bairro

\footnotetext{
${ }^{123}$ NANCY, Jean-Luc, op. cit. p. 48.

124 Originalmente fazia parte do https://pt.wikipedia.org/wiki/Caminho_ImperialReal de Santa Cruz e Estrada Imperial de Santa Cruz, que ligava o Município da Corte a Sepetiba, passando pela entrada da Fazenda Imperial de Santa Cruz. Disponível em: https://pt.wikipedia.org/wiki/Avenida_Dom_Hélder_Câmara Acesso em: 22 Dez. 2020.
} 
importante, no século XIX, por abrigar as oficinas da Central e a estação ferroviária distribuidora de vários ramais, hoje, Estação Olímpica do Engenho de Dentro.

Vivíamos em casas simples, nas ladeiras sob sol a pino, em vilas, becos e favelas, que, eram ocupadas respectivamente por pequenos comerciantes portugueses, italianos do sul, seus filhos, netos; nas moradias mais pobres e nas favelas estava a concentração da grande maioria dos afrodescendentes. Longe do mar, com quarenta e dois graus no alto verão, essa convivência era intensa e, mesmo com as discriminações raciais veladas, o clima era de relações cordiais. Experimentávamos uma aproximação e uma rica troca das culturas que compunham o relicário da vida carioca suburbana com a inevitável miscigenação, o samba e o típico comércio de rua dos imigrantes, com seus balcões que funcionavam como ponto de encontro dos moradores.

$\mathrm{Na}$ nossa família, como parte inconteste do sincretismo religioso e da vida cotidiana do subúrbio, tínhamos lugar para a irmandade dos pretos velhos na presença espiritual de uma preta velha que nos aconselhava toda semana, vovó Chiquinha de Aruanda. Entidade que a filha mais velha de Joaquim recebia no terreiro da própria casa, em Higienópolis, bairro também localizado ao longo da av. Suburbana. Teresinha de nascença, Teresoca como a chamava o português, Tia Zoca como a chamei por toda a vida. Mulher que me deu um outro entendimento de aliança, de filiação, de vizinhança, ao entoar seu canto:

Quem vem, Quem vem lá de tão longe, são nossos guias que vêm trabalhar, oh dai-me forças, dai-me forças, pelo amor de Deus meu Pai, oh dai-me forças aos trabalhos meus.

Tia Zoca, com seu quarto dos santos ao pé de uma goiabeira, matinha seu terreiro num cômodo no terceiro platô de um terreno escarpado. Era o ponto mais alto da casa suburbana, com um pátio no qual organizávamos os bancos de madeira para que os vizinhos aguardassem as consultas com o guia. O quarto imenso possuía uma janela para esse pátio, como uma casinha que se abria no início da noite. Revelava seu piso coberto de areia fina e branca do mar, luzes azuis e muitas orações que conduziam o transe, sustentado pelo canto coletivo. Ela sempre vestida de organza e rendas brancas, com um lenço branco amarrado na cabeça. Ao ceder lugar para a preta velha no seu próprio corpo, expressava a presença da entidade ao 
revirar um dos seus olhos para caracterizar a marca do açoite no trabalho escravo, que vovó Chiquinha carregava consigo. Com a sua chegada, cantávamos:

Vovó Chiquinha quando chega de Aruanda, cruza seus filhos com arruda e guiné, Vovó Chiquinha quando chega de Aruanda, cruza seus filhos com arruda e guiné. No terreiro firma ponto, nos seus filhos firma a fé. No terreiro firma ponto, nos seus filhos firma a fé.

Todos tirávamos os sapatos para confortavelmente sentarmos com os pés semiencobertos pela areia fina e refrescante, convidados a pousar as mãos entre as mãos de Vovó Chiquinha que sustentava um silêncio, um longo silêncio meditativo, antes de pronunciar com vagar: meu filho!

O ambiente reservado, apenas para a guia e o consultando, era amplo e onírico como um mar noturno. O tom intimista promovia uma condição muito propícia para percebermos tudo o que fazia daquele lugar um entremundos.

A chegada da terra mítica, Aruanda, era percebida na música da sua voz ao dizer "meu filho". Suas mãos desenhavam no ar, com delicadeza e precisão, um diálogo com meu passado, presente e futuro. Entre o que se via e não era explicitado, tudo seria dito baixinho nas minhas costas, nos gestos dos dedos estalando sobre minha cabeça, como numa transcendência para o que Vovó Chiquinha sempre me lembrava: a passagem, a nossa passagem pela terra. Receber o passe, tomar o passe, para garantir boa aventurança na jornada.

Ela parecia me conhecer tão bem, apesar de não entender o que ela me falava, mas isso era um detalhe porque gostava de ouvi-la. Era "a língua modificada por um forte coeficiente de desterritorialização". ${ }^{125}$ A mensagem dos pretos velhos num tipo de aliança pelo devir, entre as inúmeras possibilidades de entendermos devir, podemos compreendê-lo como a diferença na prática. A vizinhança em dimensões distintas se dava ali na insistência potente do re-vizinhar pela memória oral resgatada semanalmente na partilha dos desafios e sonhos com a vó preta de Aruanda. Ao refletir sobre os devires, na terceira parte de Metafisicas canibais, Viveiros de Castro apresenta o devir como a diferença molecular que é a multiplicidade.

${ }^{125}$ DELEUZE, Gilles e GUATTARI, Félix, op.cit. p. 25. 
O devir é uma relação real, molecular e intensiva que opera em um registro outro que o da racionalidade ainda apenas morfológica do estruturalismo. A síntese disjuntiva do devir não é possível segundo as regras dos jogos combinatórios das estruturas formais; ela opera nas regiões longe do equilíbrio habitadas pelas multiplicidades reais (DeLanda 2003:75). "O devir e a multiplicidade são uma só e mesma coisa" (D\&G. 1980:305). ${ }^{126}$

O antropólogo ressalta que nem toda aliança é um devir. Há a aliança extensiva, cultural e sociopolítica, e há a aliança intensiva, contranatural e cosmopolítica. Se a primeira distingue filiações, a segunda confunde espécies. No subúrbio carioca, posso dizer que a cosmopolítica confundia deuses, raças, tempos, línguas e narrativas. A voz de Vovó Chiquinha trazia palavras silenciadas no açoite das senzalas e, ali, se atualizavam no corpo da matriarca branca de origem portuguesa, no corpo da minha Tia Zoca.

Uma aliança entre mulheres, entre uma entidade e seu cavalo, termo que define a filha de santo; entre a alma da preta velha em contato com o corpo da mulher branca, outra dimensão das alianças múltiplas possíveis como reparação e hospitalidade.

Era um universo feminino que se valia do gestual das mãos, da força das vestimentas muito bem cuidadas e do sibilar nos ouvidos das costas numa reza, numa pausa para escutar algo etéreo, atemporal, como se conversassem e fizessem os recados chegar. Vez por outra, ficávamos sabendo que o cavalo estava cansado, que era preciso encerrar. Vez por outra, Vovó Chiquinha mandava recados para Tia Zoca, para quando pudéssemos partilhar.

Todos ali transitávamos por essa zona de indistinção, na qual o (re)vizinhar como associação múltipla não se dava numa filiação, mas numa aliança. Tia Zoca em nenhum momento permanecia presente, paradoxalmente seu corpo estava presente, tampouco partilhava algo que reforçasse uma fusão; a preta velha também não estava lá. Havia uma desterritorialização, uma “conexão parcial” nessa vizinhança extremada entre Tia Zoca e a entidade Vovó Chiquinha de Aruanda. Um aspecto imanente de ação, como observa Viveiros de Castro ao nos explicar o devir-jaguar: "quando um xamã ativa um devir-jaguar, ele não

\footnotetext{
${ }^{126}$ VIVEIROS DE CASTRO, op. cit. p. 184.
} 
'produz' um jaguar, tampouco se 'filia' à descendência dos jaguares; ele adota um jaguar; ele coopta um jaguar - ele estabelece uma aliança felina."

Ao contar ainda com a ajuda desse outro autor dual, no caso Viveiros de Castro citando Deleuze, para compreender como (re)vizinhar produz esse tipo de aliança no entre:

Dir-se-ia mais bem que uma zona de indistinção, de indiscernibilidade, de ambiguidade se estabelece entre dois termos, como se estivessem atingindo o ponto que procede imediatamente sua diferenciação respectiva: não uma similitude, mas um deslizamento, um avizinhamento extremo, uma contiguidade absoluta; não uma filiação natural, mas uma aliança contranatureza. (Deleuze 1993:200) ${ }^{127}$

Vizinhança como indistinção, como indeterminação e como multiplicidade. A coexistência de dialetos, gírias e sons que, reinventados, sustentavam um estrangeirismo acolhedor, no sentido de que a língua viva estava menos implicada em ser normativa, impositiva e conclusiva, mais aberta à escuta e a um tipo de deslocamento pela memória oral - uma literatura menor.

Naquele caso, de quem ouvia o silêncio ancestral e de quem estava disposto a escutarse e traduzir-se pela expressão dessa fala silenciosa, o que pudesse entender como acolhimento. O diálogo da coexistência produzia sua narrativa entre heterogêneos, no altar do quarto dos Santos, menos inserido num dogmatismo religioso, mais próximo de uma ação comunitária que selava entre aquele pequeno grupo uma possibilidade de uma participação antinatural pela relação de estados de intensidade.

A vida suburbana do Rio de Janeiro também sempre esteve associada ao caos. Digo também porque, neste texto, a palavra caos nos permite estabelecer uma correlação entre a Zona Norte carioca e a região central da Luz, em São Paulo: "o abrir-se, entreabrir-se no vazio, a profundidade insondável" que vimos ao apelarmos para Junito Brandão. São essas zonas de invisibilidade determinadas por estratégias de apagamento histórico e preenchidas por uma massa informe de todo o tipo de gente, que nos permite pensar no vazio anterior a criação; como

${ }^{127}$ VIVEIROS DE CASTRO, op. cit. p. 190. 
a comunidade de lugares vicários pensada por Agamben, "uma comunidade absolutamente irrepresentável".

No caso carioca, numa escala monumental pela escravidão e pelas marcas de abandono pós-abolicionista da população negra e periférica, essa vacância também permitia a aliança, pela via da desterritorialização, dos corpos que escapavam da organização binária dos sexos para o que nos devires podemos compreender como " $n$ ' sexos que se conectam com 'n espécies' no plano molecular: 'a sexualidade passa pelo devir-mulher do homem e pelo deviranimal do humano: emissão de partículas' (D. \& G. 1980:341)". ${ }^{128}$

Corpos também irrepresentáveis no sentido foucaultiano de escaparem do enquadramento e serem constantemente múltiplos em vários enredos de festa e religião, no melhor dos casos, ou, pela violência, substituíveis em série letal que reafirma a condição do negro como descarte.

No fio dessa sociabilidade múltipla na qual a rua é gozo e morte, é potência criativa e apagamento geral ao mesmo tempo, no subúrbio carioca essa vizinhança indistinta ganha a máxima evidência no carnaval. Esses mesmos corpos invisibilizados devolvem ao plano da ação, numa sucessão de agoras: o quilombo dos Palmares, os índios escravizados, a luta dos inconfidentes e o canto do trabalhador. ${ }^{129} \mathrm{O}$ carnaval como uma epidemia, um povoamento por contágio que permite toda sorte de "núpcias contranatureza". ${ }^{130}$

Acontecimento político porque faz do ato performativo algo capaz de nos liberar para toda a sorte de relações humanas e não humanas que se atualizam no cotidiano, no miúdo do dia e da noite, dos avizinhamentos extremos.

A sociabilidade múltipla que me permitiu esse livre trânsito povoado por entidades, personas e fantasias também provocou meu encontro com Exu no Candomblé. Levado pelo meu pai, cheguei num jardim de um terreno próximo a nossa casa na Abolição. E lá estava o “orixá do lado de fora"131 já em ação. O corpo viril, lascivo e ambíguo, a risada maldosa e desafiante. Oposto à plácida e doce figura paterna, que talvez tenha me apresentado, ali, um

\footnotetext{
${ }^{128}$ Idem, p. 188.

${ }^{129}$ Pequena homenagem ao samba imortalizado na voz de Clara Nunes: "Canto das três raças", de autoria de Mauro Duarte e Paulo Pinheiro.

${ }^{130}$ Id., ibid. p. 188.

${ }^{131}$ Disponível em: https://pt.wikipedia.org/wiki/Exu (orix\%C3\%A1). Acesso em: 22 Dez 2020
} 
certo tipo de masculinidade da rua, que não cabia nos lugares aparentes da família, mas que funcionava como extensão dele próprio em outro lugar.

Fiquei frente a frente com um homem branco muito suado, com a pele avermelhada. Ele era um colega de supletivo, amigo do meu pai, frequentava a nossa casa. Mas ali, vestia roupas brancas muito justas já nem tão limpas, estava descabelado, falava muito alto e dava largos tragos na garrafa de cachaça. Frenético, andava de um lado para o outro daquele terreiro, com o dorso da uma das mãos na cintura a sacudir os ombros em balanço, bebendo e limpando a boca com o braço, até que, entre todos, parou diante de mim e disse de maneira irascível: você é capaz?

Aproximou-se mais ainda, agachou-se para me encarar olhos nos olhos, no plano possível entre um homem adulto e um menino. Com o mesmo olhar feérico do vô Joaquim, chamou-me para o desafio. Levantou-se, caminhou e pisou com os pés descalços num monte de brasas. Ria muito e duvidava da minha coragem de aceitar o desafio de chegar perto dele e pisar lá, também. Depois voltou a andar pelo espaço e me desafiou novamente: pegou uma garrafa e quebrou-a com toda a força no chão, convidou-me para pisar nos cacos; duvidou que eu pisaria nos cacos. Meu pai não intercedeu em nenhum momento por mim, mas não me sentia traído. Ele insistia que eu pisasse nos cacos - finalmente aceitei o convite, muitos anos depois, nas ruas da Luz.

Pela Universidade de São Paulo, reinventamos a vizinhança em tempos estilhaçados, na qual todos continuamos a aprender a andar nos cacos da Cracolândia, exemplo do gueto contemporâneo, para comunicar, para coaparecer junto aos desejos de alguns daqueles que são os interlocutores diretos dos que só habitam o lado de fora, a vida nua, a miséria humana imposta pela arbitrariedade dos homens e que, mesmo assim, não perdem a dimensão do sonho, em algum nível do pior dos estados de consciência e condições de dor.

Pisar onde poucos paulistanos pisam: no fluxo. E, aqui, recordar que nossa última ação no território foi colaborar na produção do carnaval da Cracolândia, com adereços para o Blocolândia, no início de 2020. Porém, considero que a principal atividade realizada pelo Diversitas naquele pedaço foi a criação de uma árvore dos desejos, na festa junina de 2018. Como o carnaval, festa também. Oferecemos fitas coloridas aos homens, mulheres e 
adolescentes que transitavam no fluxo e na festa. Pedimos para que escrevessem seus sonhos, recados, compromissos, delírios e desejos.

Não teria como seguir para as considerações finais sem a partilha do que pudemos registrar a partir da criação livre desses homens e mulheres, representados e interpretados como deploráveis, demenciados, abjetos pelo establishment. Chumbados pela força policial que os confina e os ataca simultaneamente. Ali, naquela festa guerrilha, com todos os empecilhos para a vida fluir, escolheram, entre as cores, entre os galhos da árvore dos desejos, o que dizer e onde pendurar, onde (re)Vizinhar as múltiplas utopias:

1. Fita azul: "Transformação"

2. Fita rosa: "Quero ter autonomia da minha vida"

3. Fita laranja: "Relações cheias de afetos"

4. Fita verde: "Quero voltar logo para casa"

5. Fita verde: "Ser rico"

6. Fita rosa: "Abandonar o crack"

7. Fita rosa: "Justiça. Liberdade. União. Paz"

8. Fita azul: "Mãe, eu te amo"

9. Fita rosa: "Prosperidade, dinheiro, sucesso, objetivo e conquistas"

10. Fita pink: "Amar e ser amada"

11. Fita azul-clara: "Muita paz, fé, sabedoria e inteligência. Amém. Nos livrar dos vícios"

12. Fita amarela: "Vitor Hugo"

13. Fita vermelha: "Uma casa grande"

14. Fita azul: "Jesus chorou. Fé em Deus e + ele fará." Zic Ro Ro

15. Fita vermelha: "Ser rico"

16. Fita azul: "Que o preconceito acabe porque todos nascemos iguais = pelados e sem dentes"

17. Fita verde: "Quero desejar sabedoria e muita saúde a minha família"

18. Fita rosa: "Amar e ser amada"

19. Fita vermelha: "Se amar é viver, vivo porque eu amo você" Thayná

20. Fita amarela: "Eu quero voltar a rever meu filho"

21. Fita rosa: "Eu desejo estar com as minhas filhas Bianca e Suellei"

22. Fita azul-clara: "Que Deus ilumine os nossos caminhos" 
23. Fita azul-clara: "Família retaguarda"

24. Fita azul-clara: "Me libertar dessa prisão sem muros"

25. Fita vermelha: "Generosidade traz prosperidade. Mais amor por favor"

26. Fita azul-escura: "Paz e sabedoria, amor sério"

27. Fita verde: "paz e saúde"

28. Fita rosa-clara: "Fora corrupção"

29. Fita laranja: "Minha libertação"

30. Fita azul-clara: "Sair daqui"

31. Fita lilás: "+PIB na saúde, educação, cultura e habitação"

32. Fita rosa-clara: "Ela de volta pra mim"

33. Fita azul-clara: "Felicidade e a minha mãe e o meu pai"

34. Fita vermelha: "Quero que Deus me ajude a recuperar a minha filha"

35. Fita azul-escura: "Ganhar dinheiro, ficar rico, em fim... paz"

36. Fita rosa: "Sair da rua"

37. Fita azul-escura: "Que meu relacionamento vá para a vida toda." Jhullian e Caíque

38. Fita azul-escura: "Desejo a liberdade do sujeito em ser o que se é!"

39. Fita azul-escura: "Que meu relacionamento vá para a vida toda." Rosangela e Luan

40. Fita lilás: "Força, foco e fé. Recomeçar sempre!!!"

41. Fita rosa-clara: "Dinheiro, saúde, paz, emprego, sustentabilidade"

42. Fita rosa: "Coisas boas"

43. Fita laranja: "Que todos reconheçam Jesus como salvador e o Senhor como único Deus" 


\section{CONSIDERAÇÕES FINAIS}

Platão diz que o negativo do pensamento é o erro. Hegel diz que é a alienação.
Nietzsche diz que é a tolice. Espinosa diz que é a ignorância. Aí o Schopenhauer, com
a maior das propriedades, diz: nada disso; o maior adversário do pensamento é a
banalidade... a banalidade. A banalidade não permite que o pensamento pense! (...) O
mundo que é constituído para nós, a cidade que nos é dada, é inteiramente banal - nós
vivemos envolvidos na banalidade! Então, quando nós saímos do círculo da
banalidade e penetramos assim numa linha de pensamento, nós estamos arriscados a
ser atropelados lá fora. Porque é um mundo que se constitui como obstáculo - olha a
seriedade do que eu vou dizer - para a vida; é um obstáculo para a vida (...) A questão
dele é sempre a mesma - o aprisionamento da vida. ${ }^{132}$
Claudio Ulpiano

Abandonar o território no qual a palavra surge como plano de Estado, contida na sua origem por uma narrativa que insiste em fazer da história o seu castelo e da verificação o seu muro de arrimo. Experimentar outras zonas de vizinhança do dizer e nessas brechas evocar o texto no limite das urgências, como um abraço, uma ponte que não leva a lugar nenhum, mas expressa a potência da linguagem que é vida, que, viva, se expressa na imprecisão do aqui e agora para quem se dispõe ao exercício da escuta.

Diante dessas expectativas, o que busquei foi uma reflexão a partir da experiência e que, nesse momento do texto, reverbera menos pela especulação teórica e mais pela amizade à cidade e à universidade. A vizinhança entre as duas é a minha utopia. Porque Vizinhança, na condição de nome próprio, é a vizinhança entre as vizinhanças, é o devir vizinhança a reforçar o apelo do avizinhar, do re-vizinhar, do (re)vizinhar na multiplicidade que sustenta a coexistência de $n$ eixos de relações na produção partilhada do conhecimento.

A universidade da vizinhança compreende, abrange, inclui pela (des)semelhança, pela aproximação e pela amizade. Suscita a traição dos modelos à medida que deseduca os corpos marcados pela visão cristalizada da educação e descondiciona os desejos, sem adiantar nada do

132 
que se pode experimentar na abertura para ser-com, para com-parecer. Resta-nos a passagem e o compromisso ético de traçar as linhas de fuga que permitam o fim brutal da representação. Fica a hospitalidade, como a prática de quem experimenta o desabrigar-se voluntariamente, por acreditar que o acolhimento se dá nas conexões parciais, nas linhas borradas das bordas, no nosso caso, entre a Universidade de São Paulo e a região da Luz.

Dizer não ao que se revela como estrutural e acachapante é ter o gesto de estender um pano no chão da Rua Helvetia, em pleno fluxo, na festa do Dia das Crianças, e ver o grupo do Diversitas delicadamente arrumar os lápis de cera em pequenos vasilhames coloridos de forma atraente. Sentar, ali, naquele chão e experimentar um misto de constrangimento e dignidade no poder agir sem nenhuma certeza, a não ser a de que a violência é se privar da possibilidade de trânsito. O que aprendemos? O que trocamos? Quem ensina?

Duas situações atravessam essas reflexões e devem ser consideradas, e elas têm em comum o espaço em branco criado pelas atividades. A primeira se dá ainda no pano estendido na festa da Cracolândia: sentados sobre ele, numa perspectiva que nunca tínhamos experimentado, percebemos um quadrado alvo, radiante, radicalmente oposto à violência perturbadora do lugar. $\mathrm{O}$ que se deu tem a sutileza do que comunica pelos mínimos deslocamentos: os usuários, mesmo os mais delirantes, tinham o cuidado de deixar os chinelos fora do quadrado para, mesmo com os pés igualmente sujos, entrarem em outro lugar e (re)vizinhar num espaço de criação.

A segunda situação tem a ver com a Oficina de Palavras e Sonhos, no hotel social Zezinho 2, marcado pela prevalência de mulheres. Atividade à mesa, bastante adiantada, com muitas fotos, figuras recortadas, papéis coloridos. A usuária muito jovem e completamente alterada não conseguia participar, entrava e saía da sala inúmeras vezes, recusava o convite das psicólogas, até que no final cedeu e ingressou no grupo. Eu não conseguia entender o que ela falava, mas a mediadora nos ajudava num diálogo muito primário de "sim’ e "não".

-- Você quer escolher umas figuras?

-- ...Não!

-- Você quer escolher um desses papéis coloridos?

-- ...Não!

-- Você que escolher um lápis? 
-- ...Sim!

-- Você quer uma folha em branco?

-- ...Sim!

Reparei que além do forte cheiro de urina, seus pés descalços e muito machucados nos tornozelos com feridas aparentes se cruzaram no plano abaixo da mesa. Ao receber o papel e ajeitar-se na postura relaxada diante dele, a moça pousou as mãos na mesa e, com a direita, acariciou toda a folha em branco.

O pano, a folha e o uso que fizemos deles nessas duas situações me devolveram um entendimento de vizinhança como lugares de comunicação, no qual Borges já alertava para o sutil, o ínfimo deslocamento, quase imperceptível, que demanda todos os sentidos para perceber que o tempo é a substância de que somos feitos.

Esses lugares de comunicação que proporcionam "não mais lugares de fusão, mesmo que se passe de um a outro: eles são definidos e expostos pelo seu deslocamento. Assim, a comunicação da partilha seria esse deslocamento ele mesmo". ${ }^{133}$ Não tínhamos nada a dizer, mas buscávamos a coexistência possível no que é necessário enfatizar: a diversidade.

Re-vizinhar para manter a cidade como um canteiro de obras, na recorrente abertura desses panos e folhas em branco, que sempre serão outras folhas e outros panos a decalcar palavras, gemidos, queixas, risadas, memórias de cada paralelepípedo da velha cidade, como nos inspira Chico Buarque. Não como um portrait para enquadrar a cena, mas como uma foto polaroid que surge da impressão de luz e se apaga com o tempo.

Avizinhar-me no inacabamento que é o princípio, como alerta Nancy. Inacabamento sobretudo do passado, para que as histórias pululem sob o peso das tentativas de apagamento, com as nódoas do que guardou em revolta, mágoa, esquecimento e corpos desaparecidos. Os desdobramentos dessa pesquisa apontam para a continuidade dessa escuta vital e portanto impertinente. Extrair experiências que possam lidar com a mesma pergunta: do que se está falando?

Cada um precisa do ouvido do outro para saber do que se está falando. Linguagem composta de várias vozes como uma articulação de particularidades. O máximo que tentei foi

${ }^{133}$ NANCY, Jean-Luc, op. cit., p. 56. 
escrever palavras que sigam, que circulem e que afetem o sentido de passar, fazer passar, algo da experiência do que vimos naquele instante, no qual o corpo emprestou vida à cidade e dela ganhou mais desejo de viver a vizinhança como território da coexistência. 


\section{REFERÊNCIAS BIBLIOGRÁFICAS}

ANDRADE, Carlos Drummond de. Sentimento do Mundo. São Paulo: Cia das Letras, 2012.

AGAMBEN, Giorgio. Homo Sacer: o poder soberano e a vida nua I. 2. ed. Tradução de Henrique Burigo. Belo Horizonte: UFMG, 2010.

A comunidade que vem. Tradução de Cláudio Oliveira. Belo Horizonte:

Autêntica, 2013.

APPADURAI, Arjum. O medo do pequeno número: ensaio sobre a geografia da raiva. São Paulo: Iluminuras/Itaú Cultural, 2009.

ARENDT, Hannah. A promessa da política. Rio Janeiro: DIFEL, 2008.

AZEVEDO, Francisco Ferreira dos Santos. Dicionário analógico da língua portuguesa. 2. ed. Rio de Janeiro: Lexikon, 2010.

BATAILLE, Georges. O erotismo. Tradução Fernando Scheibe. 1. ed. Belo Horizonte: Autêntica, 2017.

BENJAMIN, Walter. Mágia e técnica, arte e política. In: Obras Escolhidas. 7. ed. Tradução de Sergio Paulo Rouanet. São Paulo: Brasiliense, 1994. v. I.

. Rua de mão única. In: Obras Escolhidas. 6. ed. Tradução de Rubens Rodrigues Torres Filho e José Carlos Martins Barbosa. São Paulo: Brasiliense, 2012. v. II.

. Passagens. Organização Willi Bolle; tradução do alemão de Irene Aron, tradução do francês de Cleonice Paes Barreto Mourão. Belo Horizonte: UFMG, 2018. v. 1.

BISHOP, Elisabeth. Poemas. 1.ed. Tradução: Horácio Costa. São Paulo: Companhia das Letras, 1990.

BONDER, Nilton. A Alma imoral. Rio de Janeiro. Rocco: 1998.

BORGES, Jorge Luis. Obras completas de Jorge Luis Borges. Vários tradutores. São Paulo: Globo, 1999. V. II.

BRANDÃO, Junito de Souza. Dicionário mítico-etimológico da mitologia grega. Petrópolis, RJ: Vozes, 1991. V. I. 
COETZEE, J. M. À espera dos bárbaros. Tradução de José Rubens Siqueira. São Paulo: Companhia das Letras, 2006.

DELEUZE, Gilles. Conversações. São Paulo: Ed. 34, 1992.

e GUATTARI, Félix. Kafka: por uma literatura menor. Tradução de Júlio Castañon Guimarães. Rio de Janeiro: Imago, 1977.

de Francisco Monge. Barcelona: Paidós, 1974.

El Anti Edipo Capitalismo y Esquizofrenia. Traducción . Mil platôs. 2. ed. Tradução de Ana Lúcia de Oliveira e Lúcia Cláudia Leão Suely Rolnik. São Paulo: Ed. 34, 2011. v. 2.

Derrida, Jacques. A universidade sem condição. Tradução de Evando Nascimento. São Paulo: Estação Liberdade, 2003.

. Anne Dufourmantelle convida Jacques Derrida a falar Da Hospitalidade. Tradução de Antonio Romane. São Paulo: Escuta, 2003.

FREIRE, Paulo. Pedagogia do oprimido. Rio de Janeiro/São Paulo: Paz e Terra, 2019.

FOUCAULT, Michel. O que é um autor? Tradução portuguesa de António Fernando Cascais e Edmundo Cordeiro. Lisboa: Passagens/Vega, s/d.

. As palavras e as coisas. 7. ed. Tradução de Salma Tannus Muchail. São Paulo: Martins Fontes, 1995.

GARCÍA CANCLINI, Néstor. O mundo inteiro como lugar estranho. Tradução de Larissa Fostinone Locoselli. São Paulo: Edusp, 2016.

HARAWAY, Donna Jeanne. Stay with the trouble. Duham and London.Duke University Press, 2016.

LEITE, Sebastião Uchoa. A espreita. São Paulo: Perspectiva, 2000. (Coleção Signos).

LEVI, Primo. A tabela periódica. Rio de Janeiro: Relume-Dumará, 1994.

.É isto um homem?. Rio de Janeiro: Rocco, 1988.

LISPECTOR, Clarice. A paixão segundo G.H. Rio de Janeiro: Rocco. 2009. 
LÖWY, Michel e SAYRE, Robert. Revolta e melancolia: o romantismo na contracorrente da modernidade. Tradução de Nair Fonseca. São Paulo: Boitempo, 2015.

KAFKA, Franz. A metamorfose. Tradução de Claudia Abeling. São Paulo, 2013.

MBEMBE, Achile. Necropolítica: biopoder, soberania, estado de exceção, política de morte. São Paulo: N-1, 2018.

MAFFESOLI, Michel. Elogio da razão sensivel. Tradução de Albert Christophe Migueis Stuckenbruck. Petrópolis: Vozes, 2005.

NANCY, Jean-Luc. A comunidade inoperada. Tradução de Soraya Guimarães Hoepfner. Rio de Janeiro: 7Letras, 2016.

NASSAR, Raduan. Lavoura arcaica. 3. ed. São Paulo: Companhia das Letras, 1997.

RULFO, Juan. 100 fotografias de Juan Rulfo. Tradução de Denise Bottmann e Gênese Andrade. São Paulo: Cosac Naify, 2010.

SAFATLE, Vladimir. Grande hotel abismo: por uma reconstrução da teoria do reconhecimento. São Paulo: WMF Martins Fontes, 2012. . O circuito dos afetos. São Paulo: Cosac Naify, 2015.

SANTOS, Boaventura de Sousa. Renovar a teoria crítica e reinventar a emancipação social. São Paulo: Boitempo, 2007.

SANTOS, Milton. A natureza do espaço: técnica e tempo, razão e emoção. São Paulo: Edusp, 2006.

TURNER, Victor. O processo ritual: estrutura e antiestrutura. Tradução de Nancy Campi de Castro. Petrópolis: Vozes, 1974.

e BRUNER, Edward M (Orgs.). The anthropology of experience. Illinois: University of Illinois Press, 1986.

ULPIANO, Claudio. Gilles Deleuze: a grande aventura do pensamento. Rio de Janeiro: Funemac Livros, 2013.

VERNANT, Jean-Pierre. Entre mito \& política. Tradução de Cristina Murachco. São Paulo: Edusp, 2001. 
VIVEIROS DE CASTRO, Eduardo. Metafísicas canibais. São Paulo: Cosac Naify e N-1 edições, 2015.

\section{Outras referências}

ACERVO CLAUDIO ULPIANO. Disponível em: https://acervoclaudioulpiano.wordpress.com/aulas-em-audio/ Acesso em: 22 Dez. 2020.

ALVES, Ygor. A Cracolândia como "Communitas"e o frade craqueiro. Publicado em: Ramminger, Tatiana \& Silva, Martinho (Organizadores). Mais substâncias para o trabalho em saúde com usuários de drogas. 1a Edição. Porto Alegre: Rede UNIDA, 2014. ${ }^{2}$ Manteremos a palavra "communitas" entre aspas conforme faz Victor Turner. Disponível em: https://www.academia.edu/12872751/A_Cracol\%C3\%A2ndia_como_Communitas_e_o_frade craqueiro. Acesso em: $22 \mathrm{dez} .2020$.

CANDEIAS, Ozualdo. Bocadolixocinema, 1976 https://youtu.be/SpQ0SKtVhXI Acesso em 22 Dez. 2020

DAWSEY, John C. Victor Turner e a antropologia da experiência in Caderno de Campo, v.13, n13, São Paulo, 2005. Disponível em:

http://www.revistas.usp.br/cadernosdecampo/article/view/50264, Acesso em 22 Dez. 2020

É DE LEI. Disponível em https://edelei.org/home/sobre-nos/ Acesso em: 22 Dez. 2020.

ESTUDO PRÁTICO. Disponível em: https://www.estudopratico.com.br/enzimas-funcoes-eclassificacao/. Acesso em: 22 Dez. 2020.

GOVERNO DO ESTADO DE SÃO PAULO. Disponível em : http://www.saopaulo.sp.gov.br/spnoticias/programa-recomeco-o-inicio-da-recuperacaocomeca-na-abordagem/. Acesso em: 22 dez. 2020.

. Disponível em

https://www.desenvolvimentosocial.sp.gov.br/a2sitebox/arquivos/documentos/1675.pdf, Acesso em: 22 dez. 2020

JORNAL DA USP. Disponível em: https://jornal.usp.br-/podcast/momento-cidade-14-porque-temos-tantas-casas-vazias-em-sao-paulo/ Acesso em: 22 Dez. 2020

KUBA, Ricardo e TRIMER, Daniel. SONHOS DA LUZ. Disponível em https://youtu.be/8jpNTE5s3AY. Acesso em: 22 Dez. 2020. 
MEDEIROS, Alexandre Boechat de. "Considerações sobre o prefixo RE” (UFRJ-

Departamento de Linguística e Filologia; Rio de Janeiro, RJ; 21941-901) in Alfa, v. 56, n. 2, São Paulo, 2010. p. 583-610. Acesso em: 22 Dez. 2020

PARRA, Regina. Um perigo e uma chance. Disponível em http://www.reginaparra.com.br/umperigo-e-uma-chance. Acesso em: 22 dez. 2020.

PLATAFORMA BRASILEIRA DE POLÍTICAS DE DROGAS. Disponível em: https://pbpd.org.br/publicacao/pesquisa-sobre-o-programa-de-bracos-abertos/ Acesso em: 22 Dez. 2020

PONTE. Disponível em https://ponte.org/pesquisa-na-cracolandia-mostra-maioria-negra-enumero-questionavel-do-mercado-do-crack/. Acesso em: 22 Dez. 2020.

PREFEITURA DE SÃO PAULO. Disponível em: https://gestaourbana.prefeitura.sp.gov.br/wp-content/uploads/2018/02/QA-PI.pdf . Acesso em: 22 Dez. 2020.

RUI, Taniele C. Corpos Abjetos: etonografia em cenários de uso e comércio de crack. Campinas. IFCH/Unicamp. Tese de Doutorado em Antropologia Social, 2012:190. Acesso em 22 Dez. 2020 
Anexo

Imagens da Vizinhança na Luz 


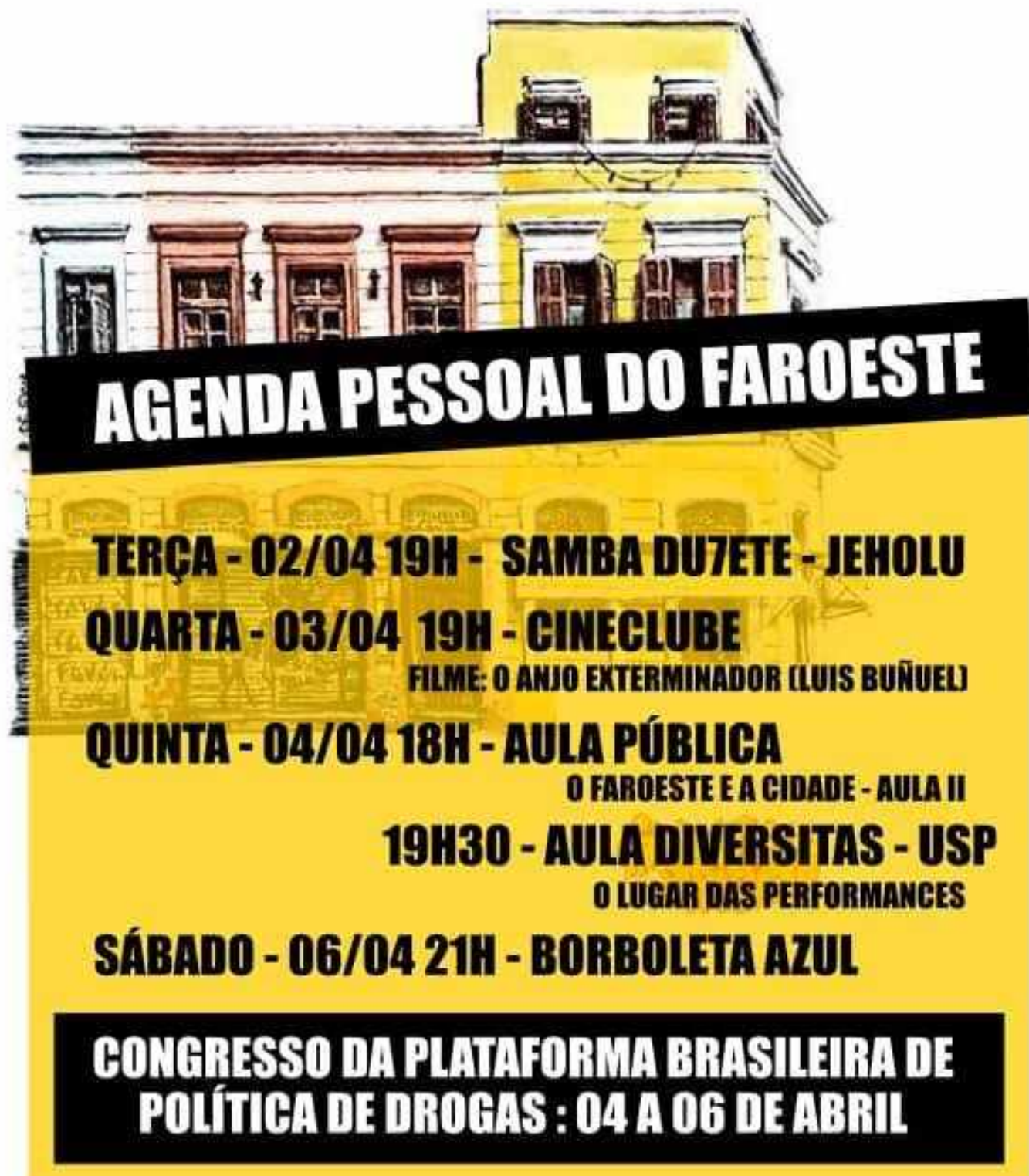

realização

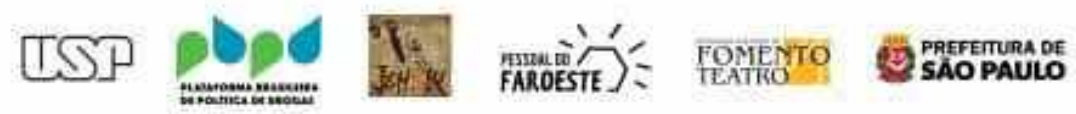




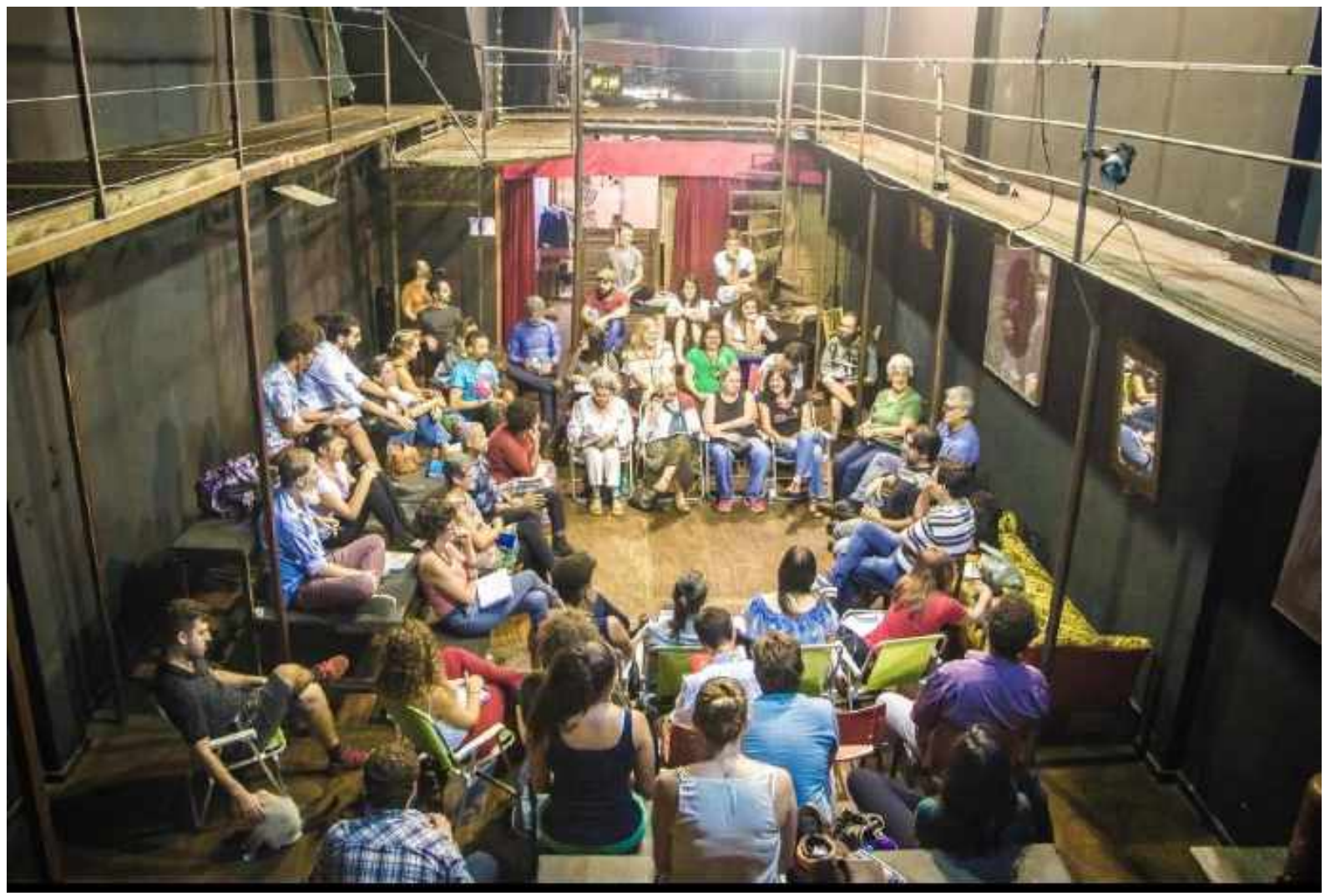

Aula da pós-graduação do Diversitas no Teatro da Cia. do Pessoal do Faroeste, em 2018 


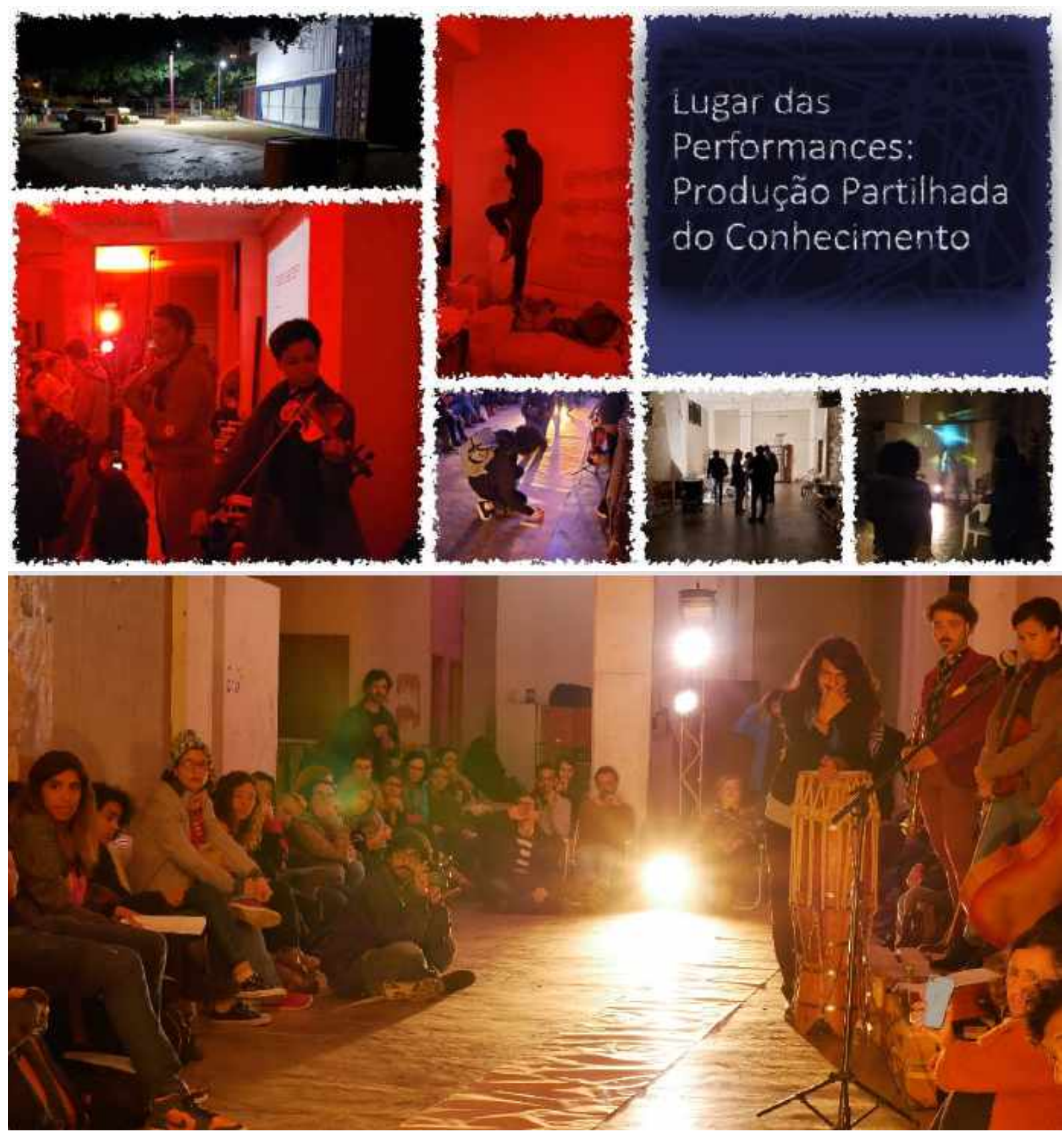

Cena 1. A disciplina ativista $(\mathrm{Re})$ sensibilização dos corpos e (Re)conhecimento do terriório. 


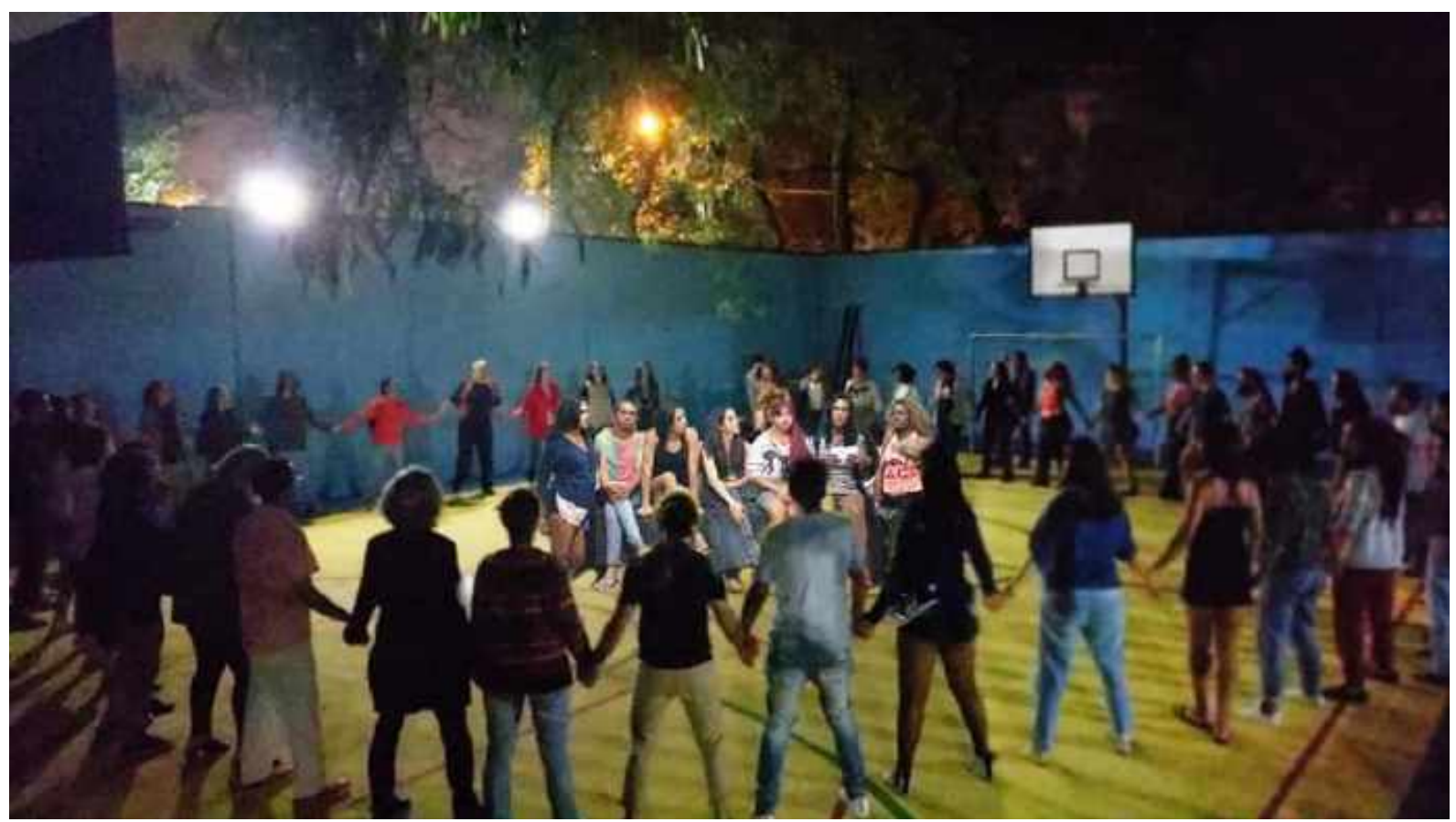

Disciplina Lugar das Performances. Cena 9. Trans-Cidades: Diversidades na Casa Florescer, 2019 


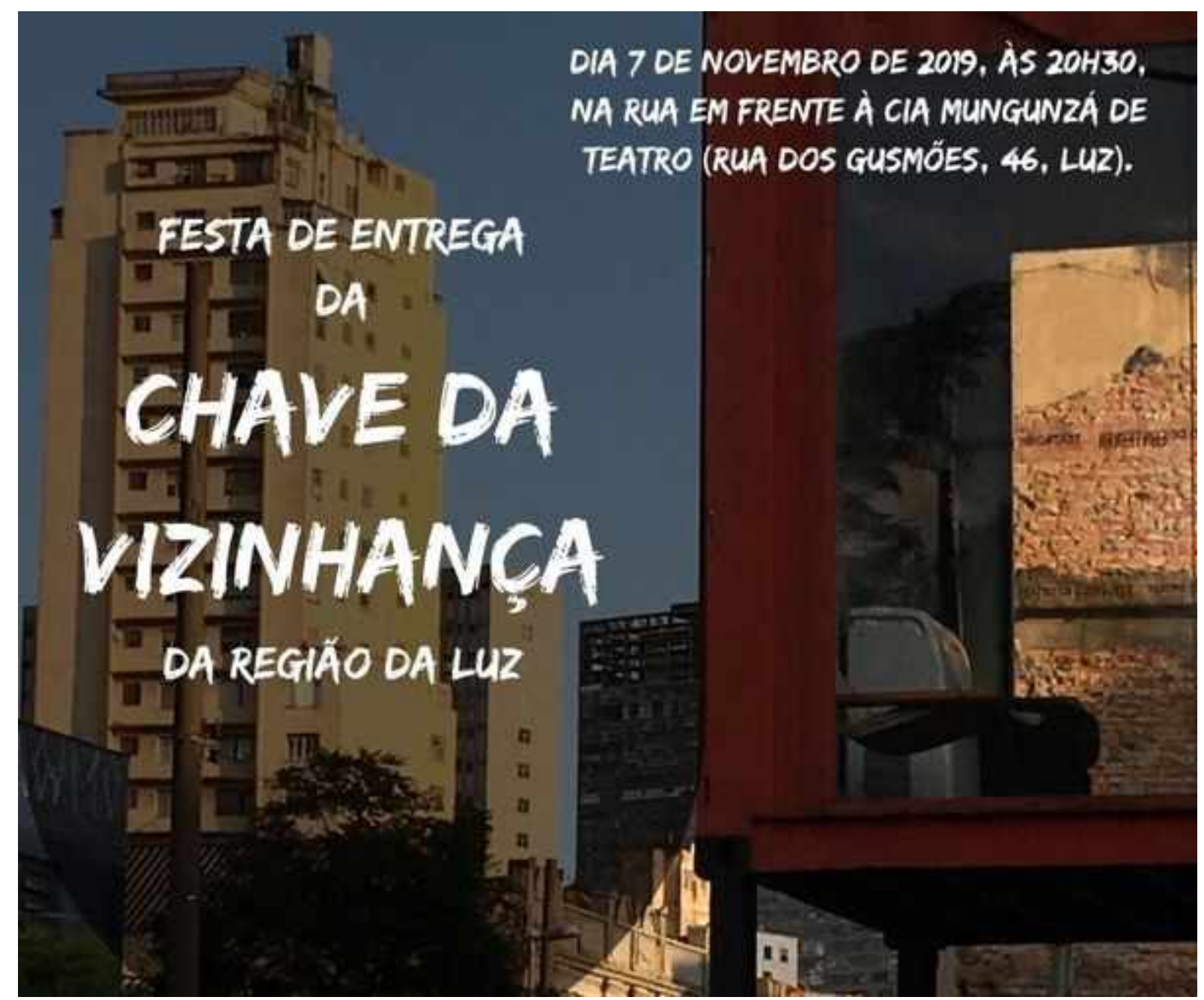

Cena 10. A vizinhança, 2019 


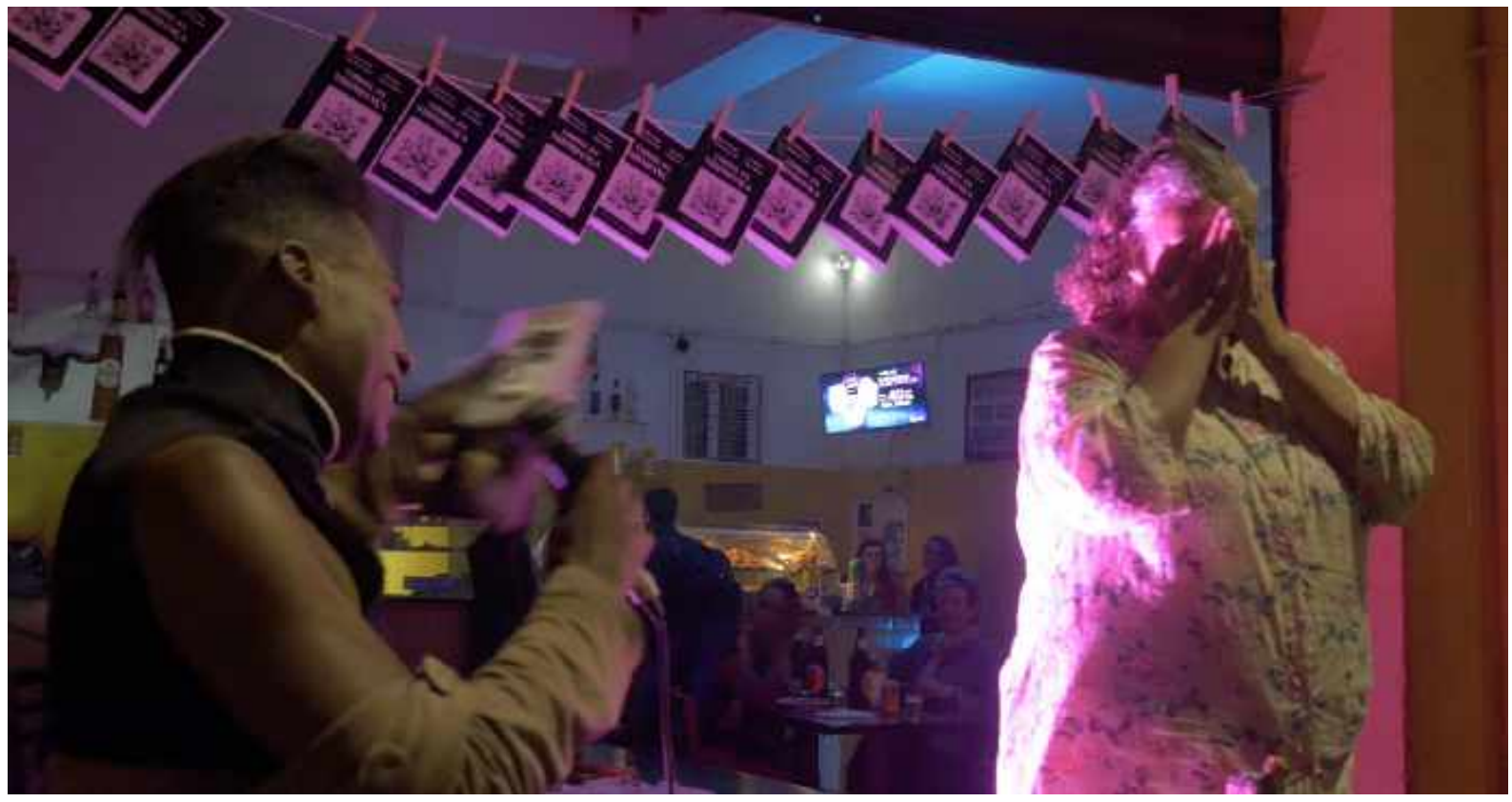

Cena 10. Joh Bintecourt entrega a chave da vizinhança para Carmen Lopes, 2019 


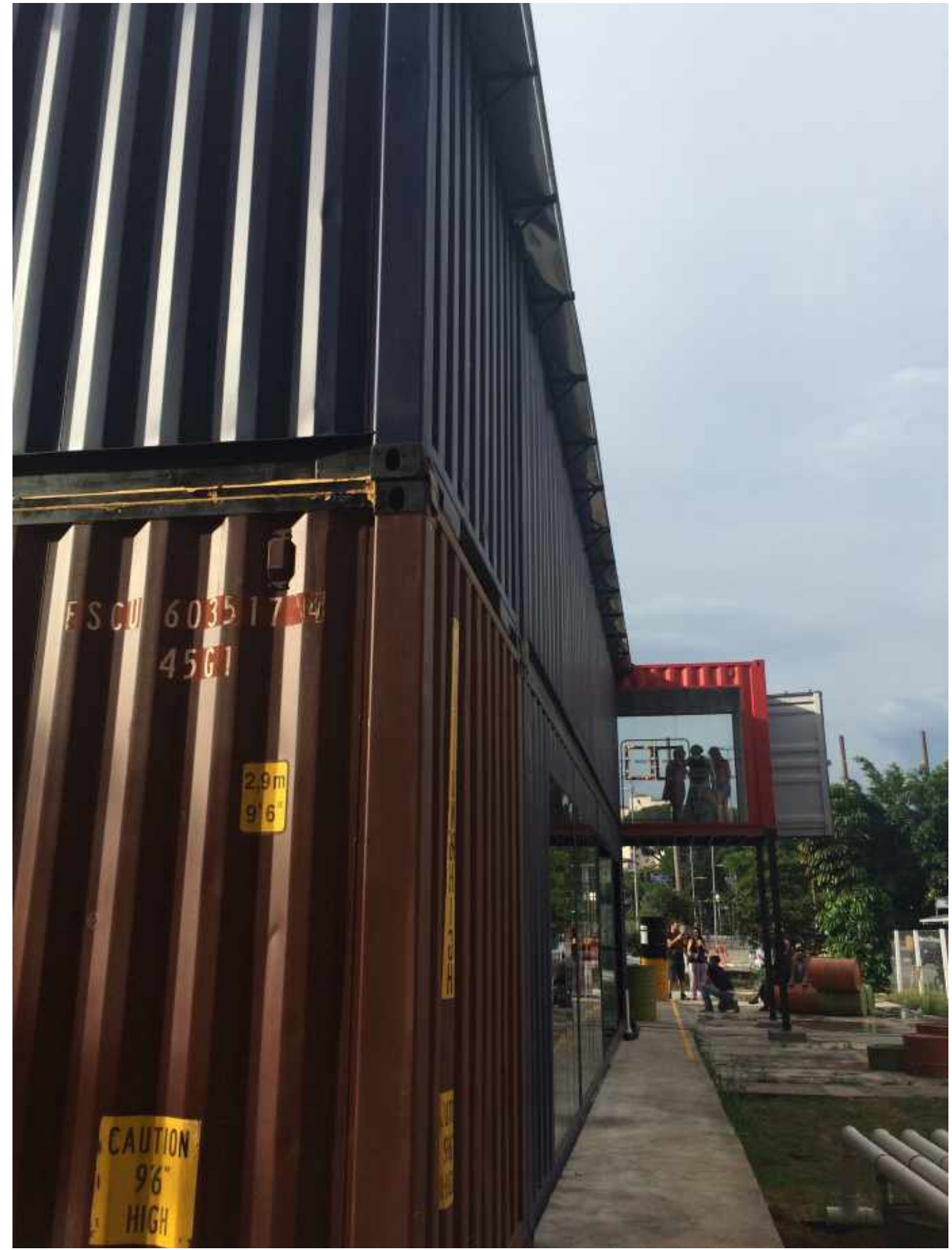

Teatro de Contêiner da Cia. Mungunzá 


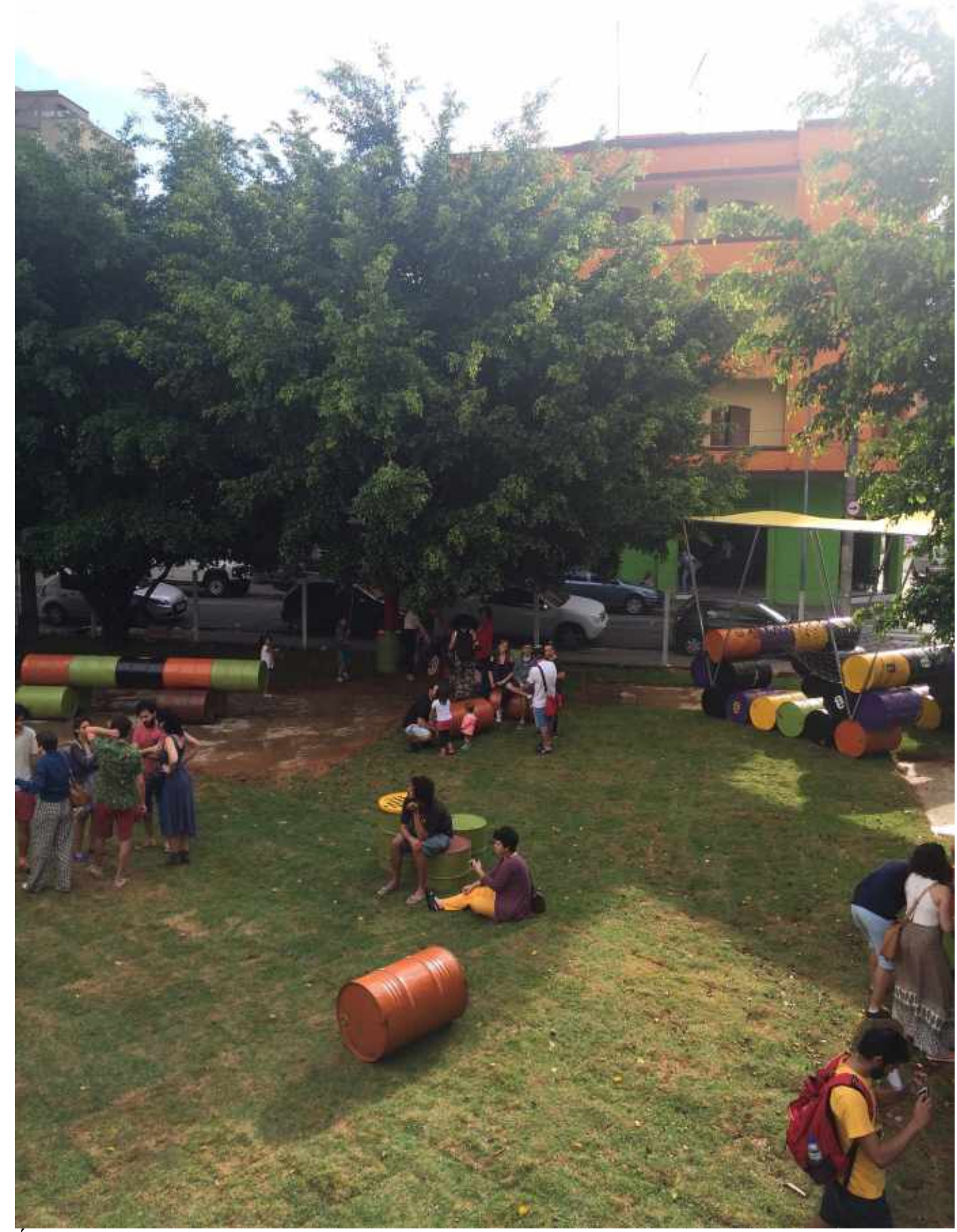

Área de convivência do Teatro de Contêiner, 2018 


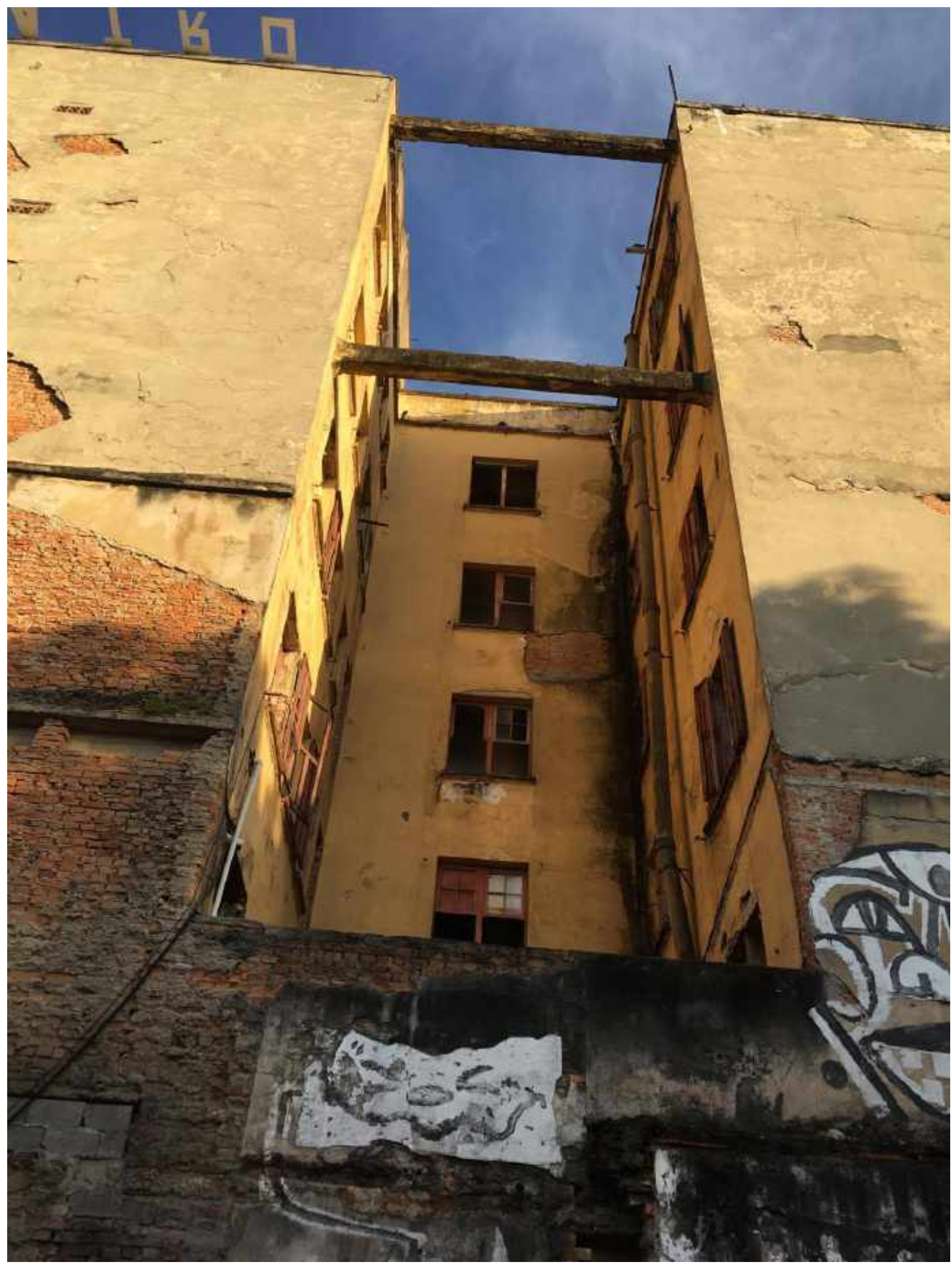

Prédio desocupado junto ao Teatro de Contêiner, 2018 


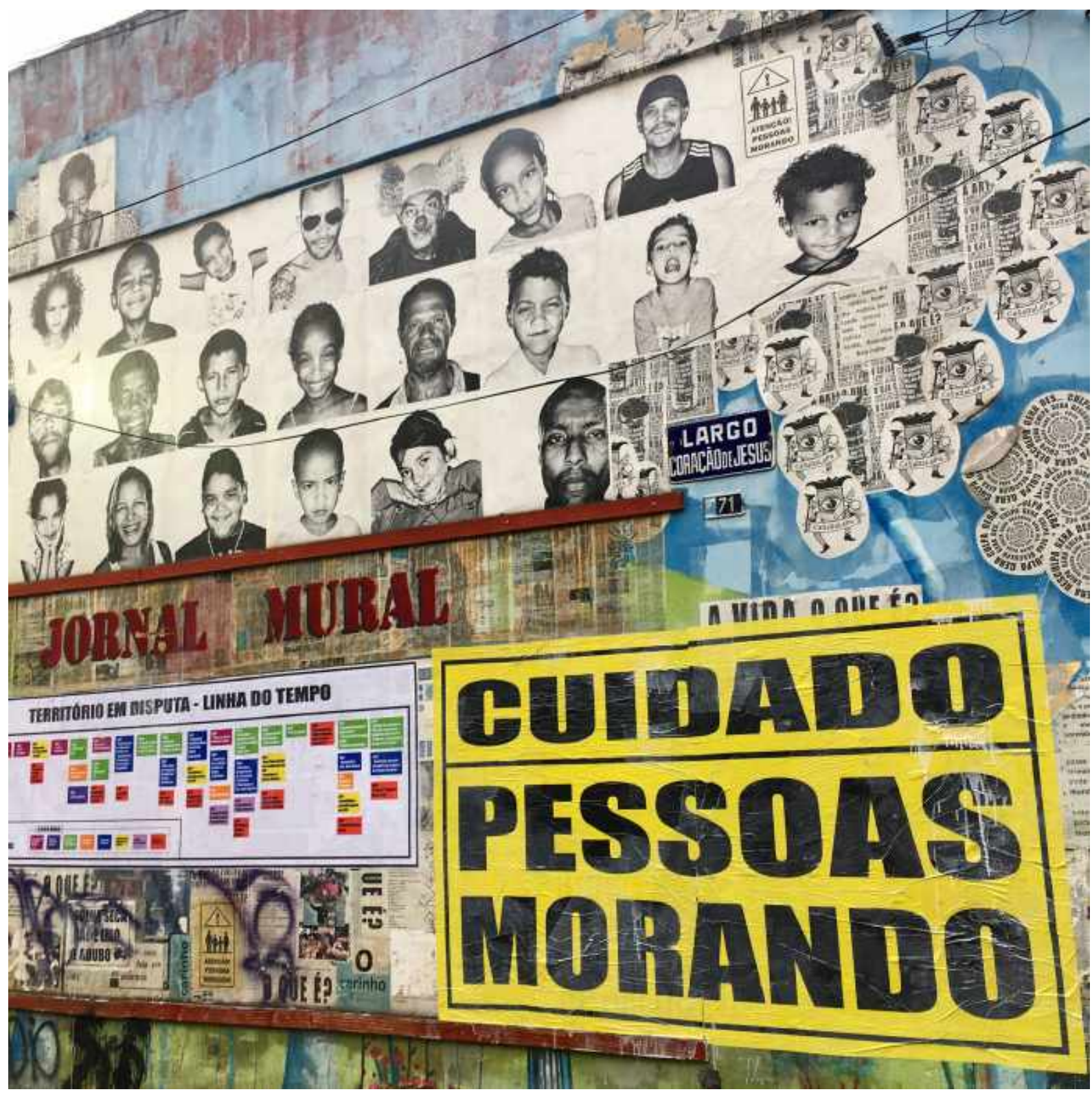

Protesto contra demolição dos sobrados e a remoção das famílias residentes da Cracolândia 


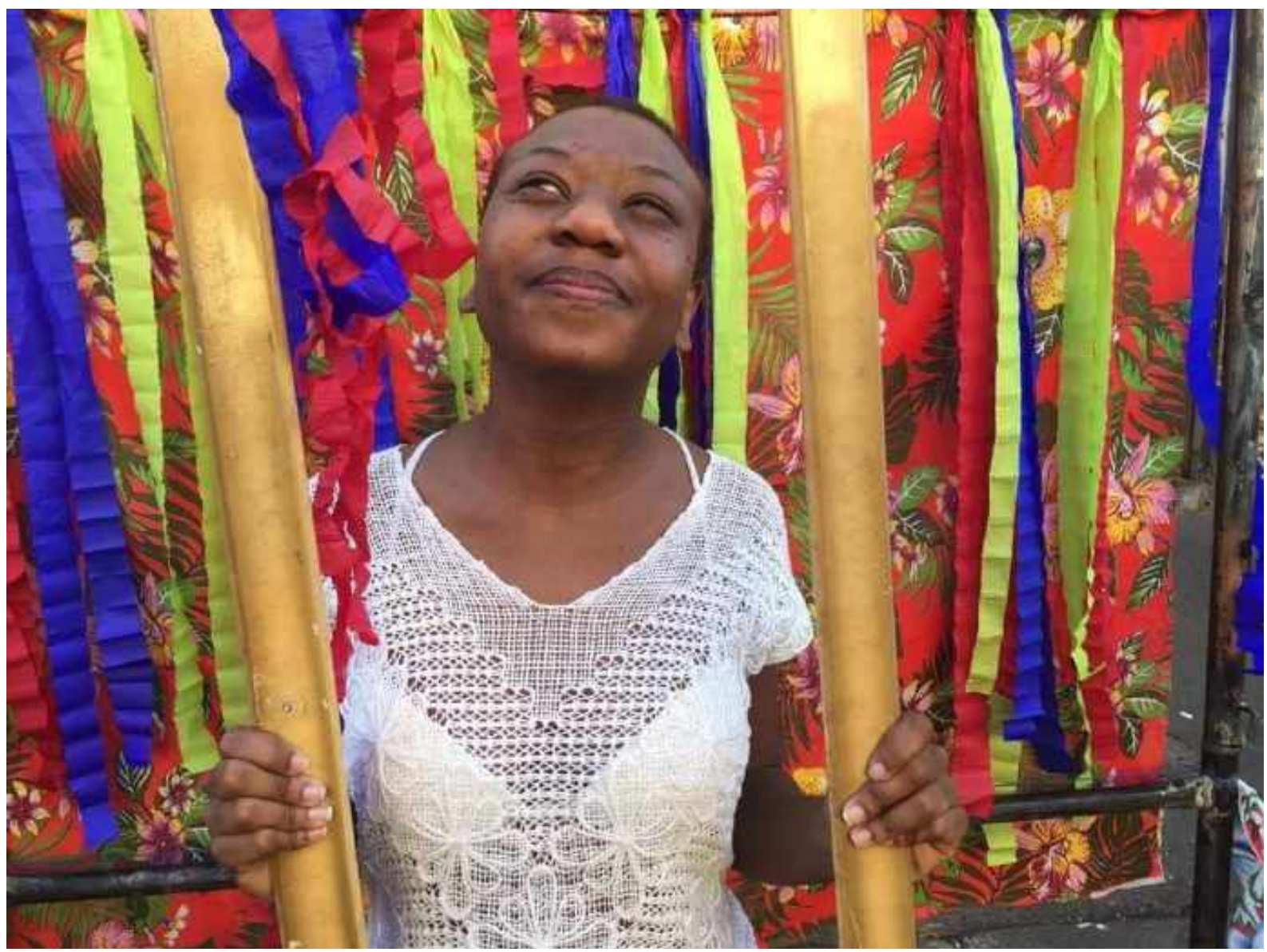

Ninguém nasce com uma mamadeira de crack. Festa junina do fluxo na rua Helvétia, 2018 